Juliana Braga Costa

\title{
ver não é só ver
}

dois estudos a partir de Flavio Motta

Dissertação apresentada à Faculdade de Arquitetura e Urbanismo como requisito para a obtenção do título de mestre.

área de concentração História e Fundamentos da Arquitetura e do Urbanismo

orientador

Prof. Dr. José Tavares Correia de Lira

São Paulo

2010

EXEMPLAR REVISADO E ALTERADO EM RELAÇÃO À VERSÃO ORIGINAL, SOB RESPONSABILIDADE DO AUTOR E ANUÊNCIA DO ORIENTADOR. O original se encontra disponível na sede do programa. São Paulo 29 de julho de 2011 
Autorizo a reprodução e divulgação total ou parcial deste trabalho, por qualquer meio convencional ou eletrônico, para fins de estudo e pesquisa, desde que citada a fonte.

e-mail: juliana.brac@gmail.com

Costa, Juliana Braga

C837v Ver não é só ver: dois estudos a partir de Flavio Motta / Juliana Braga Costa. --São Paulo, 2010.

250 p. : il.

Dissertação (Mestrado - Área de Concentração: História e Fundamentos da Arquitetura e do Urbanismo) - FAUUSP. Orientador: José Tavares Correia de Lira

1.Arquitetura (Crítica) 2. Exposições internacionais

3.Motta, Flávio Lichtenfels, 1923- I.Título

CDU 72.072.3 
para Fernando, Beatriz e João.

para Bernadete Braga, que não viu esse trabalho chegar ao fim. 



\section{resumo}

A dissertação trata das relações entre o campo intelectual da arquitetura e a atividade de projeto, na tentativa de reconhecer aproximações entre os projetos culturais, estéticos e políticos de vanguarda e a prática profissional. Nosso foco especifico é a interlocução de Flavio Motta com o meio arquitetônico em São Paulo, através de sua atividade crítica, da sua produção intelectual, do ensino de história da arte e das colaborações diretas que desenvolveu com alguns arquitetos. Partimos de uma breve apresentação de sua trajetória, sobretudo sua atuação como professor no MASP, no Curso de Formação de Professores de Desenho da FAAP e na FAU-USP. A partir daí, desenvolvemos dois estudos específicos: o primeiro se detém no texto que Motta escreveu como apresentação do número especial sobre o Brasil para a revista italiana Zodiac, em 1960; o segundo tem como foco o plano de atividades que ele propôs para o Pavilhão do Brasil em Osaka, na equipe vencedora do concurso, coordenada pelo arquiteto Paulo Mendes da Rocha, em 1970.

palavras-chave: Flavio Motta, revista Zodiac, Pavilhão de Osaka, FAU-USP, crítica de arquitetura, revistas especializadas.

\section{abstract}

This essay addresses the relationships between the intellectual field of architecture and its design activities, in the attempt to recognize connections among cultural, aesthetics and political avantgarde projects, with professional practices. Our specific focus is the exchanges between Flavio Motta's work and the architectural environment of São Paulo, throughout his critical activity, as a professor of Art History, and his direct work with some architects. Primarily we begin with a brief presentation of Flavio Motta's path, stressing in his teaching activities at the MASP (São Paulo Art Museum), and as a professor at both Universities FAAP and FAU-USP. From there we develop two specific surveys: the first is centered in the introduction text that Motta wrote for the Zodiac Magazine's special issue about Brazilian Architecture in 1960; the second focuses in the exhibition plan that he conceived for the Brazilian Pavilion project to the Osaka's International Exhibition in 1970, which project was design by the architect Paulo Mendes da Rocha.

Key words: Flavio Motta, Zodiac Magazine, Osaka Pavillion, FAU-USP, architecture critic, specialized magazines. 


\section{agradecimentos}

Agradeço a FAPESP, pela concessão da bolsa que tornou possível a realização dessa pesquisa; ao meu orientador José Lira, pela confiança depositada nesses anos de convivência e por sua imensa contribuição ao longo de todo o processo; aos membros a banca de qualificação Ana Maria Belluzzo e Renato Sobral Anelli, por seu interesse e leitura cuidadosa, pelas sugestões e questões levantadas.

Agradeço muito especialmente ao Flavio Motta, por me acolher de modo tão afetuoso. Nosso convívio certamente foi a experiência mais proveitosa desta pesquisa, ainda que na maior parte das vezes os assuntos do trabalho nem sequer surgissem em nossas conversas. A oportunidade de conviver com Flavio vai além de qualquer interesse específico na realização dessa

dissertação. Agradeço também a todos em sua casa que também me receberam generosamente durante essas visitas, especialmente Gule e Paula Motta.

ao Paulo Mendes da Rocha, pela gentileza e disponibilidade com que me recebeu em seu escritório durante a pesquisa, e pela generosidade com que disponibilizou um material muito precioso de seu acervo. Agradeço também a Dulcinéia, pelo auxílio com a organização e reprodução desse material durante essas visitas.

Ao Julio Katinsky, agradeço pelo depoimento fornecido a este trabalho, e além disso, pelas muitas conversas proveitosas que tivemos durante a Iniciação Científica. Ainda que não tenha nenhuma relação direta, certamente muito deste trabalho tem como referência a nossa convivência na graduação da FAU.

Ao Angelo Bucci, por seu incentivo à realização do mestrado e por compartilhar comigo seu projeto de trabalho ao longo dos últimos anos. A ele e João Paulo Meirelles de Faria, agradeço pela convivência agradável e produtiva no spbr. E também ao Ciro Miguel, amigo e parceiro de trabalho desde a graduação, que nos recebeu em sua casa durante pesquisa na Columbia.

Entre muitas pessoas que contribuíram diretamente na pesquisa, agradeço a três arquitetos que foram alunos das primeiras turmas da FAUUSP: Edoardo Rosso, pela revisão da tradução do italiano do artigo da Zodiac, Domingos Theodoro por fornecer generosamente seus souvenires da visita que realizou à Expo70, e a João Xavier, pelas fotos de Flavio Motta em aula e registros das atividades na FAU em 1958.

Além deles, uma turma de amigos contribuiu de diferentes maneiras para a realização dessa dissertação: Carolina Gimenez, João Yamamoto e Paula Dedecca, por sua ajuda com as imagens na etapa de finalização do trabalho; Eduardo Pompeu, que generosamente me forneceu desenhos em CAD do Pavilhão; Felipe Contier pela entrevista com Sergio Ferro; Luciana Ferrara, que dividiu comigo momentos importantes desse processo; e também os amigos do grupo de orientandos de José Lira - Paula Dedecca, Diego Bis, Clévio Rebelo, 
Mariana Guardani, Luisa Amoroso - por sua contribuição nas discussões da pesquisa e leituras realizadas ao longo do trabalho.

Agradeço também aos professores que me receberam como monitora PAE durante 3 semestres durante a realização deste trabalho: Alvaro Puntoni, Antonio Carlos Barossi, Helena Ayoub, Milton Braga, Angelo Bucci e Alexandre Delijaicov. Junto com os amigos José Paulo Gouvêa, Catherine Otondo e Marina Grinover, fizeram com que a monitoria na graduação se tornasse uma experiência decisiva durante esse período.

A Catherine Otondo, um agradecimento especial: foi ela quem me mostrou pela primeira vez a exposição do pavilhão de Osaka, e contribuiu para que novos caminhos fossem abertos no trabalho. Cathe também me levou ao escritório de Paulo Mendes da Rocha e compartilhou comigo muitas questões, que certamente convergem em nossas pesquisas. Espero ter a oportunidade de retomar esse diálogo em possíveis desdobramentos de nossos trabalhos. Aos funcionários das Bibliotecas da FAUUSP, especialmente Regina, Rejane e Dina, e a Isa da Secretaria da FAU-Maranhão. A Nice, do Departamento de História, por sua ajuda com os Programas de Curso.

A Paula Gabbai, por seu empenho e empolgação na encadernação deste volume. Aos meus pais Beatriz e Fernando, pelo apoio e incentivo constante. E especialmente ao João, que dividiu comigo mais esta aventura. 



\section{sumário}

$\begin{array}{ll}\text { introdução } & 11\end{array}$

1. Flavio Motta, entre a arte e o ensino $\quad 19$

1.1. Do modernismo ao moderno, da arte à arquitetura 20

1.2. O início pela pintura $\quad 29$

1.3. Anos de formação: educação e arte - da USP ao MASP 35

1.4. O ensino como ofício: a história da arte na FAUUSP 56

2. do cânone a Zodiac $\quad 83$

2.1. A revista Zodiac e o Rapporto Brasile 84

2.2. A recepção internacional da arquitetura brasileira 92

2.3. A crítica dos anos $50 \quad 98$

2.4. Introduzione al Brasile na revista Zodiac 106

3. o pavilhão de Osaka, feito até de arquitetura 119

3.1. A tradição dos pavilhões brasileiros nas exposições universais 119

3.2. A Expo 70 e o concurso para o Pavilhão do Brasil 124

3.3. O projeto vencedor, empenho em ir além 144

3.4. A exposição de Flavio Motta para o Pavilhão 168

considerações finais $\quad 185$

$\begin{array}{ll}\text { bibliografia } & 191\end{array}$

lista das imagens $\quad 199$

anexos

1. Tradução do artigo Introdução ao Brasil 201

2. Painéis da exposição de Flavio Motta no Pavilhão de Osaka 209

3. Documentação da obra do Pavilhão de Osaka 233 


\section{“[...] ver não é só ver,}

é preciso andar, relacionar e, inclusive, saber chegar. A gente vê também com os acontecimentos. E tenho a impressão de que a gente vê também com os olhos da história e da sociedade, por essas dimensões do tempo existentes na capacidade social das transformações."

Flavio Motta, A casa, 1973. 


\section{introdução}

Este trabalho pretende discutir algumas aproximações entre o campo intelectual e a atividade de projeto, tendo como foco específico a contribuição de Flavio Motta e sua interlocução com os arquitetos em São Paulo. Trata-se de reconhecer as relações entre os projetos culturais, estéticos e políticos de vanguarda e a prática da arquitetura, através da crítica, da produção intelectual, do ensino e das colaborações diretas que Flavio Motta estabeleceu com os arquitetos, especialmente aqueles próximos de Vilanova Artigas e da FAUUSP durante a década de 60.

Partimos, num primeiro momento dessa pesquisa, de um entendimento de que através da atividade crítica era possível reconhecer as convergências e contribuições mútuas traçadas entre a atividade intelectual e a prática profissional. Nosso pressuposto inicial era o de que a crítica, ao mesmo tempo em que cumpria um papel específico na atualização das coordenadas de projeto, também se articulava a plataformas estéticas, culturais e ideológicas relevantes em cada momento, repercutindo um embate peculiar com as dimensões técnicas e construtivas da arquitetura. Nesse sentido, um estudo que tratasse da interlocução entre a atividade crítica e a prática da arquitetura nos permitiria contribuir para estudos mais amplos acerca das intersecções entre o campo cultural da vanguarda e a produção de arquitetura em São Paulo nas décadas seguintes às primeiras investidas do modernismo na cidade.

Investigamos, de início, algumas trajetórias individuais de críticos de arte que haviam se dedicado a comentar a arquitetura contemporânea, procurando entender de que modo a produção intelectual gradualmente foi se aproximando dos problemas próprios da arquitetura de seu tempo, passando a contribuir na atividade profissional. Nosso interesse era particularmente na produção arquitetônica em São Paulo a partir da década de 60, aquela que é constantemente identificada pela crítica contemporânea como "escola paulista"; em outras palavras, pretendíamos reconhecer através da crítica algumas aproximações entre 0 
modernismo e a arquitetura, especialmente na produção que se desenvolveu em torno de Vilanova Artigas em São Paulo.

Quando se trata deste grupo é comum o debate acerca da própria existência de uma "escola", se esse movimento efetivamente estava articulado e conscientemente pretendia ocupar uma posição de liderança da arquitetura brasileira, procurando reconhecer em seu discurso se havia alguma contraposição ao grupo carioca, e compreender suas diferenças. Proliferam os debates que pretendem classificar e rastrear as filiações deste movimento nas tendências contemporâneas, especialmente as aproximações entre este grupo e o movimento brutalista.

Não é nossa intenção, entretanto, reafirmar os discursos que pretendem classificar a produção desse período nesta ou naquela tendência, nem reforçar as oposições entre uma escola carioca, de um lado vista como expressão institucional e de outro como formalista ou desvinculada da realidade social, e outra paulista, mais ligada as técnicas construtivas e aos processos de modernização do país. Nossa intenção foi a de contribuir para que se abram novas possibilidades de entendimento, que escapem às classificações a priori e permitam abordagens mais complexas, que antes de procurar enquadrar a produção de nosso movimento moderno em definições pré-estabelecidas, permitam perceber singularidades nas trajetórias e nas obras que enriqueçam as possibilidades de apreensão histórica do período.

Nesse sentido, o recorte a partir da interlocução entre Flavio Motta e os arquitetos em São Paulo permite discutir essas questões, em grande parte devido à multiplicidade de frentes de atuação que caracterizam sua trajetória até os dias de hoje. Sua contribuição para o curso da FAU-USP, para os debates no campo arquitetônico paulista, para o ensino e a arte, reafirmam as possibilidades de diálogo e as influências mútuas entre as esferas da crítica e teoria e o campo da prática profissional.

No caso de Flavio Motta, entretanto, essa articulação entre a atividade do intelectual e o campo da prática tem a dimensão de uma situação muito particular, e por isso mesmo muito mais intrigante do que em outros casos, pois Flavio Motta de fato intervém diretamente no campo profissional e, como pretendemos discutir nesse trabalho, através da dupla atividade de ensino dos arquitetos e sua colaboração direta em equipes de projeto, ao mesmo tempo em que mantém uma produção crítica e teórica relevante nas atualizações dos debates e diálogos com a prática. Nenhum dos outros intelectuais e críticos que estudamos brevemente neste trabalho atuou nesta dupla via da prática e da crítica: Geraldo Ferraz e Lourival Gomes machado, por exemplo, por mais que tenham provocado diversos rebatimentos no campo profissional através de sua contribuição teórica, sempre se mantiveram estritamente na posição do observador externo. É claro que, ao mesmo tempo, a produção escrita de Flavio Motta, especialmente se considerarmos seus textos de crítica da arquitetura contemporânea, nunca 
alcançou a regularidade e sistemática dos outros críticos mencionados, mas é justamente nos múltiplos modos de intervir no campo profissional que reside o interesse em estudar esta relação através de sua obra.

Ainda assim, as referências sobre seu trabalho são escassas e nenhuma abarca o conjunto de sua produção. 0 que se pode encontrar são alguns registros desconexos, poucos documentos e depoimentos, menções soltas em trabalhos que tratam da cultura em São Paulo ou que dizem respeito à sua produção como artista', que quando entremeados, revelam seu prestígio entre os alunos, companheiros de trabalho, intelectuais, arquitetos e artistas contemporâneos, e nos dão pistas de sua contribuição determinante no campo cultural e arquitetônico paulista e especialmente na FAU-USP². Exceto por estes curtos testemunhos, alguém que pretenda estudar a obra de Flavio Motta tem disponível, como ponto de partida, apenas o conjunto de trabalhos publicados e as menções sobre essa produção que podem ser encontradas em algumas enciclopédias e dicionários de artes plásticas, que constantemente recaem em pequenas incorreções, repetições e incompatibilidades.

De certo modo, compensamos a escassez dos registros documentais realizando encontros com Flavio Motta durante todo o processo da pesquisa. Certamente esses encontros, em alguns momentos quinzenais, contribuíram para muito da reflexão que apresentamos neste trabalho, no entanto, seus registros não são lineares e sistemáticos, reflexo da dinâmica estabelecida pelo próprio interlocutor. Além disso, sabemos que partir dos depoimentos de Flavio Motta como fonte de pesquisa traz uma parcela de risco, própria dos trabalhos que se valem da história oral como método de pesquisa. Como alerta Michael Hall, esse depoimentos "mostram menos a experiência direta dos informantes do que o resultado do trabalho que a memória faz com essa experiência"3, e a memória "é sempre uma reelaboração". E neste caso, temos uma dupla armadilha: não só o próprio risco de depender das memórias de Flavio Motta, mas também a forma de registro dos encontros, já que Flavio não consentiu que os depoimentos fossem gravados. Assim, documentamos nossas conversas num diário de visitas, e sabemos que aquilo que se anota no diário também é o resultado de um pensamento seletivo, ainda que involuntário.

1 Incluem-se nessa lista os catálogos de exposições coletivas e individuais, referências a sua participação em salões, etc. Além disso, entre as pequenas notas biográficas publicadas, podemos mencionar o Dicionário das artes plásticas no Brasil, de Roberto Pontual, Ed. Civilização Brasileira, 1969.

2 Um desses exemplos é a sua participação na banca examinadora do concurso de Titulação de Vilanova Artigas; ou então a publicação de um caderno especial sobre Flavio Motta na revista Caramelo n 6 , que trazia conjunto de depoimentos de professores e ex-alunos a respeito de seu trabalho.

3 Michael Hall, "História oral: os riscos da inocência" in O direito à memória. DPH, São Paulo, 1992. pp.157-160. 
Nesse sentido, procuramos manter uma certa cautela com relação ao uso desses depoimentos, até mesmo em função da delicadeza de nossos registros e da dificuldade em separar as lembranças e experiências de cunho mais pessoal, daquelas que efetivamente poderiam ser utilizadas como documento. Tentamos manter o distanciamento crítico necessário a qualquer estudo, e neste caso, procuramos estabelecer esse distanciamento a partir das relações possíveis de serem traçadas com as fontes acerca do momento cultural, da situação política e do campo profissional contemporâneos. Para isso, os registros dos encontros que realizamos durante a pesquisa foram utilizados como um guia, um conjunto de informações que nos auxiliaram na reordenação de muitos dos acontecimentos que, no escopo documental, pareciam desconexos.

Partindo dessas idéias iniciais, apresentamos no primeiro capítulo a trajetória de Flavio Motta a partir de seu engajamento na atividade didática, reconstituindo sua carreira de professor. A partir de uma tomada inicial, na qual apresentamos seu contatos com artistas, ingresso no curso de Pedagogia e atividade no MASP, o capítulo se concentra na presença de Flavio Motta como professor na FAU-USP. Trata-se de uma questão chave nesta abordagem, seja pelo vínculo do grupo "paulista" com a escola, seja em função das características peculiares atribuídas ao curso a partir de 62, ou ainda em função da aproximação de Flavio Motta com Vilanova Artigas e Paulo Mendes da Rocha nesse espaço. A reestruturação do curso da FAU-USP em 62 e o papel da história e da crítica nesse quadro, são temas fundamentais ao exame do discurso que pretendemos abordar.

A partir dessa apresentação mais geral, empreendemos os "dois estudos" propostos, de certo modo inspirados por uma prática recorrente na produção escrita de Flavio Motta, que constantemente denomina seus trabalhos teóricos de "estudos", "apontamentos", "anotações". Segundo seu autor, trata-se de uma maneira de manter o trabalho sempre aberto, possível de ser continuado, incorporado a outros "estudos", desdobrado em outros trabalhos ${ }^{4}$. Os estudos que apresentamos, como se fossem dois estudos de caso, têm como foco dois trabalhos de Flavio Motta, com características bastante distintas um do outro.

0 primeiro estudo tem um caráter mais historiográfico: trata-se de uma análise do artigo "Introduzione ao Brasile" 5 , publicado por Flavio Motta na revista italiana Zodiac em 1960. Escrito como texto de apresentação em um número especial sobre o Brasil, o artigo traz uma explicação acerca do aparecimento da arquitetura moderna no Brasil a partir de uma quadro histórico, político e cultural do país. Analisamos este artigo em relação à visão acerca da arquitetura brasileira apresentada por outras revistas internacionais ao longo da década de 50 ,

4 Depoimento de Flavio Motta à autora, em outubro de 2009.

5 Flavio Motta, "Introduzione ao Brasile", in Zodiac, n.6, 1960. Foi realizada durante a pesquisa a tradução desse artigo para o português, que se encontra em anexo nessa dissertação. 
discutindo em que medida ele representa uma visão alternativa da arquitetura brasileira daquela predominante, deslocando o tema da "gênese" da moderna arquitetura brasileira a partir de Le Corbusier, Pampulha e questionando a idéia de seu florescimento milagroso no país.

Além disso, neste número da Zodiac, é apresentado pela primeira vez o arquiteto Vilanova Artigas como articulador de uma proposta alternativa à dita arquitetura moderna brasileira, que teria seus próprios fundamentos teóricos e expressão plástica diferentes daquela difundida internacionalmente como contribuição brasileira ao modernismo internacional. Mais ainda, nesse número da revista Zodiac - tanto no artigo de Flavio Motta, quanto na matéria específica sobre Artigas escrita por Bruno Alfierí - é que se faz pela primeira vez uma aproximação do trabalho de Artigas com as características do brutalismo inglês ${ }^{7}$, idéia que seria difundida na historiografia da arquitetura brasileira num período posterior, no qual se generaliza a idéia de um "brutalismo paulista"8.

Por permitir a discussão do tema da arquitetura paulista inserida neste quadro mais amplo da historiografia da arquitetura brasileira, estabelecendo diálogos com outros discursos sobre o Brasil, que se difundiram internacionalmente ao longo da década de 50, este artigo é nosso ponto de partida. Mas também porque o número da Zodiac pontua um novo período que efetivamente se inicia após a construção de Brasília, em que a arquitetura brasileira e a escola carioca de Lucio Costa e Oscar Niemeyer já não são vistas pela crítica estrangeira com o mesmo deslumbramento da década anterior, e a partir do qual a assim chamada "arquitetura paulista" começa a ter maior visibilidade no cenário nacional.

Nosso segundo estudo é uma tentativa de aproximação mais direta do projeto, da prática profissional. Nosso objeto de análise de análise insere-se na produção de uma obra específica: o pavilhão do Brasil em Osaka, para a Expo de 1970. Obra emblemática da arquitetura "paulista", convergem em seu projeto muitas das idéias e dos paradigmas construtivos que são reiteradamente considerados como exemplares da prática dos arquitetos de São Paulo. Mas o

6 Bruno Alfieri, "João Vilanova Artigas: ricerca brutalista”, Zodiac, n. 06, p.97.

7 "Se quisermos citar ainda um exemplo entre os nomes menos conhecidos da crítica estrangeira, encontramos aquele do arquiteto Vilanova Artigas, que realiza em São Paulo uma intensa atividade doutrinária, seguindo o exemplo de Lucio Costa no que diz respeito às exigências de uma posição teórica. [...] As suas realizações revelaram o esforço de alcançar novas formas através de processos construtivos independentes da instabilidade da nascente indústria da construção. As suas casas, projetadas para intelectuais e profissionais liberais, são caracterizadas pela economia de recursos construtivos, onde, algumas vezes, 0 arquiteto se mistura intimamente à atividade do mestre-de-obras e do operário. Hoje as suas realizações vão amadurecendo em direção a um aparente 'brutalismo'." Flavio Motta, "Introduzione ao Brasile". Zodiac 06, 1960. Tradução da autora, apresentada em anexo.

8 Esta associação da arquitetura paulista ao brutalismo tornou-se tema recorrente quando se trata de estudar este movimento, presente desde trabalhos como de Yves Bruand em 1973, até em estudos contemporâneas, como por exemplo a tese de doutorado de Ruth Verde Zein, A arquitetura da escola paulista brutalista: 1953-1973, de 2007; e os trabalhos de Hugo Segawa, Arquiteturas no Brasil 1900-1990, de 1999 e Mônica Junqueira de Camargo, Joaquim Guedes, de 2000. 
pavilhão é também um símbolo dos diversos deslocamentos e incongruências do período, se considerarmos, por exemplo, que Paulo Mendes da Rocha vence o concurso para a construção do Pavilhão Nacional no mesmo mês em que foi aposentado compulsoriamente de seu cargo de professor na FAU-USP pela ditadura militar.

O projeto do Pavilhão vem despertando ao longo dos anos opiniões tão variadas quanto controversas, tanto por parte dos críticos e historiadores da arquitetura quanto nos diversos trabalhos acadêmicos realizados nos últimos anos, que investigam a obra de Paulo Mendes da Rocha. Os exemplos das diversas abordagens que o Pavilhão desperta são muitos ${ }^{9}$. Há os que o consideram, por exemplo, sob a ótica de sua inserção na "escola paulista", como Hugo Segawa, para quem a obra representa o momento final desta produção, o "marco simbólico de enceramento desse ensaio de vanguarda arquitetônica"10, frente ao desgaste e banalização de sua proposta e os desdobramentos da situação política do país; e no caminho inverso, outros trabalhos, como o de Ruth Verde Zein, que consideram o Pavilhão justamente o "ponto alto" desta vertente ${ }^{11}$, que a partir daquele momento se disseminaria por todo o país. Há ainda trabalhos que analisam o Pavilhão sob a perspectiva de seu valor simbólico, como arquitetura escolhida para representar o país e o inserem na discussão dos valores dessa representação nacional, como é o caso de Isabel Villac ${ }^{12}$.

Além das diversas leituras publicadas sobre o Pavilhão de Osaka, apresentamos no terceiro capítulo, uma outra abordagem de seu projeto que é pouco usual: a partir de sua relação com a Exposição que foi proposta por Flavio Motta para ser apresentada no edifício. A colaboração de Flavio Motta no projeto do Pavilhão, que nos mostra sua desenvoltura e capacidade de interlocução com esse grupo de arquitetos, na verdade é o resultado de um desdobramento de colaborações diretas em outras equipes, como no caso do projeto de Vilanova Artigas para o concurso de Brasília. No Pavilhão do Osaka, entretanto, sua participação é muito mais significativa, e seu produto, o "Plano básico para os trabalhos complementares do Pavilhão do Brasil" nos propõe uma série de questões que remetem diretamente ao nosso tema mais geral.

9 Ainda que seja freqüentemente analisado, os trabalhos que se propõe a apresentar o Pavilhão de Osaka sofrem de uma mesma escassez de material documental, tanto em relação ao projeto do concurso, quanto da documentação da obra construída e da própria feira de Osaka. Invariavelmente encontramos em todos eles as mesmas imagens e desenhos, poucos registros gráficos e fotográficos que se repetem de um para o outro. Nesse sentido, nos esforçamos por organizar também um vasto material documental que foi levantado durante a pesquisa, que se encontra armazenado no acervo pessoal de Paulo Mendes da Rocha. Referência fundamental em nosso estudo, é apresentado aqui integralmente, pois além de seu significado como documento, pode servir como material de consulta à outras pesquisas que porventura venham a analisar o Pavilhão. 0 material organizado se encontra apresentado em anexo nesta dissertação.

10 Hugo Segawa, Arquiteturas no Brasil 1900-1990. São Paulo, EDUSP, 1997, p.157.

11 Ruth Verde Zein, A arquitetura da escola paulista brutalista, 1953-1973, pp.180-181.

12 Maria Isabel Villac. La construcción de la mirada: naturaleza, discurso y ciudad en la arquitectura de Paulo Mendes da Rocha. Tese de Doutorado, Universitat Politècnica de Catalunya / Escola Tècnica Superior d'Arquitectura de Barcelona, 2000, pp.117-131. 
Trata-se de um conjunto de painéis que tem como principal conteúdo a exposição que seria apresentada no interior do pavilhão, que não foi realizada e também nunca publicada ${ }^{13}$. Esta exposição, mais uma vez uma apresentação do Brasil aos estrangeiros, pode ser compreendida como síntese de uma visão da arquitetura muito específica deste grupo. Assim como naquela da revista Zodiac, a apresentação é capaz de inserir a arquitetura numa trama cultural muito mais abrangente. Mas a principal diferença entre esta e aquela é o modo como aqui, dez anos depois, propõe-se um discurso no qual a arquitetura está diretamente relacionada à história, à arte, à ciência, à técnica, ao trabalho, à economia, à ocupação do território e à cultura, e nesse sentido, ela organiza uma proposição teórica que fundamenta algumas práticas de projeto desse grupo paulista ao qual se associa, muito alem das visões freqüentemente redutoras da "escola". A exposição não somente traduz esse discurso, mas inserida no próprio pavilhão, também nos informa como entendê-lo. Por esse caráter, a exposição permite que, através da contribuição de Flavio Motta seja possível pensar as interlocuções entre discurso e obra, entre a crítica e o campo profissional nesse período específico, e por essa razão, é o foco de nosso segundo e último estudo de caso.

Assim, nossos dois estudos têm como ponto em comum o fato de serem duas apresentações do Brasil propostas por Flavio Motta para um público estrangeiro, e deste modo, carregados de intenções e discursos próprios a essa condição. Um mais teórico, centrado nos debates da historiografia, e o outro diretamente articulado a uma obra específica, com valor paradigmático e geracional, que traz com ela os registros e as particularidades pertinentes a uma obra construída ${ }^{14}$. Ao final dos estudos, apresentamos ainda algumas considerações que podem ser tecidas quando pensamos um em relação ao outro.

13 O conteúdo integral da exposição está apresentado em anexo nessa dissertação.

14 Nesse sentido, nos referimos a significação atribuída por Carlos Martins às obras de arquitetura como fontes de pesquisa, que nos fornecem elementos próprios ao seu estudo, que ele denomina "rastro documental direto": os textos, os desenhos e a obra propriamente dita. Carlos Martins, Arquitetura e Estado no Brasil. São Paulo, FFLCHUSP, 1987, p. 2. 



\section{Flavio Motta, entre a arte e o ensino}

A reconstituição da trajetória de Flavio Motta (1923) é uma das várias lacunas da história da arquitetura e das artes no Brasil. Presença determinante no quadro docente da FAUUSP, e na formação de gerações de arquitetos e artistas, responsável pela orientação de alguns dos caminhos empreendidos no Departamento de História e Estética do Projeto, artista, personagem chave em alguns dos mais significativos episódios da arte brasileira, alguns de seus trabalhos são ainda hoje uma referência fundamental no estudo das artes e da arquitetura. E no entanto, não há trabalhos acadêmicos nem publicações que analisem sua trajetória, nem mesmo leituras panorâmicas que organizem sua produção.

Não se trata aqui de tentar empreender essa reconstituição, pois certamente esta tarefa fugiria do escopo de uma dissertação de mestrado, e mais do que isso, a multiplicidade de áreas e instituições por onde Flavio Motta sempre atuou requereria, cada uma delas, outras pesquisas. Além disso, um trabalho monográfico necessitaria ainda uma constante atualização, pois como intelectual dado à ação, mesmo em sua aparente reclusão, Flavio Motta permanece formulando novas investigações, e acrescentando à sua própria obra outros caminhos por onde ver. Por si só, sua produção teórica - que abrange pesquisas e artigos de história da arte e da arquitetura, crítica de arte, monografias sobre artistas específicos - possivelmente já seria material excessivamente vasto para um trabalho da natureza de um mestrado.

Nossa intenção, portanto, é a de lançar uma primeira visada nesta trajetória, mais centrada nas relações entre atuação individual e o campo arquitetônico, no sentido de abrir possibilidades de novas investigações historiográficas, mais do que em recompor sua biografia. Em certo sentido, nosso propósito em ordenar alguns acontecimentos da trajetória intelectual de Flavio Motta, tem mais o propósito de uma introdução necessária aos estudos que nos propusemos empreender, do que efetivamente o de uma sistematização de sua produção. Nosso foco é sua aproximação ao campo da arquitetura, e com este intuito elegemos algumas 
de suas frentes de atuação como assunto principal deste estudo, recorte que certamente deixa em aberto uma série de hiatos a serem preenchidos por trabalhos futuros.

Para esta primeira aproximação, optamos por nos concentrar em tentar organizar sua carreira como professor, em detrimento de sua produção como artista. Sabemos que esta escolha provoca uma cisão que nunca houve em sua trajetória: o trabalho como artista, certamente informa, alimenta e completa a prática do ensino, e especialmente do ensino da arte. Tentamos, sempre que possível, destacar suas ações como artista, no entanto, fica claro que em nossa pesquisa o campo do ensino ganhou muito mais peso do que o das artes, o que não significa que de fato exista essa diferença em seu trabalho. No entanto, estaria além de nossas possibilidades realizar também um estudo que fosse consistente no campo da artes plásticas, e por essa razão escolhemos privilegiar o viés do ensino, que é mais precisamente por onde ele se aproxima dos arquitetos.

\section{1. do modernismo ao moderno, da arte à arquitetura}

Ainda que sua trajetória seja muito diversificada e sua personalidade dificilmente apreensível em um perfil muito coeso, pode-se dizer que Flavio afirmou-se intelectualmente sobretudo como professor, e como professor da FAU-USP em particular. Professor ali desde 1954, participou ativamente do processo de consolidação institucional e projeção nacional da escola, sendo até hoje lembrado por quase todos aqueles que foram seus alunos, independentemente de suas orientações ideológicas ou profissionais, como uma das figuras mais marcantes na formação de sucessivas gerações de arquitetos em São Paulo. Mas se o seu percurso de formação é contemporâneo à gênese da escola, nele se entrecruzam momentos importantes para o entendimento do recorte proposto nesta pesquisa. Marcado por uma bagagem modernista, herdada diretamente da Semana de Arte Moderna, e formado em educação em 1946, o inicio de sua atividade como professor de história da arte deu-se justamente em um período de rotinização e institucionalização da arte moderna em São Paulo, evoluindo a partir do contato com o MASP e a revista Habitat e o ingresso na FAU no momento mesmo em que parecia esboçar-se no país uma critica de arquitetura mais independente da critica de arte. 
Para um jovem com aspirações artísticas, que havia crescido com certa proximidade dos círculos culturais da burguesia paulistana e de diversas figuras que haviam militado pela causa modernista, o campo cultural da década de 40 se apresentava muito mais flexível e diverso do que aquele que fora desbravado pelos modernistas da primeira geração, vinte anos antes.

Os anos que haviam seguido a Semana de 22 assistiram uma "rotinização"1 do modernismo, na qual se ultrapassara definitivamente a fase destrutiva dos anos iniciais, em direção a uma fase construtiva, na qual a modernidade artística entrosava-se com o projeto ideológico de modernização da sociedade. Se, nos anos iniciais de engajamento na luta pela atualização das coordenadas estéticas nacionais, a premissa era divulgar a arte moderna através do escândalo e da provocação da burguesia provinciana recém-estabelecida nas áreas urbanas, neste segundo momento, tratava-se de encontrar um caminho próprio, uma expressão que fosse capaz tanto de dialogar com a realidade nacional, quanto oferecer uma contribuição propriamente brasileira ao movimento internacional.

E a agitação política dos anos 30 também havia trazido, como avaliou o crítico Antonio Cândido, em seu conhecido ensaio "A revolução de 30 e a cultura", uma "tomada de consciência ideológica de intelectuais e artistas", uma radicalização que aproximou o campo da cultura ao engajamento "político, religioso e social", e que

"gerou um movimento de unificação cultural, projetando na escala da nação fatos que antes ocorriam no âmbito das regiões. A este aspecto integrador é preciso juntar outro, igualmente importante: o surgimento de condições para realizar, difundir e "normalizar" uma série de aspirações, inovações, pressentimentos gerados no decênio de 1920, que tinha sido uma sementeira de grandes e inúmeras mudanças. ${ }^{2}$

Tal cenário é contemporâneo ao deslocamento do pólo nacional de vanguarda de São Paulo para o Rio de Janeiro em uma era Vargas de forte presença estatal na cultura. Isso de certo modo explica certa calmaria no ambiente artístico e arquitetônico paulistano ao longo dos anos 1930. Durante a década de 40 a capital paulista assistia a uma intensa transformação, decorrente da consolidação de seu parque industrial, que se desenvolvia com vigor a partir da segunda guerra mundial, sob um regime ditatorial que privilegiava a economia urbana. 0 reflexo do desenvolvimento industrial era um expressivo crescimento populacional e adensamento de seu núcleo urbano com o início da verticalização da área central. Nesse

1 Antonio Cândido. "A revolução de 30 e a cultura". Novos Estudos Cebrap, São Paulo, 1984, p.27.

2 Idem, ibidem, p.27. 
contexto, equipamentos urbanos, instalações comerciais e equipamentos culturais [como cinemas, teatros, bibliotecas, escolas e também museus] instalavam-se na área central, voltados a atender as demandas de uma classe média urbana, consumidora, que começava a se estabelecer na cidade.

A burguesia industrial toma ciência da necessidade de um aparato cultural que desse fôlego a esse processo de metropolização. 0 centro novo ganhava ares de cosmopolitismo, e nos arredores do comércio luxuoso na Rua Barão de Itapetininga a juventude intelectual da Faculdade de Filosofia freqüentava a recém-inaugurada Biblioteca Municipal e a Livraria Jaraguá.

A década de 40 é o período crucial que abre caminho para a inquietação intelectual e artística e a experimentação que se desenvolveria na cidade nas duas décadas seguintes, marcada pelo conflito de grupos e de gerações de intelectuais. Durante esse período, surge uma série de iniciativas culturais que, ao final da década de 40 , originam empreendimentos como o Museu de Arte de São Paulo e o MAM, ambos inseridos num contexto que vinha se estruturando internacionalmente de surgimento de novas instituições de abrigo à arte moderna, "pleiteando transformar a arte moderna em cultura urbana", e que culminam nos empreendimentos culturais de maior fôlego já no início da década de $50^{3}$.

A questão nesse momento era a consolidação de instituições e o desenvolvimento de uma "face pública - com críticos e artistas se envolvendo com as instituições públicas culturais e educacionais." Foi o que notou Francisco Alambert ao examinar o contexto de nascimento da Bienal de São Paulo:

"A nova organização do Estado, as incorporações do modernismo, exemplificadas pelo caso da arquitetura, a profissionalização do artista e os novos ares trazidos por velhos e jovens modernistas radicais mudaram a rota da 'vanguarda' e fizeram também que os modernos se voltassem a um projeto pedagógico, ao mesmo tempo internacional e nacionalista." 4

Também Mario Pedrosa, num balanço do período que separa a Semana de 22 da realização das Bienais, evidencia esta mudança de quadro: "o ambiente de alta tensão social e de crise institucional não permitia mais as explosões puramente estéticas ou culturais da semana" 5 . Neste contexto, durante aquela que ele chamava de uma "segunda fase"

3 Maria Cecília França Lourenço, Museus acolhem moderno, São Paulo: Edusp, 1999, p.11.

4 Franciso Alambert, As Bienais de São Paulo: da era do Museu à era dos curadores (1951-2001). São Paulo: Boitempo, 2004, p. 26

5 Mario Pedrosa, “A Bienal de lá pra cá”, Política das Artes, São Paulo: EDUSP, 1995, p.247. 
do modernismo brasileiro, "o pensamento dominante já tem uma certa conotação social e coletiva, e não por acaso o verdadeiro protagonista é agora o arquiteto."6

De fato, sobretudo no Rio de Janeiro, a arquitetura já havia assumido a dianteira nos debates culturais no final da década de 30 após o "surto sensacional"7 financiado pelo Estado, que havia abraçado a causa modernista como expressão nacional, e especialmente a arquitetura moderna como a imagem da modernização do país. Desde as iniciativas de Gregori Warchavchik em São Paulo, as tentativas de renovação da ENBA no Rio de Janeiro, e em seguida o deslocamento do centro dos debates estéticos de uma cidade a outra, o grupo carioca articulado em torno de Lucio Costa ganhava lugar de destaque no plano cultural nacional e, na década seguinte, conquistaria definitivamente seu lugar frente ao movimento moderno internacional. Ainda que tardiamente, também em São Paulo a arquitetura vinha ascendendo como expressão cultural de uma modernidade urbano-industrial desde o final dos anos 1940. Inicialmente visível na intensa atividade privada de construção civil que difundia em meio aos empreendimentos imobiliários novas concepções de projeto na cidade ${ }^{8}$, em meados da década de 1950 também em São Paulo a arquitetura irá adquirir relevância cultural e política.

Um dos caminhos por onde é possível perceber esse movimento de valorização da arquitetura que se desenvolve ao longo dos anos 40 e 50, e que nos interessa particularmente, é através do modo como os críticos de arte, progressivamente, passam a tratar a arquitetura como assunto autônomo, e a cada vez mais refinar seu modo de olhar as questões próprias a este campo, abrindo caminho para uma maior especialização ${ }^{9}$. Nesse movimento no qual a arquitetura vai ganhando autonomia dentre os temas das artes plásticas, é possível, através da crítica, perceber um trânsito e uma interlocução entre artistas, arquitetos, críticos e intelectuais, muito próprio a este período. Como tais interlocuções e mediações entre o campo arquitetônico e o campo artístico são um dos interesses mais gerais deste trabalho, detenhamo-nos por um momento na gênese desse campo especializado da critica.

A crítica de arte dos jornais da cidade freqüentemente dedicava espaço para comentar os feitos arquitetônicos, porém muito mais no sentido de utilizar os exemplos arquitetônicos para alimentar as discussões mais gerais acerca da constituição de uma arte nacional ou de um projeto construtivo no país. A medida em que a arquitetura não representava uma manifestação que demandasse um olhar especializado, os profissionais dedicados a comentar

6 Idem, ibidem, p.241.

7 Idem, ibidem, p.241.

8 A esse respeito ver José Lira, Fraturas de Vanguarda em Gregory Warchavchik. São Paulo: FAUUSP, 2008.

9 Outro indício desse importância é a presença significativa que a arquitetura moderna brasileira irá assumir no plano internacional. Trataremos dessa presença nas revistas internacionais no capítulo seguinte. 
a produção arquitetônica quase sempre estavam ligados a outras áreas do campo cultural. E mesmo os arquitetos mais engajados, quando no início da década de 20 começam a publicar artigos nos jornais, dificilmente escreviam no sentido de um juízo ou análise mais sistemática da produção local como aqueles dos críticos de arte. Se este fato, a princípio, poderia constituir uma distância entre o pensamento crítico e o cotidiano da profissão, por outro lado nos permite aproximar a crítica de arquitetura de um escopo mais geral da cultura e das artes, e ainda, perceber o trânsito e a interlocução entre arquitetos, artistas, intelectuais, e estabelecer relações entre o círculo do modernismo e a arquitetura moderna que começava a ganhar espaço na cidade.

É possível apanharmos o lugar que a arquitetura vai gradativamente ocupando no debate cultural mais amplo já a partir de alguns escritos de Mário de Andrade, que publicou em 1928 seus primeiros ensaios acerca da arquitetura contemporânea na sessão de arte que manteve no Diário Nacional entre 1927 e 1931, inscrevendo o tema da arquitetura no debate cultural local ${ }^{10}$. Pode-se dizer que a primeira aproximação crítica partindo dos intelectuais às manifestações específicas do campo da arquitetura moderna entre nós, vem desses artigos de Mario.

Neles, o mais notável crítico militante do modernismo paulista chamava a atenção para a possibilidade de reconhecer as manifestações pioneiras de Warchavchik e Flávio de Carvalho ao mesmo tempo como sinal de uma ruptura na tradição acadêmica dominante e como expressão de um vinculo concreto tanto com as tendências internacionais contemporâneas, quanto com o momento nacionalista do movimento modernista no Brasil. Nestes primeiros textos, o foco da discussão é a análise do que se constrói no país e seu papel no enfrentamento da dualidade entre o nacional e o internacional, o regional e o universal. Tratava-se de saber se esta produção correspondia a uma expressão válida da nacionalidade, tal como se postulava para as artes em geral na segunda metade da década de 1920.

Este enfoque será, no entanto, gradativamente reformulado pelo próprio Mario de Andrade à medida que nos aproximamos da década de 30 , quando seus escritos começam a ter como eixo uma outra esfera de preocupações ${ }^{11}$. Neste momento, sua crítica de arte terá como foco a sintonia entre o que se consagrou no país como uma arte ao mesmo tempo moderna e

10 Ricardo C. de Souza, "Mário, crítico da atualidade arquitetônica", Revista do Patrimônio, no 30, 2002. Neste artigo, são analisados os textos de Mário que tratam da arquitetura contemporânea, nos quais o autor reconhece um "esforço de síntese entre a realidade brasileira e os movimentos mundiais de renovação" no campo da arquitetura e das artes em geral [p. 26]. Os artigos publicados no Diário Nacional em 28 são: "Arquitetura Brasileira" [28 de janeiro], "Arquitetura moderna I" [02 de fevereiro], "Arquitetura Moderna II" [03 de fevereiro], "Arquitetura Moderna III" [04 de fevereiro], e a séria de quatro artigos intitulados "Arquitetura colonial" [23, 24, 25 e 16 de fevereiro].

11 Gilda de Mello e Souza, "Vanguarda e nacionalismo na década de 20", Exercícios de Leitura. São Paulo: Duas Cidades, 1980, p.261. 
nacional e a produção internacional contemporânea, correspondendo às discussões em voga nesse período. Mario aparentemente permanece distante do tema da arquitetura ao longo da década de 30, no entanto, essa inflexão em seu olhar evidencia-se no texto publicado em 1943 acerca do lançamento do catálogo Brazil Builds ${ }^{12}$. Neste momento, a arquitetura moderna do grupo carioca já se oficializava, e de certo modo, o estágio de formação do campo arquitetônico já permitia um ponto de partida novo. Não mais se tratava de pleitear um nexo entre a renovação arquitetônica e o projeto nacional-modernista, como nas críticas à obra de Warchavchik. Com o MEC, essa síntese cultural já era um dado, tratando-se agora de buscar critérios novos para o entendimento da produção arquitetônica como expressão coletiva da modernidade.

Certamente, um dos mais notáveis exemplos de crítico de arte que se dedicou a comentar sistematicamente a arquitetura contemporânea foi Geraldo Ferraz, muito atuante nos jornais locais e bastante influenciado pela atmosfera do modernismo. Ligado à produção jornalística desde o início da década de 20, Ferraz foi o primeiro crítico modernista a atuar profissionalmente na imprensa paulista. Seu conhecimento da matéria advinha do exercício profissional; ao contrário dos outros críticos, que construíram sua reputação a partir de uma produção intelectual variada, Ferraz era um "proletário" da redação, tendo exercido várias funções na produção jornalística, desde tipógrafo, até revisor e finalmente repórter, a partir de $1928^{13}$. Até 1938, quando Sergio Milliet ingressou no jornal O Estado de São Paulo, Ferraz era o único crítico de arte a exercer esta função regularmente na cidade ${ }^{14}$.

É importante ressaltar que o espaço preferencial do exercício da crítica neste período eram as redações dos jornais. Não apenas porque os poucos veículos de arquitetura disponíveis reproduziam perfis editoriais pouco angulados criticamente, mas também porque todo o ambiente da crítica jornalística refletia uma situação profissional muito menos especializada, na qual interessava mais a capacidade de trânsito entre os diversos campos da cultura, as relações mais pessoais com os artistas e intelectuais, do que um conhecimento mais específico acerca dos assuntos da arte:

12 Mário de Andrade, "Brazil Builds", Arte em Revista no 4, 1980, p. 26. Nesse artigo, Mário identifica que "a primeira 'Escola' de arquitetura moderna no Brasil, foi a do Rio, com Lucio Costa a frente, ainda que o pioneirismo do movimento tivesse ocorrido em São Paulo, com Warchavchik, vinte anos antes."

13 José Lira, "Jornalismo, crítica modernista e Urbanismo: Geraldo Ferraz em São Paulo, da Semana a Brasília", artigo apresentado no Congresso da ANPUR, 2007, p.02. Em 28, Ferraz escrevia pequenas contribuições na revista modernista Festa, no Rio de Janeiro, e colaborava esporadicamente na redação do Jornal do Comércio e Folha da Manhã, e estabeleceu-se na redação do Diário da Noite. Foi também repórter do Associado e do Diário Nacional, assim como Mário, Milliet, Tácito de Almeida e outros intelectuais do período.

14 Sobre um panorama do campo profissional dos críticos na cidade, neste período, ver Heloísa Pontes, Destinos mistos: os críticos do grupo clima em São Paulo (1940-68). São Paulo: Companhia das Letras, 1998, pp.42-51. Ver também Juliana Neves, Geraldo Ferraz e Patrícia Galvão : a experiência do Suplemento Literário do "Diário de S. Paulo" nos anos 40. São Paulo: Annablume, 2005. 
“Na ausência de publicações especializadas e de críticos também especializados, a crítica de arte no período era veiculada basicamente através da imprensa diária e, secundariamente, nas revistas culturais. O jornal era o órgão central para os críticos divulgarem suas opiniões e análises sobre artes plásticas. Os livros que editavam nesta área eram, quase sempre, coletâneas de artigos publicados primeiro na imprensa. Nesse contexto de baixa institucionalização da atividade intelectual, no qual o diploma de advogado conferia como que um passaporte imediato para o exercício de atividades várias no campo cultural e jornalístico, não era necessário ainda deter um conhecimento amplo e simultaneamente específico para habilitar-se à crítica de arte. Este era adquirido ao decorrer do itinerário dos críticos." 15

Foi através da amizade com intelectuais modernistas paulistas e cariocas, e principalmente com Warchavchik e Flávio de Carvalho, que Ferraz começou a concentrar suas preocupações e seus escritos nas questões de arquitetura. Através deles, gradativamente familiarizava-se com as idéias de Le Corbusier, tornava-se leitor de revistas internacionais como Art et Decoration e Cahiers d'Art, passando a divulgar com cada vez mais freqüência os acontecimentos arquitetônicos e urbanísticos na cidade. Em função de seu reconhecimento, de um certo prestígio no trato da matéria específica, foi convocado a entrevistar o arquiteto franco-suíço quando este chegou em São Paulo em 1929, e acabou sendo seu principal cicerone na visita à cidade.

Entre os anos 20 e 40, Ferraz parecia esforçar-se em prol do refinamento da atividade crítica em arquitetura, e claramente influenciado por um cânone do movimento moderno, aprofundar o domínio do linguagem internacionalista como forma de resistência às premissas nacionalistas tão em voga no debate arquitetônico do período. Ao assumir a dianteira no debate arquitetônico nos jornais, gradativamente foi alçado a um papel de destaque, e mesmo de liderança, no debate das questões arquitetônicas a partir do final da década 40 e início da década de $50^{16}$. Uma evidência dessa posição pode ser atestada através do famoso debate com Lucio Costa, no final de 1948, acerca do pioneirismo de Warchavchik na introdução do modernismo arquitetônico no país, em detrimento da produção carioca, que vinha sendo amplamente divulgada naquele momento.

Ferraz cobrava do arquiteto que era o principal articulador da arquitetura moderna carioca - e a essas alturas, uma das figuras mais importantes do campo cultural brasileiro - 0 
reconhecimento da primazia de Warchavchik ${ }^{17}$; ao mesmo tempo, pela primeira vez trazia ao debate a possibilidade de se pensar um projeto moderno paulista na arquitetura distinto do carioca, que se distanciavam um do outro, nas palavras de José Lira, pela diferença entre "a teimosia autodidata e sistemática de arquitetos imigrantes e o luxo de exotismo e gratuidade dos artistas nacionais à sombra das instituições, explicação já recorrente quanto a pintura modernista em sua fase inaugural nas duas cidades"18.

E ainda neste panorama da constituição de um campo específico da critica de arquitetura, na década de 40 também outros críticos de arte também começam a dedicar espaço nos jornais às questões mais especializadas, como Sérgio Milliet e Luis Martins; no entanto, um deles foi particularmente perspicaz em apanhar essa diferença entre o modernismo carioca e o modernismo paulista nas artes: Lourival Gomes Machado, que foi o primeiro dos críticos de jornal a atuar dentro de moldes mais acadêmicos. Egresso da Faculdade de Filosofia da USP, onde era professor desde o final dos anos 30, Lourival estreou como crítico de arte na revista Clima ${ }^{19}$ em 1941, e no ano seguinte já era colaborador regular nos assuntos de artes plásticas nos jornais Folha da Manhã e Folha da Tarde.

"Na condição de um dos expoentes maiores da primeira geração de alunos formada pela universidade de São Paulo, Lourival procurou se apresentar como o vocalizador mais legítimo das demandas de Mário de Andrade, com vistas à superação do amadorismo e do experimentalismo no plano intelectual. Entre os críticos atuantes no período, apenas ele havia sido formado por meio daquela "consciência profissional" que, no entender de Mário, caracterizava tanto a pintura quanto as ciências sociais feitas em São Paulo. Os outros, em sua maioria egressos do modernismo, por direito, relação, ou casamento, exerciam a crítica de arte em conjunto com outras modalidades de trabalho intelectual, notadamente o jornalismo e a literatura. "20

Lourival logo assumiu papel de destaque no cenário das artes no país. Em 1947, quando publicou seu livro Retrato da Arte Moderna no Brasil ${ }^{21}$, procurava reconhecer e avaliar as inovações estéticas pelas quais a arte brasileira havia passado e também consolidar

17 Geraldo Ferraz, "Quem é o pioneiro da arquitetura moderna brasileira? Falta o depoimento de Lucio Costa", artigo publicado no Diário de São Paulo, 01 de fevereiro 1948.

18 José Lira, "Ruptura e construção: Gregori Warchavchik, 1917-1927", Novos Estudos n.78, pp. 145-167, jul. 2007. A esse respeito ver também a apresentação de Carlos A. Ferreira Martins ao livro Arquitetura do século XX e outros escritos, Cosac \& Naify, 2006.

19 A respeito da trajetória de Lourival e seus companheiros do Grupo Clima, ver Heloísa Pontes, op. cit.

20 Heloísa Pontes, op. cit., p.47.

21 Lourival Gomes Machado, Retrato da arte moderna no Brasil. São Paulo: Departamento de Cultura, 1947. 
sua posição de crítico de arte no cenário nacional. Este trabalho também representou uma mudança de interesses em sua produção, um ponto de inflexão em sua carreira, na qual, até então, prevalecia uma postura militante e alinhada com as temáticas modernistas. A partir dos estudos iniciados com esta publicação, gradativamente Lourival passou a dedicar-se também à arte colonial brasileira ${ }^{22}$.

Em seu livro, na procura de um diálogo entre a arte brasileira e a produção internacional, dedica uma pequena parte às questões da arquitetura moderna. Neste breve comentário, destaca tanto o pioneirismo de Flávio de Carvalho e Warchavchik, quanto a competência do "grupo do Ministério", que soube "erguer a nova casa sobre a própria terra e dela ir tirando aos poucos uma fisionomia autêntica, natural"23. No entanto, não encerra o assunto da produção nacional arquitetônica no grupo carioca. Faz questão de destacar ainda uma "segunda fase" da arquitetura moderna em São Paulo, uma produção intensa na qual era possível perceber a influência marcante dos arquitetos estrangeiros estabelecidos na cidade (citando como exemplo Rudofsky e Rino Levi). Para ele, a prática arquitetônica na cidade naquele período

"não fica a dever ao exemplo carioca. Sua fisionomia topográfica e a ausência de grandes palácios ministeriais talvez leve a cidade a se tornar o grande centro arquitetônico destinado a resolver os problemas peculiares à casa de moradia" ${ }^{24}$.

Ao lado de seu interesse pela arte colonial e pela arquitetura barroca, que se desenvolveria ao longo da década de 1950, poucas vezes se notou o papel que Lourival Gomes Machado viria a desempenhar também como crítico e observador da arquitetura contemporânea. A verdade é que, sem abandonar seu campo de origem, as ciências sociais e a crítica das artes plásticas, aproximou-se também dos arquitetos contemporâneos e de sua produção, provavelmente em decorrência de sua presença na FAU, onde ingressou em 1952, como professor titular junto à cadeira de História da Arte. Alguns artigos do período testemunham a proximidade do crítico às realizações mais recentes dos arquitetos de São Paulo, em conformidade com as discussões mais específicas do campo profissional. É o caso, por exemplo, de um artigo que publica a respeito do projeto do jovem arquiteto João Walter Toscano para a Faculdade de Filosofia em Itu:

22 Idem, ibidem, p.22.

23 Lourival Gomes Machado, Retrato da arte moderna no Brasil, São Paulo: Departamento de Cultura, 1947, p.82.

24 Idem, ibidem, p.83. 
"Faz gosto verificar, das grandes diretrizes da concepção construtiva até as minúcias do detalhamento de uma obra, essa severidade e essa franqueza na convocação dos materiais e das técnicas que, longe de inibirem, instigam o criador de arquitetura na aspiração de maior beleza expressiva. Nos dois corpos que, num ângulo reto, se sobrepõem nos extremos, nessa torre que toca, mas não se funde na massa principal quando soluciona a carga maior da circulação vertical, há um rigor e uma simplicidade que lembram o impositivo esquematizo do organograma funcional dos primeiros estudos, porém jamais teria o arquiteto chegado à formulação definitiva se, reagindo ao construtivo primário, não a fosse pedir à arte de construir imaginosa, porém submissa à mais pura economia de meios. ${ }^{25}$

Podemos perceber que a partir de um certo momento Lourival adquire familiaridade com o vocabulário e os elementos específicos de projeto. Esse refinamento do olhar revela um maior entrosamento entre a produção arquitetônica e a atividade crítica, resultando talvez de uma exigência de rigor teórico compatível com a crítica em moldes universitários. Ao mesmo tempo, essa maior especialização da crítica de arte nos assuntos da arquitetura, revela a autonomia que o campo arquitetônico vai adquirindo em relação ao circuito artístico da cidade, o que definitivamente se consolida na década de 50, sobretudo após a multiplicação de revistas especializadas, exposições, e instituições profissionais e de ensino independentes.

\section{2. o início pela pintura}

Um jovem que decidisse iniciar uma carreira de artista em São Paulo no início dos anos 40, encontraria um ambiente já familiarizado com a arte moderna, um clima de transformações, e ao mesmo tempo, a arquitetura assumindo um lugar central no campo cultural brasileiro.

Ainda que fosse muito jovem para ter qualquer proximidade dos modernistas de primeira geração, e dos acontecimentos e disputas que seguiram à Semana, Flavio Motta provavelmente teve oportunidade de conviver com alguns dos principais personagens dos círculos modernistas, pois seu pai, Cândido Motta Filho, havia sido um dos intelectuais engajados na atualização das 
coordenadas estéticas junto ao grupo modernista na década de 20. Advogado ${ }^{26}$, dedicou-se também ao jornalismo e à política, tendo trabalhado como encarregado da coluna judiciária e também da página de literatura no Correio Paulistano, redator-chefe da Folha da Manhã e crítico literário dos Diários Associados. Representava, nesse sentido, um exemplo típico dos intelectuais multifacetados da década de 20 , que atuavam simultaneamente em várias frentes e especialmente na imprensa, que vivia um verdadeiro surto de crescimento naquele período ${ }^{27}$. Além disso, também tomou parte na Semana de 22 através da publicação de estudos críticos do modernismo nos jornais, e mais tarde, com Cassiano Ricardo e Menotti del Picchia, promoveu o Movimento Verde-Amarelo, que procurava imprimir uma diretriz patriótica à literatura brasileira.

Ainda que suas referências familiares fossem essas mais ligadas a essa primeira geração de modernistas, no final dos anos 30, quando decide estudar pintura e desenho, Flavio Motta se aproxima dos artistas da Família Artística Paulista, que em meio a efervescência e diversidade de manifestações do período, certamente foi aquele que mais instigou intelectuais e críticos, apesar de sua curta duração.

A Família aparece a público, oficialmente, em outubro de 1937, quando realiza sua primeira exposição coletiva ${ }^{28}$, às vésperas do golpe do Estado Novo, e no mesmo ano do primeiro Salão de Maio. É possível apreender, a partir das críticas e leituras realizadas posteriormente, que havia, pelos olhos do público e da crítica, um clima de oposição entre os "modernistas" e a Família, desde esse primeiro momento de divulgação pública. A imagem de que a Família e os modernistas eram grupos contrários só se desfaz quando Mario de Andrade publica um artigo comentando o trabalho desses artistas, na ocasião da segunda exposição do grupo, em 193929. A partir desse artigo, as interpretações feitas a posteriori acerca da produção da Família Artística Paulista convergem para um mesmo tipo de leitura.

O grupo, que era composto por pintores de parede e outros artesãos de origem imigrante, é constantemente identificado através de sua origem nos bairros operários, chamados por Mario de Andrade de "pintores proletários". Em sua pintura não se reconhecia a tendência "moderna", o que deu margem as interpretações de que seriam "contrários" a este movimento, num contexto onde ainda prevalecia uma polarização e disputa entre modernos e acadêmicos. Paulo Mendes de Almeida em seu livro foi um dos que destacaram a atualidade daquela pintura. Se ela

26 Posteriormente, tornou-se professor da Faculdade de Direito da USP e Ministro da Educação entre 1954 e 1955.

27 Segundo Durand, dos 116 periódicos existentes em São Paulo em 1941, cerca de 90 havia sido criados a partir da década de 20. José Carlos Durand, Arte, privilégio e distinção: artes plásticas, arquitetura e classe dirigente no Brasil, 1855/1985. São Paulo: Perspectiva, 1989, p.104.

28 A Família realizou apenas 3 exposições: a primeira em 37, no grill do Hotel Esplanada; a segunda em 1939 , no subsolo do Automóvel Clube, e a terceira em 1940, no Rio de Janeiro, conforme esclarece Paulo Mendes de Almeida, De Anita ao Museu. São Paulo: Perspectiva, 1976.

29 Mario de Andrade, "Esta paulista família", O Estado de São Paulo, 02/07/1939. 
"nada tinha, na intenção, de revolucionária; nem se a poderia, tampouco, rotular de passadista. Pensava em realizar uma arte contemporânea, que se prevalecesse das lições do passado [...] No processo evolutivo das artes plásticas no Brasil, preferia uma palavra de prudência que significava, sobretudo, uma atenuação no sentido polêmico do movimento que tivera início com a semana de arte moderna" 30

Nesse sentido, no centro de suas preocupações haveria muito mais uma mentalidade artesanal, na qual os artistas procuravam "restabelecer um certo equilíbrio, retomar o fio da tradição em arte, prevenindo e prevenindo-se contra os desvarios e facilidades cometidos em nome da liberdade de expressão"31. Tendo como referência essa leitura de Mario de Andrade, Paulo Mendes de Almeida assim descreve o grupo:

“A Família Artística Paulista veio afirmar uma louvável crença na imprescindibilidade do métier, da apuração dos elementos técnicos e formais da arte de pintar, o que significou um poderoso estímulo à formação de uma consciência profissional nos jovens artistas brasileiros, especialmente nos de São Paulo, e representou assim, e sem dúvida, um importante passo na evolução da arte moderna no país, entendida num sentido mais amplo. "32

Flavio Motta começa a estudar desenho e escultura com José Cucê no final dos anos 30, provavelmente nos cursos que o escultor (acadêmico) ministrava no Sindicato dos Artistas Plásticos. O Sindicato havia surgido a partir da extinção da Sociedade Paulista de Bellas-Artes, associação criada em 1921 com a finalidade de agregar os artistas da cidade e promover um maior contato com o público. A Sociedade, apesar de sempre haver se mostrado indiferente quanto às tendências modernas, ao mesmo tempo recebia em suas exposições artistas que estavam longe de ser considerados acadêmicos, como Zanini, Volpi, Bonadei, Gobbis, etc., muitos deles ligados à Família Artística Paulista, contribuindo, conforme observa Paulo Mendes de Almeida, para diluir a separação maniqueísta de debate daquele período que opunha a "arte do passado" e a "arte do presente" 33 .

Em 1937, motivada pela legislação trabalhista que entra em vigor com o Estado Novo, a Sociedade Paulista de Bellas-Artes transforma-se em sindicato de classe. Surgia assim o

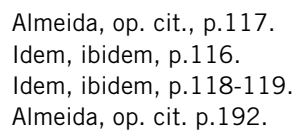


Sindicato dos Artistas Plásticos de São Paulo, e José Cucê se torna seu presidente. Promovendo anualmente seus salões, o Sindicato acabou por acolher também os artistas modernos - até mesmo os de primeira geração, muitos dos quais haviam participado dos Salões de Maio, do CAM e da SPAM ${ }^{34}$. Sua criação fortaleceu um esforço que vinha reunindo os artistas do período em profissionalizar-se, uma preocupação que unia tanto "o grupo modernista quanto o dos proletários", juntando esforços para "participar ativamente na formação de instâncias de divulgação, de consagração, e em pensar na possibilidade de venda dos quadros". Esse interesse também é identificado por Mario Pedrosa: "As preocupações profissionais vinham a tona por toda parte e as preocupações ideológicas ou políticas passavam para trás [...] A era dos clubes de arte "moderna" estava morta; não por acaso surge, em seu lugar, o Sindicato de Artistas Plásticos" 35 , e é através desse espaço que Flavio Motta conhece e se aproxima dos artistas da Família.

Trinta anos mais tarde reafirma essa relação em um breve escrito acerca do trabalho de seus primeiros mestres, na revista do Instituto de Estudos Brasileiros. 0 texto "A Família Artística Paulista", publicado em 1971, é acompanhado por uma compilação bibliográfica sobre cada um dos artistas do grupo. 0 texto parte do artigo de Mario de Andrade de 39, e como uma apresentação primeira desses artistas, e no mesmo sentido de outros críticos estudados, ressalta o aspecto "proletário" e a vontade em "aprimorar o métier" como sendo a especificidade desse grupo de artistas:

"buscavam, por intermédio da pintura, uma nova qualidade que substituísse as árduas exigências do trabalho, impostas pela condição proletária. Se por um lado, passar de "pintor de liso" a "pintor de quadro", pode corresponder a um "enobrecimento", por outro lado se verifica a depuração do ofício em íntima relação com uma temática dada a "luxos", [...] compreendiam o mundo que os cercava, como a resultante de penosas conquistas do trabalho. Procuravam avançar com os recursos que dispunham. Propunham, a partir desse universo circundante, revalorizá-lo com os meios técnicos e sugestivos da pintura. [...] participar daquele grupo era mais uma questão de solidariedade no trabalho do que de especulações estéticas “ 36

34 A respeito das atividades dos Salões de Maio, do Clube dos Artistas Modernos e da Sociedade Pró-Arte Moderna, ver Paulo Mendes de Almeida, op.cit.

35 Pedrosa, op. cit. p.248.

36 Flavio Motta, "A família artística paulista". Revista do Instituto de Estudos Brasileiros n.10, São Paulo, 1971, pp.137154. 
Escrito em um momento de enraizamento do autor na atividade acadêmica, é natural que na apresentação do grupo de artistas o professor sugira uma série de possibilidades de investigação a partir do assunto. Um exemplo seria a realização de um estudo que procurasse compreender, a partir da Família Artística Paulista, "a história da contribuição do imigrante e seus filhos para o aprimoramento das relações de trabalho e de produção dentro da vida brasileira"; ou então, estudar a partir do artigo de Mario de Andrade de 1939, questões acerca da relação entre o erudito e o popular - que ele considera uma questão crucial para entendermos a arte brasileira, e mais especificamente a arquitetura; esse estudo poderia partir justamente do encontro entre Mario de Andrade e os artistas da Família, "o erudito diante do popular", o que nos permitiria

"procurar identificar, como no Brasil, com os recursos que dispomos para a realização de obras de arte, conseguimos encontrar soluções novas que respondem a interesses sociais. Isto ainda estabelece uma solução metodológica, por que permite examinar um conjunto de problemas - obras de arte, artistas, meio, história - onde cada elemento se pode explicar pelo conjunto e ao mesmo tempo contribuir para explicar o conjunto". ${ }^{37}$

Em suma, ele apresenta como possibilidade de trabalho, a proposta de partir de um assunto específico e transgredi-lo para outras esferas de indagações. É importante ressaltar que esta postura é uma recorrência em seus trabalhos: percebemos em sua produção escrita a insistência em não "fechar" os assuntos. Seus trabalhos nunca procuram encerrar as questões propostas, ao contrário, constantemente tentam desmembrar aquilo que seria um estudo inicial em uma nova cadeia de possibilidades de abordagem daquelas questões. E a recorrência com que utiliza esse recurso em seus textos sugere que possamos entender esta prática quase como um "método de trabalho", uma proposta metodológica de como fazer um "estudo". Nesse sentido, é muito claro o caráter didático, para não dizer pedagógico, que é possível reconhecer em todos os seus textos; o exercício de abrir quantas hipóteses de trabalho forem possíveis, a partir de cada questão inicial, reforça a idéia de que o mais importante a cada estudo é o conhecimento possível mobilizado para cada questão, e não necessariamente alcançar uma conclusão.

Essa característica de abordagem dos temas é também uma forma de fazer com que nada perca o sentido ao ser olhado a partir de um ponto de vista contemporâneo; trata-se 
de uma constante atualização dos sentidos possíveis presentes em cada problema inicial. Significa uma constante atualização do olhar, que parte dessa possibilidade de olhar múltiplo para cada problema. É uma característica da produção de Flavio Motta essa abertura para a multiplicidade de abordagens e modos de ver, de modo que todos os temas, mesmo aqueles mais específicos, possam conter todas as outras questões. Em seu trabalho, é sempre possível buscar entender "como é que o problema pode transpor, tanto por seus valores artísticos, como pela crítica, uma significação histórica, um sentido, um direcionamento, à medida mesmo em que revela, as transformações, as condutas em nossa sociedade e nossa cultura." ${ }^{38}$

Mas trataremos das especificidades de seu trabalho mais adiante. Por hora, voltemos a seu ambiente de formação no início dos anos 40 , e de sua proximidade dos artistas proletários desse período. Seu texto sobre a Família Artística Paulista termina justamente localizando esta proximidade do autor com o grupo que apresenta no artigo:

“É este material e estas considerações que apresentamos na certeza de nos unirmos às primeira e instigantes análises de Mario de Andrade. Por certo, elas assumem, pelas circunstâncias que caracterizam este trabalho, uma preocupação mais entusiástica do que conclusiva, por termos vivido a nossa juventude - e daí para sempre - ao lado do clima de camaradagem com esses artistas, embora assim se comprometa no reconhecimento do dinamismo da nossa história que vai se fazendo." 39

Nesse período, Flavio Motta dividia um ateliê no centro da cidade com mais três amigos pintores - Raphael Galvez, Sylvio Alves e Odetto Guersoni - que havia conhecido neste mesmo círculo de relações do Sindicato e dos grupos de artistas que o freqüentavam. É nesse período também que conhece Vilanova Artigas, que era próximo a esse mesmo grupo de artistas, acompanhando sua esposa Virgínia, que era pintora e gravadora. 0 nome de Artigas consta também como participante da segunda exposição da Família Artística, em 1939.

Um evento significativo do período, que aparentemente teve grande repercussão em muitos dos artistas dessa geração, foi a Exposição de Arte Francesa, que Flavio Motta menciona em seu texto sobre a Família. Inaugurada em 1941, na Galeria Prestes Maia, tratava-se de uma mostra enviada pelo governo francês, que percorreu diversas cidades. Mario 
Pedrosa acusou a exposição de conservadora ${ }^{40}$, no entanto ela contou com o entusiasmo dos pintores da Família e mobilizou muitos dos jovens artistas do período.

\section{3. anos de formação: educação e arte, da USP ao MASP}

Em paralelo aos estudos de pintura e à aproximação dos artistas, Flavio Motta ingressou no curso de Pedagogia da Faculdade de Filosofia, Ciências e Letras da USP41. O curso de Pedagogia havia sido incorporado a FFCL em 1939, quando a escola já estava em funcionamento há 5 anos, após intensos debates acerca das novas propostas educacionais do país.

Um dos intelectuais mais engajados na questão da educação, Fernando de Azevedo, em muitos de seus escritos, registra a seqüência de acontecimentos e decisões que envolveram as novas diretrizes educacionais para o país a partir da década de 30, processo no qual ele próprio foi um dos principais artífices, responsável por muitas das propostas implementadas. Em um dos capítulos de $A$ Cultura Brasileira, ele reconstitui as mudanças que conduziram às novas diretrizes educacionais brasileiras, e o processo que originou o curso de Pedagogia na FFLC ${ }^{42}$.

Em 1933, Fernando de Azevedo, então no cargo de Diretor Geral de Instrução do Estado de São Paulo, nomeado pelo interventor Armando Salles de Oliveira, publicou um novo Código de Educação, que reformulava as diretrizes do ensino e o aparelho da educação pública. Entre uma série de novas medidas, criava o Instituto de Educação, e reestruturava o ensino normal, que agora se transformava em curso profissional com três anos de duração, e estava sob

40 "Com a retomada do comércio mundial e conseqüente intensificação das comunicações internacionais, à cata de retemperar seu prestígio muito abalado com a guerra, manda a França, primeira que qualquer outra nação, uma mostra ambulante coletiva de arte francesa do século XIX aos contemporâneos; era uma retrospectiva não muito completa e ressentindo-se de certo conservadorismo na sua seleção. 0 sr. Germain Bazin, o engomado conservador-chefe do Louvre, estava longe de ser um homem em dia. (...) Não convenceu as gerações mais novas, ansiosas por expressões mais audazes e revolucionárias". Mario Pedrosa, op. cit., p.249. Segundo Alambert, o comentário de Pedrosa sobre os franceses marcaria uma crise da hegemonia francesa e o início da americana no campo artístico, o que o debate sobre o abstracionismo no âmbito dos Museus e das Bienais traduziria no pós-guerra. Alambert, op. cit.,p.30.

41 Flavio não se recorda precisamente do ano de seu ingresso nem o da formatura, porém lembra-se que aproximou-se de Pietro Maria Bardi e do grupo do Museu durante o último ano de seu curso, e que já havia se graduado quando o Museu foi inaugurado, o que nos leva a concluir que se graduou no ano de 1946. E segundo seu depoimento, permaneceu na Faculdade por 5 anos - os 4 anos de curso mais um ano em que esteve afastado em função do serviço militar, portanto é provável que tenha ingressado no curso de pedagogia aos 19 anos, em 1942.

42 Fernando de Azevedo, A cultura brasileira. São Paulo: Melhoramentos, 1964. 
responsabilidade do mesmo Instituto. Estas novas orientações vinham sendo discutidas em movimento encabeçado pelo próprio Fernando de Azevedo desde 1927, num debate de diretrizes nacionais, que culminaram na publicação do Manifesto dos Pioneiros da Educação Nova, de 1932, redigido por um grupo de intelectuais e que visava estruturar uma política nacional de formação de professores alfabetizadores e reorganizar o sistema educacional brasileiro ${ }^{43}$. Com Anísio Teixeira como Diretor Geral da Instrução Pública do Distrito Federal ao mesmo tempo em que Fernando de Azevedo ocupava o mesmo cargo em São Paulo, foi possível colocar em prática as diretrizes do Manifesto através dos novos Códigos de Educação.

Uma das principais mudanças do novo Código de Educação foi a de determinar que os professores que ministrariam aulas no curso ginasial (secundário) tivessem também um preparo especial que até então só era exigido para aqueles que se direcionavam ao curso primário, que era o ensino Normal. A partir daquele momento exigia-se dos professores para o curso secundário a formação no recém-criado Instituto de Educação, escola de nível Superior que passava a ser responsável pela formação de professores, ficando responsável também por administrar o Curso Normal. O Instituto passou a ocupar o edifício da Escola Normal, que estava em sua nova sede na Praça de República desde $1894^{44}$.

Com a fundação da Universidade de São Paulo, o Instituto de Educação foi incorporado a ela, e Fernando de Azevedo foi o seu diretor entre 1934 e 38. Segundo o plano de ensino, os alunos que se candidatassem a ser professores no ensino secundário, realizavam parte de sua formação das disciplinas específicas junto à Faculdade de Filosofia, "que se mantinha ainda dentro de sua finalidade estritamente cultural e científica" ${ }^{45}$, e na seqüência cursavam a formação pedagógica no Instituto de Educação. Em seu projeto, a formação adequada de um professor era justamente o resultado do estudo nessas duas instituições, cada uma com sua contribuição específica. Assim, em 1937 formou-se a primeira turma de professores aptos a lecionar no ensino secundário, que haviam cursado o Instituto de Educação.

$\mathrm{O}$ Instituto de Educação e a FFCL dividiam o mesmo edifício. Até mudar-se para a Rua Maria Antônia, em 1949, os cursos da FFCL estavam distribuídos em alguns imóveis no centro da cidade. As ciências humanas, assim como a administração da Faculdade, ocupavam o terceiro pavimento do edifício da Escola Normal à Praça da República, que havia sido acrescido em 1935, e participava ativamente da vida cultural da região; o curso de Física ocupava uma casa na Rua Brigadeiro Luís Antônio, e os cursos de química e biologia, na Alameda Glete.

43 Entre os que assinavam esse manifesto estavam, além do próprio Fernando de Azevedo, Anísio Teixeira e Julio de Mesquita Filho. Azevedo, op. cit., p.675-678.

44 Azevedo, op. cit., pp. 752-753

45 idem, ibidem, p.752. 
Apesar de todo esse esforço de reestruturação do ensino secundário, o Instituto de Educação foi extinto pelo Governo Vargas em 1938, e a formação pedagógica foi incorporada a FFCL, como uma Seção de Educação, e um curso de Didática. Na estrutura de funcionamento da escola, essa incorporação causou uma série de conflitos, com a adaptação necessária de cargos e cátedras para absorver os professores do antigo Instituto. Além disso, o conflito se estendia ao curso de Didática [que corresponde a modalidade que hoje é conhecida como Licenciatura], que já era lecionado naquela escola mesmo antes da junção com o Instituto. Esse curso, de um ano, era ministrado após a conclusão do cada curso específico, para os que se interessassem em lecionar no ensino secundário ${ }^{46}$, era voltado apenas à formação dos que quisessem se licenciar.

As divergências entre o curso de Didática e as disciplinas "de conteúdo" se davam a partir da idéia de que o ensino ministrado pelos educadores, era um conhecimento por demais "aplicado", incompatível com o desenvolvimento da pesquisa e do conhecimento, de modo que o curso de Didática sofria de um certo desprestígio de parte do corpo docente e dos alunos da faculdade, pois era considerado o único "curso profissionalizante" da escola. Segundo Bruno Bomtempi, que estudou justamente este conflito, o pensamento corrente era de que, para lecionar determinada matéria só era preciso ter domínio de seu conteúdo, menosprezando as disciplinas pedagógicas; assim, essa idéia produzia um certo tipo de descriminação na qual, principalmente nas carreiras de ciências, tinha-se a impressão de que os que se habilitam ao ensino secundário eram os que não conseguiriam alcançar a carreira universitária: apenas esses se dispunham a cursar o ano de Didática após seu curso regular.

O curso regular de Pedagogia, no entanto, não sofreu esse tipo de discriminação, pois seguia o formato, a mesma organização e compartilhava disciplinas com os outros cursos, por essa razão era considerado um espaço de reflexão e produção "desinteressada" de conhecimento como os outros cursos da FFCL; cada vez mais se percebia a cisão entre os cursos da escola e o curso de Didática, distante até mesmo da própria seção de Pedagogia, e diversas pressões para eliminar a exigência do curso de didática culminaram na redução drástica de sua carga horária através de decreto em $1946^{47}$, reduzindo efetivamente a possibilidade da reflexão acerca da formação dos jovens no ensino secundário a partir de então, o que definitivamente botava fim ao projeto de Fernando de Azevedo, que aspirava a uma formação de professores para todos os graus em sintonia com o pensamento científico.

46 Bruno Bontempi Jr., A incorporação do Instituto de Educação pela FFCL-USP: hipóteses para entender um campo cindido. Trabalho apresentado na $33^{\mathrm{a}}$ Reunião da ANPED/ Associação Nacional de Pesquisa em Educação. Disponível em http:// www.anped.org.br/reunioes/30ra/trabalhos/GT02-2872--Res.pdf. Acesso em 20/01/10.

47 Idem, ibidem. 
Não há dúvidas de que esse conjunto de debates que mobilizavam os educadores no plano nacional repercutiu na formação dos estudantes das primeiras turmas de Pedagogia, engajados na discussão de um plano educacional para o país. No caso de Flavio Motta é comum percebermos a referência - ainda que muitas vezes indireta - a esses debates em diversos de seus escritos: freqüentemente Flavio recupera em seus textos as origens dessa discussão nos ideais republicanos, na relação entre educação das massas e o Estado, entre a formação de professores e a formação universitária, etc. ${ }^{48}$

E além dos debates específicos de sua área de estudos, Flavio Motta se recorda muito enfaticamente das disciplinas que eram ministradas junto ao curso de Filosofia, e da presença dos professores franceses, que ainda eram naquele momento, quase dez anos depois, a principal referência da escola e uma grande influência.

0 primeiro grupo, que participou da montagem da Faculdade, havia chegado à Universidade em 1934. Formado por professores titulares já reconhecidos na França, permaneceram por um período curto e inauguraram as cadeiras de cada curso. No ano seguinte, em 1935, uma nova leva de professores, em geral mais jovens e com menor experiência, estabeleceu-se a partir de contratos que teriam 3 anos de duração ${ }^{49}$. Neste grupo estavam, entre outros, Lévi-Strauss, Braudel, Monbeig e Maugué; alguns deles tiveram seus contratos renovados em 1938 e ainda lecionavam na instituição quando Flavio Motta foi aluno. Particularmente Jean Maugué, professor da cadeira de filosofia, é constantemente citado como uma referência fundamental entre os estudantes naquele período, e é também mencionado com recorrência por Flavio Motta nas suas lembranças do tempo de aulas na faculdade, como um de seus professores mais importantes.

Na pesquisa de Heloísa Pontes a respeito dos críticos do Grupo Clima, a autora recolheu alguns depoimentos de ex-alunos sobre Maugué; apesar de se tratar de estudantes formados alguns anos antes de Flavio Motta, ainda assim são contribuições importantes para conseguirmos capturar o ambiente e o modo de ensino naquela escola, e pensar as possíveis influências que essas aulas tiveram para os estudantes de Pedagogia, que estavam ali para formar-se professores. Um exemplo é o depoimento de Gilda de Mello e Souza sobre as aulas de Maugué:

“Maugué não era apenas um professor - era uma maneira de andar e falar, que alguns de nós imitávamos afetuosamente com perfeição; era um modo de abordar

48 Retomaremos essa questão mais adiante, ao apresentar a produção escrita de Flavio Motta. 0 texto da revista Zodiac que analisamos no segundo capítulo é um desses exemplos.

49 Fernanda Peixoto, Estrangeiros no Brasil: a missão francesa na Universidade de São Paulo. Dissertação de mestrado, UNICAMP, 1991, pp.14-15. 
os assuntos, hesitando, como quem ainda não decidiu por onde começar e não sabe ao certo o que tem a dizer; e por isso se perde em atalhos, retrocede, retoma um pensamento que deixara incompleto, segue as idéias ao sabor das associações. Mas esse era o momento preparatório no qual, como um acrobata, esquentava os músculos; depois, alçava vôo e, então, era inigualável" 50

Para a autora, "a abertura desse professor francês para tratar os temas mais diversos sob uma forma filosófica" e para estimular nos alunos a reflexão a partir dos acontecimentos do dia-a-dia, das outras leituras, das idéias política, etc. foi um ponto central para os membros do Grupo Clima, que acabaram não sendo filósofos estrito senso, mas sempre se utilizaram "da filosofia e da sociologia para pensar a vida cotidiana"51.

O campo de atuação cultural desse período, marcado por essa mudança no modo de atuação dos críticos e da especialização da crítica de arte, vê a desaparecer a figura do intelectual que transita por várias frentes de atuação, que intercala a crítica e a criação artística, cujo maior expoente havia sido Mario de Andrade ${ }^{52}$. Ao longo da década de 40, a nova geração de críticos começa a transformar a crítica de arte em matéria especializada, feita a partir uma formação intelectual específica, fruto do desenvolvimento das ciências humanas, da estruturação dos cursos universitários, da profissionalização do trabalho jornalístico e da recepção do público urbano à escrita jornalística. A primeira turma da Faculdade de Filosofia formou-se em 1938, sendo a primeira geração de intelectuais que pleiteava a produção de conhecimento científico sistematizado. Inauguraram uma tradição de estudos acadêmicos, e posteriormente ocuparam os cargos de docência nessas mesmas instituições ${ }^{53}$.

Um pouco antes de concluir o curso de Pedagogia, Flavio Motta conheceu Pietro Maria Bardi e Lina Bo, e aproximou-se do grupo que estruturava a montagem do Museu de Arte de São Paulo através de Quirino da Silva. Bardi, auxiliado por Frederico Barata, havia organizado o projeto do novo museu a partir de um projeto que, ao mesmo tempo que se dizia ser um museu "de arte; nem clássico, nem moderno, sem adjetivos", contava com uma concepção institucional segundo as tendências internacionais mais recentes; que priorizava, mais do que a conservação de um acervo, sua difusão - através do ensino e da presença ativa na cidade. Sobre as origens desse modelo de atuação, Renata Motta, que estudou esse projeto institucional em sua pesquisa de mestrado, observa:

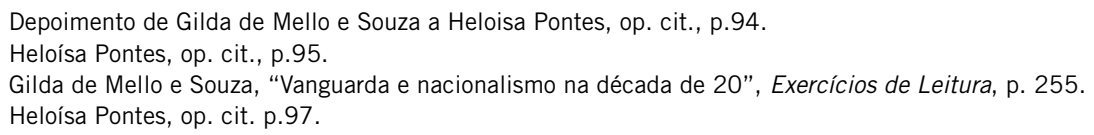


"O Museu de arte de São Paulo, no que se refere ao seu acervo, não nasce com um caráter desafiador, como combatente direto das políticas conservadoras dos museus tradicionais. Nesse período, localizamos o MOMA de NY, fundado em 1929, como a grande referência da inovação no campo museológico e museográfico do pós-guerra. $O$ recorte radicalmente moderno do acervo das suas fundadoras e do projeto museológico do seu primeiro diretor Alfred Barr Jr. [que compõe uma coleção múltipla, agregando produções tão diversas como pintura, escultura, artes gráficas, arquitetura e cinema, com uma proposta de acervo contendo prioritariamente obras modernistas], é muito distinta do nosso museu de arte, cujo núcleo moderno concentrase no Impressionismo francês. No entanto, encontramos ressonâncias do projeto do MOMA-NY nas ações propostas pelo plano museológico delineado por P. M. Bardi A idéia de criar um centro cultural, atingindo e educando um público ampliado, retoma a ênfase dos departamentos não curatoriais - biblioteca, publicações, exposições itinerantes, educativo - propostos por Barr no museu de NY." ${ }^{54}$

Com este projeto, o Museu ocupou metade do segundo andar em um edifício projetado por Jaques Pilon, destinado a ser a sede dos Diários Associados, na Rua 7 de Abril, inicialmente ocupando uma área de $1000 \mathrm{~m} 2$, que se encontrava ainda em construção. A adaptação do espaço foi realizada por Lina Bo Bardi. Seu projeto organizava a disposição do museu: pinacoteca [sala para exposição do acervo], um espaço destinado às exposições didáticas de história da arte, uma sala para exposições periódicas e um auditório, programa mais condizente com um "organismo de difusão cultural" do que com um museu no sentido tradicional de "abrigo de obras de arte" 55.

Desde o início do funcionamento do museu, o projeto de constituição e exposição do acervo dividiu as atenções com um conjunto de mostras periódicas, que tinham uma função específica dentro do conjunto de atividades desenvolvidas pelo museu. Bardi descreve suas variações no catálogo publicado na primeira exposição do acervo do museu na Europa, em 1953. Segundo ele, as mostras periódicas seriam de três tipos: as retrospectivas, dedicadas a "personalidades ou a temas específicos" consagrados no meio cultural, as bimensais, que mostravam o trabalho de jovens artistas, que a cada 15 dias exibiam cerca de 30 obras, e por último as mostras didáticas, que tinham como objetivo comentar determinadas épocas ou escolas, a partir de "extenso material iconográfico", composto por fotografias de obras, reproduções, gráficos, quadros explicativos, etc ${ }^{56}$.

54 Renata Motta, O MASP em Exposição: mostras periódicas na 7 de abril. Dissertação de Mestrado, FAUUSP, 2003, p.21. 55 Idem, ibidem, p.22.

56 P. M. Bardi, apud Renata Motta, op. cit., p.23. 
Tendo como objeto de pesquisa especificamente essas mostras, Renata Motta, destaca o fato de que é possível percebermos através das mostras periódicas os debates em torno dos interesses institucionais: elas representavam essencialmente a idéia do "museu vivo", eram um "laboratório de elaboração e de discussão dos problemas artísticos, procurando indicar caminhos de compreensão no campo da arte"57, era através dessa dinâmica das exposições periódicas que se rebatia a idéia do museu tradicional, que se restringia ao armazenamento das obras. Entre 1947 e 1957, o período estudado pela autora, foram realizadas quase cem mostras periódicas. Em conjunto com os cursos livres e aqueles organizados pelo IAC, se acentuavam as ações educativas próprias ao projeto de Bardi, de um museu de acordo com a vida moderna, em sintonia com o debate museológico internacional daquele momento, que voltava às instituições ao público não-especializado e centravam esforços de seu potencial educativo. ${ }^{58}$

Entretanto, quando confrontado com o acervo, o projeto institucional causa um certo estranhamento, pois o acervo recolhido parece partir de uma tendência à selecionar uma "história da arte mais conservadora", à medida em que ratifica artistas consagrados do passado. Ao mesmo tempo, através de seu projeto educativo e das exposições periódicas, o museu está "sem dúvida aberto para as manifestações do moderno", promovendo o desenho industrial, a propaganda, as "artes virgens", a arte popular e a vanguarda arquitetônica. ${ }^{59}$

A programação dessas mostras, especialmente durante os primeiros dez anos de funcionamento, estava afinada com as principais tendências da vanguarda internacional naquele momento, como podemos perceber, por exemplo, através das mostras de Alexandre Calder e Max Bill, ou então da programação voltada a arquitetura contemporânea.

Flavio Motta participou ativamente da concepção, organização e montagem de diversas das mostras periódicas e freqüentemente era responsável também por acompanhar os artistas que vinham à cidade apresentar seus trabalhos no museu, como foi o caso de Max Bill. Flavio Motta realizou a montagem da mostra de Max Bill pessoalmente, auxiliado por Alexandre Wollner, então aluno dos cursos do museu, e acompanhou o artista e arquiteto suíço durante sua temporada em São Paulo. Não é difícil imaginar a influência desse tipo de contato para um jovem artista, e também a desenvoltura que ele conquista no meio artístico ao estabelecer contato direto com visitantes tão ilustres quanto Steinberg, Neutra, Bill, representantes das tendências mais avançadas da vanguarda internacional.

57 P. M. Bardi, apud Renata Motta, op. cit., p.24.

58 Renata Motta, op. cit., pp.90-91.

59 Idem, ibidem, p.97. 
Em 1950 a área do museu foi ampliada, com o final das obras do edifício, passando a ocupar mais três pavimentos. O destino principal desta ampliação foi abrigar um novo programa: a criação do Instituto de Arte Contemporânea (IAC), projeto que formalizava, efetivamente no formato de uma escola, todas as iniciativas que vinham sendo desenvolvidas no sentido de afirmar o caráter pedagógico do museu que Bardi vinha promovendo desde o início de seu funcionamento.

De fato, inúmeras ações educativas, de certo modo desconectadas, sempre foram empreendidas em torno das atividades do museu, e é principalmente nestas atividades que Flavio Motta se envolve, o que reforça nossa idéia de que seu interesse principal sempre foi em torno de um projeto educacional.

Desde sua inauguração o Museu abrigou a Exposição Didática de História da Arte. Apesar de representar um material fundamental para a compreensão dessa proposta educativa do museu, não há muitos registros de seu conteúdo e organização. Sabemos que ela ocupava um espaço próprio dentro do museu, distinto da área reservada às demais exposições periódicas, e segundo Renata Motta, foi concebidas a partir da experiência prévia de Bardi no Studio d'Arte Palma ${ }^{60}$ - que teria cedido o material para a primeira exposição, e que se relacionam diretamente com iniciativa semelhante organizada por Alfred Barr no MOMA ${ }^{61}$.

Flavio Motta conta que os painéis chegaram prontos da Itália, porém ele não sabia exatamente qual era a procedência nem quem os havia confeccionado. No período que antecedeu à abertura do Museu, Flavio e os outros monitores foram encarregados de confeccionar a versão dos painéis traduzida para o português. Segundo seu depoimento, a Exposição Didática tinha como alvo principal o público escolar. Era composta por uma seqüência de 84 painéis que explicavam a partir de textos e reproduções fotográficas das obras, as principais tendências, as escolas, as sucessões de acontecimentos e as características técnicas de algumas das modalidades artísticas: era, segundo Flavio, um panorama da história da arte desde a pré-história ${ }^{62}$. Antes da inauguração, durante a instalação do Museu no edifício e com o local ainda em obras, Bardi ministrou um curso de História da Arte voltado à preparação dos monitores que atenderiam ao público. Diversos artistas que mais tarde lecionariam no museu freqüentaram este curso, como Bonadei, Mario Gruber, Marcelo Grassmam, Aldemir Martins, além dos cinco monitores: Flavio Motta, Nydia Licia, Enrico Camerini, Renato Czerna, Gabriele Bochardt63. Flavio Motta foi o único dos

60 Renata Motta, op. cit. p.23.

61 Sobre a atuação de Barr no Moma ver BARR, Margaret Scolari. "Our Campaigns: Alfred H. Barr, Jr., and the Museum of Modern Art: A Biographical Chronicle of the Years 1930-1944." The New Criterion, 1987, pp. 23-74.

62 Segundo depoimento de Flavio Motta a autora.

63 Segundo depoimento de Flavio Motta; em alguns textos de Bardi consta também o nome de Jorge Wilheim. 
1. Bardi no curso de História da Arte para os monitores do museu. Flavio Motta está a esquerda de Bardi, com o bloco de anotações.

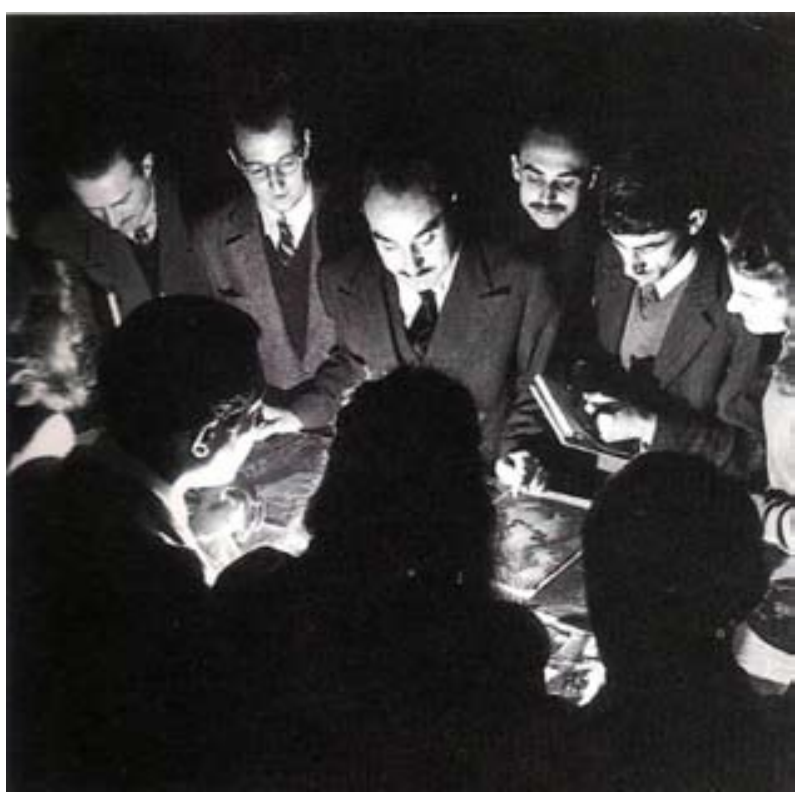

monitores que permaneceu no MASP por um longo tempo, primeiro como assistente de Bardi e mais tarde, como coordenador dos cursos do IAC. ${ }^{64}$

0 curso de história da arte para os monitores e o interesse do público na exposição didática parecem ter sido um ponto de partida para que se botasse em prática o projeto do "museu vivo"65. A partir deles tem início uma série de cursos e um extenso programa de conferências que começam a ser ministrados no museu, e que certamente representam um embrião daquele que viria a ser o Instituto de Arte Contemporânea. Ao que parece, no entanto, nos anos iniciais não se tinha muita clareza de qual seria seu foco, ou seu programa específico.

Entre os diversos arquitetos e artistas renomados que ministraram os cursos do Museu de Arte, especialmente um deles merece destaque, não somente pela qualidade de sua produção, mas também por ter se tornado muito próximo de Flavio Motta: Roberto Sambonet, pintor, designer e artista gráfico italiano. Sambonet chegou ao Brasil em 1948, possivelmente convidado pelo próprio Bardi, e foi trabalhar no Museu. Havia estudado pintura, iniciado (e logo depois abandonado) o curso de Arquitetura na Politécnica de Milão, e vinha desenvolvendo um trabalho como pintor iniciante na Itália, tendo participado de algumas exposições. Sua experiência no Brasil, ainda que tenha sido uma temporada breve, é considerada um período crucial em sua carreira. Segundo Enrico Morteo, trata-se de uma "viagem de formação" no

64 P. M. Bardi, História do MASP. São Paulo: Empresa das Artes, 1992. p.38.

65 Uma parte importante desse projeto do Museu era representado pela revista Habitat, sobre a qual trataremos no capítulo seguinte 


\section{IONIITORES PARI O "IILSEL DE ARTIE"}

\section{Texto de ARLINDO SILVA $\because$ Fotos de PETER SCHEIER}

SAO PAULO - Setembro.

$\mathrm{A}^{\mathrm{S}}$ obras do edifício onde serăo instalados os "Diárlos Associados" de Sáo Paulo estấo em indamento. O prédio, que terá dezesseis andares, esta todo revestido de tapumes, e lá dentro dezehas de operários trabalham, de dis e de noite, rerezando-se, para que dentro de ano e meio, no máximo, tudo flque pronto. O engenheiro Jacques Plicn, que fol encarregado da construçăo, deu, portm, um toque de urgencla ao trabalho, de sort que ja agora val ser inaugurado o-Mugeu de Ar$e^{-}$, que ocupa très salóes no segundo andar do arranha-céu. Constltuem, no momento, património artistico incalculável do museu, cerca de einquenta quadros famosos, doados pelo que há de mals expressivo nos meios industriais, financeiros, intelectuals e socials de Sấo Paulo. Com efeito, Museu năo será uma realizaçáo ûnicamente local, únicamente paulista. Nấo será tampouco apenas nacional. Terá projeçăo internacional. Alnda ha

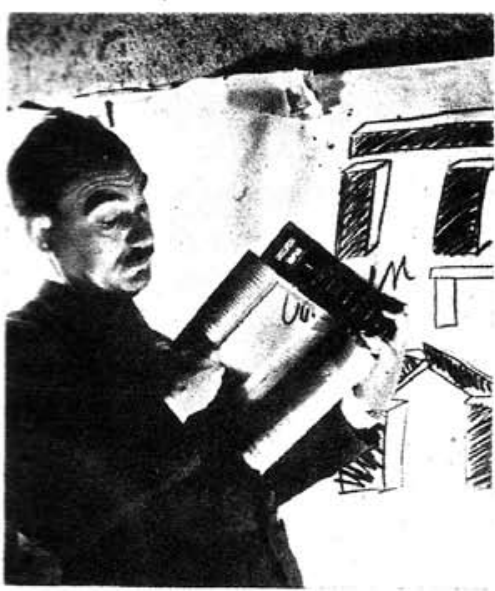

AS LIÇÓES COMEÇAM pelas primeiras srquiketuras. $E^{\prime}$ o homem aprendendo a colocar uma arquitrave de pedra sôbre duas outras pedras verticais. E' O princedra sobbre duas outras pedras verticais. E' o' principio pelo guals a moso mumento da humanidade

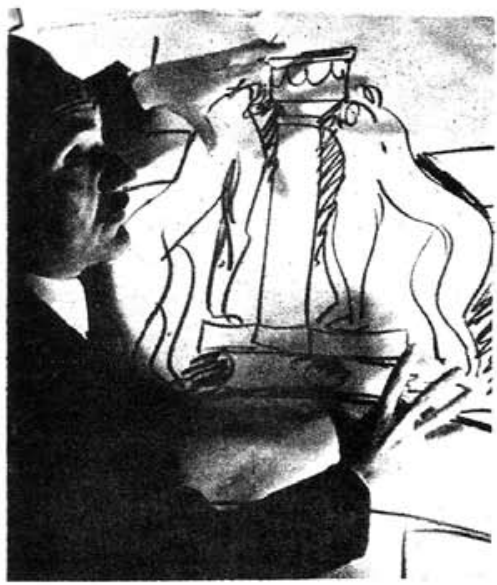

"EIS A PORTA dos Leỏes, em Micene". Bardi. a bescreve com lembranças pessoais. "Estive lá, certa descreve com Corbusier e Fernand Léger. E' uma das vez. com Corbusier e Fernand. Eéger. É uma das desenho auxilia a explicaçáa pedagógica.

20 de Setembro de 1947 pouco a pintora Moussia Pinto Alves, viajando pelos Estados Unidos, testemunhou o interèsse dos peras de concretizar-se em Sso Paulo peras de ning seja simplesmente us uário, onde se Golem obras de inestimável valor de El Greco, Goya, Boticelli, Magnasco, Portinari ou Almeids Júnior, Há de ser um "museu vivo", no qual os visitantes sejam orientados com seguranca, e iniciados no conhecimento fundamental da arte, em suas manifestaç̄es originais, dentro da História. $\mathrm{E}^{\prime}$ por isso que se preparam, atualmente, os futuros orientadores, a bem dizer monitores, do Museu. $\mathrm{E}$ eis por que aparece aqui esta reportagem.

Na sala do primeiro andar do ediriclo associa do, onde seŕ instalada futuramente a sucursal paulista de O CRUZEIRO, ainda com barras de aco a mostra, paredes com brechas por tapar,

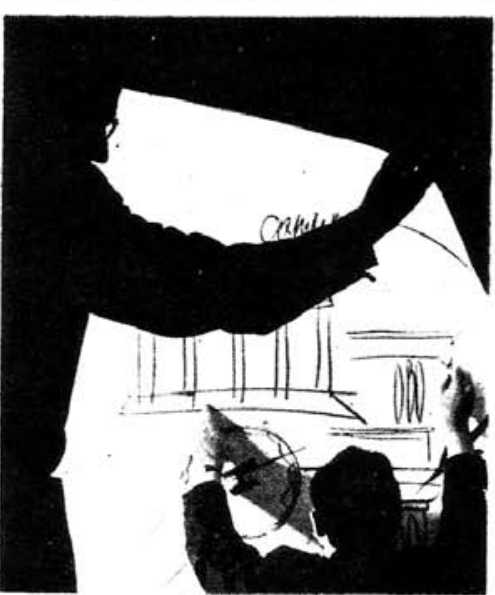

- Professor Bardi, perante seu auditorio, constituido por artistas, arquitetos o desenhistas, num esbòco rapidissimo, mostra como é construido um templo. - que é um capital, para que serve, como se compöe. E' conciso e sempre claro
E

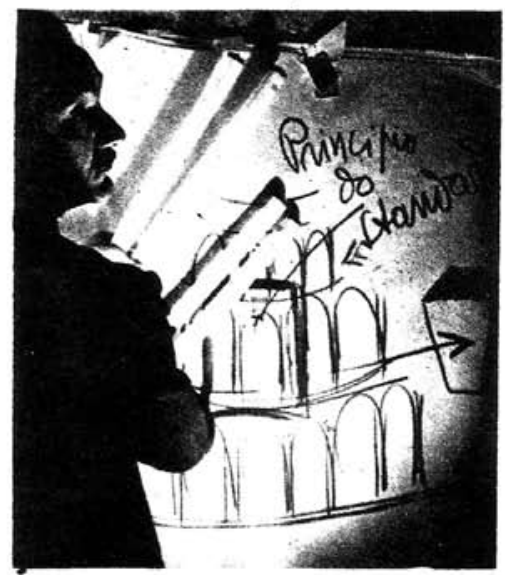

NA SALA IMPROVISADA do edificio em construçào, a professor utiliza tubos fluerescentes para suas ex plicaçōes: "O standard nono nasceu agora - é uma idéi muito antigas e pode-se encontrar o seu exemplo na construçào do Coliseu de Roma". montes de cavacos pelos cantos, esté funcionando atualmente a escola preparatoria para os futuros monitores do Museu, Dirige- 0 historlador e critico de arte, P. M. Bardi que os "Dírios Aseociados" foram buecar ma Ithlin para dirigir o Muciados" foram buscar na Italia para dirigir o Mu ceu. E' uma figura de renome, ex-presidente do "Estudio de arte de Parma", e ex-diretor ds "Galeria de arte de Roma". A éle está confiada a tarefa de organizar o Museu. Mas como éste nā deve ser apenas uma coleçăo de grandes obras, mas o "museu vivo" de que já falamos, o Pror. Bard prepara os seus futuros assistenies. De um grupo numeroso de artistas e desenhistas, êle va escolher, depols de um curso intensivo, os cinco ou seis que văo ser os instrutores do público. Náo hấo de ser uns simples cicerones, que repitam, an após ano, as mesmas descriçóes, os mesmos "slogans". Os monitores deverăo saber explicar a pcvo, dentro do Museu, a distinçấo entre um véu de "Madonna" do século XVI e um do Século XVIII, bem como os tracos

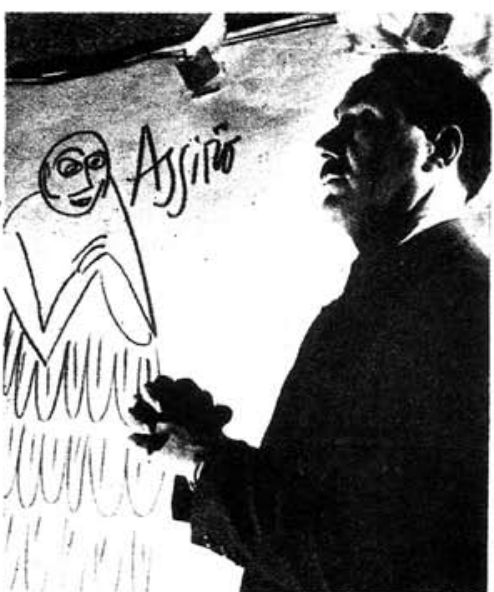

QUANDO a simples desenho não é suficientemento expressivo, Professor Bardi utiliza a mimica para se faxer entender. Aqui se transforms em estátua para ilustrar o esquema que sa vê na parede, onde osquema que se vê na

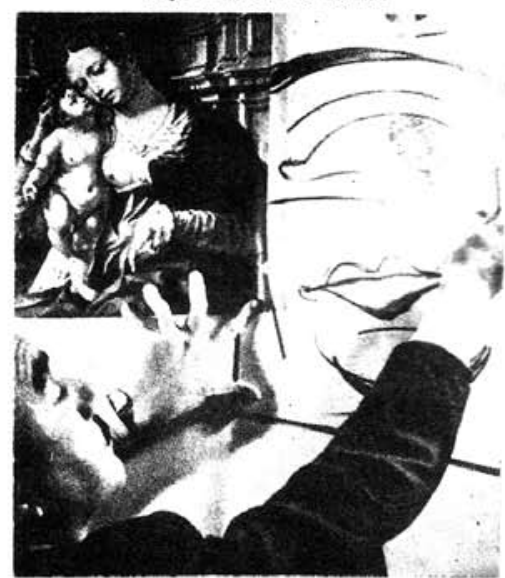

A aula continua no segundo andar do editicio do "Diários Associados" em São Paulo: "Mabuse é um pintor da Europa setentrional. Vem trabathat no Srasil, sofre por sus vez influências". O tems de complicado mas à altura dos alunos. 
sentido mais clássico, pois representou um momento de virada e de maturidade profissional em sua trajetória: "Sambonet retorna do Brasil transformado: partiu como um jovem pintor, retorna artista, projetista, designer". ${ }^{66}$ Logo após retornar a Itália em 1953, começa a trabalhar na fábrica de objetos em aço inoxidável que pertencia a sua família, onde tem a oportunidade de desenvolver ao mesmo tempo um trabalho de designer e artista gráfico, e onde realiza durante os anos seguintes uma série de experiências de moldagem de peças no projeto de objetos. Com eles, recebe uma série de importantes prêmios de design na Itália nos anos seguintes, e tornase um dos mais importantes designers do período ${ }^{67}$. Nesta mesma época, torna-se diretor de arte da revista Zodiac. É Sambonet quem sugere a Bruno Alfieri, editor-chefe da revista, o nome de Flavio Motta para o ensaio sobre o Brasil no número especial lançado em 1960.

Segundo a pesquisadora Ethel Leon, cuja dissertação de mestrado trata do IAC ${ }^{68}$, as primeiras iniciativas educativas do museu foram um clube de arte para crianças, um curso de história da arte para estudantes de ginásio e colégio, que atribuía bolsas de estudo na Europa para os que se destacassem, cursos para estudantes universitários, cursos para associações, escolas etc. No entanto, ainda que essas iniciativas tivessem um bom público, decerto sentiase falta de uma formação mais continuada e ao mesmo tempo mais especializada. Segundo ela, em 1948 Bardi dá início a um projeto de fundar uma escola destinada a formar um quadro especializado em teoria e história da arte, voltado principalmente ao trabalho nos museus ${ }^{69}$.

A partir da documentação do arquivo, ela relata que Bardi planejou esta escola durante 1948 e 1949, e a partir da lista de professores que ele gostaria de convidar para lecionar, é possível percebermos que a proposta era a de um curso de história da arte que contava com colaboradores de diversas especialidades, o que pressupõe uma visão muito particular da história da arte, mais abrangente e ligada ao cotidiano. A lista continha antropólogos, artistas, arquitetos, críticos de arte, educadores, como Ferraz, Lourival, Quirino da Silva, Anísio Teixeira, Darcy Ribeiro, Thomas Farkas, Luis Saia, Rodrigo de Mello Franco, Gilberto Freyre, Pierre Verger, Bazin, entre outros. E como observa a autora, alguns nomes também eram ligados ao Museu de Arte Moderna, como Lourival Gomes Machado e Wolfgang Pfeiffer ${ }^{70}$, o que pode ser entendido como mais uma das indicações de que a rivalidade entre os dois museus talvez não fosse tão acirrada a ponto de prejudicar os interesses culturais de cada uma das instituições.

66 Enrico Morteo (org.), Roberto Sambonet, designer, grafico, artista (1924-1995). Milão: Officina Libraria, 2008, p.28.

67 Idem, ibidem, pp.262-265.

68 Ethel Leon. IAC Instituto de Arte Contemporânea, Escola de Desenho Industrial do MASP (1951-1953) - Primeiros estudos. Dissertação de mestrado, FAUUSP, 2006. A pesquisa de Ethel Leon desenvolveu-se principalmente a partir de pesquisas no arquivo do MASP, de onde provém a maior parte das informações de conteúdo e atividades que a pesquisadora reuniu.

69 Leon, op. cit. p.18.

70 idem, ibidem, p.20. 
No entanto, este projeto de uma escola voltada aos historiadores da arte, ainda segundo a pesquisa de Leon, é a partir de um certo momento deixado de lado e dá lugar ao Instituto de Arte Contemporânea, iniciativa que, ainda como projeto, não havia definido seu foco: ora era descrito como sendo fruto da reunião de todos os cursos que eram ministrados pelo museu naquele momento [desenho, fotografia, gravura, a escola de propaganda e os cursos para crianças], ora ele seria especificamente uma "escola de design".

Pouco tempo depois, o programa do IAC é definido e se abrem inscrições para seu curso: ele é anunciado como uma escola de desenho industrial. 0 documento que anuncia a criação da escola explica melhor estes objetivos:

“O Desenho Industrial no Brasil ainda está para ser feito e enormes possibilidades defrontam-se para todos aqueles que, dedicando-se a este ramo de atividades, saberão acompanhar o espírito nitidamente contemporâneo de nossa época adaptando as mesmas linhas estéticas das artes puras as assim chamadas artes aplicadas e criando uma correspondência de valores estéticos entre umas e outras de forma que a atividade das primeiras não continue desprendida das necessidades e utilidades diárias da vida prática, mas engendre uma visão de conjunto harmoniosa de todas as artes dentro de uma concepção orgânica. [...] decidiu o Museu criar um Instituto de Arte Contemporânea que funcionará com caráter essencialmente didático destinandose a formar técnicos em assuntos como cerâmica, artes gráficas, tecelagem, metais, mobiliário, bordados, esmaltes, jardinagem, desenho, pintura e plástica em geral adaptados para fins industriais.[...] Não visa a escola criar artistas, mas sim orientar os jovens com uma preparação técnica e artística bem dirigida, no sentido de darIhes a possibilidade de trabalhar, criar e contribuir para o incremento da indústria em geral entro de um espírito e um gosto apuradamente contemporâneos."

A equipe que assina a publicação do documento, que seria a congregação dessa escola, indica que o curso - em relação à proposta anterior do curso de História da Arte - deixou de incorporar as contribuições de tantas áreas do conhecimento, para focar-se na "preparação técnica e artística bem dirigida", ministrada essencialmente por professores vindos da arquitetura e das artes plásticas ${ }^{71}$; além desse programa, também Bardi complementa a apresentação da escola:

71 Os seguintes membros compõe assinam o documento: Lasar Segall, Eduardo Kneese de Mello, Roberto Burle Marx, Lina Bo, Oswaldo Bratke, Rino Levi, Gian Carlo Palanti, Elizabeth Nobiling, Alcides da Rocha Miranda, P.M. Bardi, Thomaz Farkas e Jacob Ruchti. in Leon, op. cit. p.34. 
"formar jovens que se dediquem à arte industrial e se mostrem capazes de desenhar objetos nos quais o gosto e a racionalidade das formas correspondam ao progresso e à mentalidade atualizada, aclarar a consciência da função do desenho industrial refutando a fácil e deletéria reprodução de estilos e o diletantismo decorativo; ressaltar o sentido da função social que cada projetista, no campo a arte aplicada deve ter em relação à vida. Em uma palavra, o IAC, solicitando a colaboração definitiva da indústria, deseja incrementar a circulação de idéias novas, de novos empreendimentos no campo estético, erroneamente considerado "torre de marfim" para iniciados, generalizando o mais possível as conquistas da arte, da tradição e da cultura. ${ }^{\text {"72 }}$

Nesse mesmo documento, é apresentado o programa da escola, composto por três ciclos: o aluno ingressava num curso preliminar, que era obrigatório a todos os alunos e apresentava uma visão geral das questões; na seqüência, escolhia qual seria seu curso especializado, em que o aluno definia o campo a seguir [ao que tudo indica, entre os assuntos apresentados anteriormente], e por fim, caso houvesse interesse, poderia cursar outras disciplinas, no chamado curso complementar, que era facultativo. Os candidatos ao curso do IAC deveriam passar por um processo seletivo para ingressar na escola, que segundo depoimento de Alexandre Wollner à pesquisadora Ethel Leon, ex-aluno da escola, não privilegiava alunos com formação acadêmica regular: dava-se mais ênfase à experiência profissional, à habilidade técnica e ao interesse intelectual. Como ele mesmo ressalta, nesse sentido sua proposta se aproximava daquela da Escola de UIm, que "podia ser freqüentada por um marceneiro"73.

Flavio Motta lecionou História da Arte no IAC, num curso em que dividia as funções com Bardi. O IAC foi a primeira escola onde Flavio lecionou essa disciplina, que viria a assumir posteriormente na FAUUSP. E é provável que tenha sido também através do IAC que ele estabeleceu um contato mais aprofundado das questões da arquitetura, pois este era um tema bastante presente no curso.

A hipótese de Ethel Leon para esta aproximação do curso do IAC com a arquitetura era a de que, tendo a Bauhaus como modelo, o projeto do IAC acreditava que a arquitetura representava a união de todas as artes, no entanto, a procura de um lugar próprio de intervenção, a escola havia optado por não interferir diretamente no campo da arquitetura, concorrendo com as escolas recém-criadas na USP e Mackenzie, ainda que tentasse manter a proximidade dos seus temas ${ }^{74}$.

72 P.M. Bardi, Programa para o IAC, apud Ethel Leon, op. cit., p.35.

73 Depoimento de Alexandre Wolner a Esther Leon, op. cit. p.38.

74 Ethel Leon, op. cit., p.108. 
Dentro do programa para os cursos de especialização, seriam oferecidos cursos diretamente relacionados à formação dos arquitetos, como "Evolução do concreto armado" ministrado por Pier Luigi Nervi, "Arquitetura dos Jardins", por Roberto Burle Marx, "Acústica na Arquitetura" por Rino Levi, etc. Os arquitetos representavam boa parte do corpo docente da escola e sua congregação, e a aproximação da arquitetura era mesmo declarada nas intenções de trabalho: "Pretende o Instituto acentuar o espírito de pesquisa no terreno da arquitetura, urbanismo e artes aplicadas, principalmente no setor industrial" ${ }^{75}$. E ainda, podemos reconhecer este desejo de aproximação da formação dos arquitetos, franqueado no discurso de que tudo pertence ao campo da arquitetura, na explicação de Jacob Ruchti sobre a estrutura do curso:

\begin{abstract}
"As cadeiras da $1^{\text {a }}$ fase, formam um curso fundamental, que tem muita analogia com um curso de preparação básica para arquitetos - e nesse contexto vale a pena lembrar um pensamento do célebre arquiteto francês - um dos pioneiros da arquitetura contemporânea - Auguste Perret, que disse: "Móvel ou imóvel, tudo que ocupa o espaço - pertence ao domínio da Arquitetura". E, de fato, nesse sentido o desenhista industrial é um arquiteto: ele não projeta prédios, mas projeta rádios, automóveis, geladeiras etc." 76
\end{abstract}

É importante notar que a atuação profissional de alguns dos arquitetos que lecionavam no IAC também tangenciava o campo do desenho industrial, como a experiência de Lina Bo Bardi e do próprio Rutchi, que mantinha a loja de móveis e interiores Branco e Preto. ${ }^{77}$

Ainda que não aspirasse concorrer diretamente com as Faculdades de Arquitetura recém estabelecidas, ao mesmo tempo, o curso do IAC pretendia preencher algumas lacunas que eram notadas nesses cursos no sentido de atualizar a formação, ainda muito vinculada às referências tradicionais dos cursos de Belas-Artes ou das escolas de Engenharia. O propósito do IAC era o de oferecer uma formação mais adequada ao processo de modernização do que aquela que estava sendo oferecida nas escolas, a partir da referência no curso da Bauhaus, modelo que certamente as escolas de arquitetura ainda estavam longe de alcançar. A FAUUSP só se aproximaria deste projeto uma década depois, na reestruturação de seu curso empreendida em 1962.

Não é nosso objeto de estudo o conteúdo específico ou o desenvolvimento do curso do

75 "Instalação do Instituto de arte contemporânea: O belo a serviço da industria - fundamentos no desenho", Diário de São Paulo, 8 de março de 1950, in Leon, op. cit. p.108.

76 Jacob Ruchti, O Curso de Design do Instituto de Arte Contemporânea. Habitat no. 3, São Paulo, 1951, p.62

77 Ethel Leon, op. cit., p.110. 
IAC; o que nos interessa neste ponto é compreender, de um lado, como o IAC representou um espaço privilegiado de debate de certos temas que começam a aparecer neste período e se tornam fundamentais no campo da arquitetura contemporânea, e de outro lado, demarcar o percurso de Flavio Motta através do ensino, ao mesmo tempo, tentando compreender de que maneira certos temas e interesses atravessam essa trajetória.

É importante ressaltar que, em paralelo com o IAC, os cursos livres e as conferências que eram oferecidas continuaram em pleno funcionamento, e muitas vezes as atividades da escola se misturavam com as outras atividades didáticas do museu. No trabalho de Ethel Leon, há diversos exemplos desse intercâmbio - professores dos cursos livres davam aulas no $I A C$, as oficinas ${ }^{78}$ eram divididas entre as duas modalidades, etc.

O curso do IAC teve início em 1951, mesmo ano em que se inaugura a I Bienal de São Paulo, e foi inaugurado no mesmo dia da abertura da exposição de Max Bill no museu. O IAC funcionou por apenas 3 anos, encerrando suas atividades em 1953. Ainda que em alguns depoimentos encontrem-se tentativas de justificar o fechamento do IAC a partir de pequenos problemas, como a falta de apoio financeiro, problemas de espaço físico etc., a razão principal apontada por Ethel Leon foi o desinteresse da indústria pelos designers formados no IAC. De fato, mesmo durante os cursos, a escola tentou aproximar-se da produção industrial e proporcionar experiência prática para os alunos, mas esta tentativa já não havia obtido o resultado esperado. Quando concluíram o curso, a turma que se graduou no IAC não foi absorvida pelo mercado de trabalho. Não é nosso objetivo nesse momento discutir as razões deste desinteresse, certamente vinculadas a um processo de industrialização baseado num modelo que priorizava a reprodução e a cópia dos padrões correntes. 0 que nos interessa é pontuar a experiência pioneira do ensino de desenho industrial no IAC e sua aproximação com a arquitetura, para refletirmos mais adiante acerca da implantação do curso de desenho industrial na FAUUSP, em 1962.

No mesmo ano do fechamento do IAC, o MASP abriu o Curso de Formação de Professores de Desenho, que era dirigido por Flávio Motta. Segundo ele, esse curso teve origem no Curso de Didática ministrado na FFCL. Flavio Motta foi convidado por colegas que lecionavam no curso de Didática, para ministrar um curso de "Desenho didático", no curso de Formação de Professores ${ }^{79}$, junto ao já mencionado grupo de Didática da USP, oferecido aos alunos que buscavam a licenciatura.

78 Havia no MASP o ateliê de gravura, a oficina de tecelagem, um laboratório fotográfico e uma oficina de trabalhos em metal e madeira, onde eram realizadas maquetes.

79 Não encontramos nenhuma evidência de que esse fosse um curso regular dentro do Curso de Formação de Professores, e Flavio Motta nunca foi contratado como professor da FFLC; ao que parece era muito mais uma colaboração entre amigos, um curso complementar, do que de fato oficializado dentro do currículo daqueles que optavam pela licenciatura. 
Conforme depoimento de Flavio Motta, no início, a proposta não era a de um curso voltado ao ensino do desenho, mas sim de auxiliar os futuros professores a usar o desenho como instrumento de ensino de suas disciplinas específicas. Segundo ele, em 1953, Bardi o convidou para ministrar no MASP, entre os cursos livres oferecidos no museu, uma versão semelhante àquele ministrado na Formação de Professores. Ainda que Flavio Motta insista em dizer que a origem do Curso de formação de professores de desenho seja neste curso didático, quando passou a ser oferecido no museu, sua orientação tornou-se outra, afinal, não se tratava mais do desenho didático à reboque das outras disciplinas, mas sim uma abordagem do ensino de desenho como disciplina autônoma.

O principal documento para entendermos o sentido e a importância deste curso é um relatório redigido por Flavio Motta em 1956 que apresenta os propósitos do curso e as atividades que foram desenvolvidas no curso ao longo dos anos anteriores. Este relatório foi feito justamente para informar a FAAP dos detalhes daquele curso que a Fundação estava acolhendo naquele momento.

Segundo consta neste relatório, o curso visava formar professores destinados a lecionar desenho no ensino secundário, pois a formação ministrada pelas Faculdades de Filosofia, Ciências e Letras não eram capaz de dar conta desta demanda que exigia preparo específico. E este preparo era necessário a medida em que

"dia a dia o desenho comparece a nossa percepção, seja entre as determinantes das formas industrializadas, seja no caráter da arquitetura, seja em manifestações espontâneas do espírito criador do povo, seja como linguagem, meio de expressão, tudo enfim faz parte daquilo que se chamou a 'civilização da imagem', ao se apontarem as rápidas transformações da fisionomia urbana em todos os seus aspectos." 80

Preparar professores para ensinar desenho era, nesse sentido, capacitar profissionais a treinar o olhar e a sensibilidade dos estudantes às novas manifestações artísticas e culturais, segundo uma perspectiva adequada à modernidade, que tivessem "uma visão menos acadêmica". E ao mesmo tempo, era preciso que os professores fossem capazes de estimular "as formas criativas" dos estudantes, que acabavam por se perder a medida em que ao se tornarem adultos, acabam por "orientar-se por uma visão de mundo estandardizada: morre assim a vontade de inventar algo no desenho, e aqui começa a grande tarefa do professor, 
1. Flavio Motta conduz grupo de crianças na Exposição Didática

2. Flavio Motta apresentando seu programa Video de Arte, sobre história da arte, na recém-criada TV Tupi.
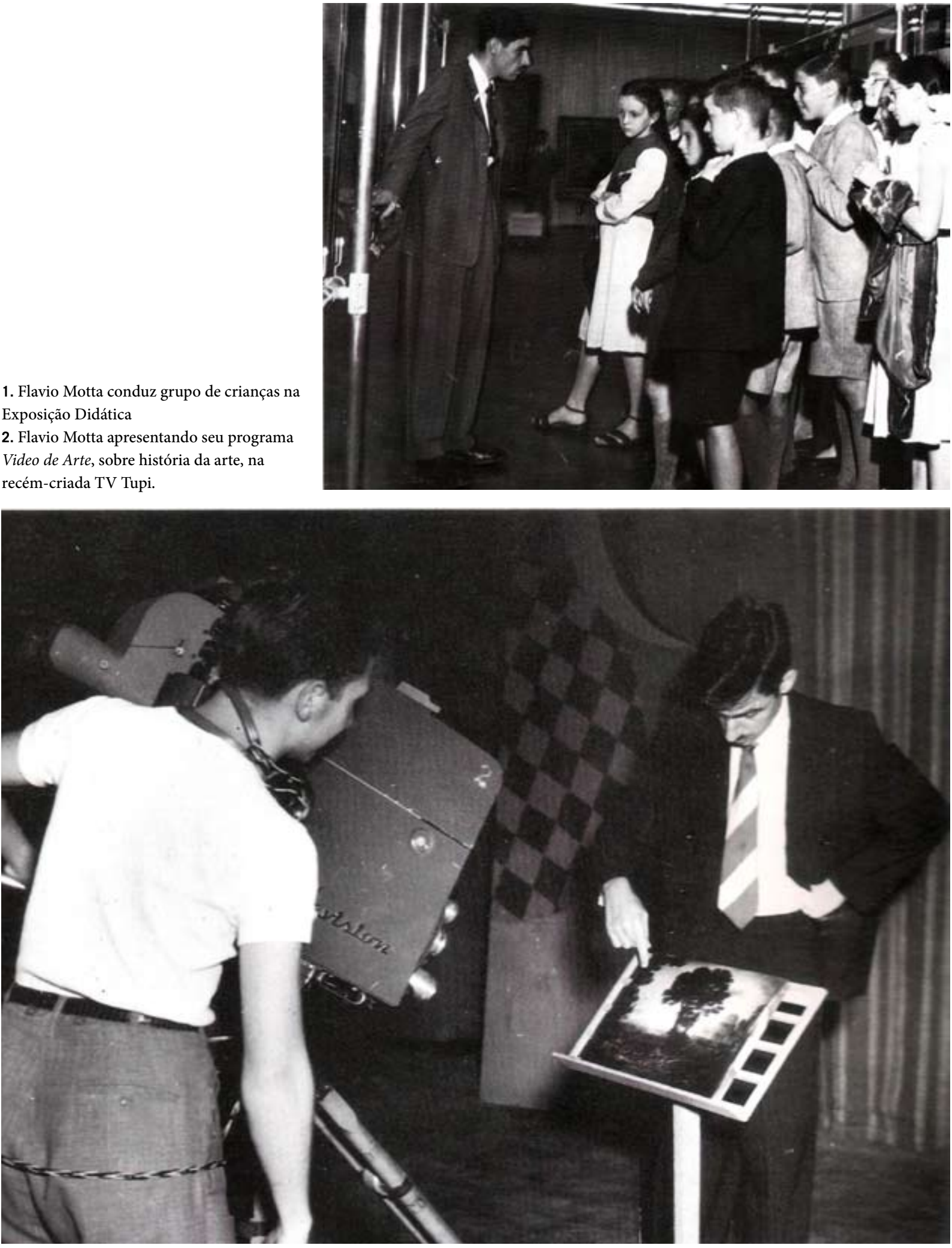
sabendo guiar o aluno para uma nova densidade da atividade criadora, nas bases adequadas a sua idade." 81

Esses anos iniciais do Curso de Formação de Professores de Desenho coincidem com um movimento de desconfiança acerca da autenticidade do acervo do Museu, que geram uma série de boatos, aos quais Bardi responde indiretamente, organizando uma exposição itinerante pelos principais museus europeus, com as obras mais importantes que compunham o acervo do MASP, num total de $64 .{ }^{82} 0$ objetivo era obter a consagração da coleção no ambiente europeu. Bardi e Lina embarcam neste tour acompanhando o acervo do museu. Durante o período de viagem do casal, entre janeiro de 1954 e fevereiro de 1955, Flavio Motta assume temporariamente o cargo de Diretor do Museu.

Após a Europa, o acervo segue então para os Estados Unidos. A aquisição de obras nos anos anteriores, no entanto, havia sido realizada à custa de alguns empréstimos, os quais tinham como credores instituições americanas que solicitaram sua quitação. Segundo Renata Motta, a garantia do empréstimo havia sido a penhora das obras, e por esta razão as obras ficaram retidas durante dois anos nos Estados Unidos, sendo liberadas somente em 1957, quando o museu obteve um empréstimo junto à Caixa Econômica Federal e conseguiu a liberação das obras. Assim que foram liberadas, o Metropolitan Museum of NY recebeu o acervo para uma grande exposição em sua sede.

Nesta ocasião, Lina e Pietro viajaram aos Estados Unidos, porém desta vez Flavio Motta os acompanhou, com o propósito de pesquisar as técnicas de conservação e documentação dos acervos dos museus nova-iorquinos, especialmente do Metropolitan ${ }^{83}$, muito provavelmente em função do acordo firmado para a exposição das obras. Segundo Flavio, ele passou muitos dias visitando e estudando as áreas técnicas dos museus, e estendeu sua estadia um pouco mais do que o previsto, para efetivamente conhecer Nova York, enquanto Lina e Bardi seguiram com a exposição para outras cidades americanas. Durante essa temporada, Flavio Motta foi convidado pelo Professor Frank Tannembaum, historiador responsável pela cadeira de Latin American History na Columbia University, a ministrar uma palestra sobre o Brasil nessa universidade ${ }^{84}$.

81 Idem, ibidem. s/p.

82 Segundo Renata Motta, a exposição percorreu os seguintes museus: teve início no Musée L'Orangerie de Paris [outubro de 1953], seguindo para o Palais de Beaux-Arts de Bruxelas [14 de janeiro a 28 de fevereiro de 1954], Central Museum de Utrecht [6 de março a 2 de maio], o Kunstmuseum de Berna [8 de maio a 7 de junho], a Tate Gallery de Londres [19 de junho a 15 de agosto] e o Kunsthalle de Dusseldorf [29 de agosto a 31 de outubro de 54], tendo sido encerrada no Palazzo Reale de Milão em fevereiro de 1955. p.25.

83 Depoimento de Flavio Motta a autora.

84 Não restou nenhum registro sobre esta conferência. Segundo Flavio Motta, uma carta de agradecimento foi escrita pelo Professor, e anexada a sua documentação na FAUUSP, e se perdeu entre seu processo na Faculdade. Realizamos, durante essa pesquisa, uma consulta especifica sobre este assunto junto à Columbia University, que mantém o arquivo do professor Tannembaum, ainda não totalmente catalogado, e nenhum registro foi encontrado. 
O final desta temporada americana do acervo coincidiu com um período de crise institucional que abateu o Museu. Além da crise financeira desencadeada com a sucessão de empréstimos, o MASP começara a se deparar com falta de espaço na sede da 7 de Abril, ao mesmo tempo em que Chateaubriand começava a se distanciar deste projeto. De fato desde a criação de sua estação televisiva em 1950, a TV Tupi - que funcionava nas dependências do próprio museu, Chateaubriand já vinha aos poucos preterindo um ao outro, além do que, a estação de TV tomava recursos e empenho de seu mecenas.$^{85}$ É em meio a esta crise institucional que surge a proposta de um acordo com a Fundação Armando Álvares Penteado, no qual o acervo e as escolas seriam transferidas para a recém-fundada Fundação e ocupariam a nova sede, que se encontrava no início das obras.

Armando Álvares Penteado, filho mais novo do Conde Álvares Penteado, era conhecido por ser um dos promotores e entusiastas das artes, dono de uma coleção de arte significativa. Falecido em 1947, seu inventário exigia a criação de uma escola de artes junto à preservação da coleção ${ }^{86}$. A viúva Annie Álvares Penteado começa então a negociar com Assis Chateaubriand o acordo com o MASP. Embora a assinatura do acordo, segundo Renata Motta, só tenha ocorrido em dezembro de 1957, esta negociação se encontrava em curso desde, pelo menos, o início do ano anterior. 0 acervo foi então transferido para o edifício da Fundação, assim como todas as instalações das escolas, juntamente com os professores e turmas de alunos de cursos em andamento. Flavio Motta era neste momento o coordenador dos cursos.

0 acordo não teve, no entanto, longa duração. Sabemos que havia algumas desavenças entre as duas instituições, mas não são muito claros os motivos para que o acordo tenha sido desfeito. No entanto, uma das razões seria o fato de Annie Penteado ter vendido grande parte da coleção que imaginava-se pertencer à Fundação, e à medida em que o acordo estabelecia a integração dos acervos e doação para a Fundação, é provável que esta desigualdade entre as coleções tenha pesado negativamente ${ }^{87}$. 0 acervo retornou então à sede da 7 de Abril, porém o curso de Formação de Professores de Desenho permaneceu junto à Fundação ${ }^{88}$, e com ele, também Flavio Motta, que pouco tempo depois desligou-se das atividades do museu para se dedicar plenamente às atividades didáticas.

85 Flavio Motta montou um programa televisivo sobre História da Arte que ele apresentava semanalmente na TV Tupi, chamado Vídeo de Arte. Nele, Flavio falava sobre os assuntos escolhidos e mostrava pranchas com reproduções fotográficas das obras, nos moldes da mostra didática.

86 Lauro Birkholz e Brenno Nogueira, "A FAUUSP, sua criação e funcionamento da Vila Penteado". Sinopses - Edição Especial 'Memória', São Paulo: FAUUSP, 1993, p.9.

87 Renata Motta, op.cit., p.97.

88 O curso deu origem a Faculdade de Artes dessa instituição. 
Em paralelo à sua atuação no MASP, é importante mencionar uma curta iniciativa no campo do ensino da arte da qual participou Flavio Motta: a Escola Livre de Artes Plásticas, que começou a funcionar em abril de 1949. Junto com ele, um grupo de artistas "de renome", todos eles parte do círculo de convívio dos museus recém-criados: Bonadei, Nélson Nóbrega, Volpi, Waldemar da Costa e Waldemar Amarante. Em folheto de divulgação de seu programa, o grupo expõe os objetivos da escola: "orientar vocações artísticas"; e uma vez que a arte é uma "atividade criadora", que não pode ser ensinada no sentido usual da palavra, os cursos pretendem "estabelecer contato entre a vocação e os meios de expressão"89 disponíveis aos alunos.

São oferecidos cursos permanentes de pintura, escultura e desenho. Além deles. alguns cursos voltados à questão das "artes aplicadas" com 3 meses de duração: publicidade, tapeçaria, fotografia, gravura. 0 quadro docente é composto por artistas destacados e certamente reúne algumas das figuras mais significativas do campo artístico brasileiro naquele período: Danilo Di Prete e Waldemar Amarante lecionam no curso de publicidade ${ }^{90}$, Volpi, Bonadei, Waldemar da Costa e Nelson Nóbrega no de desenho e pintura, e Victor Brecheret, Raphael Galvez e Bruno Giorgi no de escultura.

A escola se instala numa casa localizada na Alameda Rio Claro, que foi emprestada aos artistas por Ciccillio Mattarazzo, sendo esta mais uma daquelas evidências de que a rivalidade entre os grupos ligados aos dois museus paulistas era bastante relativa. Apenas uma turma cursou a escola, entre abril e junho de 1949. Aldemir Martins, Mario Gruber, Marcelo Grassmam foram alguns dos alunos.

A medida em que opta por permanecer junto aos cursos na FAAP e abandonar o Museu ao qual estava vinculado há mais de uma década, Flavio Motta acaba por demonstrar uma suspeita que o estudo de sua trajetória já nos levava a afirmar: a de que seu interesse e sua preocupação sempre foi voltada a um projeto educacional. Nesse sentido, é particularmente reveladora uma carta pertencente ao arquivo do MASP, de Flavio Motta para Pietro Maria Bardi, em 02/04/1956, na qual Flavio relata a Bardi acerca do andamento das negociações com a Fundação, e apresenta claramente quais são seus interesses:

"Conversamos e ainda estamos conversando para firmar certos pontos, a saber: a - a Fundação deve ter escritório próprio, organizar-se de maneira impessoal, melhorar

89 Folheto de divulgação da Escola Livre de Artes Plásticas, pertencente ao acervo pessoal de Flavio Motta.

90 O curso de publicidade é o único que consta no folheto com uma breve explicação de seus conteúdos, provavelmente por se tratar de conteúdos novos, desconhecidos do grande público. Assim, consta no folheto a descrição das aulas como sendo de "cartaz, lay-out, ilustração, e artes gráficas". 
a arrecadação e tocar a obra com a máxima rapidez, tendo a frente um administrador enérgico e capaz que facilite ao máximo a execução da obra, acatando as decisões dos técnicos;

b-com a mudança dos cursos e os recebimentos da Prefeitura, os Diários devem deixar limpa a nossa situação financeira de caráter administrativo. Alias, nesse sentido, D. Lina está sendo formidável. Tenho certeza que ela resolve êsses problemas;

c - fazer um plano, bem centrado, com o sr. Assis e a Fundação para realizarmos uma obra cultural, mesmo.

Nesse último tópico o senhor se lembre do meu pedido. Tenho ambições limitadas à escola, ensino e estudo. Acho que já é muito, preparar material humano, através de cursos sistemáticos. Espero concluir, muito em breve, minha "carreira políticoadministrativa". O esforço do dr. Assis e de uma porção de gente, foi grande demais. Precisamos, com o tempo, devolver tudo isso, em termos humanos, em cultura, num trabalho feito com profundidade, com os verdadeiros métodos para o homem moderno, sem retórica e ostentação. Daí o meu desejo de permanecer num setor limitado e aprofundar cada vez mais. Conteúdo, professor, é a minha grande preocupação. Lembre-se também o que já disse ao senhor, antes de partir. Talvez, depois de nove anos de Museu, apesar de todo cuidado, estou cheio daquilo que chamamos "vícios de origem" e, numa obra maior, num programa de desenvolvimento, a gente esteja involuntariamente atrapalhando. Mas, como o senhor sempre foi franco neste sentido, desejo a sua opinião, pois estou convencido que num trabalho maior, devo pensar também em termos de "recuo"; recuo para a qualidade, não recuo para Ciccilios. Isso não! Tamanho esforço financeiro, nesta fase da vida brasileira, exige, pede, aumento de nível cultural, melhoria do espírito criador, ação sobre arquitetos, urbanistas, homens públicos, mudança de mentalidade, trabalho vivo, objetivo que se propague e se infiltre no homem. O contrário, é imoral. O senhor não acha? Gostaria da sua opinião. '91

Através dessa carta, fica claro o que consideramos ser o ponto fundamental na sua trajetória: Flavio Motta sempre perseguiu um projeto educativo, e nesse sentido, aproximavase de Lina e Bardi em sua perspectiva de que esse projeto educacional pudesse contribuir para um projeto nacional. A medida em que o Museu perdeu sua dimensão educativa, Flavio Motta não hesitou em desligar-se dessa instituição e dedicar-se as novas frentes, nas quais pudesse dar continuidade a formação com sentido criador e duradouro que sempre buscou.

91 Carta de Flavio Motta a P.M. Bardi, 2/4/1956. Acervo da Biblioteca e Centro de Documentação do MASP, Flavio Motta / pasta 8. 


\section{4. o ensino como ofício: a história da arte na FAU}

Muito se diz acerca da constituição do curso de Arquitetura e Urbanismo da FAUUSP, de sua origem a partir do curso de engenheiros-arquitetos na Escola Politécnica, e de como esta origem teria marcado um perfil eminentemente técnico dos arquitetos formados na escola, ao contrário dos cursos originários nas escolas de Belas-Artes, que se tornaria uma característica da produção desta escola e do perfil dos arquitetos que emergem desse curso, principalmente na década de 60 em São Paulo.

Entretanto, a medida em que tentamos compreender os acontecimentos que marcam os primeiros anos de curso, a seleção e o processo de ingresso dos professores, a dinâmica do curso nesse período inicial, os conteúdos ministrados, a participação estudantil enfim, a medida em que se pretende compreender a fundo esses primeiros anos da escola, percebemos que as fontes são escassas e muitas vezes truncadas. 0 fato é que, à parte de sua origem da engenharia, pouco se registrou a respeito dos detalhes que compuseram o curso da FAU-USP nos seus anos iniciais. Há poucos trabalhos que tenha estudado, ou mesmo organizado de modo mais sistemático, os programas, as disputas, as reivindicações, ou a importância da escola na cidade e sua articulação com o campo profissional. ${ }^{92}$

Fundada em meio ao movimento renovador e de florescimento de novas instituições que invadem o campo cultural brasileiro após a segunda guerra mundial, ao mesmo tempo, respondia a um conjunto de demandas específicas do campo arquitetônico, reclamando por instituições de ensino autônomas das escolas de Engenharia e de Belas-Artes, que respondessem ao papel cada vez mais significativo que a arquitetura vinha assumindo no cenário cultural.

A figura central no processo de articulação para a criação do curso foi Anhaia Mello, que assumiu o cargo de primeiro diretor da instituição. Responsável por introduzir no curso a matriz do urbanismo, disciplina que havia lecionado na Politécnica, marcando o início do ensino do urbanismo no país de modo desvinculado da engenharia sanitária. Assim, o recém-criado curso de arquitetura era o resultado de uma articulação entre um viés mais técnico originário da Politécnica, e o ensino do urbanismo num molde mais "sistemático e moderno". ${ }^{93}$

E ao mesmo tempo que havia essa dupla referência na técnica e no urbanismo, o curso

92 Entre os poucos trabalhos existentes sobre este tema, podemos citar: Roberto Portugal Albuquerque, Uma escola de arquitetura - FAUUSP: edifícios e ensino. São Paulo, FAU-USP, 2004 (dissertação de mestrado); Nestor Goulart Reis Filho 100 anos de ensino de arquitetura e urbanismo em São Paulo. São Paulo: FAU-USP, 1996.

93 Lauro Birkholz e Brenno Nogueira, "A FAUUSP, sua criação e funcionamento da Vila Penteado". Sinopses, op.cit., p.7. 
também convivia com um modelo pedagógico vindo das Belas-Artes, que já estava presente no curso ministrado na Politécnica, onde apareciam as disciplinas mais tradicionais como "pequenas" e "grandes composições", desenho artístico, arquitetura de interiores, etc. ${ }^{94} \mathrm{~A}$ medida em que seu quadro de professores ia se completando, cada vez mais com arquitetos, tanto aqueles vindos do Rio de Janeiro, alinhados com vertente carioca da arquitetura moderna brasileira, como Hélio Duarte, Zenon Lotufo, Abelardo de Souza e Eduardo Corona, quanto ao grupo local vinculado ao Instituto de Arquitetos do Brasil, como Rino Levi, Vilanova Artigas e Eduardo Kneese de Mello, tem início as discussões que visavam atualizar esse modelo curricular, no sentido de "combater a tradicional dicotomia entre ensino técnico e ensino artístico a partir do enfrentamento, em termos modernos, da realidade material, cultural e política brasileira". ${ }^{95}$

Mesmo tendo sido oficialmente fundada em 1948, a FAU passou os dois primeiros anos sediada no edifício da Escola Politécnica na Avenida Tiradentes, enquanto a casa da Rua Maranhão, doada pelos filhos do Conde Penteado - o mesmo Armando que havia motivado o convênio entre o MASP e a FAAP - era reformada para abrigar a escola. A criação do curso foi aprovada na Assembléia Legislativa no meio do ano de 1948, após intensa pressão dos estudantes que já haviam se inscrito para o exame vestibular. ${ }^{96}$ Por essa razão, o primeiro ano dessa primeira turma foi resumido em apenas um semestre, realizado no edifício da Politécnica, onde também a segunda turma iniciou o curso, pois a Faculdade se mudou para a Rua Maranhão apenas em 1950.

Nesses primeiros anos, houve um acordo para o início do funcionamento do curso, e os professores da Poli lecionavam nas duas escolas. A cada ano se fazia uma seleção para os novos professores que entrariam para aquele ano específico, de modo que o quadro de professores da escola estaria completo apenas em 1952. Em 1951 o arquiteto Oscar Niemeyer foi selecionado para a cadeira de "Grandes Composições", no entanto, as disputas políticas no Conselho Universitário conseguiram anular sua contratação. Em represália, o professor Anhaia Mello, diretor da FAUUSP naquele período, vice-reitor e um dos que mais haviam apoiado a contratação do arquiteto, pede demissão de seu cargo. Os alunos organizam uma greve, que durou quatro meses e teve grande repercussão nos jornais e na própria Universidade. A FAU é então fechada, e assume sua direção um politécnico, Bruno Simões Magro. Até o momento em que Lourival Gomes Machado se torna diretor, em 1962, a Faculdade ficaria sob a diretoria de engenheiros politécnicos.

94 Idem, ibidem. p.9

95 José Lira, Histórico da FAUUSP, Documento elaborado a pedido da Comissão de Coordenação do curso de arquitetura e urbanismo da como subsidio à reformulação do Projeto Político Pedagógico da FAU-USP. São Paulo, 2009 (inédito).

96 Lauro Birkholz e Brenno Nogueira, op.cit., p.10. 


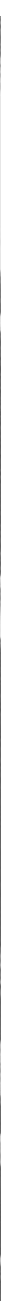

1 e 2. João Xavier, estudante da turma de 1954, registrou diversos momentos de sua turma durante o curso da FAU. Essas fotos são um importante documento de um período da escola escasso em registros, tanto de suas instalações quanto da própria dinâmica das aulas. Nas imagens, vemos os estudantes de sua turma trabalhando nos galpões localizados ao fundo do terreno do edifício Vila Penteado, em 1958.

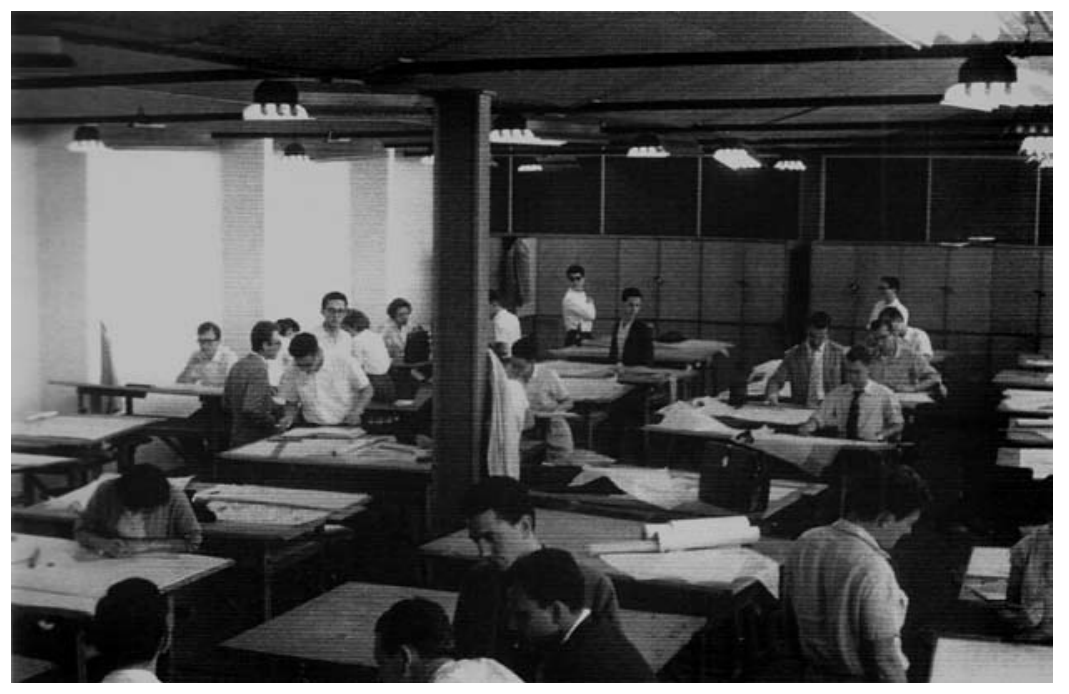


Nesses primeiros anos, os alunos haviam convidado Lourival Gomes Machado para ministrar cursos informais de História da Arte, palestras e discussões, a disciplina no entanto foi incorporada ao currículo regular a partir de $1952^{97}$, para os alunos do quinto-ano. Lourival tornou-se o professor da nova disciplina de História da Arte e Estética. No entanto, Lourival só dá aula como professor regular para duas turmas: em 53, o diretor Cintra do Prado decide suspender todos os contratos dos professores, em apoio a um movimento dos alunos que pedia a renovação do quadro docente.

Aproveitando essa suspensão, numa clara manobra política, o Conselho Universitário afasta aqueles que eram professores efetivos em outra Unidade da USP, alegando que não poderiam dar aula simultaneamente na FAU. Por essa razão, são afastados Lourival, que lecionava Política na FFLC desde 1942, e o próprio Artigas, que também era professor na Politécnica, sendo que Artigas só retorna a FAU em 1955.98 Lourival opta por permanecer na Cadeira de Política da FFLC, desvinculando-se da FAUUSP, e se candidata ao primeiro concurso de Cátedra daquela escola, para o qual é aprovado em 1954. ${ }^{99}$ Nesse mesmo tempo, Flavio Motta é indicado para assumir a vaga de professor deixada por Lourival, para lecionar História da Arte, iniciando o curso em 1954.

Ao que tudo indica, essa não foi uma substituição tranqüila. Segundo o depoimento de alguns ex-alunos das primeiras turmas, houve, num primeiro momento, um certo desconforto com a troca, afinal Lourival já era um professor experiente, crítico de arte reconhecido, atuante na imprensa desde o início da década de 40, tendo sido diretor artístico do MAM, promovido a I Bienal e publicado o livro "Retrato da Arte Moderna no Brasil" anos antes; em resumo, Lourival era uma autoridade no trato da matéria específica. Além disso, Flavio Motta tinha vínculo com o MASP e Assis Chateaubriand, o que certamente era uma exceção no quadro da escola, onde o vínculo com as instituições artísticas do período, era na maior parte dos casos, através do MAM. É possível compreender esse clima a partir da entrevista de Araken Martinho, estudante da FAU entre 1952 e 56, quando comenta o ingresso de Flavio Motta no corpo docente:

“O Flávio Motta quando entrou, foi como se fosse assim uma espécie de proteção política, estava saindo o Lourival Gomes Machado que representava a Faculdade de Filosofia, o que tinha de mais avançado na questão da estética, e entrou o Flávio, filho de ministro e que trabalhava com o Assis Chateaubriand, que sabe como é, naquela época era execrado pela gente - era o 'Roberto Marinho' da época. E o

97 Aracy Amaral, "História da arte na formação do arquiteto", Sinopses, op.cit., p.82-83.

98 Entrevista de Julio Katinsky a João Sodré. Viagens pelo Brasil a partir da FAU-USP, 1948-1962. FAU-USP, Trabalho Programado 3, 2009, p.139.

99 Heloísa Pontes, op. cit. p.196. 
Flávio entrou na escola inclusive com essa cara, mas rapidamente ele desmontou essa imagem inteira, pela lealdade, pela capacidade de trabalho."

De fato, a desconfiança inicial que os estudantes demonstraram em sua chegada, acabou sendo logo dispersa. Todos os depoimentos de ex-alunos evidenciam o apreço que Flavio Motta adquiriu muito rapidamente, e a proximidade que se criou entre ele e os estudantes. Por outro lado, é certo que a inserção no ambiente da FAUUSP foi o canal de aproximação direta entre Flavio Motta e os arquitetos contemporâneos, especialmente Vilanova Artigas e Paulo Mendes da Rocha, que ele conhece na FAU, o primeiro já uma liderança no âmbito acadêmico e profissional, o segundo, formado pelo Mackenzie em 1954 e professor da FAU a partir de 1960.

Já nos primeiros anos de curso, era possível perceber algumas diferenças no conteúdo da disciplina "História da Arte. Estética" quando ministrada por Flavio Motta e Lourival. Diferenças que podem ser apanhadas também na entrevista de Araken Martinho:

"Nós tivemos os primeiros anos de história da arte com o Lourival Gomes Machado, que tinha um projeto muito claro da modernidade e que nos fazia entender de onde vinha aquela coisa toda. Quando o Lourival sai, entra o Flávio Motta. E a enorme capacidade do Flávio Motta era exatamente de entrar na criação. Ele não vai querer mais entrar na discussão 'de onde veio', 'o que aconteceu', 'de onde surgiu'... 'o que foi a semana de 22', 'o que foi o renascimento italiano'... ele era um cara que pegava na massa: como é que a criação se dá"100.

Ao examinarmos comparativamente os programas de curso de Lourival Gomes Machado e o de Flavio Motta para a disciplina em seus anos iniciais tais diferenças ficam evidentes. O curso proposto por Lourival separa "História da Arte" e "Estética", como se fossem duas disciplinas quase que independentes, e de certo modo desconexas. O curso de "História da Arte" é divido em dez módulos que perpassam os períodos artísticos desde a pré-história até o século $X X$, em ordem cronológica, e que aparentemente são bastante fechados em si próprios; ou seja, não há questões que articulem ou extrapolem cada um dos períodos estudados, ao contrário, sua organização parte de uma seqüência cronológica bastante rígida. Além disso, chama a atenção o fato de que a discussão dos séculos XIX e XX se restringe a um módulo para cada um deles, talvez em função do fato de que Lourival naquele momento se especializava nos estudo do Barroco, deixando de lado as questões específicas da modernidade 
e voltando os olhos ao passado. Em suma, a organização do curso demonstra uma sistemática de pesquisa própria a um estudo mais panorâmico.

Se o curso de história tinha essa abordagem mais tradicional das sucessivas escolas, ao mesmo tempo, a parte correspondente ao curso de Estética nos parece muito mais próxima do campo da crítica. Nele, propõe-se discutir as questões relativas às aproximações ou diferenças entre julgamento estético e juízo crítico, a análise dos "fatores sociais" da criação da obra de arte, e por fim uma discussão que aproxima a crítica, a história da arte e a estética ${ }^{101}$. Ainda assim, trata-se de um curso de Estética independente dos conteúdos anteriores, centrado nas discussões próprias ao estudo teórico da disciplina.

É possível que os dois anos apenas que Lourival permanece na escola não tenham sido tempo suficiente para estruturar um curso articulado com as preocupações mais próximas dos arquitetos naquele período, e ao mesmo tempo, não há registros de que tenha lecionado História da Arte anteriormente a esta experiência na FAU. Flavio Motta, ainda que fosse um jovem professor, já tinha naquele momento alguma experiência no assunto, seja através das experiências como monitor no MASP, função na qual uma de suas principais atribuições era apresentar o panorama da história da arte para os visitantes a partir da exposição didática, seja como professor efetivo da disciplina no curso do IAC entre 1951 e 1953. O fato é que o curso elaborado por Flavio Motta nos parece muito mais próximo às discussões contemporâneas e aos interesses dos arquitetos e da nova escola, e é possível pensar que seja através dessa capacidade de lidar com as articulações entre os campos que o tenha tornado tão próximo dos arquitetos.

Em seus primeiros dois anos na escola, 1954 e 1955, Flavio Motta, ao que tudo indica, ministrou o mesmo curso organizado por Lourival. ${ }^{102} \mathrm{O}$ primeiro programa proposto por Flavio é o de 1956, que traz grandes mudanças em relação ao curso anterior. Ainda que se mantenha uma característica de um curso panorâmico, que atravessa todas as épocas desde a pré-história até a arte contemporânea, na proposta de Flavio Motta os períodos artísticos, ainda que apresentados numa seqüência cronológica, são agrupados através de algumas questões que compartilham e que os aproximam, de modo que a partir de cada conjunto de temas seja possível propor algumas discussões contemporâneas. Um exemplo é o primeiro módulo do curso, intitulado "O homem e as primeiras manifestações artísticas": nele, além dos estudos de cada uma das "fases" e características da arte pré-histórica, consta no programa uma discussão dos temas "O homem e a cultura; A linguagem como veículo de

101 FAUUSP, Programa do Curso para 1953, "História da arte e estética". 1020 programa de todo o curso da FAUUSP para 54 e 55 foi idêntico ao de 53. 

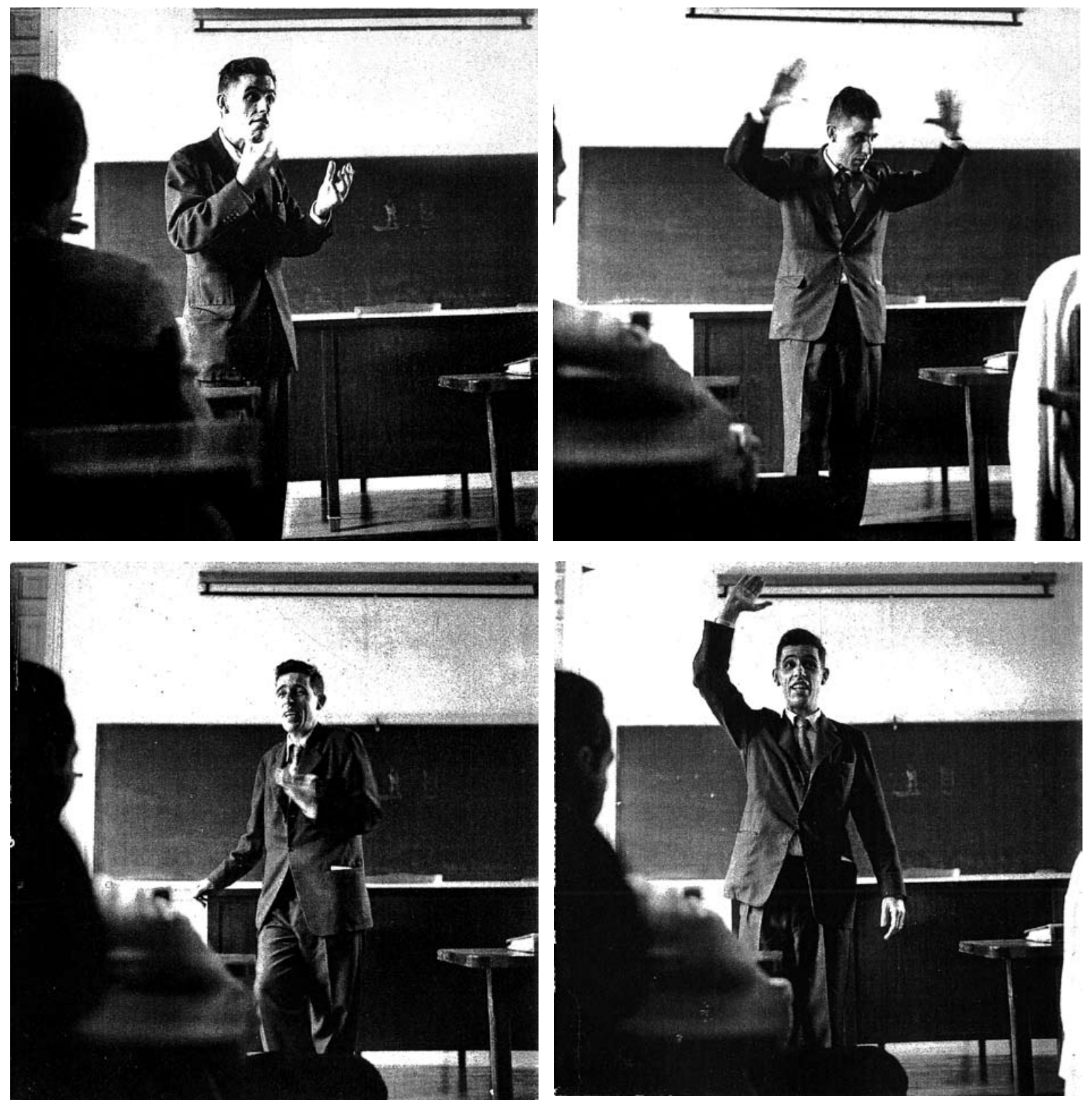


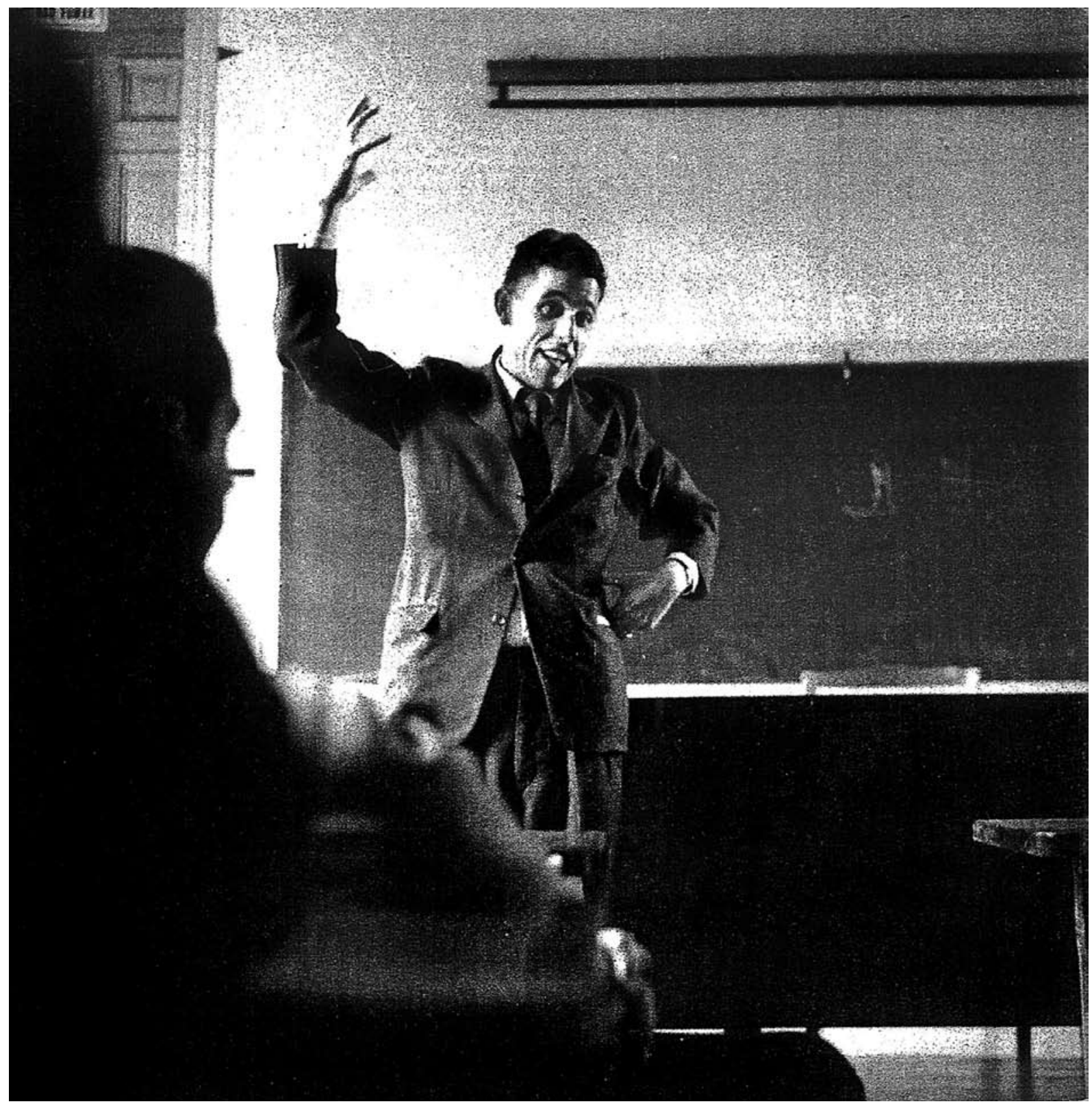

1 a 5. Flavio Motta em sala de aula, no curso de História da Arte na FAU, em 1958.

Fotos de João Xavier, que era seu aluno nessa turma. 
cultura; Arte e expressão religiosa, social, econômica e individual; Arte e cultura", e ainda, uma aula dedicada à discussão da "arte primitiva e sua influência na arte contemporânea". ${ }^{103}$

E a medida em que cada período específico pode ser associado às diferentes questões, os temas referentes a Estética vêm juntos aos estudos de História da Arte. Assim, em nenhum dos cursos propostos por Flavio Motta desde 56 há a separação entre História da Arte e Estética como assuntos independentes, a estética é estudada aqui a partir das obras de arte de cada período. Esta questão nos parece que será fundamental alguns anos depois, quando se articula a criação do Departamento de História da Arquitetura e define-se a existência de uma categoria específica de estudos dentro da Faculdade, que é a Estética do Projeto. Esta idéia nos remete diretamente a esta primeira abordagem da estética, neste curso de 1956, que a aproxima da experiência particular de cada obra.

Outra novidade que aparece no programa de História da Arte a partir de 1956 é o início de um estudo sob uma perspectiva mais historiográfica: junto com o estudo das características e das obras das escolas específicas de cada período, aparece em algumas delas o estudo dos "teóricos" daquele assunto, consta no programa, por exemplo, um estudo específico dos "teóricos do barroco", "teóricos do renascimento", etc. Nos anos seguintes, essa nova perspectiva irá se acentuar, e sem dúvida, representa toda uma corrente de pesquisa que se tornará fundamental também na medida em que se constitui o Departamento de História da faculdade.

Por último, a maior novidade que aparece neste programa é que quase metade do curso é voltado ao estudo da arquitetura do final do século XIX e do século XX. Naquele momento, o curso da FAU não possuía nenhuma cadeira dedicada ao estudo da arquitetura a partir de um ponto de vista da estética, nem que tivesse tanta ênfase na produção contemporânea internacional. A única disciplina teórica que então abordava os sucessivos períodos arquitetônicos era "Arquitetura Analítica", que se tratava muito mais de um "estudo dos estilos" arquitetônicos do que de fato um estudo da história da arquitetura voltado à reflexão da produção contemporânea. Uma evidência desse caráter era que o curso de Arquitetura Analítica, nesses primeiros anos, tinha como trabalho prático o "desenho de fragmentos de arquitetura e ornatos característicos dos estilos". ${ }^{104}$

O programa de História da Arte de 1956 tinha como módulos específicos de estudo os trabalhos de Perret, Loos, Tony Garnier, Theo Van Doesburg, Oud, Frank Lloyd Wright, Gropius, Mies Van der Rohe, Le Corbusier, Alvar Aalto, e ainda os grupos de Sullivan e a Escola de Chicago, "De Stijl", a Bauhaus, etc. Esta escolha dos temas recentes, do estudo 
das vanguardas e da arquitetura moderna, e a tentativa pioneira de trazê-la para o curso da FAU demonstra uma afinação peculiar aos temas e preocupações dos arquitetos, muito provavelmente adquirida no Museu através das exposições de arquitetura, do curso do IAC e do convívio com Lina e Bardi. E ainda, a opção por inserir diretamente a arquitetura no curso de História da Arte e Estética, repercute não somente uma forma de transgredir os conteúdos tradicionais, mas é coerente com um certo entendimento da disciplina, a partir o qual a perspectiva histórica e estética do estudo da arte era mobilizada para compreender o momento contemporâneo das manifestações arquitetônicas e o lugar da arquitetura brasileira frente ao quadro internacional.

Apesar disso, curiosamente, essa ênfase na arquitetura contemporânea sai do programa do curso no ano seguinte. Depois de 56, nenhum outro programa proposto por Flavio Motta no curso de História da Arte retoma a discussão dos temas da arquitetura contemporânea internacional com a mesma ênfase que havia neste programa de 56 . Não se sabe exatamente por que razão um programa tão instigante aos arquitetos tenha sido abandonado depois dessa experiência inicial, afinal o exame dos programas para o curso da FAUUSP nos anos imediatamente posteriores, revela que nenhuma outra disciplina se propôs a abranger esta discussão. É possível que os debates de reformulação dos currículos que se desenrolaram naqueles anos pretendessem suprir a demanda por uma discussão da produção de arquitetura moderna internacional em outros fóruns, ou então tornar este debate mais especializado. 0 fato é que os temas mais específicos da arquitetura contemporânea não aparecem mais após esta primeira formulação do curso de Flavio Motta.

Ao mesmo tempo em que desenvolve este curso, Flavio Motta organizou um pequeno grupo de estudos que naquele ano se dedicou à leitura da obra de Gideon. 0 grupo também era composto por Artigas, Mario Wagner e os alunos Araken Martinho, Julio Katinsky, Abrahão Sanovicz e Heitor Ferreira de Souza, e se reunia todas as quintas-feiras durante a noite no edifício da FAU para ler e discutir "Espaço, Tempo e Arquitetura", que havia sido lançado em 1941: "Foi uma leitura que abriu completamente a perspectiva da compreensão do papel da arquitetura naqueles anos, [...] e o Flávio Motta era aquele poeta de sempre, jogando as imagens em cima da gente, fazendo com que a gente compreendesse o Giedion com coisas brasileiras. "105

Ainda segundo o depoimento de Araken, este grupo de leitura do Gideon teve um desdobramento prático naquele mesmo ano, que se tornou a primeira experiência de Flavio Motta numa equipe de projeto: Vilanova Artigas convidou os companheiros do grupo de leitura a montarem uma equipe para participar do concurso de Brasília, juntamente com alguns

105 Entrevista de Arakén Martinho a João Sodré. Viagens pelo Brasil a partir da FAU-USP, 1948-1962. FAU-USP, Trabalho Programado 3, 2009, p.144. 
outros colaboradores. Segundo ele, uma série de discussões que se iniciaram no grupo de estudos, foram retomadas nos debates de projeto do concurso, e o projeto do grupo acabou tendo diretrizes muito particulares a partir dessa presença multidisciplinar.

Além de Artigas, Flavio Motta, e Mario Wagner Vieira da Cunha, a equipe tinha a presença de Carlos Cascaldi, Paulo de Camargo e Almeida e dos estudantes Júlio Katinsky, Ubirajara Gilioli e Araken Marinho, que não concluiu o trabalho ${ }^{106}$, que acabou sendo elaborado a partir de um amplo estudo da região e das condições sócio-econômicas locais. A equipe apresentou um dos mais extensos relatórios do concurso e 19 pranchas. Flavio Motta redigiu o memorial descritivo. A equipe desenvolveu o projeto para o concurso no edifício em obras da FAAP, que já vinha sendo preparado para receber as escolas e o acervo do Museu. ${ }^{107}$

O plano tinha como idéia central o desenvolvimento da cidade de Brasília como distribuidora de população e geradora de recursos no interior do país. Assim, planejava-se o desenvolvimento da indústria local apenas limitada às necessidades da cidade, já que as cidades da redondeza teriam seus próprios pólos. Desenvolveram um extenso e completo plano regional e de desenvolvimento da cidade a longo prazo, sendo que o relatório apresenta as projeções de crescimento populacional e projetos para saúde, educação, etc.

1. Projeto da equipe de Vilanova Artigas para o Plano Piloto de Brasília

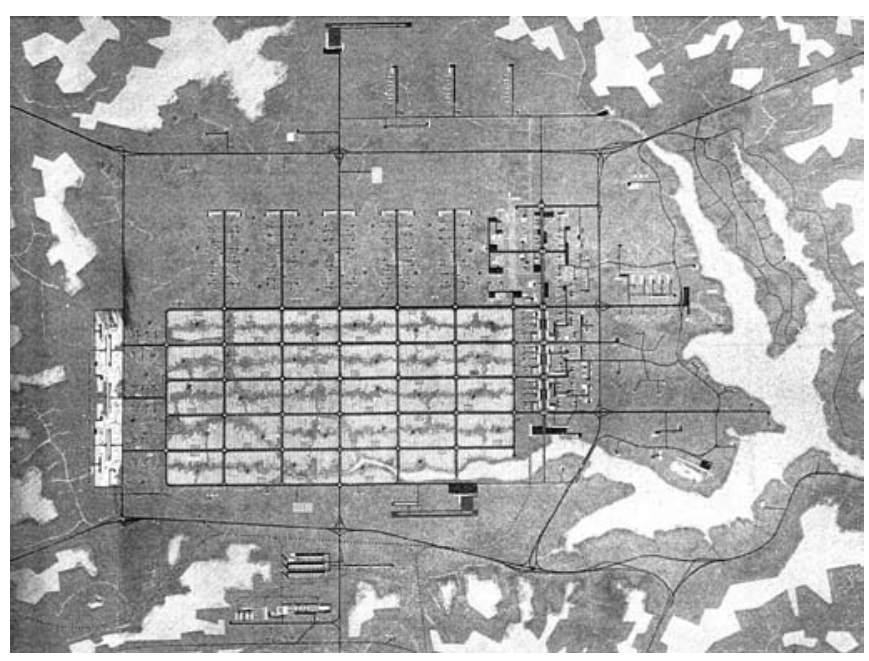

106 Segundo o depoimento de Araken, ele abandonou a etapa final do concurso após uma discussão com Artigas, por esta razão, seu nome não aparece no projeto.

107 Segundo depoimento de Flavio Motta a autora. 
O desenho é baseado em uma malha retilínea e ocupa grande extensão - um dos principais pontos criticados pela comissão julgadora. 0 centro governamental está adjacente ao centro comercial. A idéia era justamente aproximar as duas funções, e transformar este espaço no grande espaço de convívio da população, o centro de cultura e lazer. As habitações estão nas zonas residenciais que são de três tipos: a maior delas (Z1) concentra unidades de vizinhança em residências isoladas e individuais, em lotes, com seu núcleo de comércio e serviços locais e equipamentos principais. A maior parte da população concentra-se nesta área. A Z2 possui unidades de vizinhança em blocos de apartamentos de até 10 andares. A última, Z3, é contígua à zona industrial e destinada a habitação de baixa renda, para operários, população construtora, etc.

0 projeto manifestava em sua apresentação uma preocupação em relação à população construtora. Segundo Milton Braga, que em sua dissertação de mestrado descreve todos os projetos premiados no concurso, não há nenhum outro projeto que apresente tão extensamente a questão ${ }^{108}$. A equipe prevê o destino dessa população após o término das obras, apresentando uma proposta que prevê a absorção de cerca de 30 mil trabalhadores pela economia da nova capital, assim, iniciar-se-ia a construção da cidade pela zona habitacional 3, que inicialmente seria a área de alojamento da mão-de-obra, e quando a construção da cidade estivesse completa, seria incorporada à malha da cidade. 0 depoimento de Arakén Martinho explica melhor as origens dessa idéia na contribuição multidisciplinar:

"O Artigas montou esse projeto todo baseado nas sete linhas do Le Corbusier. Ele não admitia muito que você entrasse no meio daquilo, ele tinha uma consciência claRa. Como faziam parte do grupo também o Flavio Motta e o Mario Wagner Vieira da Cunha, nós fizemos uma discussão que para mim era o mais importante: a partir do Mario Wagner e do Flavio Motta, havia uma discussão que nenhum outro projeto tinha, e que eu não sei se foi muito bem explicitada no projeto... O Mário Wagner tinha uma consistência, em termos de conhecimento... ele disse 'veja bem, o que me parece é que esse presidente vai querer fazer essa capital mesmo, e para fazer essa capital ele vai ter dois anos, e para fazer em dois anos, ele vai ter que ter uma busca de mão de obra, o que vai provocar um movimento enorme de gente do Nordeste e o Norte para ir construir Brasília, e isso vai ser na verdade uma migração, e não existe nenhum caso brasileiro de migração com retorno, toda vez que houve migração no país, o migrante vai e fica. O nordestino vai pra São Paulo e fica em São FAUUSP, 1999. 
Paulo, ele não vai lá para ganhar dinheiro e volta. Ao contrário, ele traz a família. Vai acontecer a mesma coisa'. Se vai acontecer a mesma coisa, se as pessoas iam ficar no lugar, o que se propunha? A partir do projeto do Artigas, que se encaixava nos lagos, ele propõe um cinturão de produção agrícola, formando chácaras que deveriam ser doadas para esses trabalhadores, cuja base é a agricultura, e essas chácaras produziriam alimento para Brasília. Possivelmente, se essa solução tivesse sido adotada, você não teria cidades satélites. Você teria um outro contexto naquela região, e isso nunca foi discutido".

Após a experiência no concurso de Brasília a partir de 57, no mesmo ano em que tem início o curso da FAAP, o curso de História da Arte de Flavio Motta se desenvolve ao longo dos anos seguintes por dois caminhos simultâneos: o primeiro foi o de associar o currículo mais panorâmico com pesquisas individuais mais aprofundadas, e o segundo o de se voltar cada vez mais à arte brasileira e aos estudos do modernismo no Brasil.

Por um lado, têm-se a impressão de que logo cedo o professor tenha percebido que ao mesmo tempo em que era necessária a apresentação de um panorama mais geral da História da Arte, era preciso incentivar a pesquisa aprofundada e consistente, característica do processo de formação universitária. Independentemente de qual fosse a questão a ser estudada, a intenção era permitir que os alunos fossem capacitados a mergulhar em um certo problema, mais como um método de ensino do que pelo interesse em alguma questão em particular. Essa idéia é apresentada na introdução de diversos dos programas daí para frente: "Considerando que os alunos estudam a matéria pela primeira vez, torna-se indispensável apresentar uma visão panorâmica dos principais capítulos da História da Arte, desde a préhistória até o século XX. A par desse estudo em extensão, a classe será subdividida em grupos, orientado cada um à pesquisa aprofundada de temas limitados e previamente escolhidos". ${ }^{109}$

Nesse sentido, o curso de 1957 propõe um seminário de estudos nos mesmos moldes do grupo do Gideon, "com o objetivo de fortalecer a preparação metodológica dos alunos", sugerindo que a leitura daquele ano seja o livro de Lewis Mumford; já o de 1962, além do grupo de leitura, inclui nesta perspectiva de estudo mais aprofundado a realização de "exposições circulantes", organizadas pelos alunos da disciplina e o desenvolvimento de pesquisas individuais.

Ao mesmo tempo em que se estimula a pesquisa individual, o que se pode observar através dos programas é que, cada vez mais, os interesses da disciplina se voltam para o estudo da arte moderna brasileira, do modernismo no Brasil e da cultura popular. Essa temática 
específica aparece pela primeira vez no programa do curso de 1961, no qual também se abandona o estudo dos períodos relativos à Antiguidade e à Idade Média - a disciplina a partir deste ano começa a ter como recorte o estudo da História da Arte entre fins do século XVIII e o século XX.

O primeiro módulo desse ano de 61 tem como primeiro tema "O movimento moderno no Brasil e a necessidade de um reexame histórico-crítico", além disso, após o módulo que trata do século XX, é incluído no programa um item específico de estudo do "Movimento Modernista no Brasil". A estes temas, no programa de 1962 aparecem também o estudo da "arte popular", da "arte entre as crianças e os alienados", "arte negra" etc., de certo modo retomando temas que estavam em voga durante sua experiência no Museu de Arte de São Paulo. A partir de 66 sugerem-se temas específicos para a elaboração de monografias, dando início ao que viria a se transformar, no ano seguinte, em dois projetos de pesquisa desenvolvidos junto ao IEB, à FAPESP e à Biblioteca da FAU, intitulados "O movimento modernista no Brasil (Artes Plásticas)" e "Artesanato Popular", que partia de uma "coleta de dados preliminares para a documentação sobre a vida e obra dos principais artistas brasileiros".

Em 62, o curso também ganha importantes contribuições com o ingresso de dois professores assistentes, Julio Katinsky e Sérgio Ferro, ex-alunos de Flavio Motta que se graduaram em 57 e 62, respectivamente. A presença dos assistentes contribuiu para a incorporação definitiva dos temas da arte brasileira no programa do curso, e de um esforço de consolidação e sistematização dos estudos de História da Arte no Brasil a partir desse período, assim como essa abertura do olhar para a cultura popular. Julio Katinsky, por exemplo, que havia sido do Centro de Estudos Folclóricos do GFAU ${ }^{110}$, foi quem sugeriu a incorporação do estudo do artesanato popular ao conjunto de temas a serem pesquisados na disciplina, propondo como temas de pesquisa, por exemplo, a produção dos artesãos do Vale do Paraíba e dos artesãos japoneses ${ }^{111}$.

E ao mesmo tempo em que incorporava a pesquisa individual à dinâmica do curso, Flavio Motta mantinha um método próprio de discutir história da arte em sala de aula, escapando das apresentações a partir de seqüências cronológicas. Segundo Sergio Ferro,

"o método do Flavio Motta não era o de um historiador comum. Em vez de uma exposição linear, ele organizava seus cursos por temas: Iuz, cor, forma, etc. Ele os mostrava com obras de pintores de vários períodos. Na mesma aula falava de

110 A respeito do centro de estudos folclóricos e também dos anos iniciais da FAUUSP, ver a dissertação de João Sodré, Arquitetura e viagens de formação pelo Brasil, 1948-1962. São Paulo: FAUUSP, 2010. 111 Entrevista de Julio Katinsky a autora, em 21/08/2009. 
Velásquez, Van Gogh ou Picasso. [...] O Flavio Motta era leitor assíduo e nos indicava textos e tratados a consultar. Mas, ao mesmo tempo, nos punha em contato direto com as obras de arte. lamos ao MASP desenhar, decompor, re-estruturar algum quadro. Sua máxima era semelhante à de Mao-Tse Tung: para conhecer uma maçã, há que comê-la nalgum momento. O curso do Flávio Motta foi essencial para mim." 112

Ao mesmo tempo em que se implementavam as mudanças nos programas dos cursos, as pressões pela revisão pedagógica que já vinham ocorrendo desde as agitações de 1951 tiveram como desdobramento a formação de uma comissão encarregada de elaborar uma nova proposta curricular que aproximasse a escola das novas questões nacionais. Encabeçada por Vilanova Artigas, Abelardo de Souza, Rino Levi e Helio Duarte ${ }^{113}$, representava uma tentativa de aproximar a atividade do arquiteto ao processo de modernização do país, seja através da contribuição direta nas novas possibilidades de desenvolvimento técnico e territorial, ou do desenvolvimento de uma perspectiva teórico-crítica que colocaria a escola na vanguarda do ensino de arquitetura no plano nacional.

A Reforma de 1962 é aprovada justamente quando Lourival Gomes Machado assume a diretoria da FAU. A nova estrutura de ensino organizava a escola em 4 departamentos: Composição, Histórico-Crítico, Ciências Aplicadas e das Técnicas, sendo que as disciplinas de Composição foram agrupadas em quatro linhas didáticas - comunicação visual ou expressão gráfica, desenho industrial, arquitetura de edifícios e planejamento. ${ }^{114} \mathrm{Com}$ a nova organização, a escola deixava pra trás a dupla tradição das escolas de arquitetura do país - entre as Belas-Artes e a Politécnica - e articulava a noção do fazer, do projetar como eixo em torno do qual se organizariam os diversos conhecimentos ${ }^{115}$. Além disso, a introdução do Desenho Industrial na esfera de assuntos que a escola passaria tratar, trazendo os objetos para a escala de trabalho do arquiteto, inseria a articulação entre o projeto e a produção industrial como um dos temas centrais da atividade da arquitetura. Nesse sentido, é possível pensar que a experiência pioneira do IAC transformava-se, dez anos depois, numa relação muito mais próxima da experiência da Bauhaus e da escola de Ulm, e remetia ao campo da arquitetura preocupações mais gerais do projeto de industrialização do país ${ }^{116}$.

A reestruturação curricular da FAU não era, no entanto, um episódio isolado no âmbito

112 Entrevista de Sérgio Ferro a Felipe Contier, em 31/01/2008, p.1-3. Inédito.

113 Editoria Caramelo, "Fórum: o percurso do ensino na FAU". Caramelo, no 6, 1993. p.10.

114 José Lira, op.cit.

115 Luiz Carlos Daher. "O espaço arquitetônico brasileiro dos últimos 20 anos e a formação profissional do arquiteto", Sinopses, op.cit.,p.156.

116 A esse respeito, ver Ana Luiza Nobre, Fios cortantes: projeto e produto, arquitetura e design no Rio de Janeiro (19501970), e Juliano Aparecido Pereira, A ação cultura de Lina Bo Bardi na Bahia e no Nordeste (1958-1964). 
universitário. Naquele momento, diversas unidades discutiam seus currículos, a Universidade passava por uma tentativa de modernização conduzida pela reitoria de Ulhôa Cintra, que tinha o apoio dos setores progressistas de diversas unidades. Discutia-se o apoio à pesquisa, a docência em tempo integral, uma maior integração das unidades, e mais do que isso, uma proposta de Universidade que se aproximasse dos grandes problemas nacionais. 0 momento era agitado, com os estudantes engajados na crítica ao sistema de Cátedras e reivindicando maior participação nas estruturas de poder. Nesse ano, 1962, realiza-se uma greve em favor da participação estudantil nos órgãos colegiados, que reclamava a proporção de $1 / 3$ de seus membros. O Conselho Universitário, nesse momento, se polarizava entre um grupo conservador e defensor do sistema de Cátedras, e aqueles adeptos da modernização, que se tratava de um grupo muito heterogêneo para que pudesse ser designado "de esquerda". ${ }^{117}$

Neste quadro de divergências, foi eleito para a reitoria da USP em 1963 o professor Gama e Silva, que a princípio havia assumido o compromisso de dar andamento na renovação universitária, mas no ano seguinte, com o golpe militar, dá início a "uma intensa atuação política a nível federal e estadual no sentido de ser incorporado ao novo governo" 118 , posto que efetivamente conquistou, como demonstra sua assinatura junto a do presidente Costa e Silva nos decretos de afastamento dos professores em 69. Nesse sentido, a repressão policial que atacou a Universidade imediatamente após ao golpe militar não encontrou nenhuma resistência por parte da reitoria, ao contrário, se fez com a sua conivência.

O currículo proposto na Reforma de 62 seria posto em prática apenas de modo parcial neste ano em que foi aprovado, e seu processo de implementação previa que fosse gradualmente implantado até 1964 . No entanto, os acontecimentos do período interromperam o processo completo de instauração do novo currículo. 0 novo diretor que assumiu a escola após o Golpe pretendia restaurar o ensino aos moldes politécnicos, acirrando o embate entre a direção da escola e os alunos, que tentavam manter as conquistas da reforma curricular. Em 64, um relatório elaborado internamente à Universidade, por uma comissão nomeada pelo reitor para investigar as "infiltrações de idéias marxistas" nas unidades, denuncia 52 pessoas. Sob essa desculpa, tratava-se na verdade, de "realizar um expurgo pautado sobre critérios pessoais de 'pureza revolucionária' e feito sob medida para permitir aos setores conservadores o monopólio de poder na USP". ${ }^{119}$ Com esse propósito, a lista de afastados conseguia atingir todos os grupos mais inovadores e aqueles que apoiavam a orientação da reitoria de Ulhôa

117 Segundo relatório em O controle ideológico na USP, 1964-1978. Associação dos Docentes da USP, São Paulo: ADUSP, 2004, p.11.

118 Idem, ibidem, p.12.

119 Idem, ibidem, p.17. 
Cintra, e não necessariamente englobava todos os professores que poderiam ser considerados "de esquerda", e mesmo incluía alguns que nunca foram, de modo a conseguir neutralizar o grupo mais progressista e interromper alguns dos processos de renovação nas unidades. No caso da FAUUSP, foram indicados pelo relatório os professores Vilanova Artigas, Abelardo de Souza e o estudante Silvio Sawaya. Artigas acabou sendo preso, e embora tenha ficado apenas 12 dias na cadeia, passou um ano no exílio no Uruguai e retornou à FAUUSP apenas em $67^{120}$, pois os inquéritos que absolveram os professores acusados só foram encerrados em 1966.

Este período coincide também com um questionamento no interior da escola, da capacidade da indústria nacional como meio de solucionar os problemas nacionais e se aproximar das camadas populares, ao mesmo tempo em que a FAU se tornava um dos pólos de experimentação artística e cultural do país, definindo cada vez mais seu perfil composto tanto através da experimentação quanto do acirramento crítico: "de um lado, enquanto única escola de arte até então existente na Universidade de São Paulo, animava experiências pop, neo-concretistas, tropicalistas, neo e pós-vanguardistas; de outro, levava ao paroxismo o questionamento dos desígnios da prancheta em nome do engajamento na crítica e na política". ${ }^{21}$

Com o final dos inquéritos, delineou-se a retomada do espírito universitário, ao mesmo tempo em que se acirra a radicalização do movimento estudantil, coincidindo com um momento em que a necessidade de reformar a universidade brasileira é assunto cada vez mais latente em âmbito nacional ${ }^{122}$. É evidente que esta agitação se repercute no ambiente da FAU, que viveria no final desta década seu período mais conturbado. Em relação específica à modernização de sua estrutura curricular, em 1968, com a eleição de Ariosto Mila para a diretoria da FAU, um novo Fórum foi convocado, realizado entre maio e julho, na tentativa de rever e atualizar as diretrizes da Reforma de 62. As propostas do Fórum chegaram a ser aprovadas pela reitoria, no entanto, a cassação do reitor com o Al-5 fez com que todas as suas decisões fossem revogadas, inclusive a reforma curricular da FAU. ${ }^{123}$

Em meio aos estremecimentos do período, Flavio Motta defende sua tese de Cátedra apenas em 1968, exatos 11 anos depois do trabalho ter sido concluído. A Faculdade havia solicitado que Flavio Motta prestasse o concurso de Cátedra em 1957, às pressas, e ele optou por desenvolver uma pesquisa que já havia iniciado alguns anos antes acerca da presença do Art-Noveau no Brasil. O início dessa pesquisa remetia aos tempos da revista Habitat, para a qual Flavio Motta havia escrito o artigo "São Paulo e o Art-Noveau" publicado em 1953.

120 Editoria Caramelo, op.cit, p.11-12.

121 José Lira, op.cit.

122 ADUSP, op.cit., p.26.

123 Editoria Caramelo, op.cit., p.13. 
Para não nos determos muito no conteúdo do trabalho específico, a dissertação que Flavio apresenta para o concurso de cátedra, "Contribuição ao estudo do Art-Noveau no Brasil", parte de uma breve contextualização do movimento na Europa, apresentando o modo como o movimento apareceu em cada país, para em seguida analisá-lo no contexto nacional. Além do mérito de representar um estudo pioneiro no assunto, o trabalho desenvolve uma leitura muito peculiar do movimento Art-Noveau, que é a idéia de que contribuiu para o desenvolvimento do movimento moderno do Brasil. Esta idéia é desenvolvida por Flavio Motta a partir do lugar do Art-Noveau como um antecedente do modernismo, no qual prevalecia um caráter de transição, que dá ênfase às manifestações inventivas individuais, num momento em que o Brasil tentava "ganhar sua maioridade intelectual". Irradiado a partir do Liceu de Artes e Ofícios em São Paulo, mantinha sua característica de "arte aplicada", no entanto, era expressão das conquistas técnicas e do progresso.

O longo intervalo entre a conclusão do trabalho e sua defesa teve como principal razão as disputas internas na escola, mas também as dificuldades e percalços do período. A banca indicada para examinar o trabalho era composta pelos seguintes professores: Ariosto Mila, então diretor da FAUUSP, Eurípedes Simões de Paula, diretor da FFLC, Mario Barata, Rodrigo de Mello Franco e Nestor Goulart Reis Filho, que havia sido aluno de Flavio na FAU ${ }^{124}$ e naquele momento era Chefe do Departamento de História da Arquitetura e Estética do Projeto.

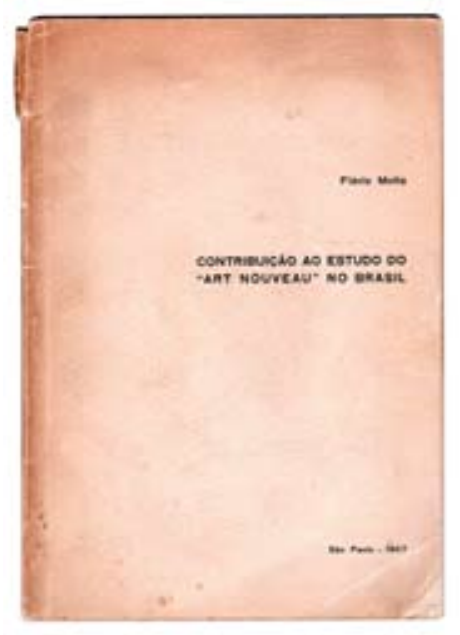

1. Tese de Cádedra, Contribuição ao Estudo do Art-Noveau / capa

124 Nestor graduou-se na FAUUSP em 1955 e logo em seguida, cursou Ciências Sociais na FFLC, graduando-se em 1962. Realizou seu concurso para Cátedra na FAU em 1967. 
Os anos que se seguem à defesa da tese de Cátedra coincidem com o período mais difícil da escola, com a mudança para o novo edifício da Cidade Universitária, a cassação de professores como Vilanova Artigas, Paulo Mendes da Rocha e Jon Maitrejean, as prisões e o endurecimento do regime militar, que fazem com que a escola perca muito de sua agitação cultural e a atualidade de suas discussões. Os que ficam tentam manter a produção crítica e culturalmente relevante, e utilizar da melhor maneira possível a estrutura disponível. São desse período os pequenos livrinhos de desenho editados por Flavio Motta na própria gráfica da faculdade, num sentido de "seguir em frente" e tentar retomar um clima mais criativo e experimental'125, e ainda a coletânea "Textos Informes", um conjunto de textos sobre arte e arquitetura, quase todos escritos entre 1970 e 1973, que é certamente o trabalho escrito mais conhecido de Flavio Motta.
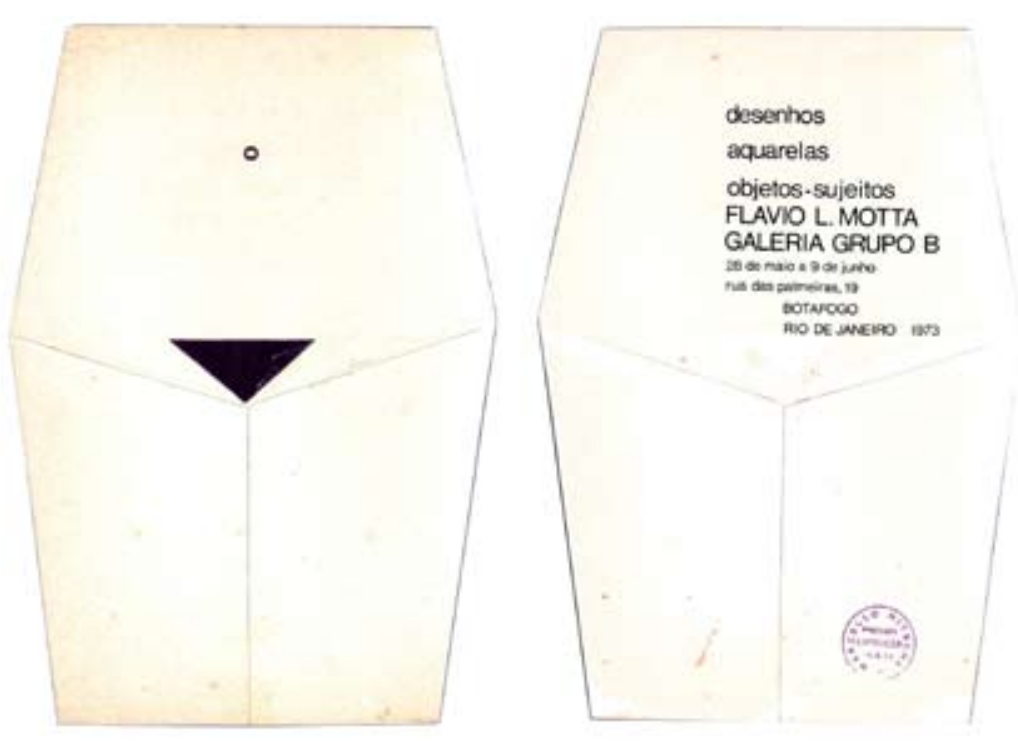

125 Alguns desses livrinhos, como Love Story, Tudo Novo e Nus em série, estão disponíveis na biblioteca da FAUUSP. Love Story foi confeccionado também em uma "edição especial", impressa em diferentes pedaços de papel da gráfica da FAU que seriam jogados fora, que foi batizada de "Edição de Lixo". 


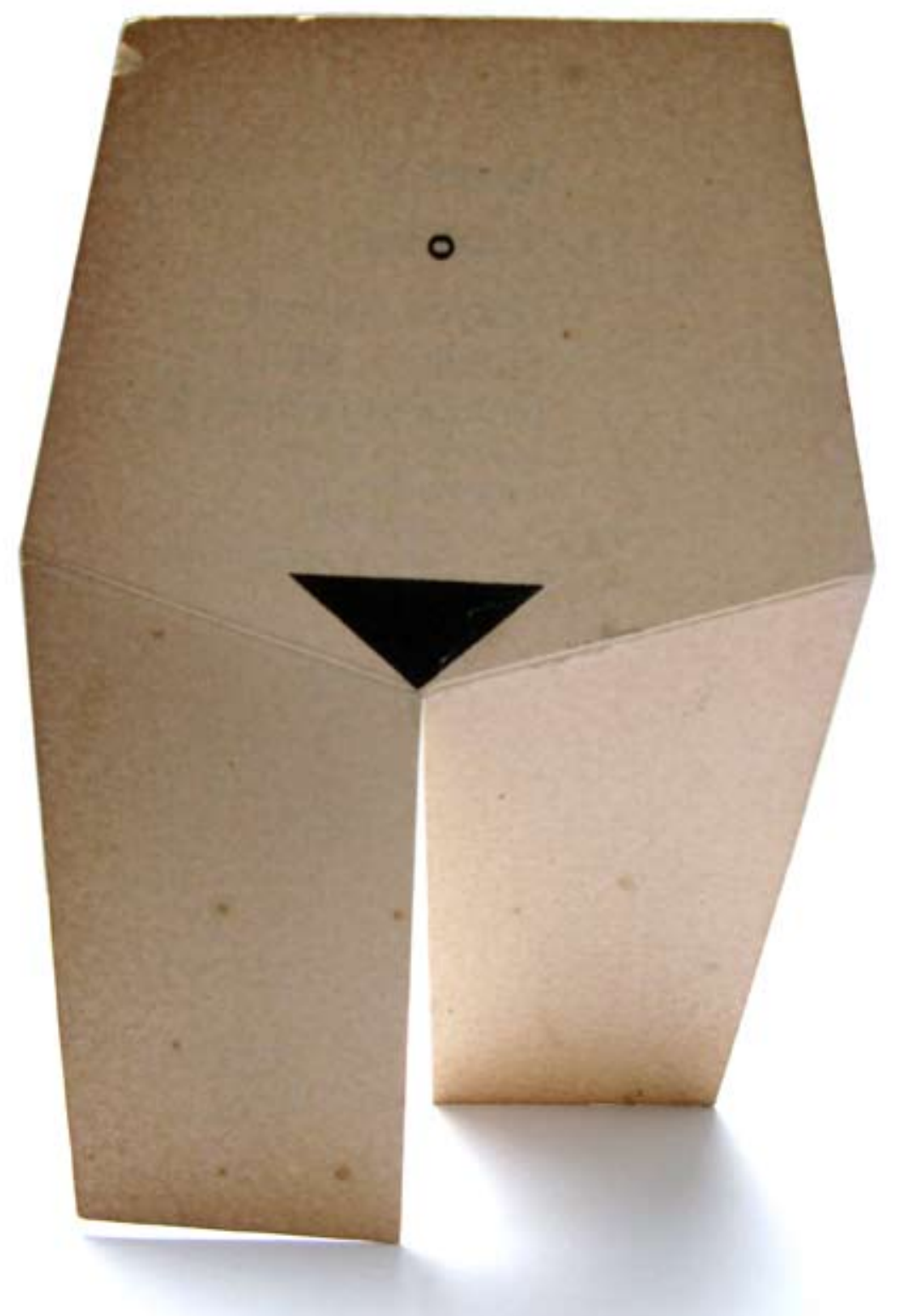

1 e 2. convite para exposição de desenhos de Flavio Motta na Galeria carioca GrupoB, 1974 - frente e verso.

3. convite "em pé". 
Se a situação na escola era difícil, por outro lado, os anos finais da década de 60 e início de 70 são de intensa produção artística. Nesse período Flavio Motta realizou diversas exposições, como a individual na galeria carioca GrupoB em 1973, e colaborações com outros artistas e intervenções no espaço urbano. Entre elas, um happening coletivo intitulado "Bandeiras na Praça", que organizou junto com Nelson Leirner, e do qual também participaram Helio Oiticica, Carmela Gross, Rubens Gerchman, Carlos Vergara, entre outros. Realizado em 1967 em São Paulo, e no ano seguinte no Rio de Janeiro, cada artista carregava sua bandeira, numa demonstração do "clima gregário e festivo das manifestações daqueles anos"126. Outro exemplo é a intervenção "Superfícies Habitáveis" realizada em dupla com Marcelo Nitsche. A proposta, uma seqüência de painéis projetados para os pilares do Elevado Costa e Silva na sua direção leste-oeste, foi apresentada através de um filme em super-8 ${ }^{127}$ realizados pelos artistas em 1974, e executada em 1976.

1. Flavio Motta na banca do concurso para Professor Titular de Vilanova Artigas.

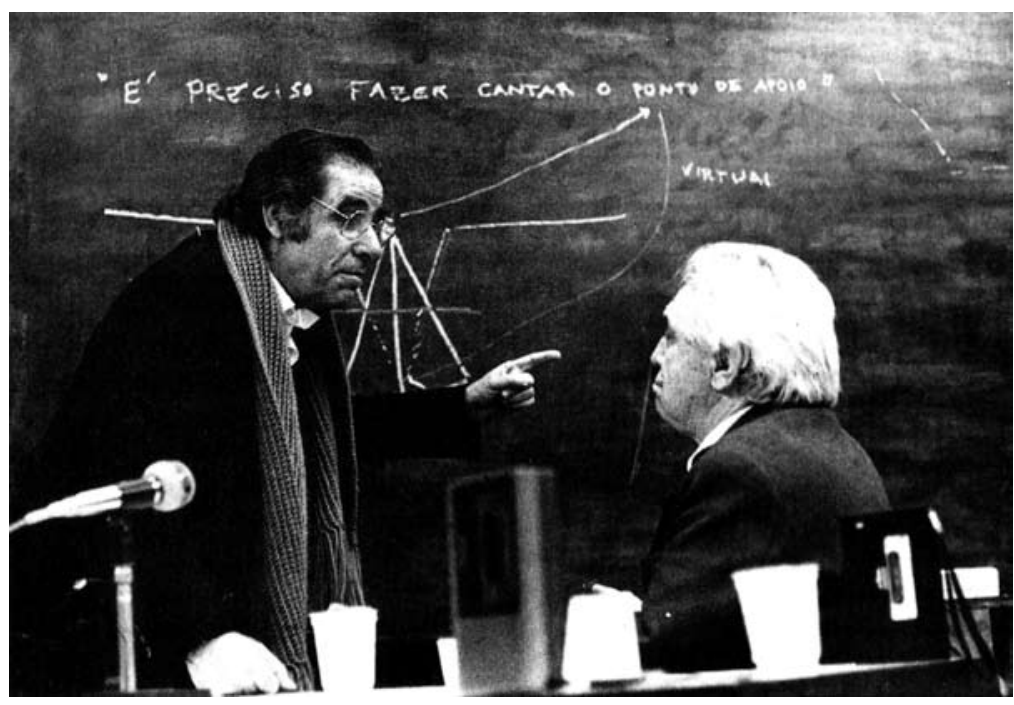

126 Ana Belluzzo, Carmela Gross. São Paulo, CosacNaify, 2000, p.20.

127 "Superfícies habitáveis", filme em S8, COR, 20min28seg, disponível no acervo da Biblioteca da FAUUSP. Além do filme, para a apresentação deste projeto, Flavio Motta publicou dois textos, "Superfícies habitáveis - memorial 1" e "Superfícies habitáveis - memorial 3", em 1976. 
Em 1976 Flavio Motta é convidado a dar aulas na Faculdade de Arquitetura na Universidade Federal do Ceará, onde passa dois anos. Ao retornar a FAUUSP em 1978, apesar dos poucos anos passados, a situação na Faculdade era muito mais desanimadora. Uma sucessão de tentativas de reestruturações curriculares havia transformado o currículo num emaranhado de conteúdos fragmentados ${ }^{128}$, a recusa ao projeto e as transformações que se impunham à atividade do arquiteto, e que não eram acompanhadas por uma escola despedaçada, levavam a um certo esvaziamento das relações no âmbito do ensino, e uma distância do enfrentamento das questões mais atuais. A dificuldade de reintegração dos professores cassados, que voltam para a escola na posição de auxiliares de ensino, refletia a enorme burocratização pela qual a Universidade havia passado nos últimos anos.

Flavio Motta aposentou-se da universidade em 1983, e no ano seguinte foi membro da Banca Examinadora de Vilanova Artigas em seu Concurso para Professor Titular na disciplina de projeto, realizado em junho de 1984, da qual também eram membros os professores Carlos Guilherme Motta, Milton Vargas, José Artur Gianotti e Eduardo Kneese de Mello. Após quatro anos como auxiliar de ensino, o concurso de Artigas realizava-se em meio a um enorme desconforto com a situação constrangedora de submeter a avaliação um professor com a experiência de Artigas, que teve sua cátedra tomada em 1969. Nas palavras de Carlos Guilherme Motta, o concurso tinha também um sentido simbólico: "por intermédio dele podemos rever a luta, o significado da profissão em que tanto se empenharam e se empenham, e que hoje está vivendo como o país, como outras profissões, uma verdadeira encruzilhada"129, e ao mesmo tempo, atestava a "rigidez burocrática" e o corporativismo na universidade.

A argüição de Flavio Motta é sintética e, segundo consta na publicação da ocasião, foi "conduzida por intermédio de desenhos no quadro negro"130. Em seu breve comentário, Flavio relembra a Artigas uma frase de Perret, "é preciso fazer cantar o ponto de apoio". Segundo depoimento recente ${ }^{131}$. Flavio nunca buscou a frase em sua fonte original, ele a conhecia através do próprio Artigas, que freqüentemente a repetia. Ao resgatá-la ao seu interlocutor, acompanhada de algumas poucas perguntas sobre o edifício da FAUUSP, Flavio Motta se diz "aluno" de Artigas, e mais uma vez demonstra sua maneira de sempre manter as questões em aberto, como provocações que permitem desdobramentos e reflexões diversas.

128 Caramelo 6, op.cit., p.18.

129 Carlos Guilherme Motta, "Segunda argüição", A função social do arquiteto. São Paulo, Nobel, 1989, p.42.

130 A função social do arquiteto, op. cit., p.70.

131 Depoimento de Flavio Motta a autora em junho de 2009. 

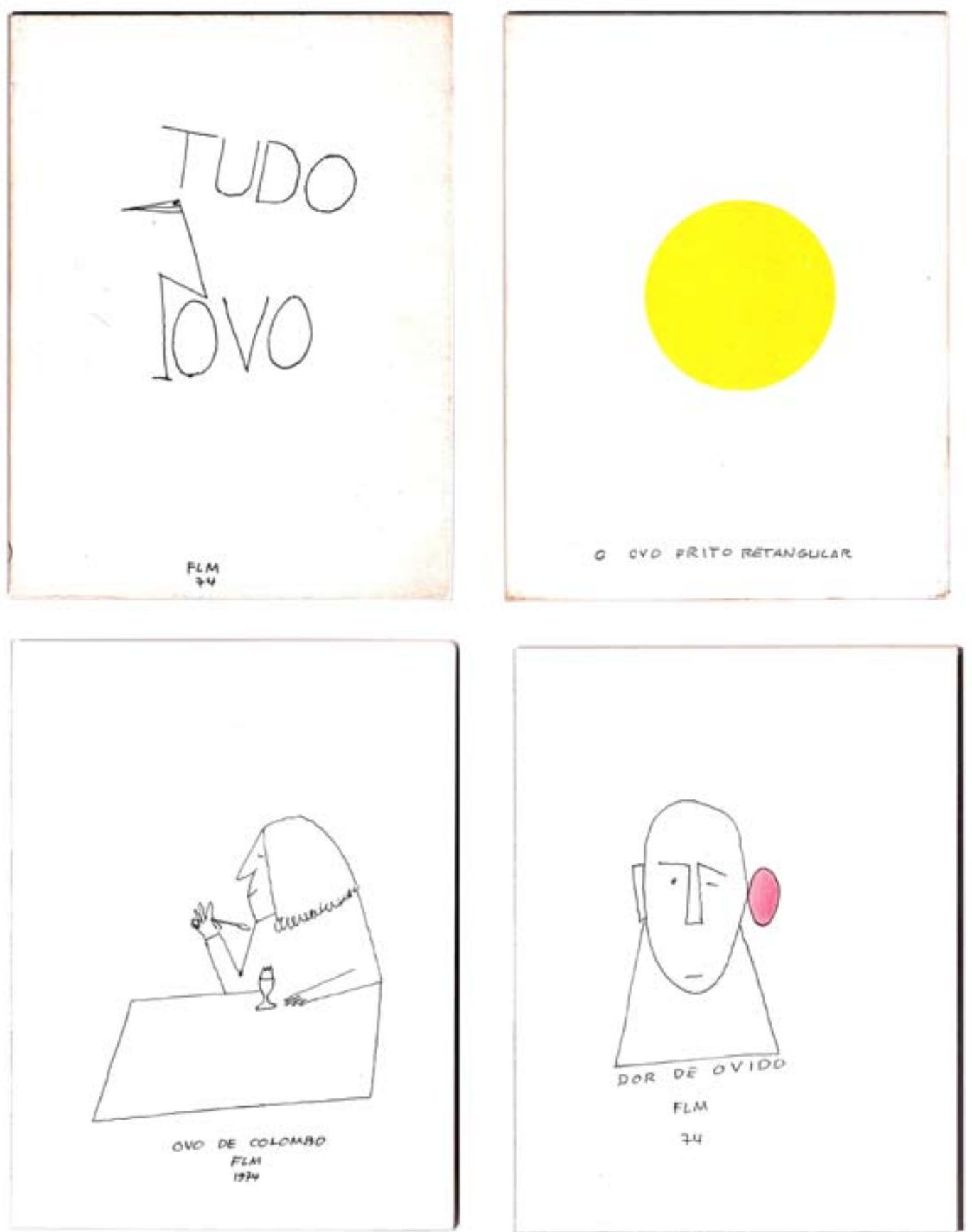

1 a 4. um exemplo dos trabalhos desenvolvidos nas oficinas e na gráfica da FAU durante os anos 70: Tudo novo, livro de desenhos, 1974 / capa, contra-capa e páginas internas. 

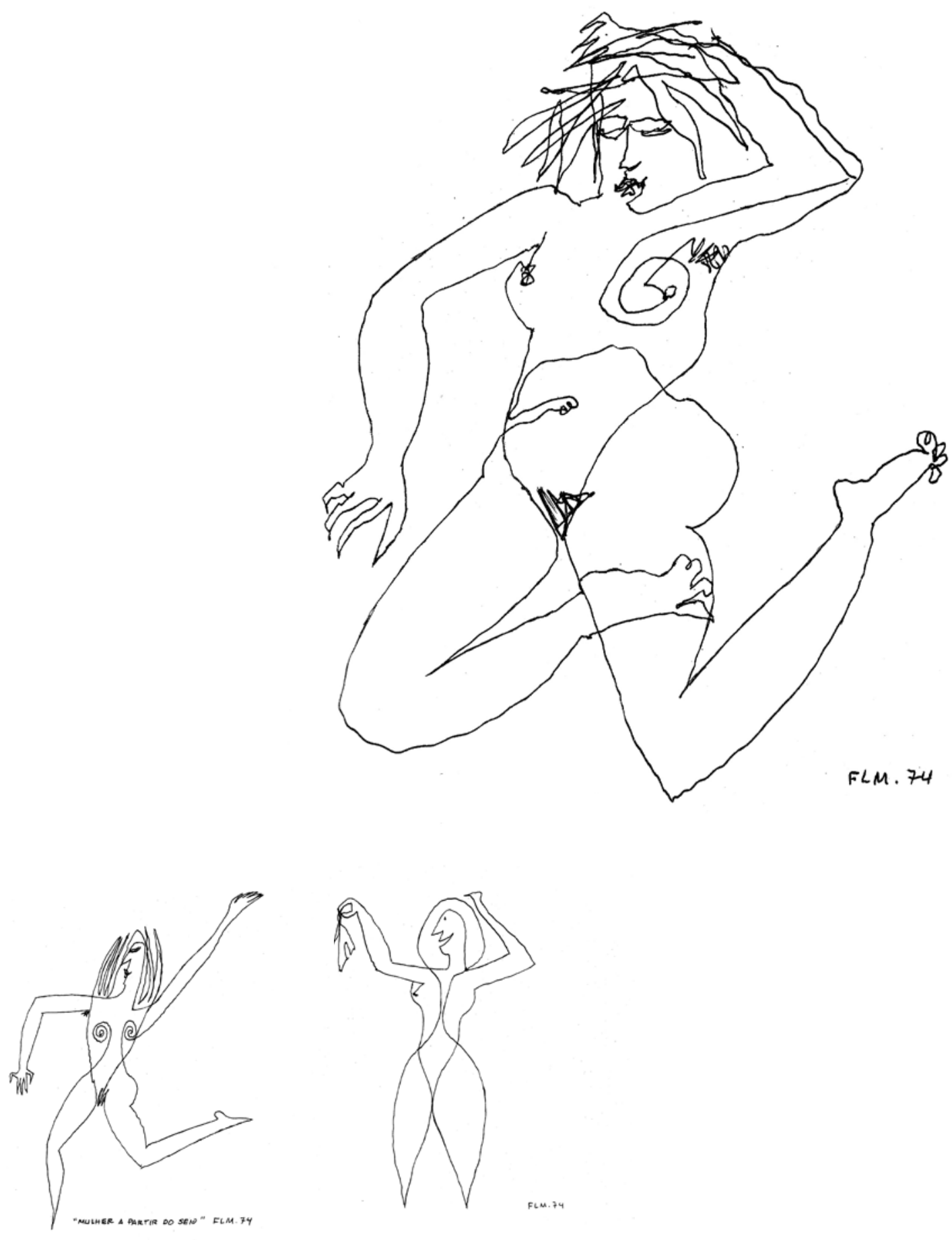

1, 2 e 3. conjunto de desenhos de 1974, "mulher a partir do seio", publicados na revista Módulo n.42, em 1976. 

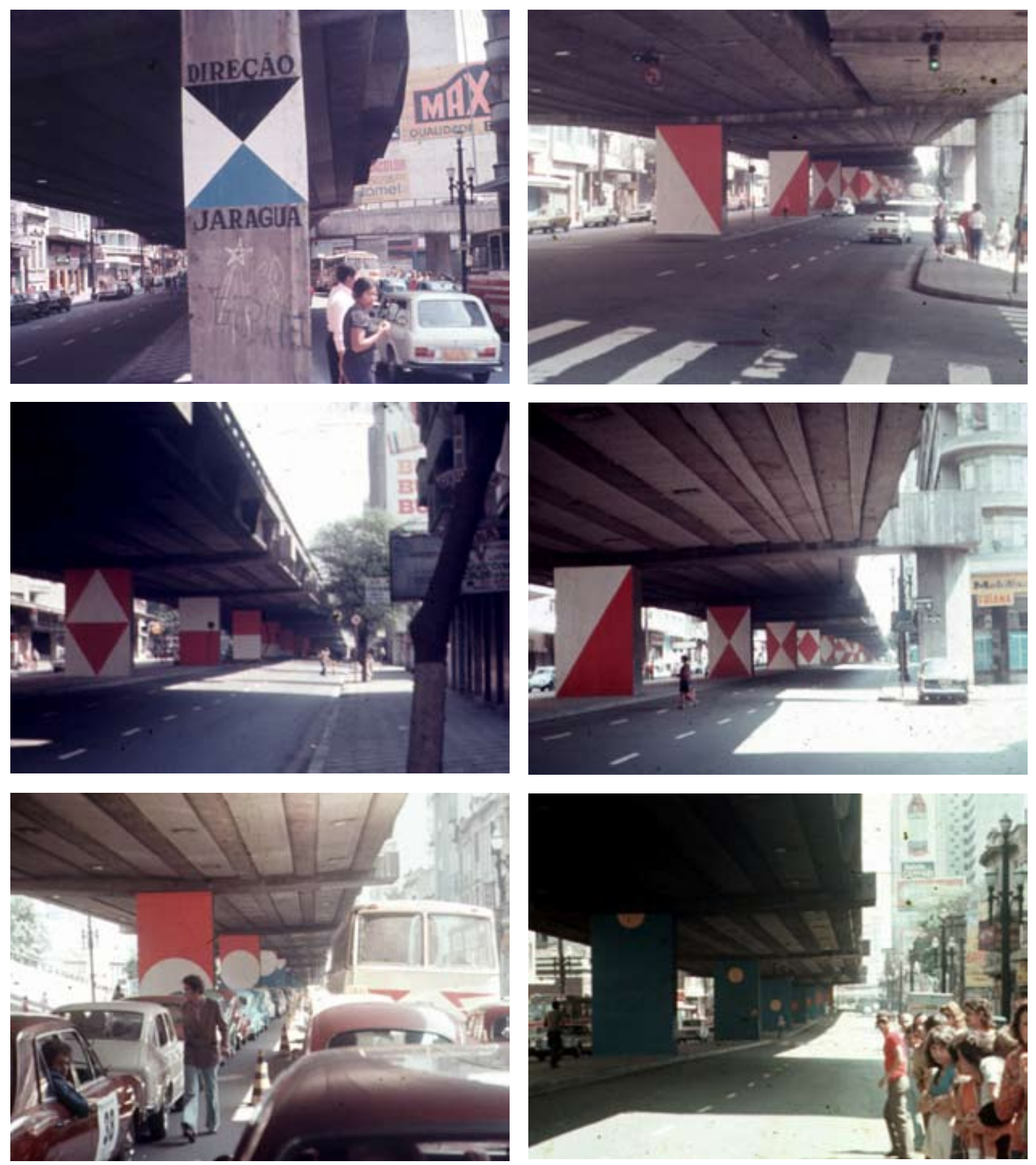

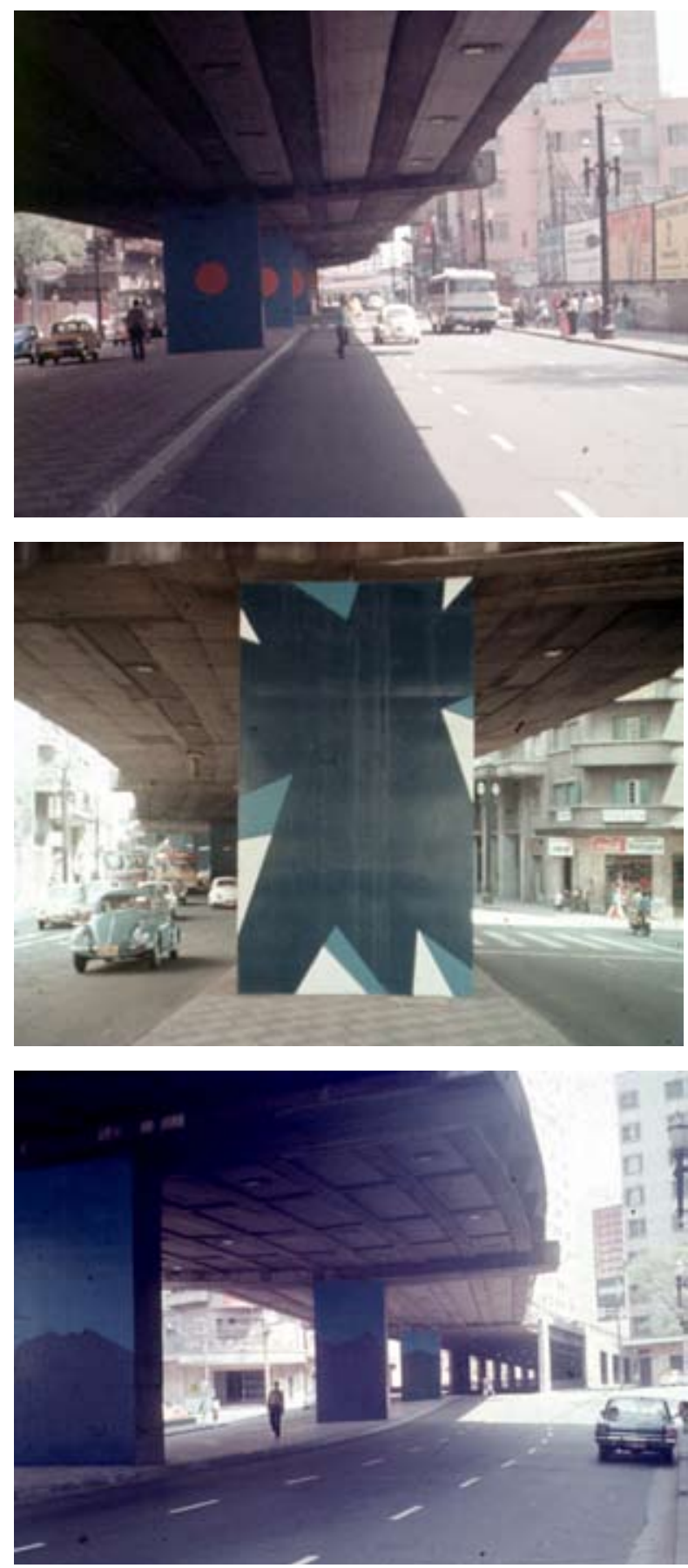

1 a 9. documentação fotográfica dos painéis do Minhocão, logo após ficarem prontos. 



\section{2. do cânone a Zodiac}

Em 1960, ano em que Brasília era inaugurada, a revista italiana Zodiac lançava aquele que seria o último de uma seqüência de números especiais sobre a arquitetura moderna brasileira que vinham sendo publicados no exterior. Ainda que ao longo dos anos 60 algumas revistas eventualmente publicassem algumas edições sobre o Brasil, todas elas passaram ser, a partir desse momento, focadas em Brasília. Pode-se dizer que este número da Zodiac encerra um ciclo na critica e no mercado editorial internacionais especializado, no qual a arquitetura moderna brasileira havia ocupado papel de destaque durante os últimos 20 anos, período em que foram publicados nada menos do que 18 números especiais sobre o país.

Por permitir a discussão do tema da crítica inserida neste quadro mais amplo da historiografia da arquitetura brasileira, estabelecendo diálogos com outros discursos sobre 0 Brasil que se difundiram internacionalmente ao longo da década de 50, este artigo é nosso ponto de partida. Mas também porque o número da Zodiac pontua um novo período que pode ser reconhecido após a construção de Brasília, em que a arquitetura brasileira e a escola carioca de Lucio Costa e Oscar Niemeyer já não são vistas pela crítica internacional com o mesmo deslumbramento da década anterior, e a partir do qual assim chamada "arquitetura paulista" passa a ocupar o centro das pautas editoriais das revistas especializadas locais.

Naquele momento em que se inaugura a nova cidade, a apresentação de outros caminhos possíveis, que fossem distintos do cânone carioca, parece antever um processo de desinteresseque gradativamente recai sobre a arquitetura brasileira por parte da crítica internacional. Pretendemos percorrer alguns dos debates recorrentes desde meados dos anos 50, através do que se publica nas revistas especializadas, que precedem e de certo modo, esclarecem as posições da revista Zodiac e do artigo de Flavio Motta. Pretendemos com isso constituir o campo cultural e intelectual no qual se lançam os arquitetos paulistas a partir da década de 60. 


\section{1. a revista Zodiac e o Rapporto Brasile}

A revista Zodiac era publicada pelo industrial Adriano Olivetti, proprietário da famosa fábrica de máquinas de escrever que havia sido fundada por seu pai na cidade de Ivrea. Considerado por Argan como o principal promotor do design italiano, dedicou-se a promover o desenvolvimento industrial através de novos modelos de organização social do trabalho, durante um período em que o desenho industrial na Itália assumiu um papel de extrema relevância, como elemento promotor de recuperação econômica e "reconstrução cultural" no pós-guerra'. Ao estudar sua trajetória, é possível entendermos a presença de algumas questões nas pautas da revista Zodiac.

Formado engenheiro na Politécnica de Turim em 1924, empreendeu um programa de modernização da empresa que se baseava na "transformação técnica através da intervenção da pesquisa científica sistemática, as novas formas de produção, a organização do trabalho, do comércio, da publicidade, da conduta empresarial"2. Ao mesmo tempo, deu continuidade a uma série de serviços oferecidos aos trabalhadores que haviam sido implementados na fábrica por seu pai: assistência e previdência social, saúde, transportes e escolas, dando início a um programa de construção de novas instalações que reuniam nos arredores da fabrica os escritórios, as habitação dos trabalhadores, cantinas, creches, etc. Através dessas iniciativas, aproximou-se de certo grupo de arquitetos italianos do período, como Luigi Figini e Gino Pollini, que projetaram um conjunto habitacional residencial para os funcionários da empresa em $1937^{3}$.

Em meio às iniciativas de renovação do modo de funcionamento da fábrica, montou, em 1931, um departamento de publicidade na Olivetti, que imediatamente começou a trabalhar com artistas voltados especialmente à esta área. Segundo Argan, a publicidade passava a ter um papel crucial no estabelecimento e aceitação do design e de seus objetos naquele período, e do próprio caráter que o design italiano assume a partir de então. Diversos recursos gráficos, afinados com uma imagem de modernidade, começam a ser aplicados nesses anúncios, proliferando nas revistas do período um padrão visual de alto nível e que tornase uma característica da própria empresa e também das páginas da Zodiac. Entre as novas

1 Giulio Carlo Argan, "O design dos italianos", História da arte como história da cidade. São Paulo: Martins Fontes, 1992, p.269.

2 Carlo Ragghianti, “Adriano Olivetti”, Zodiac, 6, maio, 1960, p.4.

3 Idem, ibidem, p.9. 
tendências visuais que surgem na publicidade do período, Argan destaca particularmente aquela que "repete o objeto com ênfase"4, acentuando a beleza que repercute da própria produção seriada.

Em meio a este processo de renovação da fábrica e de sua imagem através das novas propagandas, e das primeiras experiências de organização do território que desenvolveu com suas próprias instalações, Olivetti se aproximou das questões relativas ao planejamento das cidades $^{5}$. Após algumas experiências junto à equipes que elaboraram alguns planos regionais para o sul da Itália, em 1947 Olivetti fundou o Movimento Comunità. Os princípios desse movimento estavam esboçados no livro L'ordine politico delle comunità ${ }^{6}$, no qual apresentava suas idéias para a organização das cidades, e que havia sido publicado dois anos antes. Este movimento, uma espécie de "república de intelectuais"7 dedicados ao urbanismo e a sociologia urbana, baseava-se na idéia da criação de novos laços políticos, sociais e econômicos entre os governos central e local. Segundo Tafuri, tratava-se de um programa de ação que se inspirava nos modelos urbanísticos anglo-saxões, como as "cidades-jardins" e greenbelt-cities, e os filtrava através da "ideologia olivettiana", tornando-se "matéria de reflexão para as novas experiências"8. Na descrição do próprio Olivetti,

"Se eu pudesse demonstrar que a fábrica era um bem comum e não um interesse privado, seriam justificados a transferência de propriedade, planos reguladores, experimentos sociais audazes de descentralização do trabalho... O modo de equilibrar estas coisas existia, mas não estava em minhas mãos: era necessário criar uma autoridade justa e humana que soubesse conciliar todas essas coisas e 0 interesse de todos. Esta autoridade, para ser eficiente, deveria fazer investimentos de grande poder econômico, deveria, em outra palavras, fazer ao interesse de todos, o que eu fiz no interesse de uma fábrica. Havia apenas uma solução: tornar a fábrica e o ambiente circundante economicamente solidários. Nascia assim a idéia de uma 'Comunità'." 9

4 Giulio Carlo Argan, idem, p.274.

50 envolvimento de Olivetti com o planejamento das cidades está detalhadamente descrito em Carlo Ragghianti, op. cit. pp. 3-13.

6 Adriano Olivetti, L'ordine politico delle Comunità - Le garanzie di libertà in uno Stato socialista. Ivrea: Nuove Edizioni Ivrea, 1945.

7 Manfredo Tafuri, Storia dell'architettura italiana 1944-1985. Turim: Einaudi, 1982, p.27.

8 Idem, ibidem, p.28.

9 Adriano Olivetti, "Appunti per la storia di una fabbrica", citado em Ragghianti, op. cit, p.6. Tradução da autora. 
Em 1946, Olivetti também fundou a Edizioni di Comunità, uma casa editorial voltada principalmente aos temas da política e da ciência, um desdobramento de outras experiências editoriais que vinha tentando manter desde o início da década de 40 e que haviam sido desarticuladas durante a guerra. Em março desse mesmo ano, a editora deu início a publicação da revista Comunità, que foi publicada durante 50 anos. Ainda que a revista e o Movimento fossem instituições independentes, boa parte da produção teórica do Movimento percorreu suas páginas. Nos anos seguintes, a editora cresceu e diversificou seus temas, publicando obras de Friedman, Fromm, Le Corbusier, Lippmann, e em 1957 deu início a publicação da revista Zodiac.

Não era, desse modo, uma surpresa a figura de Adriano Olivetti à frente de uma revista especializada de arquitetura. Mais do que isso, é possível supor que, por sua ligação com os círculos mais progressistas da Itália no período pós-guerra, seu envolvimento com os intelectuais, artistas, arquitetos e designers e seus interesses pelos assuntos relativos à organização da cidade e do território, Olivetti fosse mais do que um financiador da revista, e de fato tivesse uma participação ativa nas pautas e conteúdos editoriais.

No editorial que escreveu para o primeiro número da Zodiac, de outubro de 1957, apresenta as motivações dos editores em criar uma nova revista de arquitetura. Entre elas, estão algumas das idéias que Adriano Olivetti vinha defendendo ao longo dos últimos anos. 0 editorial defende a idéia de que somente através do nascimento de uma nova "comunidade", que emergiria de um processo de "enraizamento" - no sentido de uma aproximação da paisagem, da terra, das tradições, das formas arquitetônicas - é que seria possível superar a "crise nos valores arquitetônicos" e as "incertezas e desorientações" em curso no período"10. E para ele, o surgimento desta nova comunidade viria a responder à duas "necessidades vitais": a primeira é a da criação de uma nova "autoridade" democrática, que não fosse ligada nem ao Estado, nem aos interesses privados, e que fosse estável e capaz de construir a nova cidade. Além disso, a partir da constatação de que "para dar vida a uma nova comunidade" são necessárias muitas gerações, a segunda necessidade a que ele se refere é a de se manter uma continuidade e refinamento do trabalho ao longo do tempo: "A fisionomia da nova cidade não pode ser confiada a um homem, mas a um sistema - uma civilização de cultura descentralizada"11.

Nesse espírito de tentar responder a um quadro de crise profissional, o conteúdo do primeiro número da revista demonstrava a preocupação em compreender o lugar do trabalho

10 Adriano Olivetti, "Una nuova rivista d'architettura", Zodiac, 01, outubro, 1957, p.6.

11 Adriano Olivetti, op.cit., p.6. 
do arquiteto frente os dilemas do período e as "incertezas e desorientações" a que se refere Olivetti. Ao mesmo tempo, mantém-se no caminho seguro da publicação de arquitetos e críticos já consagrados do cânone moderno internacional: a capa do primeiro número traz a foto de Walter Gropius, que também publica nesta edição, pela primeira vez, o célebre texto "Apollo in the Democracy", uma transcrição de seu discurso proferido em junho daquele ano na entrega do prêmio Goethe. O primeiro número trazia ainda artigos de Argan, Gideon e Ernesto Nathan Rogers ${ }^{12}$, além da publicação de projetos de Mies Van Der Rohe, Frank Lloyd Wright e Nervi. Nos anos seguintes, as doze primeiras edições manteriam o mesmo perfil editorial, sob a organização do editor chefe Bruno Alfieri.

Alguns desses arquitetos e críticos constavam na ficha de colaboradores permanentes da revista, que reunia muitas das personalidades atuantes nos debates do período, como Ernesto N. Rogers, Henry-Russell Hitchcock, Sigfried Giedion, Le Corbusier, Eero Saarinen, Paolo Portoguesi, e correspondentes em alguns países fora do circuito compreendido entre a Europa e os Estados Unidos, como México, Venezuela, Japão e Brasil, que no caso, tratava-se de Salvador Candia ${ }^{13}$.

No mesmo sentido das inovações gráficas que haviam sido introduzidas nas propagandas da Olivetti, um dos pontos de destaque na revista Zodiac era seu projeto gráfico primoroso, elaborado por Roberto Sambonet, que ocupava o cargo de diretor de arte da revista, alguns anos após seu retorno do Brasil. Foi ele quem sugeriu a Bruno Alfieri o nome de Flavio Motta para a colaboração no número especial sobre o Brasil. 0 nome de Sambonet aparece nos créditos da resvista como diretor de arte apenas até o número 6 , no entanto, seu padrão para o projeto gráfico permanece sendo usado até o número 12, o último dirigido por Alfieri.

A publicação do número 6 , dedicado ao Brasil, coincide com o falecimento repentino de Adriano Olivetti. A edição traz um texto de abertura que apresenta o percurso de Olivetti, "da construção industrial à ideologia de uma nova sociedade"14. A sobrecapa da revista traz a reprodução de um croqui que Olivetti teria feito alguns anos antes para explicar uma de suas idéias sobre o urbanismo a partir de um exemplo concreto da região Torinense:

"não se podia conseguir um autêntico equilíbrio entre a cidade e o campo senão estendendo a Comunità - elementos da nova articulação político-administrativa da metrópole - aos territórios que compreendiam, ao mesmo tempo, a uma parcela do

12 Giulio Carlo Argan, "Architettura e ideologia"; Sigfried Gideon, "History and the architect"; Ernesto Nathan Rogers "Tradizione e attualità nel disegno", todos publicados na Zodiac 6, op. cit.

13 Apesar de constarem na ficha técnica da revista desde seu número inicial, não há nenhuma indicação ao longo desses primeiros números de quais são as contribuições efetivas de cada um dos colaboradores internacionais.

14 Ragghianti, op. cit. 

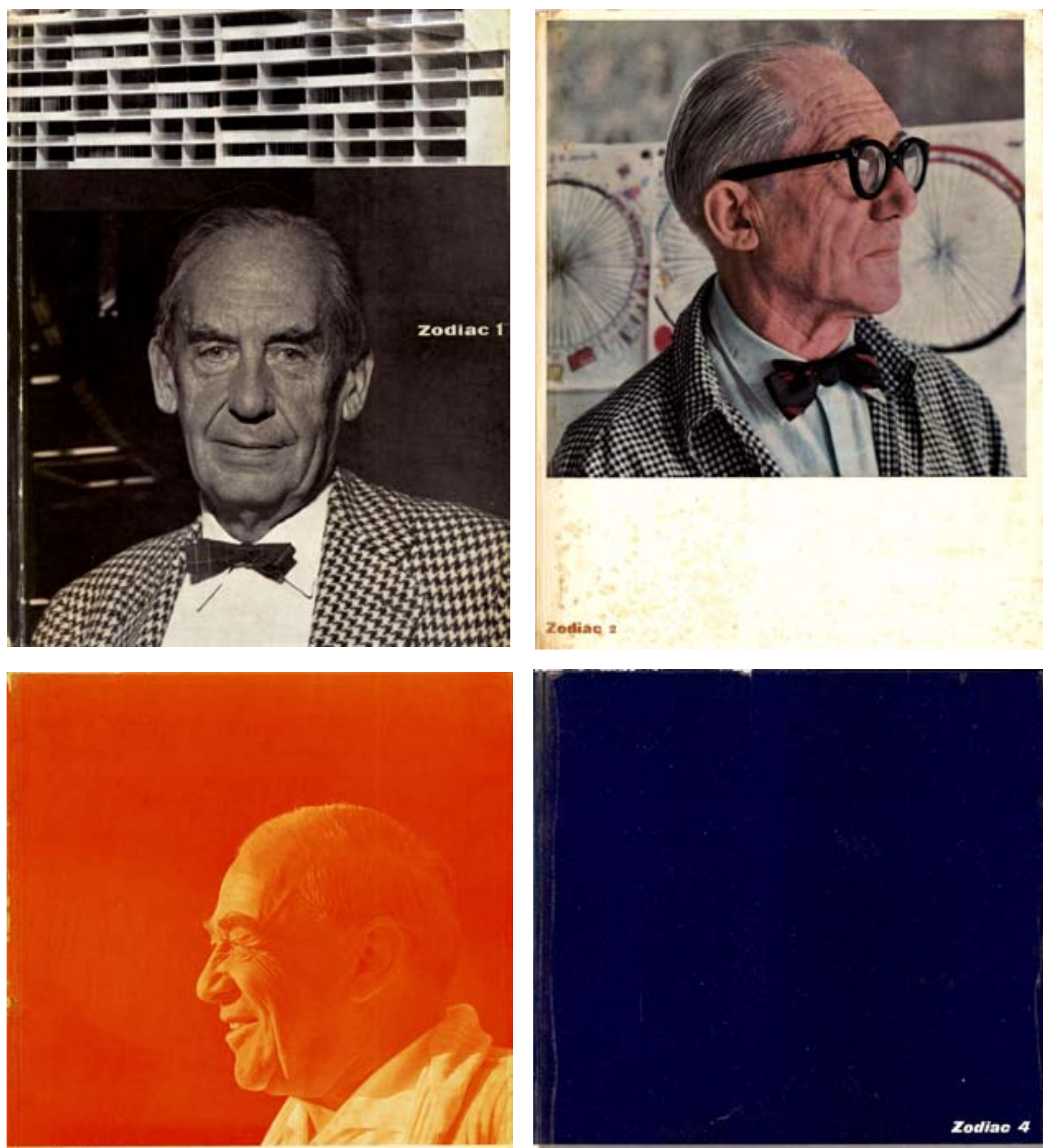

Zodlac 3
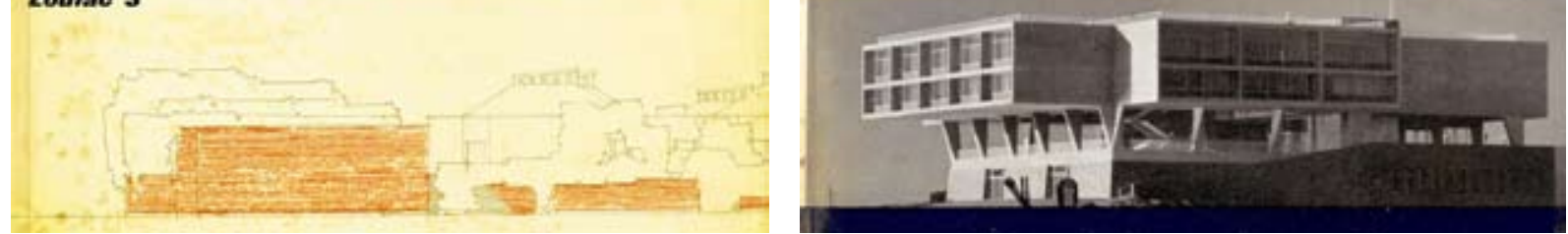
Capas de Roberto Sambonet para a revista Zodiac, números 1 a 6 :

1_ Walter Gropius, novembro de 1957

2_ Le Corbusier, maio de 1958

3_Alvar Aalto, novembro de 1958

4_Eero Saarinen, maio de 1959

5_"arquitetura fantástica" [Frank Lloyd

Wright], novembro de 1959

6 casa de Alvar Aalto, maio de 1960

além dessas capas, os exemplares possuem uma sobrecapa estreita com as informações do conteúdo, da mesma largura da faixa horizontal que é utilizada na diagramação de todas elas.
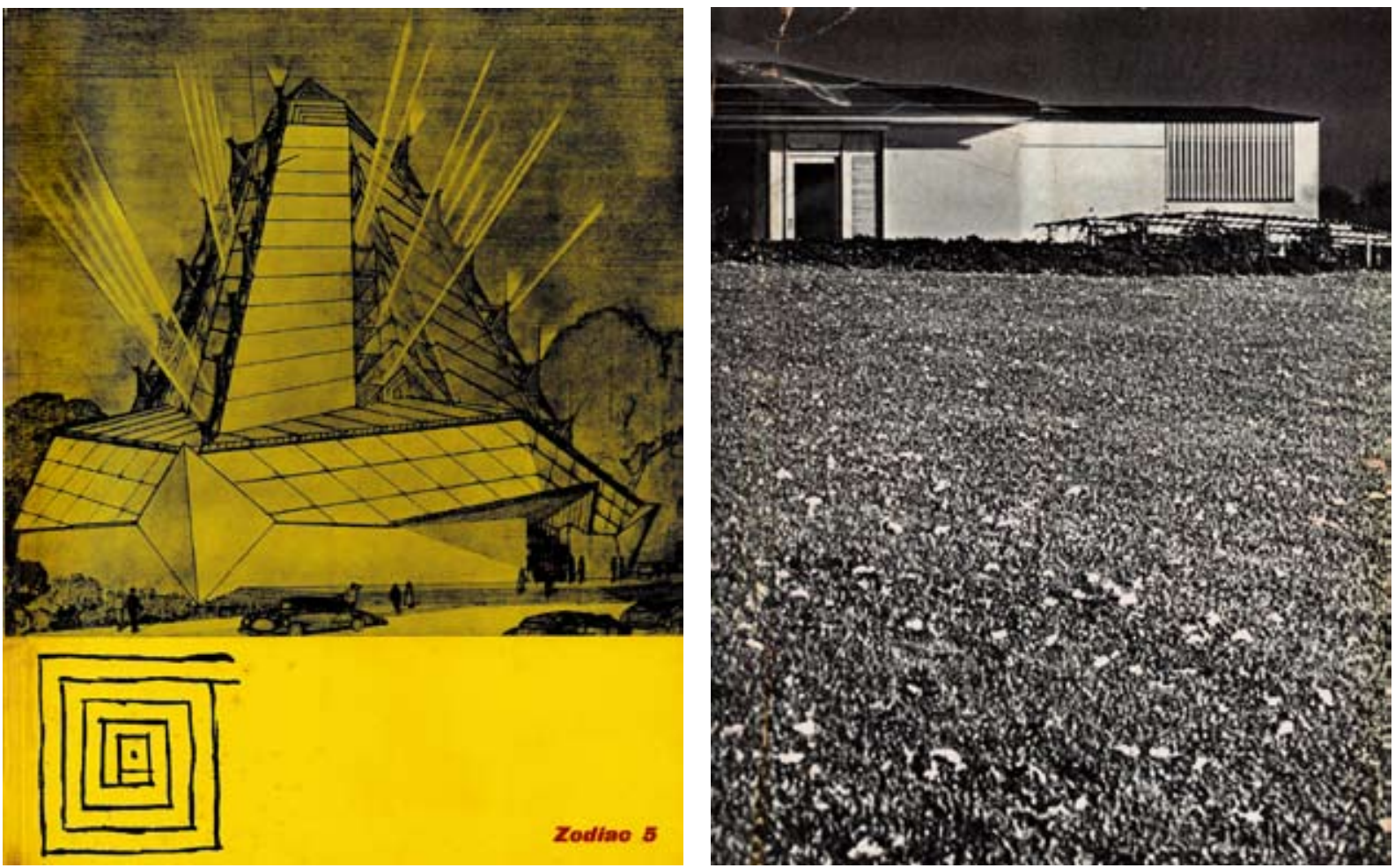


\section{antigo centro asfixiante e do distrito agrícola." 15}

No texto em homenagem ao editor se enfatiza a importância desse exemplo pois, segundo ele, mais do que um valor documental, esse desenho sintetizava a preocupação mais recorrente na "mente política" de Adriano Olivetti: o problema da antítese e das disparidades ente a cidade e o campo. 0 tema permanece e perpassa toda sua trajetória, sua obra escrita, seu percurso como político, urbanista e industrial, direcionando seus interesses na solução dessas diferenças, como "condição básica e preliminar para cada ação possível de reforma e progresso civil" 16 .

Além da homenagem à Olivetti e das 80 páginas dedicadas ao Brasil, o número mantinha o mesmo padrão dos conteúdos das edições anteriores, publicando artigos teóricos de historiadores da arquitetura, como Hitchcock e Rykwert ${ }^{17}$, e apresentando alguns projetos, como uma casa de Alvar Aalto na França - que está na capa do número - e alguns projetos de Carlo Scarpa.

0 conteúdo dedicado ao Brasil, que ocupava maior parte da revista, organizado sob o título de "Rapporto Brasile", tinha o caráter de um número especial tardio. Enquanto as principais revistas internacionais haviam se empenhado na publicação de números especiais sobre o Brasil até meados da década de 50, a Zodiac foi a única a publicá-lo somente ao final da década, desse modo, foi o último número especial sobre a arquitetura moderna brasileira a ser editado ${ }^{18}$. Ainda que a Zodiac tenha sido criada somente em 1957, e a própria editoria tivesse consciência deste "atraso" na pauta brasileira", entendemos que o fato de ter sido publicada nesse outro momento, foi o que definiu uma abordagem das questões apresentadas sob uma perspectiva bastante distinta daquela celebratória, que de um modo geral, permeou os outros números especiais dedicados ao Brasil, publicados ao longo da década de 50. Passado o deslumbramento inicial com a arquitetura brasileira, naquele momento era possível avaliar as experiências precedentes a partir de uma perspectiva mais contundente e ao mesmo tempo, incorporar algumas leituras críticas, não somente acerca do projeto de Brasília, mas também num sentido de um discurso mais afinado com o momento da crítica internacional.

O número especial era apresentado por um texto de autoria do editor chefe. Nele, Alfieri introduz algumas das questões que serão debatidas ao longo do número, especialmente

15 Ricardo Musatti, Zodiac 6, p.06.

16 Idem, ibidem, p.05.

17 Henry-Russel Hitchcock "Notes on a traveler: Wright and Kahn", p.22-47; Joseph Rykwert "Meaning and building", p.193-197, in Zodiac 6, op. cit.

18 Apresentaremos mais detalhadamente a discussão acerca dos "números especiais" no item 2.2

19 "Progettavamo da tempo un "rapporto Brasile" per Zodiac, e l'occasione migliore ci è sembrata il trasferimento della capitale da Rio de Janeiro a Brasilia, che avviene proprio mentre esce questo sesto nunzero della rivista." Bruno Alfieri, "Rapporto brasile", Zodiac 6, p.57. 
a crítica a Brasília. De início, deixa clara a posição de desacordo que a revista assume com relação ao plano da nova cidade:

"Brasília é o resultado de muitos componentes, em sua maioria políticos, o que deixa uma pequena margem para o planejamento urbano entendido como uma técnica moderna do campo da arquitetura. [...] Brasília é mais uma oportunidade perdida, uma oportunidade que sacrificou a boa e afiada dialética de Costa e o fértil instinto de Niemeyer; um monumentalismo parcialmente justificado - vamos tentar evitar ser moralistas a qualquer custo! - pelos objetivos políticos do grande plano, com os quais nenhuma pessoa sensata pode concordar; não obstante, nos planos cultural e técnico, ainda é monumental, ou seja, a tradução de componentes extraartísticos em símbolos artificiais" ${ }^{20}$.

Não é uma surpresa o rigor com o qual a revista avalia a nova cidade, frente ao quadro dos debates internacionais naquele momento. Ao mesmo tempo, essa crítica também pode ser entendida a partir do envolvimento de Olivetti com o planejamento urbano e o modo de organização do território que o editor defendia e praticava. Para alguém que defendia que os planos urbanos fossem pensados levando em conta a articulação entre campo e cidade, entre governos locais e poder central, próximos a idéia das "cidades-jardins", efetivamente a proposta para Brasília estava em desacordo com seus princípios.

Além desse breve editorial e do o texto de apresentação "Introduzione al Brasile", de Flavio Motta, que é objeto de nosso estudo, o número especial sobre o Brasil trazia como conteúdo apresentações detalhadas do trabalho de alguns arquitetos brasileiros: Afonso Reidy, Rino Levi, Vilanova Artigas, os irmãos Marcelo e Milton Roberto e Burle Marx. E fechava a edição marcando a posição da editoria no debate acerca de Brasília, com a publicação de um pequeno dossiê: um artigo de Bruno Zevi, "Critica a Brasilia"; o "Depoimento" de Oscar Niemeyer, em tom de defesa da crítica a que era submetido; e um último artigo de autoria de Mario Barata, "Ponto de vista de um brasileiro", que fechava a edição dedicada ao Brasil. 


\section{2. a recepção internacional da arquitetura brasileira}

A arquitetura moderna brasileira começa a ser efetivamente publicada nas revistas internacionais a partir do projeto do Ministério da Educação e Saúde em 1936 e do Pavilhão Brasileiro para a Feira de Nova York em 1939. Até então, poucas referências sobre este tema podem ser encontradas: foram publicados apenas 12 artigos que tratavam da arquitetura brasileira desde 1900, que tinham como assunto temas e períodos variados. É somente a partir do projeto do ministério e do Pavilhão da Feira de NY, que cresce o interesse internacional por esta que parecia ser uma experiência mais consistente de arquitetura moderna fora do eixo central de difusão desse movimento. Como um retrato desse aumento de interesse, é possível verificarmos um aumento significativo do número de referências publicadas sobre o Brasil, que entre os anos de 1936 e 1942 somam 16 artigos ${ }^{21}$. Até esse momento, essas iniciativas são consideradas manifestações pontuais de nível excepcional, realizadas sob a inspiração de Le Corbusier após sua visita ao país. Aos olhos estrangeiros, essas iniciativas primeiras somente ganham ares de movimento estruturado e consciente a partir de sua reunião na publicação do catálogo Brazil Builds e na exposição no MoMA em 1943.

Por esse apanhado geral, é possível percebermos que, quando se trata de compreender a inserção da arquitetura moderna brasileira nos temas e debates da crítica internacional, as revistas especializadas representam um material de extrema importância. É através delas que mais claramente percebemos como se avalia, o que se valoriza e de que modo se insere à arquitetura brasileira no âmbito das discussões mais gerais do movimento moderno. Através das revistas, é possível perceber mais de perto as relações entre a crítica e o campo profissional da arquitetura, a medida em que a produção projetual é relacionada aos debates em curso e ao campo cultural mais amplo.

Neste sentido, o discurso crítico empreendido em cada uma delas assume papel chave no processo de produção da arquitetura, pois acaba por resultar em efeitos concretos, diretos, muitas vezes contemporâneos às próprias realizações, tanto ao atribuir significados e valores a cada obra, quanto ao delinear os caminhos profissionais, disciplinares ou projetuais possíveis de serem traçados. Por essa razão, as revistas não significam apenas documentos de cada período, mas também constituem importante material historiográfico, a medida que fornecem 
elementos e representações que alimentam os debates no calor do momento, e desse modo contribuem para a consolidação de determinadas narrativas.

Uma evidência dessa importância é a significativa quantidade de trabalhos acadêmicos realizados recentemente com o foco na contribuição das revistas na constituição da arquitetura moderna brasileira e sua contribuição à historiografia ${ }^{22}$. Tais trabalhos nos ajudaram tanto a reconhecer o peso relativo de tal ou qual periódico, e sua relevância para este estudo, como a definir os recortes temporais e temáticos que estabelecemos. Mais do que isso, foram fontes importantes ao entendimento das orientações editoriais e estruturas de funcionamento de algumas das revistas, e seu fortalecimento ou inconstância editorial em certos períodos.

O número especial sobre o Brasil da revista Zodiac insere-se num conjunto de publicações de mesmo caráter, que começaram a ser publicadas a medida em que, no plano internacional, o interesse pelo Brasil tornou-se crescente. Os chamados números especiais são aqueles que concentram uma série de projetos numa única edição, e a partir dos quais é possível delinearmos um discurso crítico mais preciso, pois não se trata de um somente um projeto apresentado entre tantos outros, mas sim da escolha e elaboração de uma narrativa acerca do Brasil e da arquitetura brasileira. No sentido de compreender as particularidades da publicação da Zodiac e do texto de Flavio Motta, empreendemos um estudo acerca dos números especiais sobre o Brasil publicados durante esse período ${ }^{23}$.

0 interesse pelos números especiais também se justifica a partir de seu caráter editorial: neles, elege-se o que determinada revista considera o mais representativo ou mais importante dentre aquela determinada produção, e deste modo, configura-se um quadro que, ao mesmo tempo que apresenta ao público este olhar particular de cada revista, também, como documento historiográfico, nos mostra qual o discurso que se pretendia construir, e sob quais aspectos aquela determinada arquitetura interessava aos debates e questionamentos

22 São eles: Maria Beatriz Capello. Arquitetura em Revista: arquitetura moderna no Brasil e sua recepção nas revistas francesas, inglesas e italianas (1945-1960). São Paulo: FAU-USP, 2006 (Tese de doutorado); Clara Luiza Miranda. Crítica nas revistas de arquitetura nos anos 50: a expressão plástica e a síntese das artes. São Carlos, EESC-USP, 1998 (Dissertação de mestrado); Nelci Tinem. O alvo do olhar estrangeiro: o Brasil na historiografia da arquitetura moderna. João Pessoa: Editora Universitária, 2006; Paula Dedecca, Crítica paulista de arquitetura carioca: recepção e diferenciação da produção brasileira moderna nas revistas especializadas de São Paulo (1945-1960). São Paulo: FAUUSP, 2006 (Iniciação científica).

23 A metodologia adotada para o levantamento baseou-se principalmente no índice de periódicos internacionais disponível na biblioteca da FAUUSP (Index: a cumulative author and subject index to selected list of fin arts and periodicals. NY), e quando possível, alguns índices disponíveis na internet (Avery Index to architectural periodicals, NY, Columbia University Libraries; RIBA - Royal Institute of British Architects, Catalogue. Londres) A partir desse levantamento inicial, foi possível complementar esta pesquisa com algumas visitas ao acervo da biblioteca Avery, da Columbia University, e desse modo ter acesso aos números que não estão disponíveis no Brasil. Com isso, foi possível mapearmos todos os números especiais publicados sobre o Brasil neste período, e delinear este quadro com mais precisão. 
Capas de alguns dos números especiais sobre o Brasil publicados entre 1943 e 1960:

1_ New Pencil Points, janeiro, 1943.

2_Architectural Record, n.1, v.93, janeiro, 1943.

3_The Studio, n.607, v.126, outubro, 1943.

4_The Architectural Review, n.567, v. 95, março, 1944.

5_L'Architecture D'Aujourd'Hui, n.13-14, v. 18, setembro, 1947.

6_ The Architectural Forum, n.5, v. 87, novembro, 1947.

7_Proa, n.11, abril, 1948.

8_ The Architectural Review, n.646, v.108, dezembro, 1950.

9_L' Architecture d'aujourd'hui, n.xx, v.23, agosto, 1952.

10_ The Architectural Review, n.679, v.114, julho, 1953.

11_ The Architectural Review, n.694, v.116, outubro, 1954.

12_Arquitectura Mexico, n.64, v.14, dezembro, 1958.
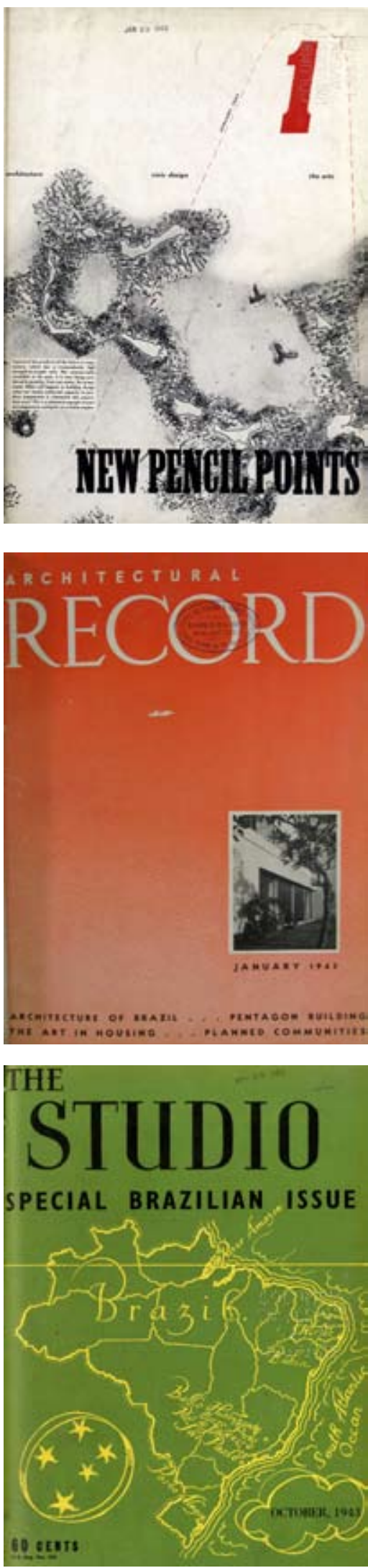

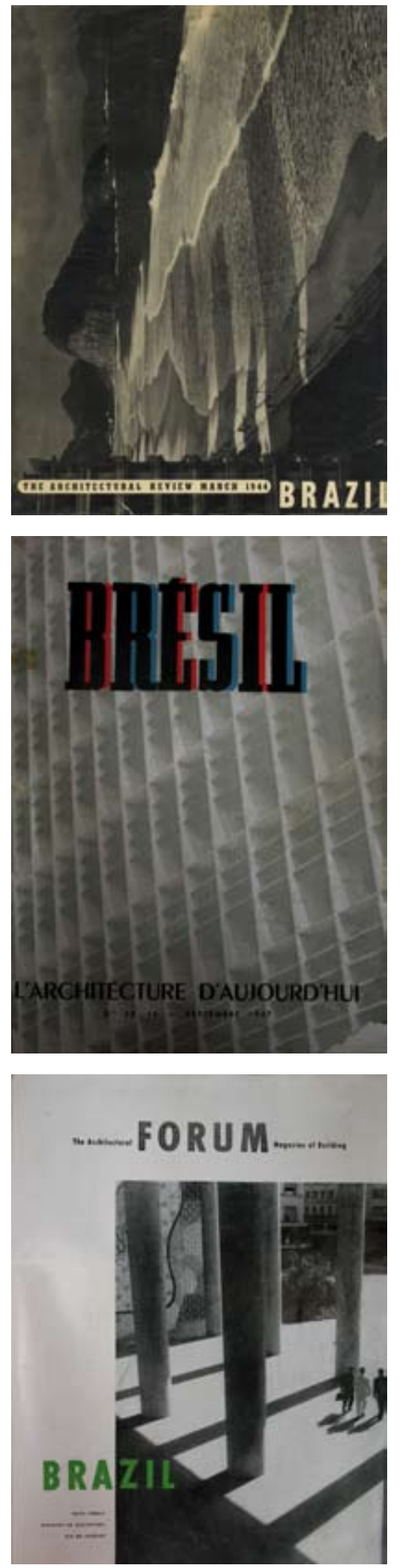
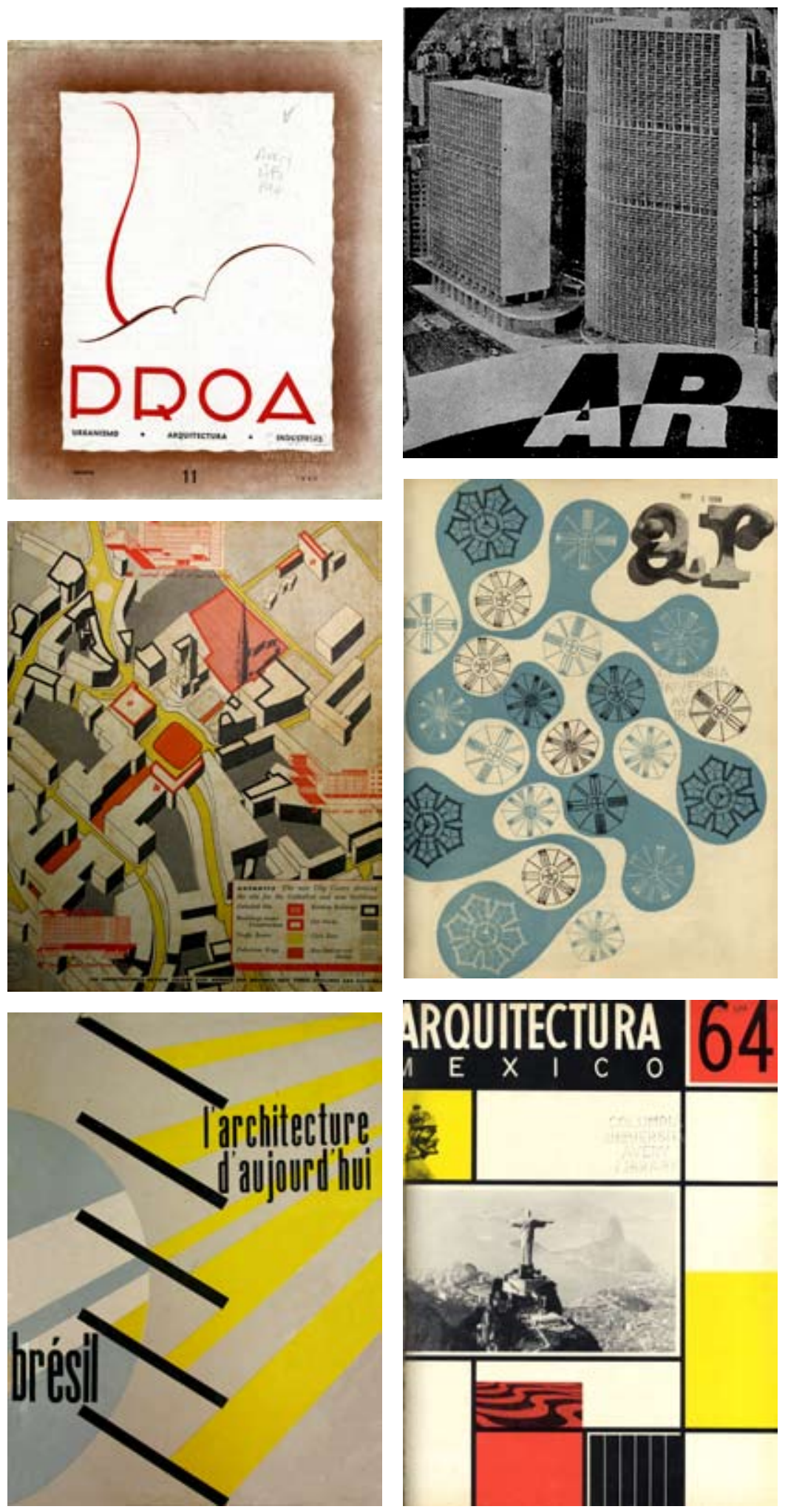
acerca do movimento moderno internacional ${ }^{24}$.

Ao estudarmos a crítica da arquitetura brasileira neste quadro internacional a partir do conteúdo das revistas, o ponto de partida é o ano da publicação do catálogo Brazil Builds, 1943. Neste ano aparecem os primeiros números especiais sobre o Brasil, que tem início nas revistas americanas Architectural Record e New Pencil Points no mês de janeiro, e posteriormente na Europa, na revista inglesa The Studio, em outubro. Esses números são o ponto de partida para uma verdadeira explosão de artigos que sobre o Brasil vindos das mais diversas procedências ${ }^{25}$. Somente no ano de lançamento do livro foram publicados 15 artigos focados na arquitetura brasileira e 3 números especiais. Entre sua edição, em 1943, até 1960 as revistas estrangeiras publicaram nada menos do que 224 artigos sobre arquitetura brasileira, e neste conjunto, um total de 19 números especiais sobre o Brasil em todo o mundo ${ }^{26}$. No início da década de 50 a arquitetura brasileira já é um tema regular nessas revistas, e atinge seu período de maior prestígio no quadro internacional.

Mais do que responsável pelo bem-sucedido reconhecimento internacional da arquitetura brasileira, a publicação de Brazil Builds representa também o início de uma matriz de leitura que seria incorporada à historiografia da arquitetura brasileira deste momento em diante. Partindo dos trabalhos que reconstituem a formação de uma "trama historiográfica" 27 da arquitetura brasileira, sabemos que a narrativa instituída a partir do livro Brazil Builds, será sistematicamente reiterada nos manuais de arquitetura moderna, na divulgação da arquitetura brasileira nas décadas seguintes, e também através do conteúdo publicado a partir de 1943 nas revistas especializadas.

Nesta construção, sabemos que algumas estruturas comparecem de modo recorrente nessas leituras. Através delas, se organiza um quadro a partir do qual a arquitetura moderna

24 Alguns dos trabalhos estudados também concentram-se apenas nos números especiais. 0 trabalho de Nelci Tinem trata dos seguintes: L'architecture d'aujourd hui, n. 13-14, 1947, e n. 42-43, 1952; Architectural review, n. 567, 1944; Architectural Forum, n.11, 1947. Já no trabalho de Beatriz Capello, os números especiais estudados são: The studio, out. 1943; Architectural review, n. 567, 1944; L'architecture d'aujourd hui, n. 13-14, 1947, e n. 42-43, 1952.

25 Além daqueles países que configuram o eixo principal de discussão do movimento moderno, como os Estados Unidos e os centros europeus, encontramos também publicações de números especiais sobre o Brasil vindos da Colômbia, do México, da África do Sul, etc.

26 Os números especiais levantados durante a pesquisa são: Architectural Record, jan. 1943; The studio, out. 1943; Architectural review, mar. 1944; Byggmastaren, n.19, 1946; Progressive Architecture, abr. 1947; L'architecture d'aujourd hui, n. 13-14, 1947; Architectural Forum, n.11, 1947; Proa, abr. 1948; Domus, n.229, 1948; Architectural review, out. 1950; L'architecture d'aujourd hui, n. 42-43, 1952; Architectural review, jul. 1953; Werk, n.8, 1953; Architectural review, out. 1954; L'architecture d'aujourd hui, n. 67-68, 1956; Architectural Record, abr. 1956; Arquitectura Mexico, n.21, 1958; L'architecture d'aujourd hui, jun-jul. 1960; Zodiac, n.6, 1960.

27 A principal referência na discussão da elaboração da "trama" da historiografia brasileira, é o trabalho de Carlos A. Ferreira Martins, Elementos para uma análise da constituição do discurso moderno no Brasil. A obra de Lucio Costa 1924-52. São Paulo: FFLCH-USP, 1988 (Dissertação de mestrado). Entretanto, a partir dele, podemos citar outros trabalhos que contribuem para esta discussão, como o de Nelci Tinem apontado em nota anterior. 
estabelece uma relação de continuidade com uma arquitetura tradicional brasileira, que por sua vez corresponde a uma adaptação local - a partir das disponibilidades técnicas e das necessidades climáticas - da arquitetura colonial. Este processo de continuidade, interrompido pelo neoclassicismo e ecletismo, é retomado pelo grupo que se articula em torno de Lucio Costa após sua passagem pela direção da ENBA, em 1931, e que realiza o projeto do Ministério da Educação. Ainda que realizado sob o risco de Le Corbusier, trata-se de uma adequação às condições locais, e portanto, uma contribuição original brasileira ao movimento moderno internacional ${ }^{28}$. A partir do projeto do Ministério a arquitetura moderna brasileira - entendida como aquela realizada pelo grupo de Lucio Costa, com Oscar Niemeyer como principal figura desenvolve-se num crescente, vinculada ao estado como produção "oficial", e se afirma como linguagem nacional.

Como uma visão mais geral da crítica empreendida nos números especiais, é possível percebermos que nos primeiros, especialmente aqueles publicados em 1943 e 1944, o material apresentado nas revistas é praticamente idêntico aquele publicado no catálogo Brazil Builds, muitas vezes utilizando as mesmas fotos de Kidder-Smith ou até mesmo os painéis completos da exposição ${ }^{29}$. A medida em que cresce o interesse pelo tema, as revistas começam a enviar correspondentes para a realização de novos levantamentos, e conseqüentemente a diversificar os projetos apresentados, entretanto são raríssimas as apresentações de projetos que fogem ao cânone carioca. É possível localizar em meio às obras de Niemeyer, Lucio Costa, M.M. Roberto, Reidy, Alcides da Rocha Miranda, Francisco Bolonha, Atílio Correia Lima, Jorge Moreira, Henrique Mindlin, algumas poucas exceções a este grupo, na maioria das vezes, na presença de Rino Levi e Kneese de Mello. Ainda assim, as leituras empreendidas tendem a apaziguar qualquer possibilidade que escape a matriz mais geral, nesse sentido, os projetos que representariam uma dissonância desta trama são inseridos na mesma chave interpretativa. Outro ponto em comum a essas publicações é que, na grande maioria dos casos, o teor do comentário dessa produção é elogioso, valorizando as características peculiares do movimento brasileiro e sua capacidade de contribuir ao quadro internacional ${ }^{30}$.

De um modo geral, os números especiais sobre o Brasil reafirmam e valorizam um único modo de leitura e conseqüentemente, contribuem para que se consolide como a "versão canônica" da constituição da arquitetura moderna brasileira. De fato, não se pode dizer que esses periódicos estivessem intencionalmente comprometidos com a afirmação de uma trama

28 Carlos A. Ferreira Martins. Elementos para uma análise da constituição do discurso moderno no Brasil. A obra de Lucio Costa 1924-52. São Paulo: FFLCH-USP, 1988, pp.73-74.

29 É o caso, por exemplo, das duas primeiras revistas, The Studio, 1943, e The Architectural Review, 1944, op. cit.

30 A exceção a esta postura elogiosa é a revista The Architectural Review, de 1954, sobre a qual trataremos no item seguinte deste capítulo. 
histórica, entretanto, através da amplitude de seu alcance, acabam por afirmar tendências e servir de fonte aos ensaios monográficos e manuais que desde então começaram a aparecer no exterior acerca desta questão. ${ }^{31}$

\section{3. a crítica dos anos 50}

No início dos anos 50 recai sob os arquitetos a primeira crítica severa ao movimento que vinha até aquele momento sendo reiteradamente elogiado. Max Bill, em 1953, dá início a um incômodo debate.

Era a primeira vez que Max Bill visitava o país, ainda que fosse conhecido no campo cultural local desde da primeira exposição retrospectiva de sua obra, realizada no MASP em 1951, e tivesse recebido o prêmio da I Bienal de São Paulo nesse mesmo ano. Sua presença, "de prestigiada a incômoda"32, perturbou o campo intelectual local com a publicação de uma entrevista concedida ao jornalista e crítico de arte Flavio de Aquino na revista Manchete em junho de 1953. Nessa entrevista, ainda que pese certa nota sensacionalista deste veículo, Max Bill não poupava comentários depreciativos aos projetos que até este momento eram considerados os melhores exemplos da arquitetura que vinha sendo celebrada internacionalmente. As conhecidas críticas de Max Bill recaíram justamente sobre o edifício do MEC, a cidade do Rio de Janeiro, os murais de azulejo, e causaram certo constrangimento em muitos dos arquitetos locais. ${ }^{33} \mathrm{~A}$ resposta mais contundente, nas semanas seguintes, veio de Lucio Costa, na mesma revista Manchete, com o artigo "Oportunidade perdida", no qual o autor, em resposta à acusação de "barroquismo" que Max Bill fez à arquitetura brasileira, publica a também conhecida declaração: "pois se trata no caso de um barroquismo de legítima e pura filiação que bem mostra não descendermos de relojoeiros, mas de fabricantes

31 Nelci Tinem. $O$ alvo do olhar estrangeiro: o Brasil na historiografia da arquitetura moderna. João Pessoa: Editora Universitária, 2006, p.203.

32 Em sua tese, Ana Luisa Nobre apresenta um relato detalhado da visita de Max Bill ao país, esclarecendo, também, a usual confusão de datas desta visita e as Bienais. Ana LuizaNobre. Fios cortantes: projeto e produto, arquitetura e design no Rio de Janeiro (1950-1970). Rio de Janeiro, PPGHSC, PUC-Rio, 2008 (Tese de doutorado).Ver especialmente p.24-27.

33 Carlos Leão, Eduardo Corona, Jorge Moreira foram alguns dos que responderam a estas críticas durante as semanas que seguiram a sua publicação. 
de igrejas barrocas" ${ }^{34}$. Declaração que ao mesmo tempo atingia o arquiteto e artista suíço, em seus postulados ultra-funcionalistas, quanto a dependência exclusiva da arquitetura brasileira em relação a obra de Le Corbusier.

Alguns dias antes da publicação da entrevista, Max Bill havia também apresentado conferência na FAU-USP na qual, ainda que mantivesse as mesmas posturas críticas que havia manifestado na entrevista, tinha espaço e oportunidade para esclarecer suas posições, e aparentemente tentar desfazer possíveis mal-entendidos.

Em sua apresentação, organiza um discurso no qual enumera aquilo que considera os elementos que vinham sendo utilizados indiscriminadamente pelos arquitetos brasileiros, que "materializam o que chamarei de 'espírito acadêmico modernizado'. [...] tornaram-se meras fórmulas, aplicadas sem reflexão ou razão." Esses elementos, segundo ele, eram aqueles que justamente caracterizavam a vertente arquitetônica difundida por Le Corbusier: a forma livre, a cortina de vidro, o brise-soleil e finalmente, o pilotis. Neste último elemento, sua crítica é implacável, chegando ao ponto de dizer que preferia o edifício do Ministério da Guerra ao MEC, comentário que muito repercutiu no campo cultural do período, que muito havia se empenhado no combate ao ecletismo representado por esse edifício ${ }^{35}$. Por fim, após um ataque direto a uma obra de Niemeyer que havia visitado ${ }^{36}$, diz-se

"estupefato de ver uma barbárie como esta irromper num país onde há um grupo do CIAM, num país onde acontecem Congressos Internacionais de Arquitetura Moderna, onde uma revista como a Habitat é publicada e onde se realiza uma Bienal de Arquitetura. Pois tais obras nasceram de um espírito desprovido de qualquer decência e de qualquer responsabilidade com as necessidades humanas. É o espírito decorativo, algo diametralmente oposto ao espírito que anima a arquitetura, que é a arte da construção, arte social por excelência."37

Não era por acaso a menção de Max Bill a revista Habitat em meio às instituições que ele considerava respeitáveis no Brasil. 0 grupo da Habitat mantinha relação com o suíço há algum tempo. Claramente vinculada editorialmente ao MASP, principalmente até a primeira metade da década de 50, a revista dirigida por Lina Bo e Pietro Maria Bardi, era parte de

34 Lucio Costa, 1962. Citado em Hugo Segawa, Arquiteturas no Brasil, 1900-1990, p.258-259.

35 A declaração de Max Bill pela "preferência" ao Ministério da Guerra foi, segundo depoimento de Flavio Motta, tomada como a maior ofensa que o visitante poderia ter feito naquele momento, num meio onde a arquitetura moderna se estabelecera às custas de muito combate frente ao ecletismo que o Ministério da Guerra representava. Flavio ressalta, entretanto, que Max Bill apenas queria chamar a atenção para outras tipologias - que não o pilotis - do que exatamente de defender aquela arquitetura: "devemos portanto procurar novas formas, adequadas às condições sob as quais vivemos, tirando partido das virtudes dos pátios enquanto nos livramos de seus defeitos. Seria um recurso mais adequado do que substituí-los por edifícios em forma de "caixas sobre pilares." Max Bill, "O arquiteto, a arquitetura e a sociedade". Depoimentos de uma geração. São Paulo: Cosac Naify, p.160.

36 O edifício Califórnia, no centro de São Paulo. Ver Ana Luisa Nobre, op. cit.

37 Max Bill, op. cit., p.161. 
um projeto de ação cultural idealizado pelo casal e compartilhado por seu pequeno grupo editorial, no qual Flavio Motta ocupava o cargo de diretor da revista. ${ }^{38}$

Acompanhando a divulgação da exposição do artista suíço no MASP em $1951^{39}$, Habitat havia publicado uma crítica elogiosa de sua obra "Unidade Tripartida", e na mesma edição, o artigo de Max Bill "Beleza provinda da função e beleza como função", no qual "discute a responsabilidade a que a forma estaria submetida, seu sentido social e, em contrapartida, o desejo de chegar a uma nova expressão formal". ${ }^{40} \mathrm{~A}$ polêmica entrevista concedida a revista Manchete, foi republicada na Habitat alguns meses depois. Os editores da Habitat saem em defesa de Max Bill, que àquela altura vinha sendo sistematicamente desqualificado no meio arquitetônico brasileiro, reiterando sua concordância com as críticas e tentando recuperar a importância intelectual de Max Bill, e da atividade crítica para o "amadurecimento da produção brasileira, a fim de evitar seu ingresso numa rotina acadêmica a que Bruno Zevi já fazia referência em seu livro Historia da Arquitetura Moderna" ${ }^{41}$. No ano seguinte, Habitat ainda publicaria a conferência ministrada na FAUUSP, "O arquiteto, a arquitetura e a sociedade".

De fato, diferentemente de todas as demais revistas brasileiras de arquitetura, a revista Habitat mantinha, desde seus primeiros números, uma posição de certo antagonismo à "arquitetura da expressão plástica centrada na criatividade pessoal do arquiteto", publicando artigos que debatessem este tema desde o início de sua atividade editorial ${ }^{42}$. Segundo Fabiana Stuchi, a "escolha por uma arquitetura em que os valores morais, como a racionalidade construtiva, e a adequação a função, estariam à frente das questões plásticas e formais se explica ao retomarmos o percurso na Itália de Pietro e Lina" e suas ligações com os grupos racionalistas europeus. Habitat, desde o primeiro número destaca seu interesse por uma arquitetura que apresente uma "função artisticamente social", em detrimento das expressões individualistas.

Além disso, em artigo publicado em 1951, Lina Bo Bardi já fazia advertências que iam de encontro ao teor da crítica que Max Bill faria anos depois: chamava a atenção para o risco

38 Sobre a revista e suas relações com o MASP, ver Fabiana Terenzi Stuchi. Revista Habitat: um olhar moderno sobre os anos 50 em São Paulo. Dissertação de mestrado, FAUUSP, 2007. Discutiremos mais detalhadamente o envolvimento de Flavio Motta com o MASP e a revista Habitat no segundo capítulo da dissertação.

39 Em depoimento à autora, Flavio Motta conta que foi responsável pela montagem dessa exposição no museu, a qual acompanhou pessoalmente, com a ajuda de Alexandre Wollner, então aluno dos cursos do IAC. Depoimento de Flavio Motta em 17/06/09.

40 Max Bill, "Beleza provinda da função e beleza como função", Habitat n.2, p.61-65, 1951.

41 Fabiana Stuchi, op. cit., p.106; ver também a esse respeito Paula Dedecca, Crítica paulista de arquitetura carioca. Relatório final de iniciação científica / CNPQ. São Paulo, 2006.

42 É o caso, por exemplo, do artigo de Pietro Maria Bardi, "Problemas do barroco: a religião e a curva", Habitat n.1, 1950. Citado em Clara Miranda, op. cit., p.82. 
da arquitetura brasileira se transformar em mais um "estilo" ${ }^{43}$, pois para ela, o abandono do antigo pelo moderno poderia ser responsável por um processo no qual somente as formas seriam absorvidas, e não seus valores e significados. Segundo Fabiana Stuchi, o alerta dos editores de Habitat para o risco de "academização" e decadência da arquitetura moderna brasileira, cuja conseqüência seria um esgotamento prematuro, no entanto, não era voltado à reprodução das formas pela arquitetura anônima que disseminava pilares em $\mathrm{V}$ e brise-soleil, mas sim pela produção realizada pelos mesmos arquitetos que a fizeram ser destaque. ${ }^{44}$

Nesse sentido, a publicação da crítica de Max Bill se insere num conjunto de sucessivas advertências, que tiveram lugar nas páginas da revista, através de artigos de Lina, Abelardo de Souza, Gropius e do próprio Bill, e que, segundo Stuchi, são complementados pela "eleição e publicação de uma produção de arquitetura que fizesse honrar o título de moderna", qual seja, aquela que para o corpo editorial da revista, apresentasse os princípios de uma arquitetura "artisticamente social":

“As relações entre modernidade e brasilidade presente na produção moderna brasileira são valorizadas com os princípios internacionais que convivem ao lado de elementos e experiências que particularizam essa produção como nacional. [..] São os princípios da racionalidade, da simplicidade, do respeito às técnicas construtivas, ao clima e aos costumes, que une a produção contemporânea à arquitetura popular,45

O edifício do MEC é tomado como um símbolo dessa arquitetura, pois de acordo com a revista, os elementos que o caracterizavam "devem ser lidos como o respeito às características e condições locais, e portanto, empregados com viés técnico e não estético", e nesse sentido, coerentes, de tal forma que a revista sai em defesa da arquitetura nacional já em 1951, dirigindo-se à crítica européia:

“[... não concordamos entretanto sobre o fato de que a arquitetura brasileira já marca estrada para uma academia, como já as vezes aparece em algumas revistas estrangeiras, como por exemplo no livro importante de Bruno Zevi; e não a marcará até quando seu espírito será o espirito do homem, sua pesquisa, a busca dos valores

43 Lina Bo Bardi, "Bela criança". Habitat n.2, 1951, p.3.

44 Stuchi, op. cit., p.99.

45 Idem, ibidem, p.102. 
da sua vida em evolução, até quando colherá sua inspiração da poesia íntima da terra brasileira; estes valores na arquitetura contemporânea brasileira existem. ${ }^{\prime 46}$

Ainda que discordem da possibilidade de que a arquitetura moderna brasileira houvesse se transformado num exercício acadêmico - como, além de Zevi, o próprio Max Bill irá alertar em sua conferência ${ }^{47}$ - pode-se dizer que as posições do corpo editorial da revista desde 0 início dos anos 50 vão de encontro às opiniões manifestadas por Max Bill na ocasião de sua visita, incluindo nesta leitura a crítica à arquitetura como expressão individual, que começava a sofrer acusações de formalismo já no início dos anos 50:

"No Brasil, porém, há indícios de que muitos arquitetos, alguns de renome, fazem um grande esforço, não de inteligência, mas de exibição.[...] Entrou em voga a moda de fazer formas ao invés de construir casas. Ao invés de estudar o emprego funcional dos materiais, inventa-se o emprego plástico dos materiais, a fim de adaptá-los a garatujas, ângulos, cotovelos, losangos. [...] Em determinado sentido é este um aspecto de barroquismo, desde que entendemos por barroco, não o atribuído de grandiosa circunstância histórica, mas o vírus de uma baixa cultura, que convida a viagens ao reino da extravagância, do insípido, do inútil, do incoerente enfim." 48

Desse modo, não é uma surpresa o fato de que a revista Habitat foi um dos poucos veículos ligados aos arquitetos que não tentou desqualificar Max Bill e suas opiniões, e nem mesmo rebater às críticas do suíço. Enquanto alguns questionavam a competência de Max Bill, outros justificavam suas opiniões a uma dificuldade de compreensão, seja do idioma ou da distância cultural que não permitia ao suíço entender a arquitetura produzida sob as características nacionais. Ao contrário, Habitat procurava trazer ao centro da discussão a importância de Max Bill e relevância de sua obra, e além disso defender a possibilidade da existência da crítica no campo arquitetônico e sua importância, sem que fosse recebida no plano pessoal, como era o hábito da crítica arquitetônica brasileira.

Flavio Motta, comentando a polêmica provocada pela crítica de Max Bill, relatou que na ocasião, entendeu a crítica de Max Bill muito mais como um ataque à vertente corbusiana do que propriamente uma crítica tão depreciativa à arquitetura local. Para ele, tratava-se muito mais de uma tentativa de emplacar alternativas, 'outra' arquitetura moderna que não

46 Lina Bo Bardi, op. cit. p.3.

47 "a arquitetura brasileira corre o risco de cair em um perigoso academicismo anti-social". Max Bill, op.cit., p.159.

48 Lina Bo Bardi, "construir com simplicidade". Habitat n.7, 1952, p.15. 
era necessariamente a vertente corbuseriana, do que propriamente desprezar a arquitetura brasileira. Segundo ele, a "disputa" de Max Bill era na Europa, o suíço não tinha nenhuma razão direta para depreciar a arquitetura brasileira daquele modo, sua intenção era a de que sua crítica repercutisse em solo europeu. Segundo Flavio, desdenhar publicamente daquela arquitetura que havia alcançado sucesso internacional, talvez representasse para Bill uma chance de voltar às atenções a outras possibilidades e à sua proposta projetual, muito distinta daquela de Le Corbusier. ${ }^{49}$

De fato, a crítica de Max Bill repercutiu também no exterior. A transcrição da palestra proferida aos estudantes da FAUUSP foi publicada no número especial da Architectural Review, de outubro de 1954. A edição trazia uma série de textos comentando o estado atual da arquitetura brasileira. Tratava-se do primeiro número especial que deixava de lado o tom deslumbrado e publicava, ainda que dentro de um quadro mais panorâmico de projetos, algumas opiniões bastante desfavoráveis a respeito da arquitetura brasileira. Segundo a própria revista, foi possível compor este quadro devido as visitas realizadas por ocasião da II Bienal de São Paulo, na qual muitos arquitetos e críticos internacionais estiveram presentes. Por essa razão, apresentava-se como o primeiro "retrato qualificado" da situação arquitetônica no país desde a visita de Goodwin e Kidder-Smith ${ }^{50}$. Além disso, assim como Max Bill quando chegou ao país, o editorial reclamava de que até então, tudo o que se conhecia da arquitetura brasileira era através das publicações nas revistas; como se a visita das obras in-loco trouxesse uma grande surpresa aos que estavam acostumados as belas imagens de Brazil Builds.

A edição trazia, junto com a conferência transcrita de Max Bill, as impressões de Walter Gropius e Ernesto Nathan Rogers ${ }^{51}$. Gropius apresenta uma visão mais precavida, sem nenhuma crítica direta à arquitetura ou aos arquitetos brasileiros, criticando apenas a ausência de planejamento nas cidades. Encerra seu depoimento com o célebre comentário que dá título ao artigo: com relação a arquitetura brasileira, não se tratava "de uma moda passageira, mas de um vigoroso movimento" 52 . 0 artigo de Rogers é uma versão resumida do que havia sido publicado alguns meses antes na revista Casabella, da qual ele era editor-chefe. "Pretextos por uma crítica não formalista" trazia sua visão própria da crítica e seus métodos, refutando tanto

49 Depoimento de Flavio Motta a autora, em 17/06/09.

50 "Our trouble is the lack of authoritative eye-witnesses, for Brazil is a boom-province of the Modern Movement which the Movement's master have hardly visited since Le Corbusier lent his authority and support to the pioneer efforts of Costa and Warchavchik in the 'thirties; and since the definitive reports of Goodwin and Kidder-Smith in Brazil Builds, we have to rely on photographs and inflated newspaper stories which seem to bear no relation to one another, nor to the situation as Philip Goodwin left it." Architectural Review, n.694, p.235.

51 Cada um dos artigos citados foram republicados na reedição da coletânea Depoimentos de uma geração, organizada por Alberto Xavier, sob o título "Confrontações - olhar estrangeiro". São Paulo, Cosac Naify, 2003.

52 Walter Gropius, "Um vigoroso movimento". Depoimentos de uma geração, São Paulo, Cosac Naify, 2003, p.154 
o juízo de Max Bill quanto o de Gideon com relação à arquitetura brasileira, que por seguirem critérios preestabelecidos, acabam os próprios críticos assumindo uma postura formalista:

"Se a crítica deve ser justamente severa ao tachar de formalismo aquelas obras cuja aparência não seja motivada por razões internas e circunstanciais, da mesma forma deve ser tida como formalista aquela crítica que, influenciada por opiniões apriorísticas, não for capaz de penetrar no significado das obras rompendo a crosta do gosto subjetivo. [...] É um erro crítico que ousaria incluir na categoria do formalismo o fato de comparar com as próprias preferências poéticas o resultado estético que um artista alcança por ser fiel à poética que Ihe é inata." ${ }^{3}$

A divergência entre Bill e Rogers nesta ocasião se estendeu por outros caminhos, provocando uma resposta de Max Bill as acusações de Rogers, e envolvendo também Bruno Zevi, que saiu em defesa de Bill, compondo uma verdadeira polêmica que se estendeu nas páginas de Casabella e Architectural Review no ano seguinte. ${ }^{54}$

A resposta local às seguidas acusações de formalismo por parte da crítica internacional partiu do corpo editorial da revista carioca Módulo, que conforme destaca Hugo Segawa, dedicou seu primeiro número à rebater os críticos estrangeiros: "Somos um povo jovem, com uma tradição de cultura ainda em formação - o que nos expõe naturalmente mais à crítica daqueles que se julgam representantes de uma civilização superior"55. 0 corpo editorial da Módulo tenta depreciar Max Bill e Ernest Nathan Rogers, pondo em cheque sua competência profissional, afirmando que suas eram autores de "pequenos e inexpressivos projetos". De acordo com o modo que se tornaria recorrente como resposta às críticas formuladas contra a arquitetura brasileira - sem debater diretamente a crítica, recorre-se ao plano pessoal e a depreciação do autor como arquiteto.

A crítica de Max Bill e seus desdobramentos representaram um ponto de inflexão numa trajetória que até este momento se encontrava ascendente. Seu significado maior, no contexto que apresentamos, é demarcar um período no qual há uma mudança de olhar para a arquitetura brasileira, que a partir de então passa a ser vista com mais ressalvas, sem a celebração da década anterior. Esse momento coincide também com uma certa crise na arquitetura da escola carioca, que além da desconfiança internacional, começa também a ser

53 Ernesto Nathan Rogers, "Pretextos por uma crítica não formalista". Depoimentos de uma geração, São Paulo, Cosac Naify, 2003, p.168.

54 a esse respeito, ver Tinem, op. cit., p.202, e Nobre, op. cit., p.191.

55 Oscar Niemeyer, Módulo, n.1, 1955, p.47 
questionada no plano local.

Pouco mais de uma década após Brazil Builds, as indagações e cobranças se proliferavam, muitas delas no mesmo sentido da crítica de Max Bill, chamando atenção para a reprodução automática de soluções formais já consagradas, descambando para o "academicismo". No mesmo sentido dos alertas publicados na Habitat no início da década, outras vozes cobravam qual seria o próximo passo daquela arquitetura que já havia superado a "fase heróica". É o caso, por exemplo, de Luis Saia, que em 1954 publicou nos jornais paulistas um alerta que praticamente parafraseava a conferência de Max Bill:

“as cartas do atual 'baralhão' são poucas e fáceis, eficientes e rendosas; meia dúzia de soluções formais e algumas palavras de poder mágico: 'brise-soleil', 'colunas em V', 'pilotis', 'amebas', 'panos contínuos de vidro', 'moderno', 'funcional' etc. $O$ prestígio dessas formas e dessas palavras e o seu abuso, sonegam a consideração justa dos problemas que realmente são propostos pelo trato mais consentâneo da nossa arquitetura". 56

Além da tendência ao academicismo, outra crítica recorrente à arquitetura moderna brasileira era a pouca quantidade de obras de caráter social e a distância dos arquitetos dos problemas relacionados ao crescimento desordenado das cidades brasileiras. A crítica dava ênfase a ausência de planejamento e às condições precárias das cidades, a especulação imobiliária e ao desequilíbrio da estrutura social, frente as quais os arquitetos se mantinham inertes ${ }^{57}$. A exceção a esta condição era o conjunto Pedregulho, de Reidy, que recebia aprovação unânime dos críticos mais ferrenhos, inclusive de Max Bill.

Esse distanciamento que, de um modo geral, a arquitetura do grupo carioca mantinha dos problemas nacionais era reconhecido até mesmo por um arquiteto conservador e intimamente ligado ao grupo como Henrique Mindlin. Como exemplo dessa crítica, Hugo Segawa transcreve depoimento de Mindlin de 1945, muito anterior às críticas que proliferaram nos anos 50: "Falta-nos a visão concreta, realizada na prática, dos grandes problemas sociais da coletividade. Faltam-nos habitações populares, faltam-nos escolas, hospitais, locais

56 Luiz Saia, "A fase heróica da arquitetura contemporânea brasileira já foi esgotada há alguns anos". Depoimentos de uma geração, São Paulo, Cosac Naify, 2003, p.228.

57 Até mesmo um entusiasta da arquitetura moderna brasileira como Gideon, chamava atenção para essas deficiências: "O Brasil é uma país de contrastes, resultado de um período febril de especulação. Barracos toscos brotam como cogumelos nos terrenos baldios das grandes cidades e nos lotes absurdamente caros da sua periferia. Nenhum equilíbrio de estrutura social e nenhum planejamento urbano em grande escala serão possíveis sem que esse quadro financeiro caótico seja superado." "O Brasil e a arquitetura contemporânea". Depoimentos de uma geração, São Paulo, Cosac Naify, 2003, p.156. 
decentes de trabalho. Faltam-nos, sobretudo, um urbanismo de sentido social, um urbanismo voltado para as necessidades do povo". ${ }^{58}$

Compreender as razões da dificuldade de aceitação da crítica por parte dos arquitetos brasileiros também possibilita a construção de um retrato bastante significativo da situação cultural e dos debates em curso naquele momento. Nesse sentido, a pesquisa de Ana Luisa Nobre é particularmente elucidativa:

"Tudo indica que no centro do debate que emergia naquele momento, travava-se, na verdade, de uma discussão mais ampla sobre diferentes modos de pensar os desdobramentos do projeto moderno após a guerra. Não seria difícil ver na forte resistência que o pensamento de Max Bill encontrou em arquitetos como Lucio Costa, por exemplo, um progressivo desgaste das bases sobre as quais a arquitetura moderna no Brasil vinha sendo sustentada publicamente desde os anos 30. Porque se a definição de moderno no Brasil dos anos 30 podia ainda se confundir, e até se limitar à oposição ao ecletismo acadêmico, o pós-guerra exigia o enfrentamento de toda uma outra ordem de problemas: do colapso do racionalismo à difusão de novas técnicas e materiais, da aceleração das taxas de urbanização à expansão do capitalismo industrial. Problemas estes aos quais, no nosso caso, vinha somarse ainda o acirramento de debates político-econômicos envolvendo a condição de subdesenvolvimento do país e o papel do Estado na industrialização." 59

De certo modo, no plano local, havia a expectativa de que a inauguração de Brasília promovesse a retomada do lugar do Brasil entre os protagonistas do movimento arquitetônico do período, e nesse sentido, adquiria especial significado a realização da edição extraordinária do Congresso Internacional dos Críticos de Arte na cidade, passando também por São Paulo e Rio de Janeiro.

58 Henrique Mindlin, citado em Segawa, op. cit., p.172.

59 Ana Luisa Nobre, op. cit., p.23. 


\section{4. introduzione al Brasile na revista Zodiac}

Em dissonância com a matriz de leitura que era repetidamente reiterada, o artigo de Flavio Motta, "Introduzione al Brasile", apresenta um quadro histórico que tem início na transição do Império à República, destacando as características políticas e econômicas desses dois períodos e sua relação com a produção cultural e o desenvolvimento no campo artístico. Na medida em que problematiza esta relação, insere o desenvolvimento da arquitetura moderna brasileira num quadro muito mais complexo do que aquele que até então era promovido no plano internacional.

Como observa Clara Miranda,

"A crítica de Flavio Motta na Zodiac aponta os equívocos da consideração da enxertia da linguagem corbusiana e Pampulha como momento de gênese da arquitetura moderna brasileira. Motta contrapõe-se à ideologia do estímulo como "momento fundante" da generalização da linguagem moderna no país, e coloca a idéia de uma introdução feita de um somatório de trabalhos e discursos. Absorve implicitamente a idéia do aspecto não-revolucionário da arquitetura moderna como um todo, mas de um produto da condensação de sucessivas reestruturações técnicas, metodológicas e lingüísticas, em cuja difusão, o discurso tem papel fundamental, ao superpor ao mundo das técnicas e do fazer novos significados, novas relações humanas, impedindo que se tornem recorrentes ou desdobrando o significado daqueles que têm valor." 60

Nesse quadro, não permite, por exemplo, que se recorra à leitura ordinária de que o ecletismo e o neo-classicismo teriam representado um momento de interrupção da força criativa e da expressão local ${ }^{61}$, ao contrário, destaca a importância do período para "0 despertar do espírito nacional"62 e a abertura de novas possibilidades na vida artística e literária nas cidades, e ainda o progresso qualitativo no ensino e na construção com a criação da Escola Nacional de Belas Artes: "Centralizando a vida cultural do país, a cidade do Rio

60 Clara Luiza Miranda. Crítica nas revistas de arquitetura nos anos 50: a expressão plástica e a síntese das artes. São Carlos: EESC-USP, 1998, p.260.

61 Flavio Motta já se dedicava desde 1953 ao estudo da contribuição dos movimentos artísticos do final século XIX, quando publicou na revista habitat o artigo "São Paulo e o Art-Noveau". Habitat, São Paulo, v.10, p. 3-18, 1953, que posteriormente desenvolveu como sua tese para concurso de cátedra na FAUUSP, Contribuição ao Estudo do Art-Noveau no Brasil. Tese para concurso de cátedra. São Paulo, FAUUSP, 1957.

62 Flavio Motta, “Introduzione al Brasile". Zodiac, Milão, n.6, 1960, p.64. 
de Janeiro e com ela a Academia com todos os seus rigores formais, serviam aos ideais de unidade do Império"63.

Não é à toa que Flavio Motta, em seu artigo, dedica especial atenção à questão do ensino e da formação profissional. Este tema aparece de modo recorrente no artigo, ora na discussão da importância da educação pública no desenvolvimento econômico e industrial, ora destacando a presença do Liceu de Artes e Ofícios na produção artística e no campo da construção em São Paulo, ou na preocupação com a formação técnica dos arquitetos.

Além do tema do ensino, outra questão presente na leitura empreendida por Flavio Motta, é o equilíbrio entre as cidades de São Paulo e Rio de Janeiro, no que tange à introdução da arquitetura moderna no Brasil. Essa discussão novamente retoma alguns debates anteriores relativos à constituição da matriz de leitura canônica da arquitetura moderna brasileira.

Os estudos que tratam dessa constituição consideram o livro sobre o arquiteto Gregori Warchavchik publicado em 1965 por Geraldo Ferraz ${ }^{64}$ como a primeira iniciativa em desacordo com o esquema instituído e celebrado a partir de Brazil Builds, na medida em que pretendeu construir uma trama distinta. Nela, não só é reforçada a importância de Warchavchik como pioneiro da arquitetura moderna, mas principalmente a "mudança de enfoque na abordagem da história de uma arquitetura brasileira". ${ }^{65}$ Se na versão cristalizada que parte de Brazil Builds a arquitetura moderna era vista a partir de uma ótica de continuidade de um projeto nacional, a partir de seu vínculo com a tradição nacional e colonial em particular, a linha construída por Geraldo Ferraz tenta recuperar um sentido internacional da arquitetura moderna, adequado aos novos materiais e recursos construtivos e coerente com o "estado de espírito moderno". Nessa leitura, a arquitetura moderna brasileira não seria então fruto de um "processo de evolução de quatro séculos de arquitetura" mas fruto das "profundas alterações na vida econômica, política, técnica e cultural de São Paulo". ${ }^{66} \mathrm{~A}$ trama apresentada por Ferraz se coloca como oposição ao grupo carioca e a toda a historiografia que se apóia nas diretrizes nesta vertente. Não era novidade, entretanto, a disputa empreendida por Ferraz em relação à primazia da arquitetura moderna no país; desde o final da década de 40 o crítico esteve envolvido em defender Warchavchik e o pioneirismo paulista na célebre polêmica travada com Lucio Costa nos jornais. ${ }^{67}$

63 Idem, ibidem, p.64.

64 Geraldo Ferraz, Warchavchik e a introdução da Nova Arquitetura no Brasil: 1925 a 1940, São Paulo: MASP, 1965.

65 Carlos Martins, op. cit., pp.33-34.

66 Idem, ibidem, pp.33-34.

67 Geraldo Ferraz, "Quem é o pioneiro da arquitetura moderna brasileira? Falta o depoimento de Lúcio Costa", in Diário de S. Paulo, 1/2/1948. Lucio Costa, "Depoimento do arquiteto Lúcio Costa sobre a arquitetura moderna brasileira", in Diário de S. Paulo, $7 / 3 / 1948$. 
A leitura que propõe Flavio Motta em "Introduzione al Brasile" não tem esse caráter de disputa. É, antes, uma tentativa de complexificar um quadro onde até então havia uma única possibilidade de entendimento, e que não havia sido posta em cheque como narrativa. Ele traz outros elementos a serem considerados no panorama geral, e com isso, permite que se reconheçam os acontecimentos, tanto no Rio de Janeiro quanto em São Paulo, como fatos complementares e igualmente relevantes na composição de uma situação geral do país na qual a arquitetura moderna se desenvolve. Flavio Motta não pretende, como Ferraz vinha fazendo desde os anos 1940, declarar um pioneiro, e menos ainda, minimizar a importância do grupo carioca, da presença de Le Corbusier e do projeto do Ministério; por outro lado, enfatiza a relevância das experiências de Warchavchik, Rino Levi e Flavio de Carvalho no campo cultural nacional e sua efetiva contribuição ao estabelecimento da arquitetura moderna no país.

No entanto, só é possível compreendermos o sentido e a importância que adquire cada um desses personagens no quadro composto por Flavio Motta, a medida que entendemos o vínculo que o autor estabelece entre o desenvolvimento arquitetônico e o campo artístico e intelectual. ${ }^{68}$ Motta traça um emaranhado de relações e influências que compõe a esfera cultural do país, dentro do qual cada contribuição adquire sentido no desenvolvimento de um todo orgânico, do qual a arquitetura moderna é parte. Assim, por exemplo, não demonstra nenhum estranhamento no fato de a Semana de Arte Moderna não apresentar uma arquitetura condizente com a postura de renovação que era esperada deste movimento; mas ao contrário, considera que "no terreno da arquitetura as manifestações são mais esporádicas"69, e inclui os manifestos de Warchavchik e Rino Levi, o projeto para o palácio do governo de Flavio de Carvalho, a construção da Casa Modernista num ciclo de desdobramentos da Semana que se estende até 1928, com a publicação de Macunaíma por Mario de Andrade.

Neste mesmo processo de inserção da arquitetura num campo cultural mais amplo, relaciona o florescimento da arquitetura do grupo carioca com um momento de efervescência cultural nacional que se manifestava no Rio de Janeiro após a Revolução de 30:

“O Rio de Janeiro retoma o timão das principais manifestações culturais, atraindo as novas personalidades formadas na região nordeste onde o Manifesto Regionalista de 1926 proclamou novos caminhos para a arte e a ciência. Foi lá no Rio de Janeiro

68 Relação esta que, segundo Carlos Martins, a versão canônica da arquitetura brasileira não conseguiu estabelecer: “ a matriz interpretativa que analisamos não parte do entendimento da arquitetura como parte integrante do campo da produção cultural. Por isso não consegue inserir em sua trama que a arquitetura, apesar de seus condicionantes e procedimentos específicos, tem de enfrentar os mesmos desafios e buscar respostas às mesmas questões que estão colocadas para o conjunto da produção cultural de um momento histórico dado". Carlos Martins, op.cit., p.75.

69 Flavio Motta, op. cit., p.66. Tradução da autora. 
que conquistaram fama os pintores Portinari e Lasar Segall; a música de Villa Lobos; os poemas de Manuel Bandeira e Carlos Drummond de Andrade; a obra literária de Jorge Amado, José Lins do Rego e Graciliano Ramos; a visão sociológica de Gilberto Freyre; a etnografia de Arthur Ramos; a poética de Mario de Andrade. O movimento da arquitetura moderna que tinha apenas esboçado vinha rapidamente delineandose. Em São Paulo já havia se manifestado; e no Rio, as crescentes realizações antiacadêmicas, terminaram por transformar o gosto pelo "neo-colonial" no interesse por uma arquitetura brasileira, "brasileira" não tanto em seus aspectos formais e ornamentais, quanto em seus valores de estrutura, função e outros atributos que pareciam inerentes a tradição arquitetônica. É isto, em grande parte, mérito de Lucio Costa. Sua obra realizou-se na contínua meditação e confronto com os outros vertentes da arquitetura contemporânea. Sob influência de intelectuais como o poeta e musicólogo Mario de Andrade, o escritor Rodrigo de Mello Franco, Carlos Drummond de Andrade e outros, vinham oficialmente acolhidos os novos valores, e isto trouxe o desenvolvimento das mais expressivas e concretas manifestações da arquitetura brasileira contemporânea." 70

Todavia, se por um lado "Introduzione al Brasile" pretende enriquecer a visão estrangeira em seu modo de olhar a arquitetura no Brasil, demonstrando que sua origem, seu desdobramento, sua abrangência no plano cultural são muito mais complexas do que aquelas avaliações recorrentes, por outro lado, esta leitura tem uma finalidade. 0 artigo pretende também fornecer alternativas, resgatar a arquitetura moderna brasileira das críticas negativas que atravessaram a década anterior, principalmente no que dizia respeito a Brasília, que na própria edição da Zodiac, é alvo de duras críticas.

Aproveitando o calor das discussões, a revista traz uma seqüência de artigos específica sobre a cidade recém-inaugurada. 0 primeiro, de Bruno Zevi ${ }^{71}$, traz críticas severas, nos moldes daquelas que havia feito no ano anterior quando esteve presente no Congresso Internacional Extraordinário de Críticos de Arte. Entretanto, Bruno Alfieri, que também esteve presente no Congresso, e que na apresentação dessa seqüência de artigos deixa claro que a posição da revista quanto à Brasília é semelhante a que foi apresentada no Congresso por Zevi ${ }^{72}$, também

70 Idem, ibidem, p. 66. Tradução da autora.

71 Bruno Zevi, "Critica a Brasilia". Zodiac, Milão, n.6, 1960, p.129. Publicado originalmente em "L'architettura" n. 51, 1960.

72 "Poichè la posizione di Zodiac su Brasilia è sostanzialmente vicina a quella di Bruno Zevi, espressa nel suo intervento a Brasilia [...] fu l'único congressista che ebbe il coraggio di afrontare criticamente la nouva capitale, mentre sembrava che i fasti dell'ospitalità del generoso Brasile avessero intimidito e paralizzato l'iniziativa degli altri congressisti italiani, francesi, inglesi e americani." Bruno Alfieri, Zodiac, p.129. 
dá espaço para que os brasileiros "defendam-se", através dos artigos de Oscar Niemeyer e Mario Barata. E o artigo de Flavio Motta, que esteve presente apenas na etapa paulista do Congresso, também tem o sentido de defender a nova cidade.

Logo no parágrafo inicial Motta deixa claro que é somente a partir do conhecimento mais aprofundado das condicionantes históricas e culturais que o artigo pretende apresentar, que será possível, efetivamente, compreender o significado da arquitetura brasileira, sem submetê-la aos "juízos formalistas" ${ }^{73}$; seu artigo pretende reconduzir o julgamento dessa arquitetura, e principalmente da experiência de Brasília, por caminhos que reconheçam seu sentido cultural e político a partir de suas próprias referências.

"Brasília - a obra de Lucio Costa e Oscar Niemeyer - fora de qualquer consideração quanto a sua "funcionalidade" ou não, no futuro, como nova capital do Brasil, como visão introspectiva do país, exemplo de planificação, desejo de unidade nacional, é um dos mais estimulantes fatos culturais e políticos destes últimos anos da República, e que amplia os horizontes da nova geração de arquitetos. Brasília demonstrará quanto seja necessário, na formação do arquiteto, uma consciência política, no sentido mais puro da palavra: isto é, político e civilizador, que acolha os anseios de uma cultura configurada pelas necessidades intimas de um povo. $" 74$

Ao mesmo tempo em que pretende introduzir no debate internacional essas novas possibilidades de olhar, Flavio Motta também quer estabelecer continuidades, "conservar as conquistas qualitativas da arquitetura contemporânea brasileira" ${ }^{75}$, e é nesse sentido que expõe as experiências que apontem para novos caminhos. A principal delas traz o arquiteto Vilanova Artigas como articulador de uma proposta alternativa à arquitetura carioca, que teria seus próprios fundamentos teóricos e expressão plástica diferente daquela difundida internacionalmente como a contribuição brasileira ao modernismo internacional.

Enfatizando esta corrente como uma alternativa socialmente comprometida, Flavio Motta talvez procurasse oferecer à crítica ao formalismo da arquitetura moderna brasileira uma alternativa capaz de ocupar o lugar de destaque que anteriormente havia sido dado ao grupo carioca:

73 "Para falar de arquitetura brasileira sem cair nos costumeiros juízos formalistas, e tentando apontar as novas possibilidades expressivas, é indispensável situar antes algumas rápidas considerações sobre a histórica do país". Flavio Motta, op.cit., p.61. Tradução da autora.

74 Idem, ibidem, p. 67. Tradução da autora.

75 Idem, ibidem, p. 66. Tradução da autora. 
"se quisermos citar ainda um exemplo entre os nomes menos conhecidos da crítica estrangeira, encontramos aquele do arquiteto Vilanova Artigas, que realiza em São Paulo uma intensa atividade doutrinária, seguindo o exemplo de Lucio Costa no que diz respeito às exigências de uma posição teórica. Seja a sua obra o conteúdo irreverente da sua especulação, assume, algumas vezes, um caráter até brutal. Influenciado inicialmente por Frank Lloyd Wright, Artigas não deixou de observar o fenômeno "liberty" no Brasil, e rapidamente intuiu que as premissas modernas deste movimento foram prejudicadas pelas condições sociais e econômicas do país. As suas realizações revelaram o esforço de alcançar novas formas através de processos construtivos independentes da instabilidade da indústria da construção nascente. As suas casas, projetadas para intelectuais e profissionais liberais, são caracterizadas pela economia de recursos da construção, onde, às vezes, o arquiteto se mistura intimamente à atividade do mestre-de-obra e do operário. Hoje, suas realizações vão amadurecendo em direção a um aparente "brutalismo". Deve-se notar que muitas vezes no "brutalismo" a agressividade é denunciada, mas não se expressa como maturidade afetiva e emocional, ou seja, como fator de integração social. Aquilo que esse arquiteto brasileiro procura é a expressão da energia que penetra na matéria com o vigor e a obstinação de quem não impõe limite ao espaço, mas o escava procurando o vazio para o homem. Pensamos que isto é um exemplo que ilustra uma das tendências mais significativas da arquitetura brasileira nesta fase onde a figura do arquiteto se assemelha ao lendário "bandeirante", que abatia a floresta e construía sólidas habitações." 76

Esta associação do grupo de São Paulo ao movimento Brutalista inglês é feita pioneiramente nesta edição da Zodiac, inaugurando uma matriz de leitura que também se tornou recorrente, quando se trata dos desdobramentos da arquitetura moderna ao longo da década de 60.

$\mathrm{O}$ artigo de Flavio Motta introduz o tema, mas é Bruno Alfieri, neste mesmo número, que o desenvolve, apresentando alguns trabalhos de Artigas reunidos sob um ensaio crítico intitulado "João Vilanova Artigas: ricerca brutalista". ${ }^{77}$ Os diálogos possíveis de serem travados entre este ensaio, a introdução de Flavio Motta e as outras leituras que compõem o "Rapporto Brasile" deste número da Zodiac, constituem um importante material para o debate historiográfico acerca da "escola paulista". 
Na década que sucedeu a esta publicação, o movimento "paulista" começou de fato a ocupar um papel de destaque na produção arquitetônica brasileira, gradativamente tomando, em território nacional, o lugar que outrora coubera ao grupo de Lucio Costa no Rio de Janeiro. Os arquitetos em São Paulo, ao mesmo tempo em que desenvolvem projetos dotados de uma série de características próprias - muito ligadas às técnicas construtivas - que os distanciam do modelo consagrado da arquitetura moderna carioca, também passam a comparecer com maior regularidade ao centro dos debates que tomam corpo no plano nacional da década de 60.

Não obstante, no quadro internacional, o mesmo não aconteceu. Apesar da tentativa da Zodiac em apontar caminhos alternativos, que permitissem uma avaliação da continuidade e dos desdobramentos da experiência de Brasília na cultura arquitetônica brasileira e em sua contribuição ao movimento moderno, a crítica internacional pareceu desinteressar-se pelo tema. Uma evidência desse silêncio é, mais uma vez, a quantidade de artigos publicados sobre arquitetura brasileira nas revistas internacionais do período: enquanto no ano de 1960 foram publicados 41 artigos no tema, todos tratando da nova capital que se inaugurava, nos dez anos seguintes foram publicados apenas 54 artigos que tratavam de arquitetura brasileira. E se, no contexto local, o movimento em São Paulo havia ganhado alguma notoriedade em âmbito nacional, no conjunto das publicações internacionais, não é sequer mencionado durante a década de 60; não há entre os artigos publicados qualquer referência a uma "escola" ou formação de uma alternativa à arquitetura carioca.

Prevaleceram, nas leituras estrangeiras, as continuidades consagradas pela historiografia canônica, sacramentadas pelos manuais de arquitetura moderna, contemplando poucos personagens e obras, que de um modo geral, desaparecem do interesse da crítica assim como desaparece a arquitetura moderna brasileira após a conclusão de Brasília. 
Revista Zodiac n.6, especial sobre o Brasil: 1 e 2. capa e contracapa do número,

mostrando a casa de Alvar Aalto e a

sobrecapa que identifica o tema da revista.

3. índice

páginas seguintes

todas as páginas do artigo Rapporto Brasile publicado na edição.
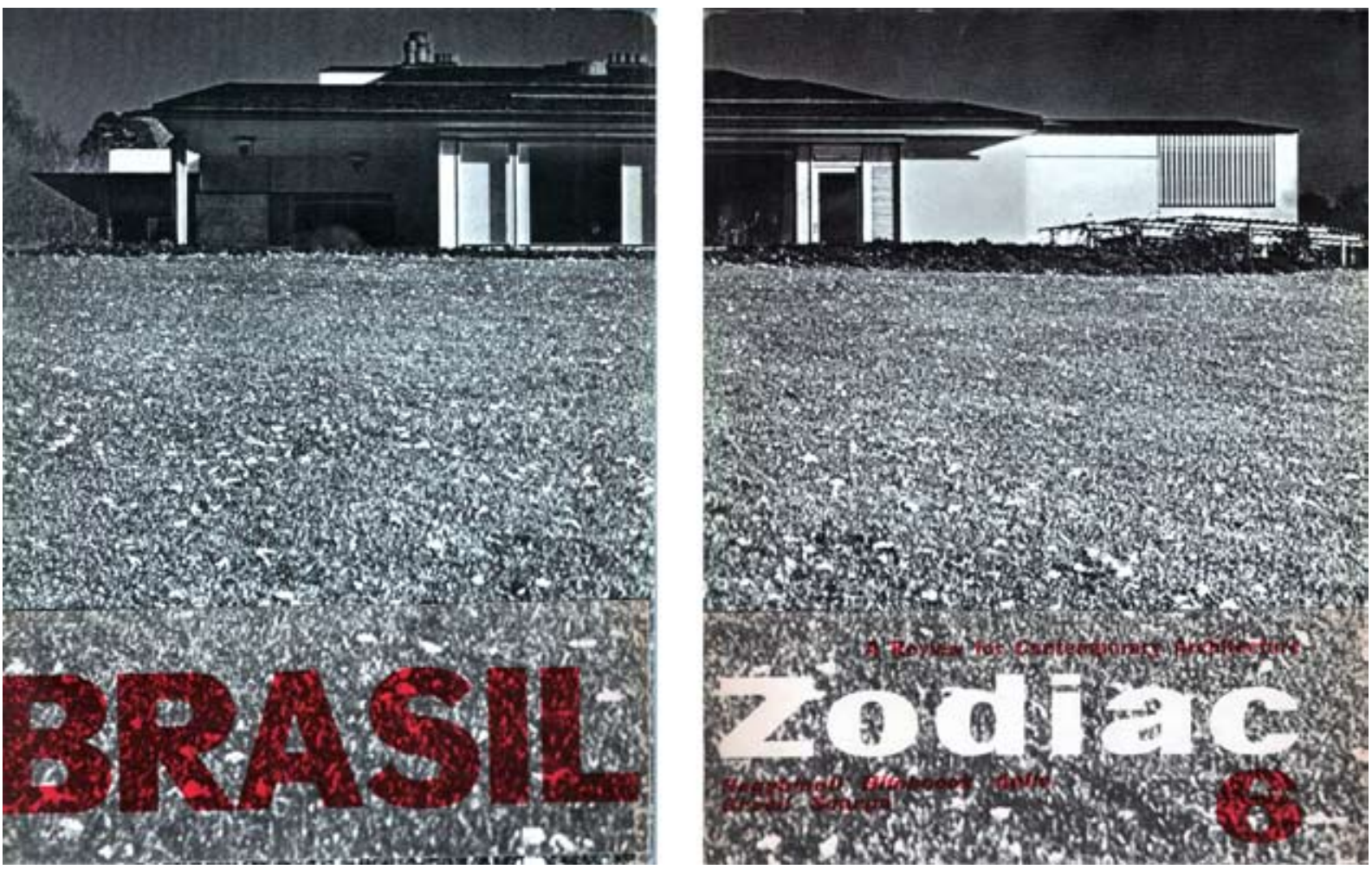


\section{Index}

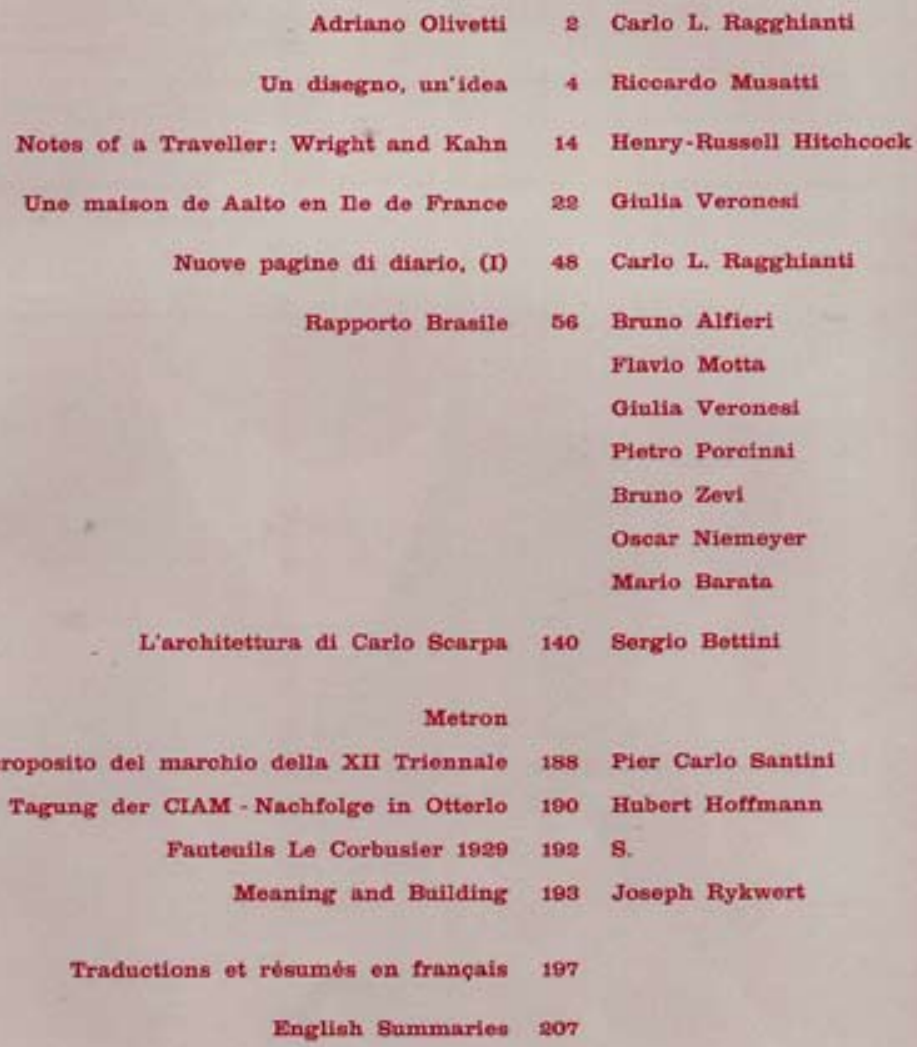



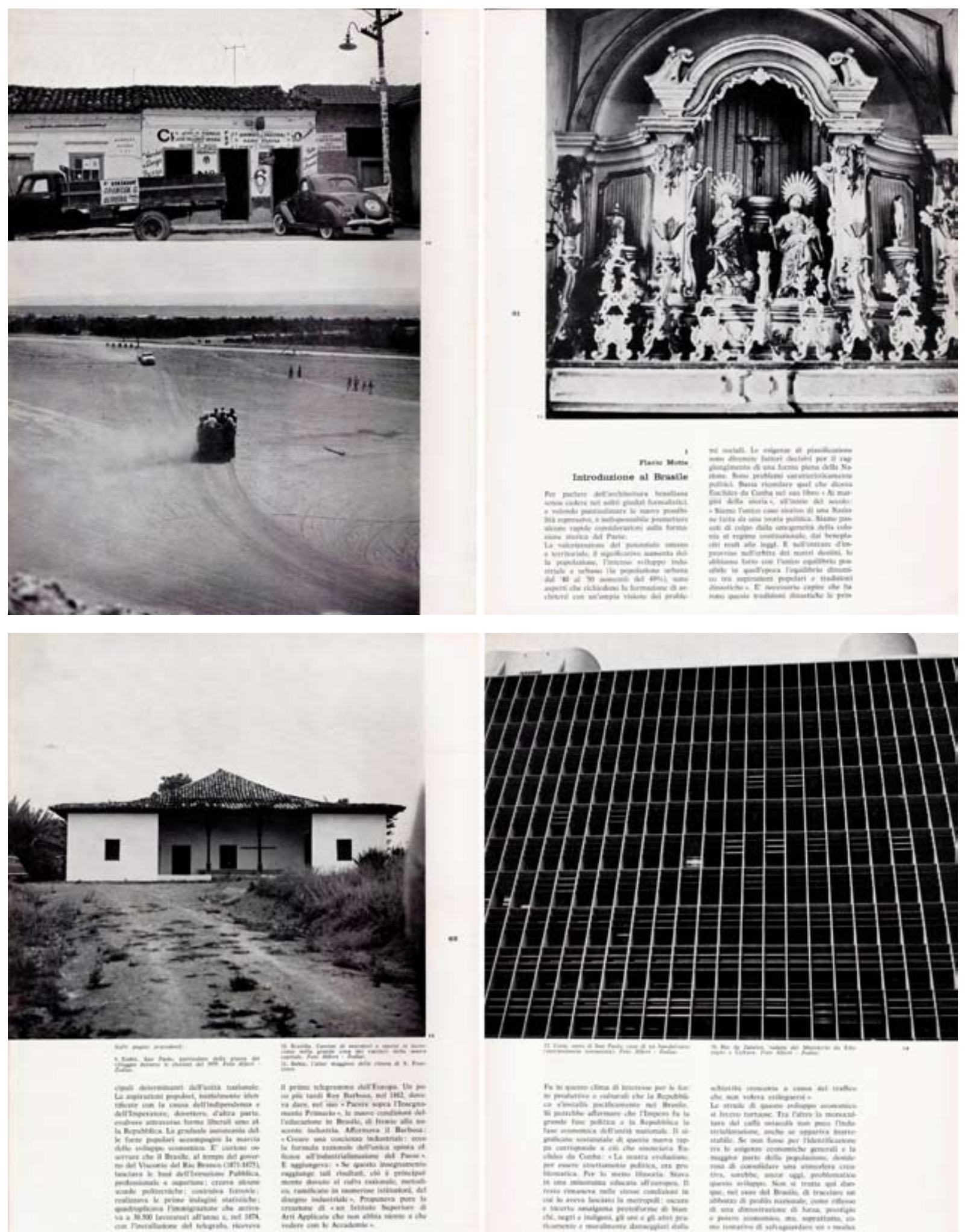

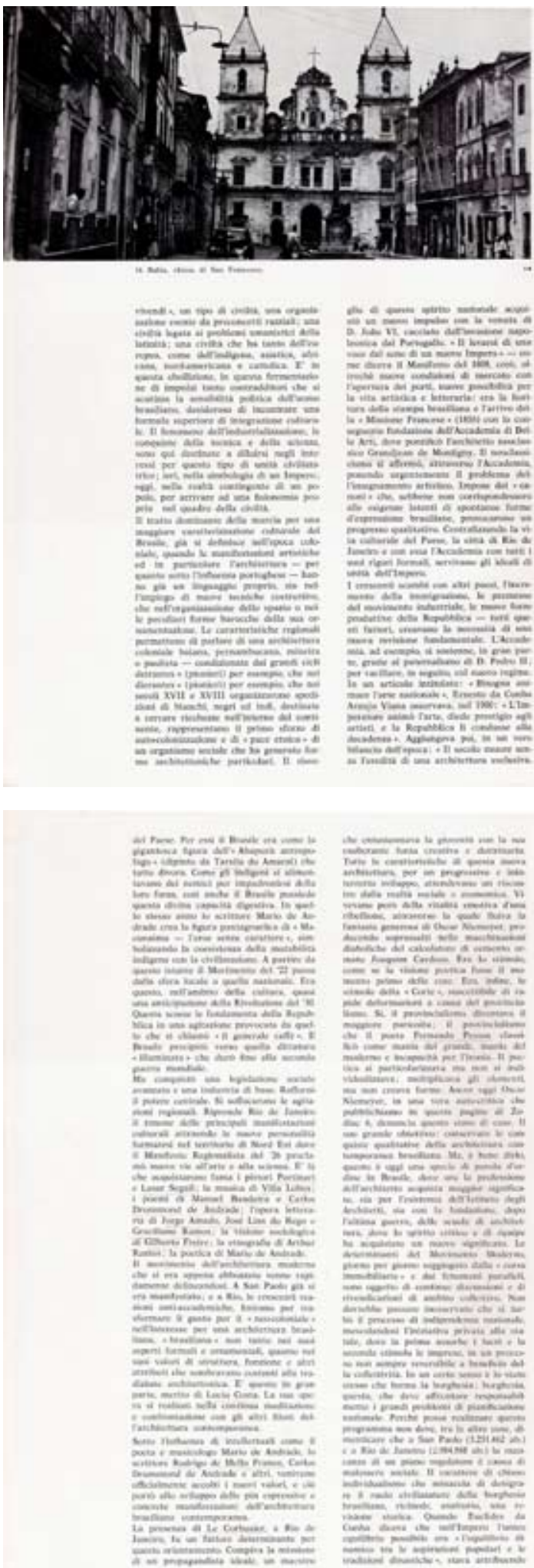
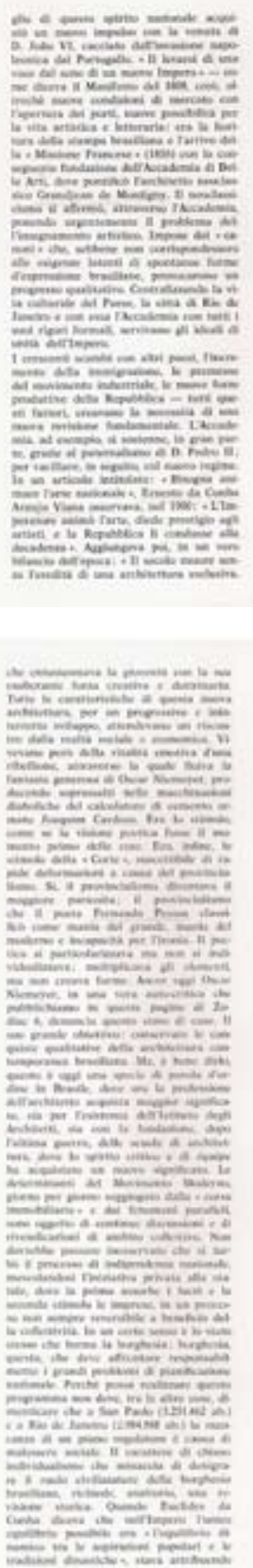
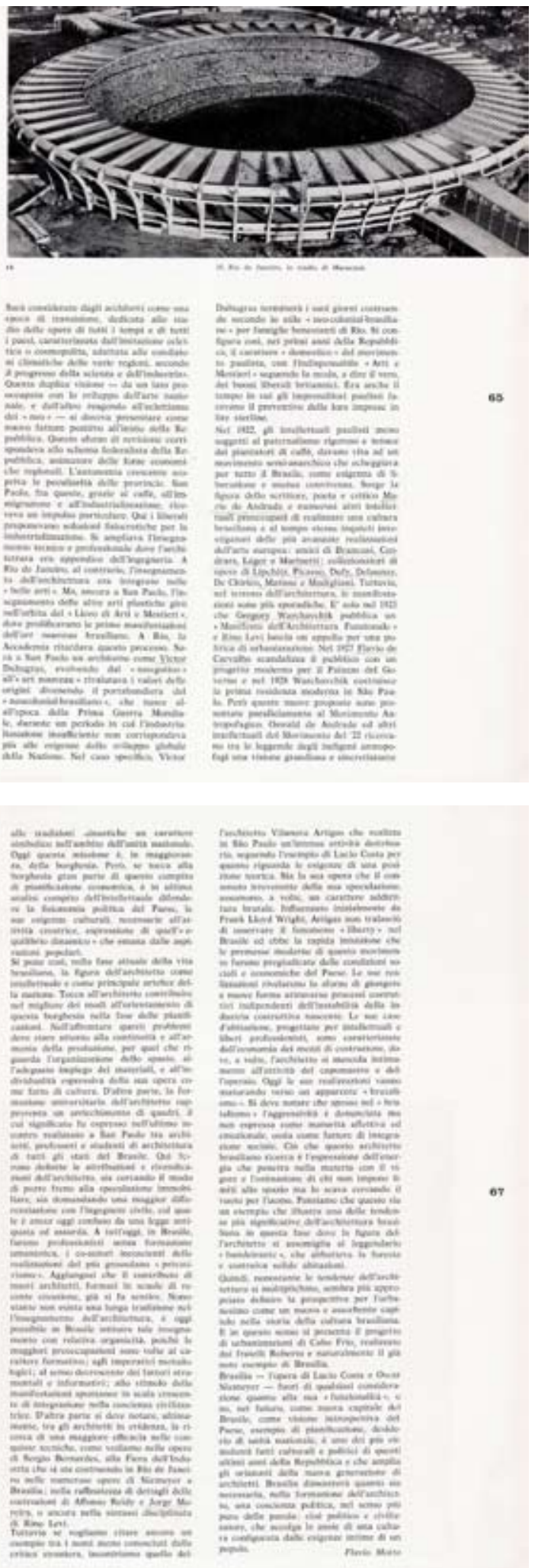



\title{
3. O pavilhão de Osaka, feito até de arquitetura
}

\author{
“Haverá, para alguns, algumas soluções até inexplicáveis, como haverá os que \\ reconhecem que o melhor se apresenta sem explicação. Haverá ainda, por isso, uma \\ arquitetura que inaugura uma 'nova lógica' e que, inclusive, poderá ser feita 'até \\ de arquitetura', ou melhor, de elementos que a arquitetura utilizou para suas novas \\ sínteses, ou 'novas lógicas' espaciais, para não dizer apenas, as novas lógicas do viver \\ que cada obra de arte instaura." 1
}

\subsection{A tradição dos pavilhões brasileiros nas exposições universais}

Com a decisão de participar da Expo70 - como era chamada a exposição de Osaka - seria a $12^{\mathrm{a}}$ vez que o Brasil enviaria representação oficial a uma Exposição Universal². Ainda que nesse momento já não tivessem a mesma importância de suas edições mais celebradas da segunda metade do século XIX, as Exposições Universais ainda mobilizavam um público imenso, e conseguiam manter um certo brilho como grandes vitrines da cultura e do conhecimento acumulados pela humanidade em cada época, e como momento único de representação das nações no cenário mundial.

Como um retrato da modernidade do final do século XIX, as Exposições Universais haviam emergido num mundo onde tomava forma a metrópole moderna, tendo em Paris e Londres sua maior expressão. Não por acaso as duas cidades se revezaram como sede desse acontecimento em suas 4 primeiras edições. Sua função era apresentar panoramas didáticos das conquistas do homem sobre a natureza, servindo aos visitantes como uma "janela para o mundo": ao mesmo tempo em que mostrava as últimas invenções do homem, exibia "o novo,

1 Flavio Motta, “Arquitetura brasileira na Expo-70". Textos Informes, São Paulo, FAUUSP, 1973, p.33.

2 Segundo o trabalho de Andrea Macadar, o Brasil participou oficialmente das seguintes exposições universais: Londres, 1862; Paris, 1867; Viena, 1873; Filadélfia, 1876; Chicago, 1893; Saint Louis, 1904; Bruxelas, 1910; Filadélfia, 1926; Nova York, 1939; São Francisco, 1939; Bruxelas, 1958; Osaka, 1970; Sevilha, 1992; Lisboa, 1998 e Hannover, 2000. Além disso, até a exposição de 1893 o pavilhão do Brasil teve seu projeto elaborado por um arquiteto estrangeiro. [p.16]. Andrea Macadar, Uma trajetória brasileira na arquitetura das exposições universais dos anos 1939-1992. UFRGS, 2005 (Dissertação de mestrado). 
o exótico, o desconhecido, o fantástico e o longínquo"3. Era essa possibilidade de compartilhar o conhecimento que justificava o esforço de encontro das nações, e transparecia já no discurso proferido pelo príncipe inglês Albert, na abertura da primeira Exposição Universal, a de Londres em 18514: "As criações da arte e da indústria não são privilégios de uma nação, pertencem ao mundo inteiro: a Exposição, deve, portanto, ser internacional"5.

Ainda que repleta de nobres intenções, as Exposições Internacionais não deixavam também de ser uma grande feira, que tinham como objetivo imediato a catalogação, troca e venda de produtos. Inseridas na lógica da nova sociedade burguesa moderna em formação, promovendo a comparação entre cultura e desenvolvimento tecnológico das nações, e as pretensões de superioridade, o poder e a supremacia de algumas nações sobre outras. Enquanto tal, em contraponto à vida moderna e à civilização industrial e urbana, elas também se dedicavam a reiterar a idéia de 'paraísos' terrestres, onde matas virgens, povos folclóricos e culturas primitivas aludiam à natureza selvagem ainda por ser descoberta. Desse modo, enquanto não conseguiam competir na demonstração de pujança econômica, as nações menos desenvolvidas - como o Brasil - apareciam freqüentemente como espelho do exótico. Segundo Sandra Pesavento, o Pavilhão Brasileiro na Exposição de Paris de 1889 estava

"mais para o paraíso terrestre, exótico, luxuriante e, porque não dizer, implicitamente sensual, do que para uma nação moderna, industrial e progressista. [...] Sem dúvida alguma, o Brasil representava a consagração do 'exotique': nação-continente, liberal, simpático e esclarecido."6

A Primeira Guerra Mundial representou um momento de ruptura na ênfase ao caráter industrial e comercial das Exposições que vinham sendo realizadas até aquele momento, em função das transformações impostas pela Guerra, da diminuição do poder de difusão das Exposições e de uma certa relativização da crença na ideologia do progresso. As Exposições realizadas após a Guerra assistiram a um abrandamento tanto de sua apologia ao desenvolvimento através da indústria, quanto de seus "anseios universalistas"7. Ainda que continuassem a ser mostradas as conquistas industriais, essa tendência não é mais o

3 Sandra Pesavento, Exposições universais: espetáculos da moderninade no século XIX. São Paulo: Hucitec, 1997, p. 45.

4 Segundo Sandra Pesavento, o nome oficial da exposição de Londres era "The great Exibition of the works of Industry of All Nations". op. cit., p,48.

5 discurso de abertura da Exposição de Londres, in Fabiano Scherer, Expondo os planos: as exposições universais do século XX e seus planos urbanísticos. UFRGS, 2002 (Dissertação de mestrado), p.12.

6 Sandra Pesavento, op. cit., p.137.

7 Fabiano Scherer, op.cit., p.55. 
tema predominante nas Exposições, sendo gradativamente enfatizada uma vocação para as diversões, tendência que vinha se desenvolvendo já desde a exposição de Paris em 1867.

Se nas suas primeiras versões os propósitos da realização de uma Exposição Universal tinham contornos eminentemente econômicos, após a Primeira Guerra, e a medida em que adentravam o século $\mathrm{XX}$, transformavam-se gradativamente em eventos mais voltados à informação e ao desejo de conhecer novos lugares e se fazer reconhecer entre eles, assumindo um caráter "lúdico", mais próximo do parque de diversões do que da feira de negócios:

"Espaço de lazer, a exposição ofereceu às mercadorias e à produção técnica que Ihes deram nascimento o aspecto lúdico capaz de atrair multidões. Não é por nada que o imaginário social conservou justamente esta faceta de tais eventos: as exposições como espetáculo, onde operários e burgueses contemplam as maravilhas da indústria e da civilização. Lugar artificialmente criado, evento efêmero, as exposições têm de festa este caráter de curta duração e brilho. Grandes construções foram feitas para não durar e mesmo a Torre Eiffel, símbolo da exposição de 1889, não tinha em seu início a pretensão da perenidade. Como festa, a exposição celebra com fausto e encantamento a sociedade industrial e glória da ciência. Buscando na própria ciência aplicada à técnica e nos avanços da indústria os recursos para os seus engenhos de diversão, a festa complementa a fábrica, assim como o ensino é suplantado pelo lazer"8.

Nesse sentido, a arquitetura dos pavilhões expositivos não apenas viria a inaugurar um programa funcional novo, mas atenderia às necessidades simbólicas da exposição, a tal ponto que muitas vezes a própria arquitetura passaria a se confundir com os objetivos principais de cada exposição. Cada vez mais, a medida em que as exposições ganhavam importância, o pavilhão não era visto somente como um abrigo para os produtos que iria mostrar, mas ele se tornava o produto em si, e a sua característica de construção efêmera abria possibilidades de experimentação formal e construtiva capazes de projetá-lo em meio aos demais.

Os dois Pavilhões brasileiros que atraíram a atenção internacional nas Exposições o fizeram justamente através de seu projeto arquitetônico peculiar. De fato, no século XX, ainda que projetados como estruturas temporárias, alguns dos pavilhões construídos para as Exposições Universais tornaram-se obras emblemáticas da arquitetura moderna, dos debates em curso, e ainda representaram momentos singulares na carreira de alguns de seus autores, como é o caso dos Pavilhões L'Esprit Nouveau (Paris, 1925) e Philips / Le Poème Électronique

8 idem, ibidem, p.50. 
(Bruxelas, 1958) de Le Corbusier, o Pavilhão Alemão de Mies van der Rohe (Barcelona, 1929), o Pavilhão dos EUA de Buckminster Fuller (Montreal, 1967) e também dos pavilhões brasileiros de Sérgio Bernandes (Bruxelas, 1958) e Oscar Niemeyer e Lúcio Costa (Nova York, 1939).

O Pavilhão de Nova York, além disso, tem o sentido de um marco na arquitetura moderna brasileira, pois foi efetivamente após sua construção que as atenções internacionais voltaram-se à produção do país, e mais especificamente, a vertente carioca. Objeto de concurso nacional realizado ao final de 1937, o próprio edital exigia que o Pavilhão fosse necessariamente expressão da arquitetura contemporânea ${ }^{9}$, e além disso, o julgamento considerou como critério principal de avaliação o "caráter nacional" do edifício ${ }^{10}$ dentro da linguagem contemporânea, de certo modo antecipando a discussão que se desencadearia com maior força a partir da publicação do catálogo Brazil Builds, acerca da contribuição própria da arquitetura brasileira ao movimento internacional. A tentativa de representar uma característica nacional através do projeto do Pavilhão não era uma novidade, pois as participações do Brasil com pavilhão próprio nas exposições anteriores a de Nova York haviam sido também pautadas por uma discussão de uma arquitetura com características nacionais: tanto o da Exposição da Filadélfia, em 1925, quanto a de Sevilha, em 1928, haviam sido construídos no estilo neocolonial. Na Feira de Nova York, a exigência do edital do concurso pela "arquitetura contemporânea" como possibilidade de representação nacional era um sinal de que, após a experiência do Ministério da Educação que se encontrava em construção, o governo brasileiro definitivamente abraçaria a arquitetura moderna como expressão nacional, demonstrando que era fortuita a associação desta com a idéia de modernização e progresso. Além disso, o próprio tema da Feira, "O mundo de amanhã", induzia construções mais de acordo com as tendências contemporâneas, e a organização da Feira, através de uma "junta de arquitetura" que regulava as construções dos pavilhões, desaconselhava "a construção de réplicas e estruturas extremamente convencionais em termos de estilo"11.

A participação brasileira despertava tanto os interesses da "política de boa vizinhança" do governo de Roosevelt, quanto as aspirações comerciais do Brasil. 0 interesse mútuo na participação brasileira podia ser medido através da localização privilegiada do sítio destinado

9 Segundo Bruand, o edital recomendava que o pavilhão brasileiro correspondesse ao programa geral da Exposição, que pretendia "oferecer uma visão do "mundo de amanhã", que era o tema da Exposição. Yves Bruand, Arquitetura Contemporânea no Brasil. São Paulo, Perspectiva, 1997, p.105.

10 Bruand, op.cit., p.105, segundo publicação da revista $A \cup$ n.2, 1938, que tratava do concurso.

11 Segundo Carlos E. Dias Comas. Precisões brasileiras: sobre um estado passado na arquitetura e urbanismo modernos a partir dos projetos e obras de Lucio Costa, Oscar Niemeyer, MMM Roberto, Affonso Reidy, Jorge Moreira \& Cia, 19361945. Paris: Universidade de Paris VIII, 2002. (Tese de doutorado), p.177. 
ao Pavilhão do Brasil no plano da Exposição, e também através do empenho brasileiro em se destacar frente aos outros países da América do Sul. Segundo Carlos Eduardo Comas, a comissão designada para organizar o concurso elaborou um extenso programa para o pavilhão, no qual

"galerias de exposição, auditório, bar-restaurante com pista de dança e palco para música ao vivo, café, escritório do Comissário Geral e jardim devem destacar a unidade, originalidade e dinamismo da cultura brasileira, assim como as riquezas agrícolas e minerais, bases da qualificação exportadora do país. A afirmação idiossincrática de cultura e paisagem deve chamar a atenção para os seus atrativos turísticos, enquanto a afirmação duma modernização em curso deve chamara atenção para as oportunidades de negócio, deixando claro que não se tratava de mais uma republiqueta latino-americana. "12

Certamente o projeto construído atendia a estas aspirações. Elaborado em conjunto por Lucio Costa e Oscar Niemeyer, primeiro e segundo colocados no concurso, foi amplamente elogiado pela crítica internacional, despertando o interesse internacional pela arquitetura brasileira que sucedeu nas décadas seguintes.

O outro pavilhão brasileiro, para a Exposição Internacional de Bruxelas em 1958, projetado por Sergio Bernardes, embora muito menos divulgado, foi oficialmente premiado com a "Estrela de Ouro" durante a Exposição. Seu projeto não foi objeto de concurso, mas sim encomendado a Sérgio Bernardes em função da boa repercussão que causou seu pavilhão projetado para a exposição do IV Centenário de São Paulo sobre o lago do Ibirapuera ${ }^{13} \mathrm{e}$ como parte de um contrato de projeto de quatro pavilhões em estrutura metálica. O lote destinado ao Brasil na Expo de Bruxelas era bastante precário se comparado ao de Nova York: bastante inclinado, escondido pelo pavilhão mexicano e distante das áreas mais centrais da Exposição ${ }^{14}$. 0 projeto se organizava a partir de uma rampa circular em torno de um jardim central, o projeto do pavilhão tirava partido da inclinação do terreno, sob uma única cobertura leve e inclinada, suspensa sobre pilares de aço que se encontravam do lado externo do pavilhão. Apesar do prêmio recebido, a repercussão do pavilhão de Bruxelas na imprensa foi pequena. Aliado à pouca divulgação, o fato de não ter sido realizado um concurso para a

12 Idem, ibidem, p.172.

13 Trata-se do Pavilhão da CSN. A respeito da produção de Sérgio Bernardes no período, ver Ana Luísa Nobre, op. cit., capítulo 04.

14 Andrea Macadar, op. cit. p.67. 
sua realização - que certamente provoca maior mobilização e divulgação dos projetos - tornou escassos os registros acerca do projeto do Pavilhão de Bruxelas, ainda hoje pouco estudado.

\subsection{A Expo 70 e o concurso para o Pavilhão do Brasil}

A cidade de Osaka foi escolhida como sede daquela que seria a primeira (e até o momento, a única) Exposição Universal na Ásia, e reservou para o evento uma área de 330 hectares, a maior área que uma Exposição ocupara até então. 0 Japão pretendia transformar a Expo70 num evento grandioso, que marcasse seu lugar no mapa internacional do desenvolvimento, antecipando a posição que o país viria a atingir na década seguinte, após um crescimento econômico vertiginoso apoiado num modelo de exportações.

0 arquiteto japonês Kenzo Tange foi então escolhido como chefe da equipe que elaboraria o plano geral da exposição. Para o projeto, selecionou 12 arquitetos locais que colaborariam no plano geral e posteriormente, assumiriam cada um o projeto de um edifício específico inserido neste plano. A equipe organizou a área da exposição a partir de um sistema que teria como elemento principal um eixo de infra-estruturas que foi denominado como "Trunk Facilities", seguindo um conceito que estabelecia diferentes hierarquias de uso do espaço a partir deste "tronco de serviços". Segundo o arquiteto, a estrutura básica do plano era mesmo a de uma árvore, onde o tronco concentraria as principais funções técnicas e simbólicas da feira e seu acesso principal. Era uma "artéria de tráfego" que organizava o percurso de todos os visitantes e as nações representadas; e que concentrava restaurantes, serviços, informações, sanitários, lojas. A partir dele, distribuíam-se estruturas de transporte de pedestres como se fossem "galhos", que conduziam os visitantes aos pavilhões, que segundo Tange, seriam finalmente "os frutos" dessa árvore. ${ }^{15}$ Todo esse esforço era uma tentativa de disciplinar a diversidade inevitável em um evento dessa natureza, que o arquiteto considerava problemática. A proposta era conseguir mostrar que havia uma unidade que organizava e dava sentido àquele conjunto de pavilhões tão variado. E justamente para não competir com a exuberância dos pavilhões, a equipe propunha que essa estrutura principal fosse a mais "neutra" possível, amparando-se na discrição para que os pavilhões fossem os elementos de destaque.

15 Segundo depoimento de Kenzo Tange sobre o plano da Expo, publicado na revista JA - Japan Architecture, n. 4-151, abril, 1969, p.18. 


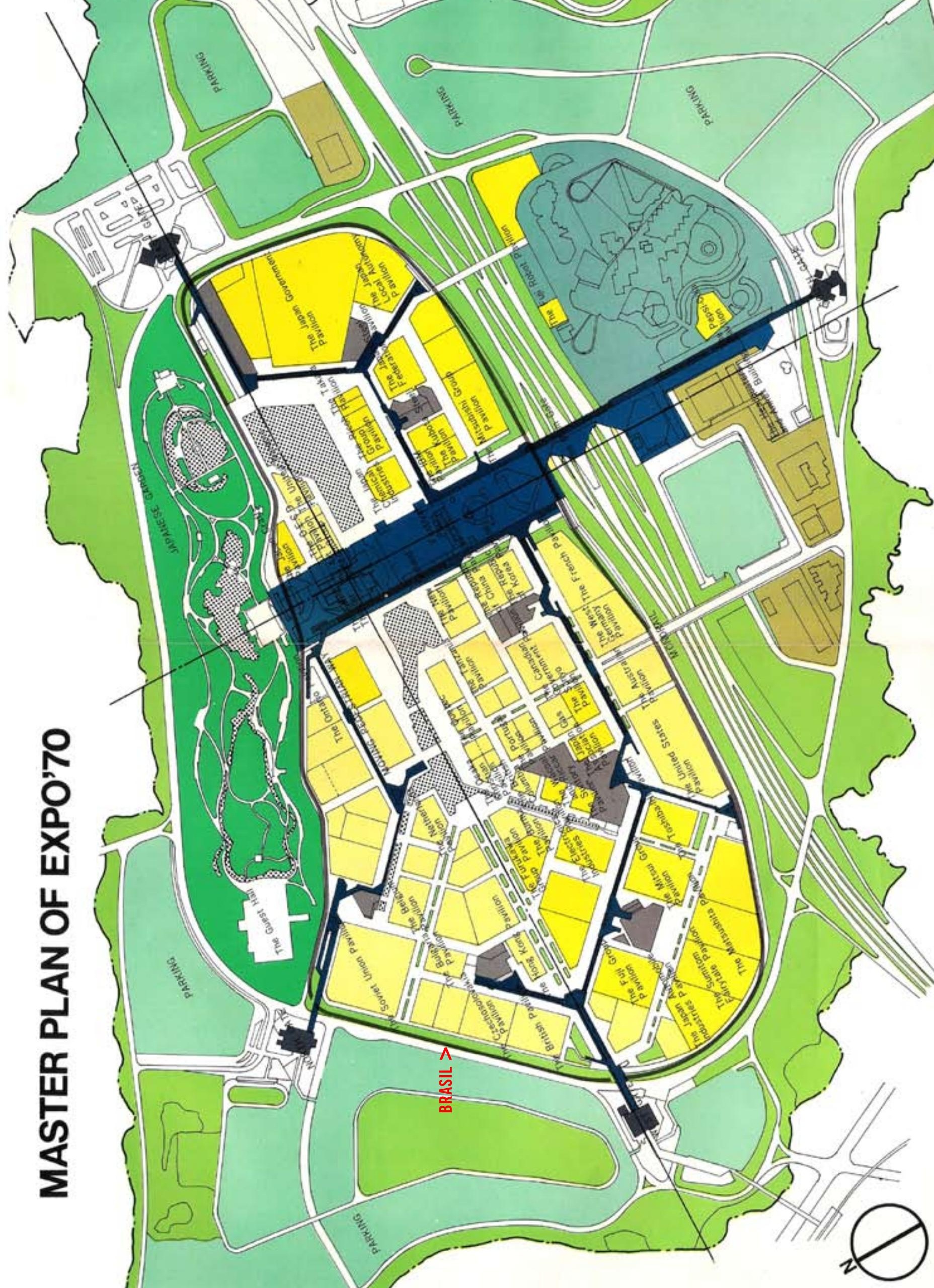


Como sistema de circulação de pedestres, espalhados pela Expo, a proposta era a implantação de longos trechos de esteiras-rolantes elevadas, contidas numa estrutura tubular, que partindo do "tronco" principal, percorriam grande parte da área da exposição e desembarcavam seus passageiros em pequenos núcleos de infra-estrutura [como se fossem pequenas estações] de onde se poderia circular por um conjunto de pavilhões.

Os principais edifícios da Expo70 estavam concentrados numa área inscrita no "tronco", denominada "Symbol Zone", uma faixa de 150m de largura que percorria 1000m de extensão, e dividia todo o sítio da Expo em duas zonas principais, norte e sul: na porção norte estavam localizados os pavilhões internacionais, e no sul, os pavilhões de recreação, administração e empresas e serviços locais. Este núcleo, uma grande praça coberta que acolhia os visitantes na sua chegada, também se destinava a ser o local de expressão do tema geral da Expo: "Progress and Harmony for Mankind", explorado numa grande exposição. 0 elemento principal desta praça era a cobertura, uma estrutura metálica em forma de uma treliça espacial, de aproximadamente 300x100m com um vazio circular em um dos trechos, por onde emergia a Torre do Sol, uma enorme figura de braços abertos que tomava o centro da praça de chegada e saudava os visitantes como uma "divindade" das "festividades do passado". Segundo depoimento de Paulo Mendes da Rocha à autora, a cobertura foi montada no chão, e içada inteira para que pousasse sobre os pilares, numa operação tecnicamente difícil e muito demorada [a cada dia a cobertura subia alguns centímetros apenas]. Como um contraponto a este enorme plano horizontal, Tange projetou uma torre, "the landmark tower", com um sentido de observatório, que utilizava exatamente o mesmo sistema estrutural - e mantendo as mesmas dimensões estruturais - da cobertura.

Com suas esteiras rolantes elevadas, espalhadas por toda a área como tentáculos da enorme estrutura da entrada, a Expo70 parecia aspirar a um futuro espelhado na ficçãocientífica, projetando uma imagem de progresso tecnológico adequada ao momento internacional, em que a corrida espacial, a automação e o desenvolvimento frenético das telecomunicações eram os temas do momento.

A exposição de Osaka, com toda sua exuberância tecnológica, foi também considerada como a última das grandes exposições desse gênero. Para Andrea Macadar, desde que haviam adentrado o século XX, as Exposições Universais já não conseguiam mais obter os êxitos daquelas que marcaram o século XIX, e gradativamente foram perdendo seu sentido, de modo que as últimas Exposições realmente grandiosas teriam sido as de Bruxelas (1958), Montreal (1967) e Osaka. Segundo ela, a evolução dos meios de comunicação de massa que se deu pouco tempo depois da feira de Osaka proporcionou a oportunidade de exibição e intercâmbio em qualquer momento e lugar, transformando radicalmente e experiência da visita física a 

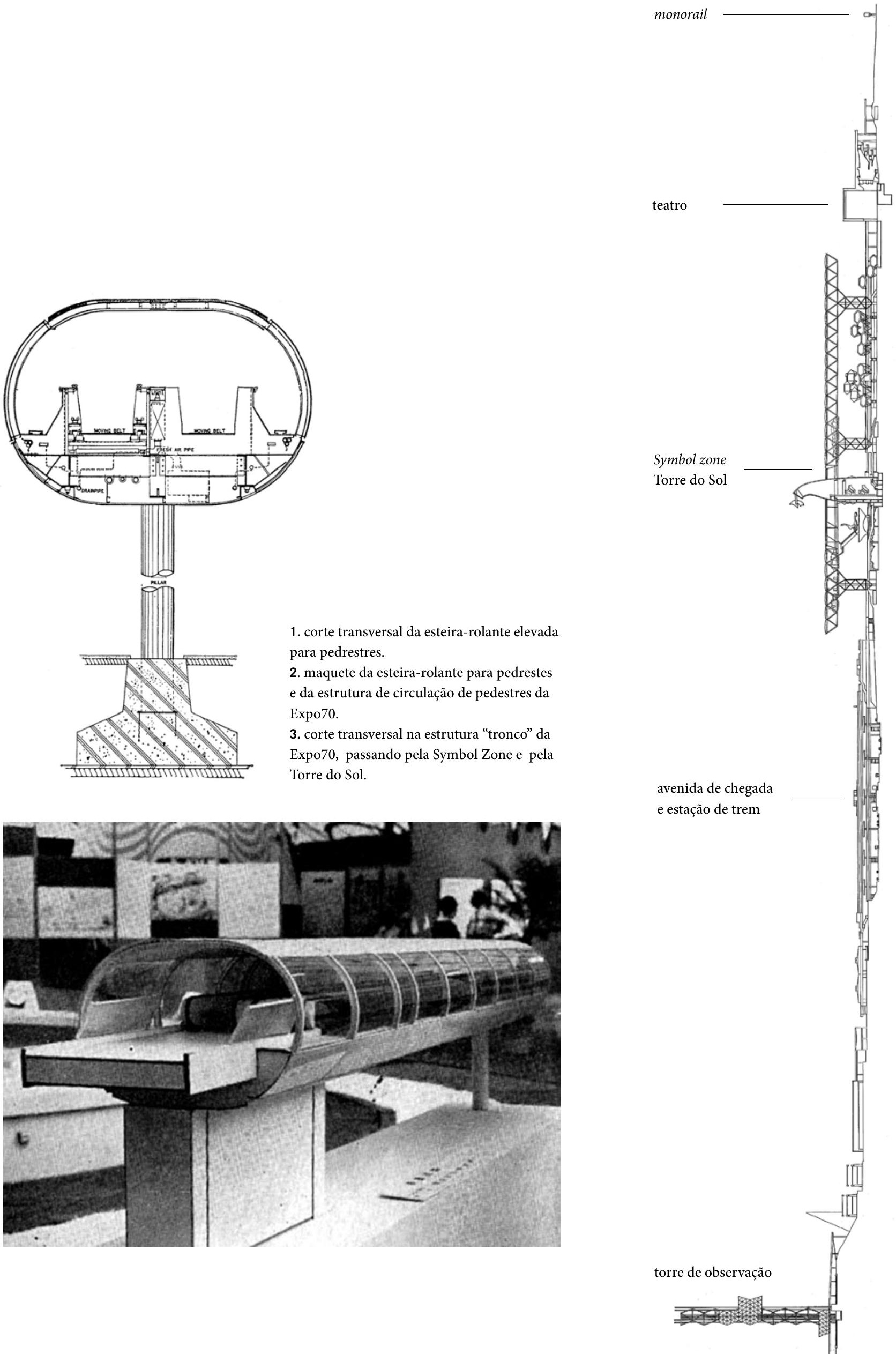

1. corte transversal da esteira-rolante elevada para pedrestres.

2. maquete da esteira-rolante para pedrestes e da estrutura de circulação de pedestres da Expo70.

3. corte transversal na estrutura "tronco" da Expo70, passando pela Symbol Zone e pela Torre do Sol.

avenida de chegad e estação de trem

torre de observação 

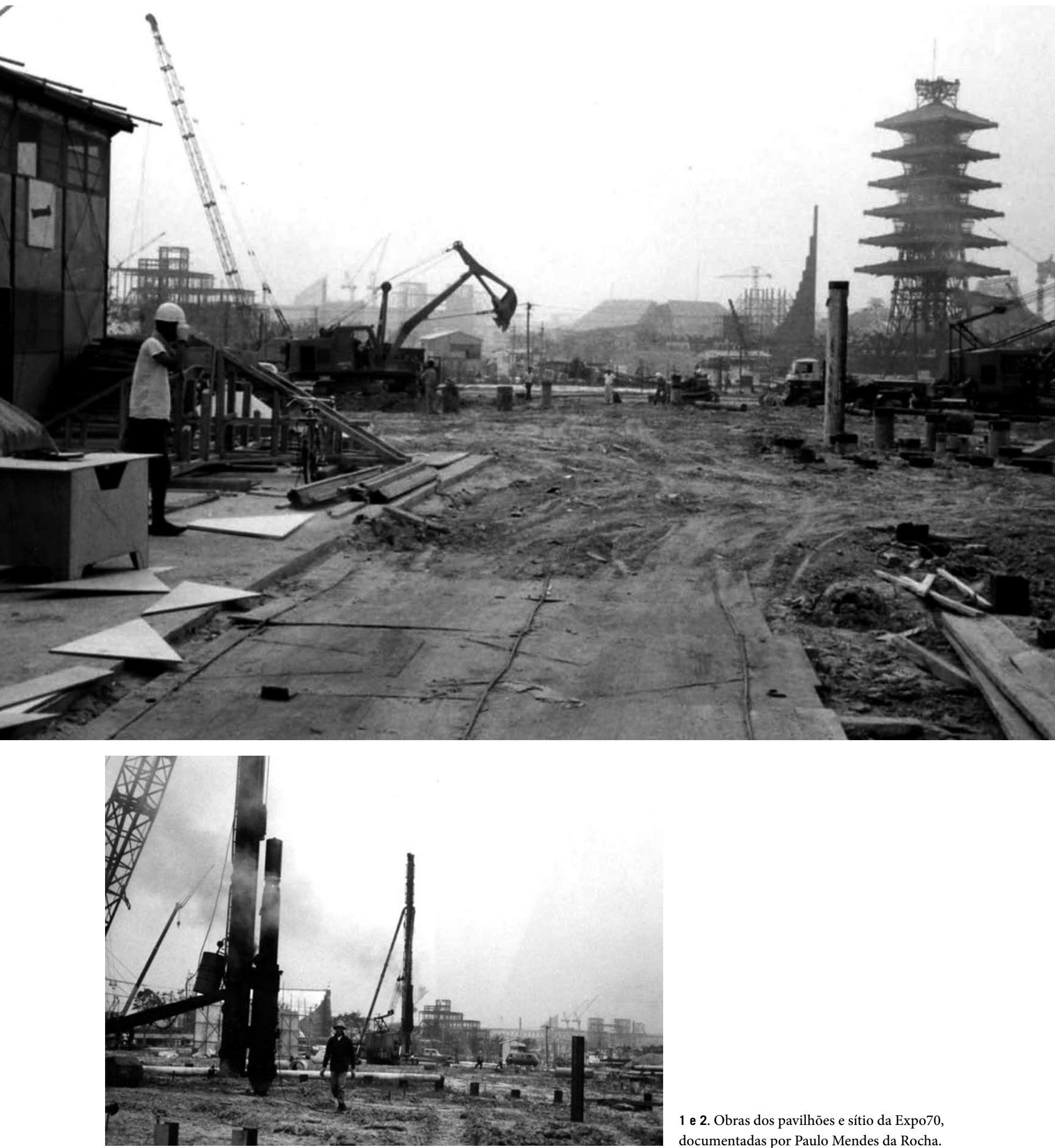

1 e 2. Obras dos pavilhões e sítio da Expo70, documentadas por Paulo Mendes da Rocha. 
eventos desse tipo, mais do que nunca, em ocasiões de promoção de cidades, deslocando o interesse da comercialização de produtos e intercâmbio de tecnologia. ${ }^{16}$

A revista JA de abril de 6917 publicou um número especial sobre a Expo70, constituindo o mais completo dos registros que as revistas de arquitetura fizeram sobre o evento. Nessa edição, publicada ao mesmo tempo em que o Brasil realizava seu concurso do Pavilhão, pode-se ver que as obras na Expo e em muitos dos pavilhões estrangeiros já se encontravam adiantadas; as imagens publicadas na revista trazem a maquete do sítio já com diversos dos pavilhões implantados. A edição traz também o projeto de 27 pavilhões internacionais, além do todos os projetos "domésticos". Podemos perceber entre todos esses projetos um predomínio absoluto das construções com estruturas espaciais, treliças metálicas, estruturas geodésicas e uma enorme utilização dos materiais plásticos e sintéticos, seja na construção de pavilhões inteiros a partir de estruturas infláveis, seja como elemento de revestimento.

A Expo70 foi finalmente inaugurada em 15 de março de 1970, e permaneceu aberta até 13 de setembro. Dela participaram 76 países e sua média de visitação foi de 350 mil pessoas por dia, totalizando um público de nada menos que 64 milhões de visitantes, um recorde para as exposições internacionais realizadas até aquele ano.

No conjunto geral da exposição, o lote destinado ao Brasil se encontrava num dos extremos da área norte, exatamente na fronteira do terreno da exposição com uma grande área de estacionamento. Uma das frentes era voltada para uma avenida próxima a uma das "estações de desembarque" de pedestres, e o outro lado voltado para uma via de circulação de automóveis e para os trilhos do monorail que circulava em volta de todo o sítio.

\section{o concurso para o pavilhão brasileiro}

A possibilidade de participação brasileira na feira de Osaka causou enorme expectativa ${ }^{18}$ entre os arquitetos, muito em função da "tradição" da arquitetura moderna brasileira nas exposições internacionais através dos dois pavilhões anteriores. O Brasil estava ausente das exposições internacionais desde a participação da Exposição de Bruxelas em 1958, na Expo de Bruxelas. Apesar do bem-sucedido projeto de 1958, o país não havia enviado representação para as seis feiras seguintes ${ }^{19}$.

16 Andrea Macadar, op. cit., p.29. Depois de Osaka, só foi realizada uma outra Exposição Universal em 1986, em Vancouver. A esse respeito, ver também Fabiano Scherer, op. cit., p. 38.

17 JA - Japan Architecture, op. cit.

18 Segundo descreve o editorial da Revista Acropole, n. 359, março, 1969.

19 Cf. Macadar, as Exposições realizadas entre a de 1958 e a de 1970 foram: 1962 - Seattle; 1964 e 1965 - Nova York; 1967 - Montreal; 1968 - San Antonio [USA]. 


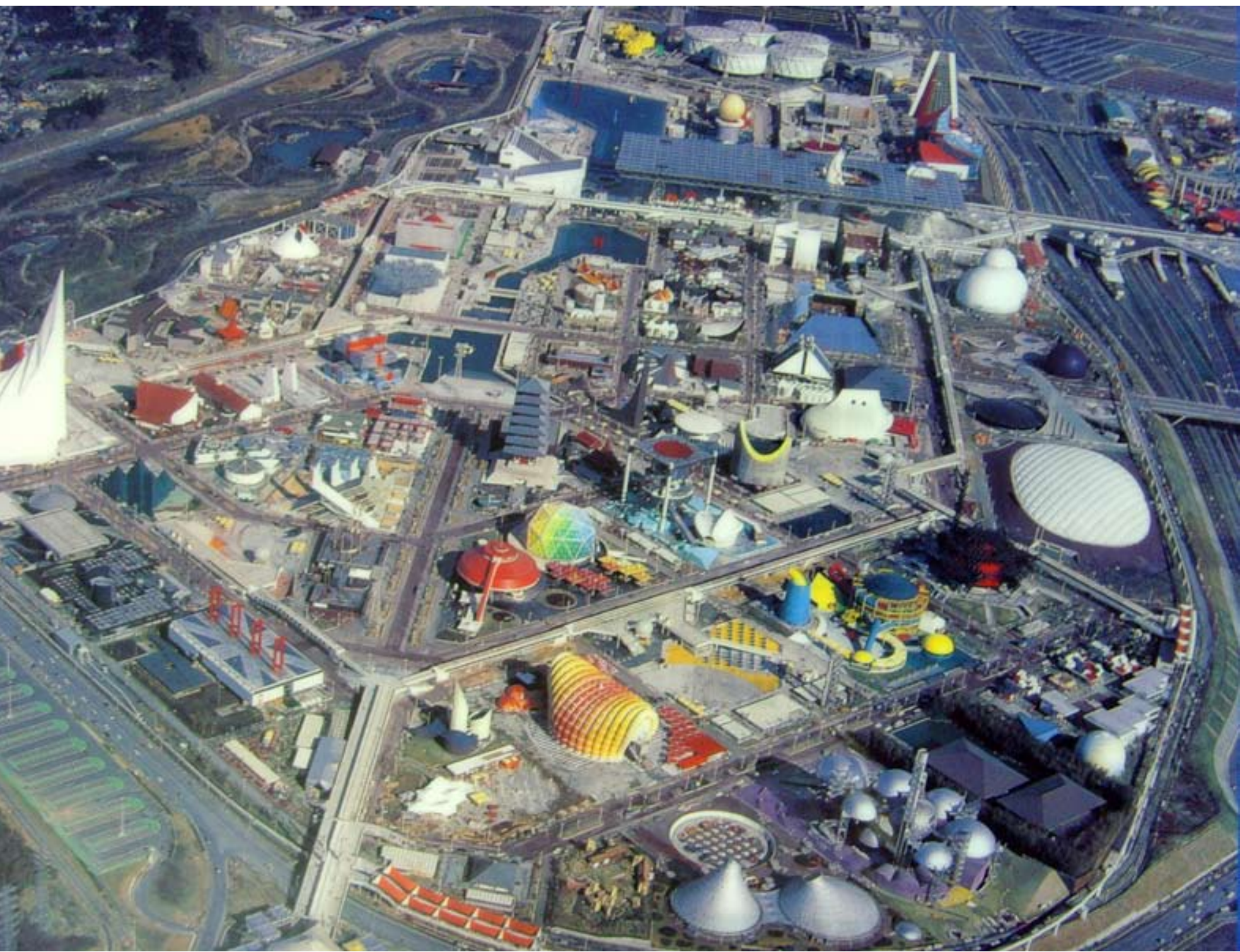

1. vista aérea da Expo70, na qual é possível perceber a diversidade de tipologias e materiais utilizados na construção dos pavilhões, própria do período de exacerbação da tecnologia. Na parte superior está a Symbol Zone e o pavilhão Japonês; à esquerda, na borda da imagem, está o Pavilhão do Brasil.

2. na página ao lado, mapa souvenir da Expo70, indicando a localização do Pavilhão do Brasil, entre o Hawaí e a Checoeslováquia, próximos ao pavilhão da União Soviética. 

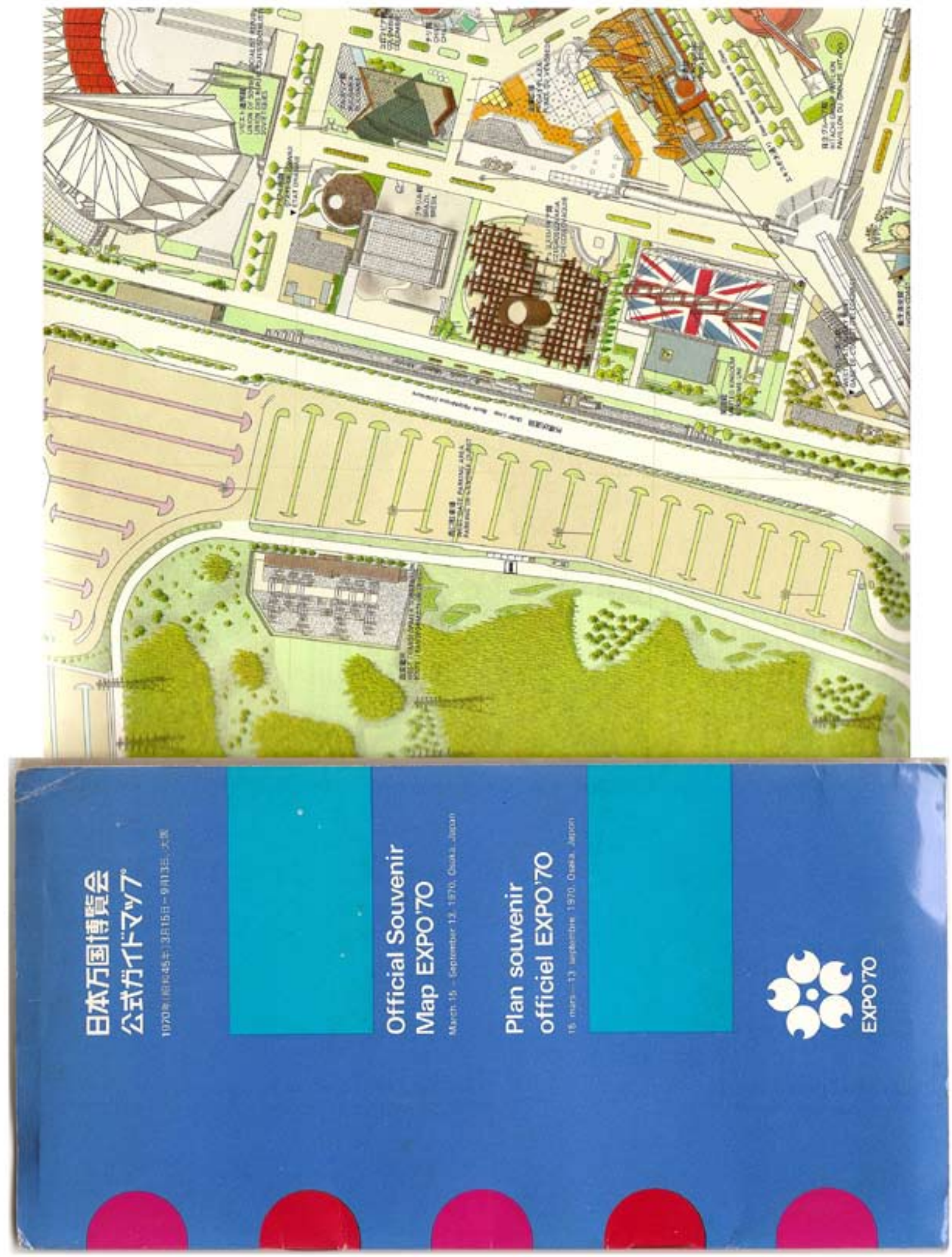
O governo brasileiro havia decidido participar do concurso já bastante em cima da hora. A revista Acrópole anuncia na edição de março de 69 que o Itamaraty havia dado início às tramitações para a participação na Expo, ao mesmo tempo em que algumas revistas internacionais já estavam publicando os projetos de pavilhões que participariam da feira nas edições dos últimos meses de 68. Na edição de abril de 1969, a Acrópole anuncia os projetos premiados, e na edição seguinte, publica na capa a imagem do primeiro colocado e apresenta com mais detalhes todos os projetos premiados. Nessa edição, elucida alguns dos trâmites ocorridos na definição do concurso e seus procedimentos. Segundo a revista, o Ministério das relações Exteriores, em resposta a um convite feito pelo primeiro ministro japonês ao presidente Costa e Silva, havia nomeado uma comissão que deveria organizar a participação brasileira, composta por três membros: Fabio Yassuda, que era o presidente da Cooperativa Agrícola de Cotia, foi nomeado comissário da coordenação brasileira em Osaka; José Eugênio Macedo Soares, o vice-comissário, era parte da equipe do Ministério da Indústria e Comércio e por fim um secretário, Alfredo Grieco. Yassuda, alguns meses depois do concurso, foi nomeado Ministro da Indústria e Comércio pelo presidente Médici. Yassuda relata em entrevista que, na época do concurso, vinha freqüentando muito o Itamaraty, em função do firmamento de acordos internacionais de comércio exterior. É possível, assim, compreendermos que o interesse do governo militar brasileiro, ao participar de uma Exposição Universal naquele momento é também comercial, a ponto de nomear um "comerciante" para presidir a comissão. Nesse sentido, um Pavilhão que pudesse se destacar entre todos aqueles da Expo poderia ser um bom atrativo de negócios.

A comissão teria então solicitado ao presidente do IAB - Eduardo Kneese de Mello - a indicação de 5 nomes de arquitetos que estivessem aptos a realizar o projeto do pavilhão, proposta à qual o IAB negou e se dispôs a organizar o concurso, ainda que houvesse pouco tempo hábil para isso. 0 concurso foi então divulgado com o prazo de 25 dias para a apresentação das propostas. 0 edital foi elaborado pelo arquiteto nomeado assessor do concurso, Mauricio Schneider, juntamente com o presidente do IAB e o arquiteto Fabio Penteado. Segundo a revista, foram entregues 83 projetos, a maior participação em concursos de âmbito nacional até aquele momento ${ }^{20}$.

A grande mobilização dos profissionais para participar do concurso do Pavilhão de Osaka tinha também relação com o fato de que, praticamente uma década depois da inauguração de Brasília, este era o primeiro concurso público de arquitetura realizado desde aquele que

20 Conforme levantamento publicado na revista Acropole, entre os 83 projetos entregues, participaram arquitetos de 9 estados, sendo 39 do estado de São Paulo, 16 do estado da Guanabara, 7 do Paraná, 7 do Ceará, 6 de Minas Gerais, 5 da Bahia, 4 do Rio Grande do Sul, 3 de Brasília e 2 de Pernambuco. Acropole n.360, p.11, abril, 1969. 
havia definido o projeto da nova capital, o que certamente atraía muitos interssados. No entanto, o momento desse segundo concurso não lembrava em nada aquele no qual havia se realizado o primeiro. Pode-se dizer que a década que separa a inauguração de Brasília do Pavilhão de Osaka foi marcada por profundas transformações em todos os campos, e muito especificamente no campo cultural brasileiro.

No célebre ensaio “Cultura e política, 1964-69", publicado em 1960, Roberto Schwarz nos apresenta um início de década pautado por uma movimentação cultural intensa, na qual as mais diversas formas de expressão passaram por um momento de frutífera inquietação, estimuladas por um pensamento de esquerda que apostava no progresso e nos avanços tecnológicos e econômicos anunciados a partir de meados dos anos $50^{21}$.

Segundo Schwarz, em seus primeiros anos no poder, o governo militar manteve-se numa situação de certa "aceitação" frente à "presença cultural de esquerda", num período imediatamente posterior ao golpe. As iniciativas culturais orientadas por um pensamento de esquerda se mantinham em um círculo relativamente fechado, concentradas "nos grupos diretamente ligados à produção ideológica, tais como estudantes, artistas, jornalistas, parte dos sociólogos e economistas, etc. - mas daí não sai, nem pode sair por razões policiais"22. Enquanto se mantinha presa em seus próprios círculos, a intelectualidade de esquerda era "poupada" pela ditadura. A medida que este isolamento não significava uma ameaça ao sistema instaurado, a produção teórica e artística pôde até mesmo "florescer" naquele momento, num movimento crescente que, segundo ele, teria durado até 1968. Com o Al-5, o reconhecimento da existência da guerrilha revolucionária, o fechamento do Congresso Nacional e a extinção dos direitos políticos dos cidadãos, fazem com que as prisões, a tortura, a censura e a repressão, até então mais restritas aos sindicatos e as ligas camponesas, comecem a atingir diretamente não somente os artistas e intelectuais, mas também a própria classe média.

Se até aquele momento, os militares não sentiam a necessidade de demonstrar "seu esforço ideológico, pois dispondo da força dispensavam a sustentação popular"23, a partir do momento em que se encrudelece, o regime precisa também fortalecer certas imagens. Nesse sentido, traz consigo a "esfera ideológica", que se traduz "na profusão de bandeiras nacionais, folhetos de propaganda, a instituição de cursos de ginástica e civismo para universitários"24, e também outras imagens que reforcem esse caráter. Assim, a decisão do governo militar de levar um Pavilhão Brasileiro a uma Feira Internacional necessariamente sediando uma mostra 
informativa sobre o país, doze anos após a última participação brasileira nesses eventos, é em parte motivada por esse conjunto de intenções de sentido ideológico que permeia a situação nacional naquele momento.

Nesse sentido, a intervenção do IAB nesse processo e sua tomada de frente na organização do concurso significaram uma certa autonomia na escolha do projeto que representaria o Brasil, que possibilitava um debate fora do âmbito direto dos interesses ideológicos governamentais. Esta independência da organização do concurso talvez seja uma das razões para se entender, por exemplo, a contradição entre o fato de Paulo Mendes da Rocha ter vencido o concurso do Pavilhão e ter sido cassado na mesma semana da divulgação do resultado ${ }^{25}$. No entanto, se o projeto arquitetônico do Pavilhão de Paulo Mendes da Rocha conseguiu se manter à parte de um interesse ideológico mais direto, o mesmo não se pode dizer da mostra informativa apresentada no Pavilhão ${ }^{26}$, projetada por Flavio Motta e preterida por outra na qual prevalecia a ênfase na propaganda nacionalista.

A comissão julgadora do concurso era composta pelos arquitetos Pedro Paulo de Mello Saraiva, Henrique Mindlin, Miguel Pereira e Giancarlo Gasperini, e o engenheiro Macedo Soares, que compunha a comissão organizadora da participação brasileira na Expo. Os trabalhos foram expostos e julgados no edifício do MAM do Rio de Janeiro.

Apenas um pequeno trecho da ata do júri foi publicado na revista Acropole juntamente com os projetos premiados, e trata-se do único trecho conhecido deste documento ${ }^{27}$. Nele, a comissão julgadora deixa claro que não interessava ao pavilhão brasileiro a "ênfase sobre o lado tecnológico", já que não era objetivo da representação nacional tentar se igualar aos "países desenvolvidos", e afirma que muitos dos projetos concorrentes "se deixaram levar pelos aspectos técnicos", de modo que a comissão julgadora descartou de início os trabalhos que davam ênfase à tecnologia. A ata se encerra então com a seguinte consideração: havia sido "fácil destacar o primeiro prêmio dentro das premissas que foram estabelecidas", ao contrário das outras classificações que foram consideradas muito difíceis ${ }^{28}$.

25 Segundo depoimento de Paulo Mendes da Rocha a autora, sua cassação e o resultado do concurso foram publicados quase que simultaneamente.

26 A mostra será discutida mais detalhadamente no item 3.4.

27 Durante a realização deste trabalho, entramos em contato com alguns dos arquitetos que participaram do concurso à procura, entre outras coisas, do edital e da ata da comissão julgadora, no entanto, nenhum deles possui esses documentos. Ao mesmo tempo, realizamos uma consulta por escrito com o mesmo propósito ao arquivo do Itamaraty em Brasília, que no entanto não possui nenhum registro do concurso de arquitetura; os únicos documentos que constam neste arquivo a respeito da Expo são, segundo o setor responsável, alguns ofícios que tratam do envio de objetos e materiais para Osaka na ocasião da Expo. Outra tentativa foi feita através do Itamaraty, que solicitou à Embaixada do Japão em Brasília que envie ao arquivo qualquer documentação que constar em seus arquivos em Brasília sobre a participação brasileira na Expo 70, no entanto, esta solicitação também não obteve resposta positiva.

28 Acropole n.361, maio, 1969, pp.13-27. 
A edição da Acropole apresenta sucintamente todos os outros 7 projetos premiados ${ }^{29}$. Pretendemos aqui apenas apresentar uma visão geral do escopo do concurso, na tentativa de melhor compreender as razões que levaram o júri a escolher o pavilhão que é nosso objeto de estudo, para isso, apresentamos uma breve descrição dos outros projetos, com base no que foi publicado pela Acrópole.

Nesta coletânea é possível notar que alguns dos projetos, como partido, apresentaram soluções muito próximas ao vencedor: uma única cobertura sob a qual estavam distribuídas todas as atividades, reproduzindo uma idéia que, naquele momento, já poderia ser considerada um partido recorrente. Grande parte dos projetos que vinham sendo realizados pelo grupo de arquitetos articulado em torno de Vilanova Artigas, por exemplo, mantinham a organização dos programas sob uma única cobertura desde o início da década de 60 , como é o caso do próprio edifício da FAUUSP, projetado por Artigas em 1961. Nesse sentido, o partido da única cobertura apareceu como solução recorrente entre os premiados do concurso, facilitado ainda mais pelo caráter mais livre do programa de um pavilhão de exposições.

É o caso, por exemplo, do $2^{\circ}$ colocado, de autoria de Koiti Yamaguchi, Luigi Villaveccia, e Rogério Dorsa, que propõe uma cobertura plana quadrada, apoiada sobre 8 pilares periféricos, constituída por tubos metálicos soldados tangencialmente de modo a formar uma grelha. 0 terreno é ocupado por uma série de patamares e taludes de desenho irregular, num contraponto à malha rígida da cobertura, que vão definindo recintos específicos para cada atividade. Pendentes da cobertura, alguns mezaninos comportam a área de exposição e o Itamaraty. 0 memorial do projeto apresenta uma longa explicação sobre a solução estrutural e o método construtivo, numa provável tentativa de explorar um caráter mais "tecnológico" da solução, que se aproximasse dos debates internacionais que cercavam a Expo70. Esta idéia de um pavilhão mais tecnológico também é enfatizada pelo proposta da utilização de diversos painéis com projeções audiovisuais pendurados por todo o espaço sob a cobertura ${ }^{30}$.

A outra equipe de paulistas, coordenada por Francisco Petrarcco, uma das cinco que foram classificadas em $4^{\circ}$ lugar, também apresenta uma proposta que tem como partido a organização sob uma única laje de cobertura. Neste caso, tratava-se de uma grelha de concreto de 40X40m, composta por módulos em abóbodas de dimensões variadas, apoiada sobre 4 pilares, e do mesmo modo, abrigando um térreo livre pelo qual se distribui o

29 Além da equipe de Paulo Mendes da Rocha, as outras equipes premiadas tinham a seguinte composição: $2^{\circ}$ Iugar - Koiti Yamaguchi, Luigi Villaveccia, Rogério Dorsa e Walter Caprera, de São Paulo; $3^{\circ}$ Iugar - José Sanchotene, Alfredo Willer e Oscar Mueller, do Paraná; em $4^{\circ}$ Iugar, foram premiadas 5 equipes: Flavio Mindlin Guimarães, Marken Landa e Roberto Loeb, de São Paulo; Francisco Petrarco, Edgar Dente, Ana Maria de Biase, Maria Helena Flynn e Miguel Juliano, de São Paulo; Sigbert Zanetini, de São Paulo; Marcos Flaksman e Wolfgan Reiber, do Rio de Janeiro.

30 "Pavilhão de Osaka - $2^{\circ}$ prêmio". Acropole n.361, maio, 1969, pp.18-20. 

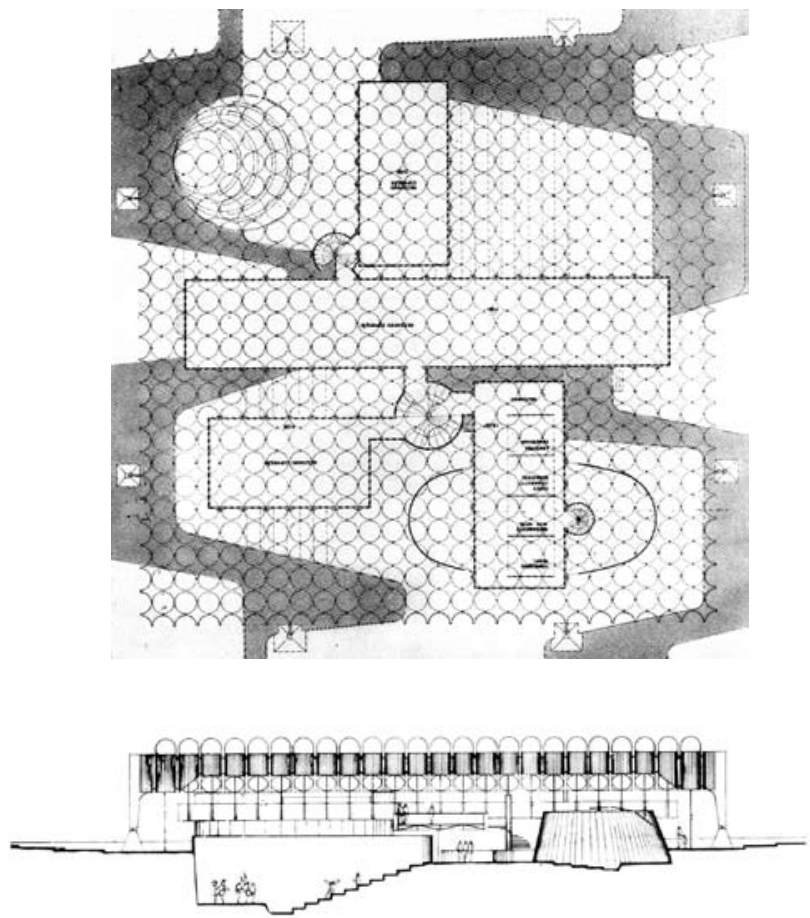

1 e 2. Segundo prêmio: Koiti Yamaguchi, Luigi Villaveccia, e Rogério Dorsa / planta do nível térreo e corte transversal
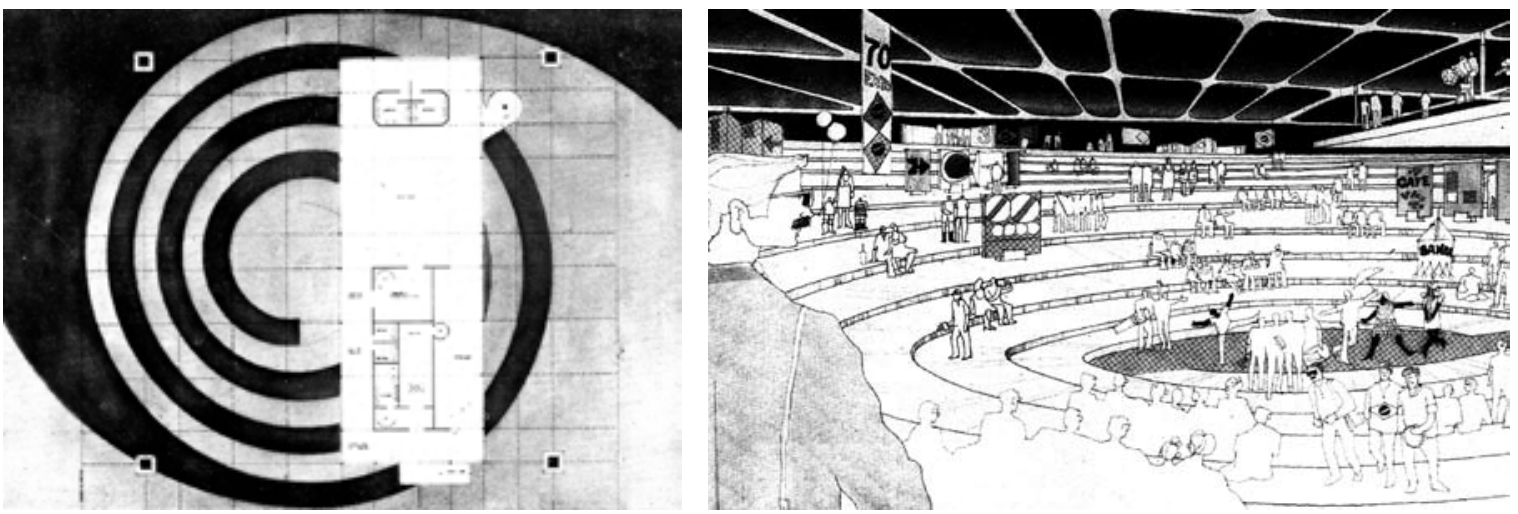

1 e 2. Quarto prêmio: Francisco Petrarcco / perspectiva interna e planta do nível térreo 
programa ${ }^{31}$. Neste térreo, todas as atividades públicas estavam previstas para serem realizadas num anfiteatro em espiral, que ocuparia toda a área sob a cobertura, enquanto um mezanino regular, suspenso por tirantes da cobertura, abrigaria alguns serviços como o Itamaraty.

Ao mesmo tempo em que as equipes de São Paulo se mantém em seu partido recerrente, uma equipe do Paraná, de José Sanchotene, Alfredo Willer e Oscar Mueller, classificada em $3^{\circ}$ lugar, é das poucas a contrariá-lo; ao contrário, sua proposta se baseia numa "sucessão de espaços crescentes em área e volume, ligados entre si"32, numa distribuição em espiral, dividia em vários níveis, articuladas em torno de um núcleo de circulação vertical. Fechado em si mesmo, segundo o memorial, o projeto busca um "efeito visual" no meio de tantos outros pavilhões, além de definir um percurso rígido na circulação dos visitantes e apresentação da mostra expositiva, que recorria à separação da circulação de entrada e saída do pavilhão. Nesta proposta também há uma ênfase na concepção estrutural como a possibilidade de expressar "tecnologia", conhecimento técnico, e na "eficiência" do edifício, que, ainda segundo o memorial descritivo, funcionaria como uma máquina, respondendo aos propósitos de um pavilhão de apresentação do país.

Já a equipe de Flavio Mindlin Guimarães, de São Paulo, uma das classificadas em $4^{\circ}$ lugar, optou por conceituar sua proposta na idéia de um pavilhão desmontável, claramente voltado a uma função temporária ${ }^{33}$. Para isso, propõe a utilização de um sistema tubos e braçadeiras convencionalmente aplicados na montagem de andaimes e escoramentos, sugerindo que fossem alugados diretamente no Japão. 0 partido propõe uma área abrigada sob uma única cobertura de plástico transparente, delimitada em todo o seu perímetro pela estrutura tubular, e organizada internamente através de diferentes níveis conectados por rampas. Há também neste projeto a idéia de um percurso definido a ser percorrido pelo visitante.

O projeto da equipe coordenada por Sigbert Zanetini, de São Paulo, também classificado em $4^{\circ}$ lugar, opta por uma apresentação inusitada: divide os usos do edifício em "impactos", que correspondem cada um a uma ação - assistir, participar, viver e levar. A cada uma delas, uma planta esquemática localizando aquele uso no edifício e uma breve descrição ${ }^{34}$. Desse modo, os registros do projeto apresentados na revista (e possivelmente o material entregue ao concurso), não são exatamente precisos na definição de soluções técnicas, materiais,

\footnotetext{
"Pavilhão de Osaka - 4 prêmio". Acropole n.361, maio, 1969, p.24.

"Pavilhão de Osaka - $3^{\circ}$ prêmio". Acropole n.361, maio, 1969, p.21.

"Pavilhão de Osaka - $4^{\circ}$ prêmio". Acropole n.361, maio, 1969, p.23.

34 "Pavilhão de Osaka - $4^{\circ}$ prêmio". Acropole n.361, maio, 1969, p.25. Trataremos particularmente dessas descrições e dos usos propostos por cada um dos premiados para o espaço do pavilhão, no último item desse capítulo, na discussão sobre a exposição.
} 

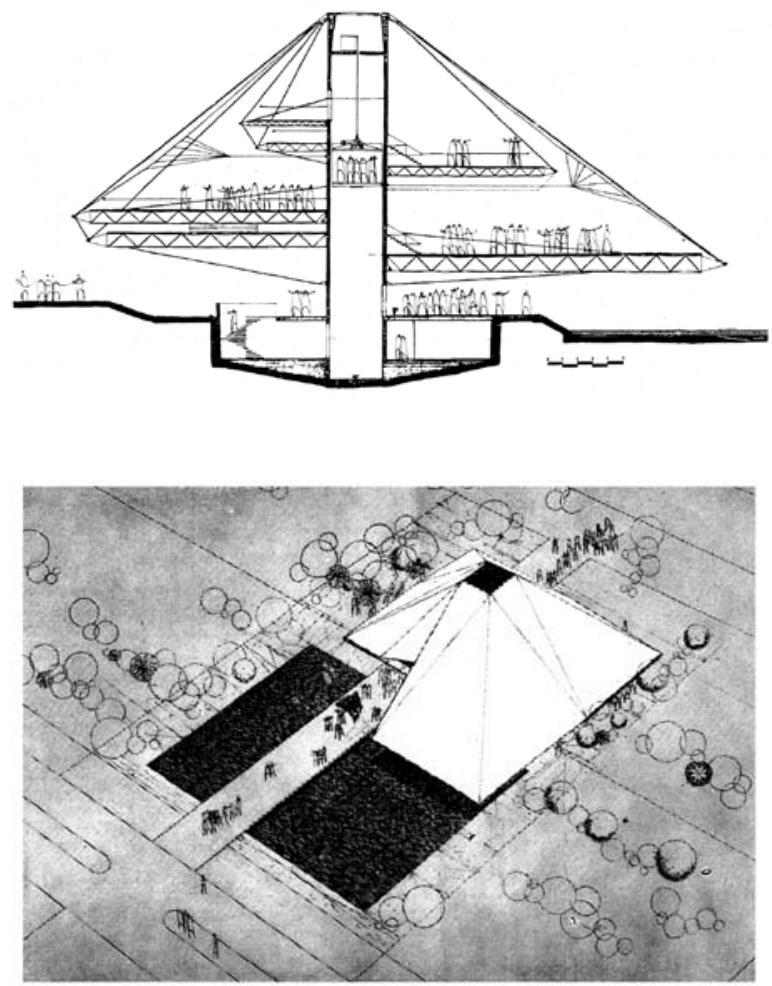

1 e 2. Terceiro prêmio: José Sanchotene, Alfredo Willer e Oscar Mueller / corte transversal e perspectiva externa
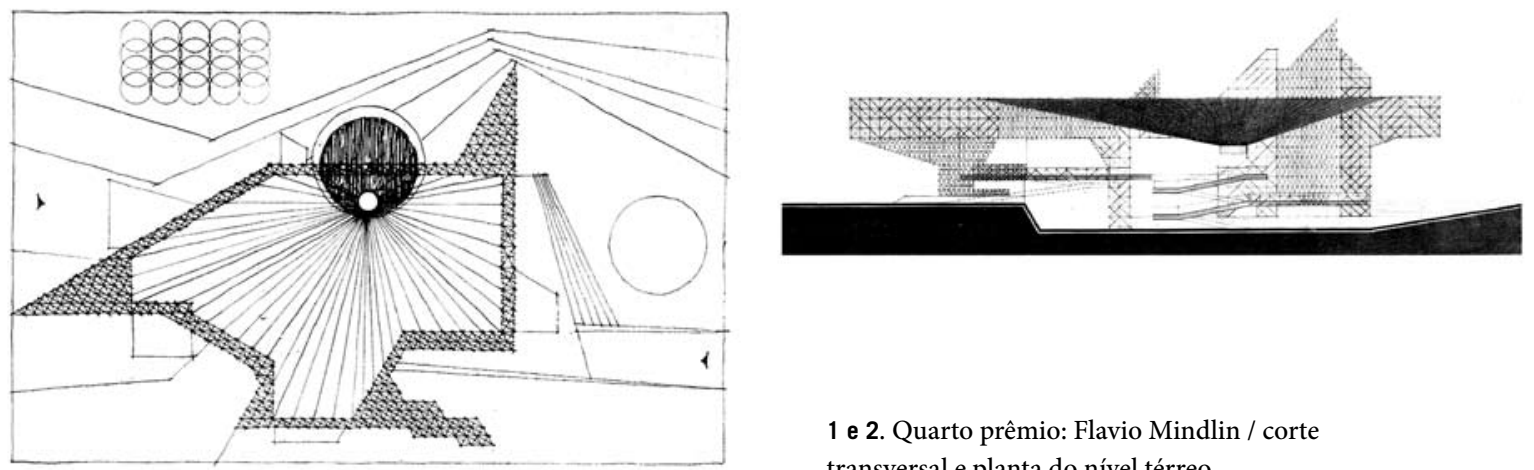

1 e 2. Quarto prêmio: Flavio Mindlin / corte transversal e planta do nível térreo 
sistemas construtivos, como fazem os outros projetos. Aqui é preciso interpretar a perspectiva apresentada - que é o único desenho que explica o pavilhão como um todo - para compreender melhor as características construtivas do pavilhão: de acordo com o memorial descritivo, ele desenvolve um partido mais voltado a ser um "marco na paisagem", do que uma intervenção discreta, ao mesmo tempo em que propõe um percurso definido, através de usos rígidos e previamente determinados do espaço.

O projeto apresentado pela equipe de Ivan Mizoguchi, do Rio Grande do Sul, tem como ponto de partida a criação de uma praça elevada sobre todo o terreno ${ }^{35}$. Os programas específicos estão distribuídos ao longo da praça, em subsolo e também num volume elevado, um prisma em treliça metálica espacial apoiado sobre 4 pilares de concreto. Se a cobertura única transparente, apoiada sobre 4 pilares, era um ponto de semelhança entre este projeto e o vencedor do concurso, ao mesmo tempo, a equipe afirma a intenção de isolar o pavilhão dos limites do terreno e de seus vizinhos laterais, já que não se sabia a priori quais eram esses edifícios. 0 uso da estrutura em treliça especial repete o discurso do pavilhão "desmontável", "transitório", reafirmando a flexibilidade. Segundo a pesquisa apresentada na tese de doutorado de Valéria Fialho, que se dedicou a estudar especificamente os projetos apresentados em concursos, o discurso da "flexibilidade" estava em voga no debate arquitetônico do período ${ }^{36}$. No entanto, a maneira como este projeto emprega a estrutura tubular no sentido da transitoriedade do pavilhão, é distinta daquela apresentada no projeto da equipe de Flavio Mindlin Guimarães: para a autora, Mindlin usa os perfis tubulares e braçadeiras como um "símbolo" da transitoriedade ${ }^{37}$, a medida em que propõe a utilização desse material como uma espécie de vedação semi-transparente, mas que ao mesmo tempo poderia ser feita com qualquer outro material, transformando-o mais numa representação de uma idéia do que efetivamente no elemento que a concretiza. Já no projeto de Mizoguchi, o uso da estrutura tubular é o que dá forma ao edifício como um todo, é sua própria estrutura, e ao mesmo tempo, é o que permite que os arquitetos obtenham "a transparência desejada na conceituação da proposta, [...] não como um símbolo, mas a favor da simbologia". ${ }^{38}$

Por fim, o projeto da equipe de Artur Lício Pontual, do Rio de Janeiro propõe o pavilhão "como uma via aberta por onde circularão continuamente os visitantes" ${ }^{39}$, a partir da qual se distribuem três "núcleos de espetáculo" e a exposição de objetos. A partir dessa descrição,

\footnotetext{
"Pavilhão de Osaka - 4 prêmio". Acropole n.361, maio, 1969, p.26.

Valéria dos Santos Fialho, Arquitetura, texto e imagem: a retórica da representação nos concursos de arquitetura. FAUUSP, 2007, (Tese de Doutorado), p.149.

37 Idem, ibidem, p.151.

38 Idem, ibidem, p.154.

39 "Pavilhão de Osaka - $4^{\circ}$ prêmio". Acropole n.361, maio, 1969, p.27.
} 

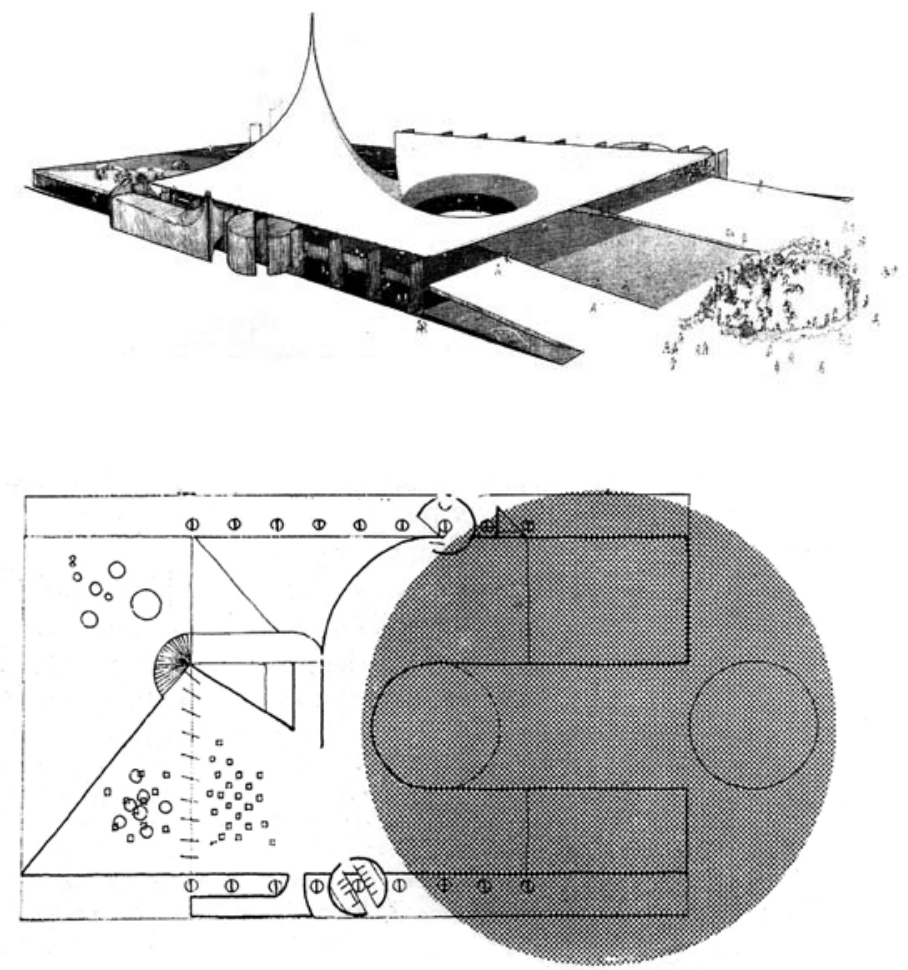

1 e 2. Quarto prêmio: Sigbert Zanetini/

perspectiva externa e planta do nível térreo
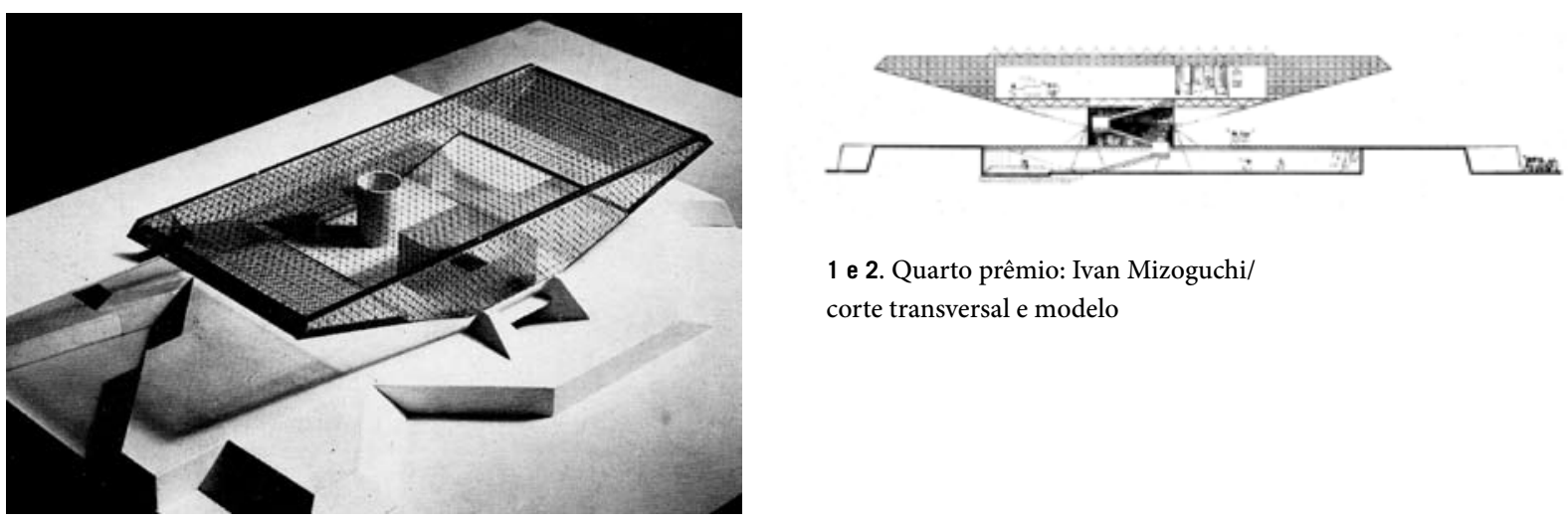

1 e 2. Quarto prêmio: Ivan Mizoguchi/ corte transversal e modelo 

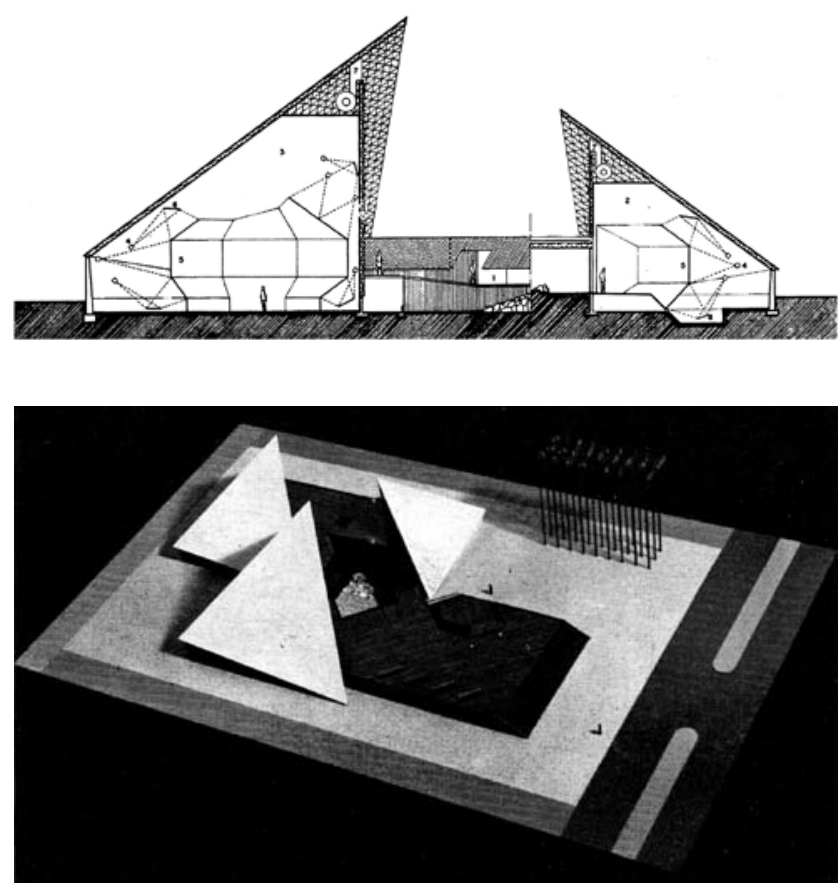

a equipe afirma a integração do projeto arquitetônico com a mostra, fruto do trabalho de uma equipe multidisciplinar que definiria os conteúdos e disposição da mostra. Assim, a planta mostra uma área recortada em três núcleos principais e articulados entre si, com uma "fragmentação característica de um espaço museográfico" ${ }^{40}$, e aparentemente, não parece ter a intenção de criar um marco ou mesmo expressar um discurso através do edifício do pavilhão, mas sim prestar-se àquilo que poderia ser visto como sua "função" estrita: servir de abrigo - ou de cenário - para uma mostra específica. Nesse sentido, assim como o projeto de Zanettini, ao menos a partir do material publicado na revista, não se preocupa em especificar as soluções estruturais nem os elementos da construção que serão utilizados, a ênfase, em ambos os casos, é naquilo que o pavilhão contém.

$\mathrm{O}$ arquiteto Francisco Spadoni ${ }^{41}$, ao estudar os projetos vencedores do concurso, considera que a dificuldade que o júri sentiu em escolher os outros projetos era um reflexo

40 Idem, ibidem, p.151.

41 Francisco Spadoni, A transição do moderno: Arquitetura Brasileira nos anos 1970. FAUUSP, 2003. (Tese de Doutorado). pp.270-286. 
de um "pluralismo", que já se fazia notar a partir daquele momento, e "que se afastava das posições canônicas das versões oficiais do moderno brasileiro". Para ele, o júri buscava, nesse sentido, aquilo que the era familiar e reconhecível como representante da arquitetura brasileira ${ }^{42}$, e que não era possível de ser reconhecido claramente na amostra dos projetos classificados, que demonstravam uma diversidade de tendências que começavam a despontar. E nesse sentido, a escolha do Pavilhão de Paulo Mendes da Rocha, segundo ele, teria como motivação também a procura desta linguagem familiar ${ }^{43}$.

O conjunto dos projetos premiados no concurso de Osaka representa um material bastante diverso, e por isso mesmo, possível de suscitar muitas leituras acerca deste período específico, entretanto, sua pouca divulgação e escassez de material disponível dificulta análises mais precisas. No ano em que foi realizado, apesar da grande mobilização que o concurso causou entre os arquitetos, as revistas especializadas brasileiras não deram nenhuma atenção ao projeto, com exceção da Acrópole, que publicou os artigos aos quais nos referimos anteriormente. Não somente em relação ao projeto brasileiro: de fato, pouco se divulgou sobre a Exposição em Osaka e os outros pavilhões nas revistas especializadas nacionais, não há qualquer outra menção nas daquele período sobre o evento nem sobre os projetos classificados.

Investigar as razões deste silêncio seria uma tarefa que foge ao escopo deste trabalho, pois certamente essa compreensão perpassa a necessidade de um estudo mais amplo acerca do campo profissional no país durante a década de 60 . Pois a pouca divulgação não diz respeito ao pavilhão de Osaka especificamente, é possível que seja muito mais o reflexo de um momento de incerteza da situação profissional que antecede a década de 70 e o "milagre econômico".

A própria situação do mercado editorial atestava a incerteza desse momento; entre as principais revistas especializadas que colaboraram na divulgação da arquitetura no Brasil na década anterior, são poucas as que se mantém em funcionamento nos últimos anos da década de 60. Muitas delas tiveram sua publicação encerrada em meados da década, como Módulo e Habitat, outras nem ao menos conseguiram chegar nos anos 60, como é o caso da $A D$ e da $B A C^{44}$. Neste quadro, ao final da década de 60, apenas a Acrópole e a revista Arquitetura, publicada pelo IAB do Rio de Janeiro se mantém com regularidade, tornandose os principais veículos de difusão de projetos e debates no meio especializado ${ }^{45}$. Nesse

42 Franciso Spadoni, op. cit., p.196.

43 Idem, ibidem, p.197.

44 A última edição da Módulo foi a de $n^{\circ} 10$, de 1965 e da Habitat n 84, de 1965. Já a $A D$ encerrou sua publicação com o no 27, de 1958 e a $B A C$, com o no 12, de 1957.

45 E ainda assim, Arquitetura encerra sua publicação em de 1969. A Acropole resistiu até 1971. 
sentido a pouca divulgação da Expo70 e dos projetos vencedores do concurso é também uma contingência editorial, e a publicação na Acrópole é praticamente a única saída para a divulgação de qualquer projeto.

Entre as revistas estrangeiras, também é possível perceber que o Pavilhão do Brasil não chamou muita atenção no conjunto dos projetos da Feira de Osaka. São diversas as publicações que tratam da Expo70, desde o final de 1968, quando alguns países já começaram a divulgar os projetos de seus pavilhões, entretanto o pavilhão brasileiro aparece brevemente em apenas duas delas: uma breve menção na Architectural Review em julho de 1970, numa edição que trazia um apanhado geral dos pavilhões, e outra na Techniques et Architecture, durante a obra, em 1969. É certo que nesses anos finais da década de 60 os interesses internacionais e os debates em curso eram outros, e a produção brasileira já não ocupava as pautas da crítica internacional nas revistas há muito tempo.

Uma evidência desse silêncio é, mais uma vez, a quantidade de artigos publicados sobre arquitetura brasileira nas revistas internacionais do período: enquanto no ano de 1960 foram publicados 41 artigos no tema, a grande maioria tratando da nova capital que se inaugurava, nos dez anos seguintes foram publicados apenas 54 artigos sobre a produção brasileira.

Em nosso levantamento nas revistas estrangeiras realizado durante o estudo da revista Zodiac, nos estendemos até o ano de 1970, justamente com o objetivo de verificar em que termos a idéia difundida a partir do artigo de 1960 da Zodiac, de que a arquitetura moderna brasileira não se restringia ao grupo de Lucio Costa, poderia ter repercutido nos anos seguintes. Procurávamos as menções sobre São Paulo e a atividade da arquitetura na cidade a partir desse período, e qualquer referência ao Pavilhão de Osaka e ao grupo ligado à Vilanova Artigas.

Como já era esperado, há pouquíssimos registros nas revistas estrangeiras que mencionam projetos em São Paulo até 1970. De um modo geral, é possível atestar a relevância da produção dos arquitetos estrangeiros atuantes na cidade na década de 50 (Warchavchik, Korngold, Rudofsky, Lina Bo Bardi, Rino Levi), que aparecem em número razoável de artigos, quando se trata de crítica de arquitetura brasileira que não seja a arquitetura carioca. Com exceção dos estrangeiros, não há nos periódicos internacionais, após Brasília nenhum tipo de leitura que tenda a enxergar um movimento específico em São Paulo, e nem mesmo menções individuais aos arquitetos que, no campo local, vinham ganhando projeção, como o próprio Vilanova Artigas. Se, no contexto local, a produção paulista ganha alguma notoriedade, estes projetos não são nem se quer mencionados nos veículos especializados da década de 60 , não há qualquer alusão a "escola" ou formação de uma alternativa - no sentido de uma produção em número relevante de projetos que compartilhem das mesmas pesquisas - à arquitetura carioca. 
Há, entretanto, uma curiosa exceção nesse quadro: a revista japonesa Kokusai-Kentiku, em 1967 dedicou um grande espaço à "arquitetura paulista", com um artigo de 22 páginas intitulado "Architectural works around Sao Paulo after Brasilia"46. Nele, constam projetos de Paulo Mendes da Rocha, Pedro Paulo Saraiva, Jorge Wilhem, Joaquim Guedes, Fabio Penteado, Carlos Millan, entre outros. Por este quadro de arquitetos, considerados os grandes expoentes da "escola paulista", é possível supor que o teor da matéria seja justamente no sentido de reconhecê-los como um grupo, no momento em que se encontravam no auge de suas realizações.

A tentativa de compreender o relativo silêncio das publicações estrangeiras sobre 0 pavilhão de Osaka nos revela, acima de tudo, que os interesses da crítica e os temas que permeavam o debate internacional naquele momento não correspondiam ao que era produzido no país. Não se tratava de um desinteresse pelo projeto do pavilhão estritamente, ao contrário, a ausência da produção brasileira como um todo demonstra que naquele momento essa produção não correspondia aos temas que ocupavam a crítica internacional.

\section{3. o projeto vencedor, empenho em ir além}

"Ele não foi pensado como um envoltório ou uma embalagem para proteger um conjunto de amostras ou mercadorias produzidas por uma população que obviamente produz dentro de suas peculiares condições de produção e que assim mesmo se faz reconhecer criadora. O empenho dos arquitetos nesse ir além, é também uma maneira de apresentar as possibilidades que se acumulavam historicamente, dentro de um país, no sentido de produzir projetos de universal interesse." 47

A equipe de Paulo Mendes da Rocha, vencedora do concurso do Pavilhão tinha como colaboradores os arquitetos Julio Katinsky, Ruy Othake, Jorge Caron e Marcelo Nitsche e a artista plástica Carmela Gross. O projeto do Pavilhão pode ser descrito a partir de suas características como construção: define-se por uma cobertura em concreto armado e

46 Esta publicação foi consultada e reproduzida na pesquisa que realizamos na Avery Library.

47 Flavio Motta, "Arquitetura brasileira na Expo-70", Textos Informes, op. cit., p.31. 
protendido, de $32,5 \times 50 \mathrm{~m}$, constituída por duas vigas longitudinais que possuem altura variável a partir de $2 \mathrm{~m}$, e um conjunto de vigas transversais espaçadas a cada $2 \mathrm{~m}$, também com $2 \mathrm{~m}$ de altura. Entre cada conjunto de vigas está disposta uma grelha de domos de forma piramidal, fechados com vidro. Essa cobertura está apoiada sobre quatro apoios desalinhados entre si, de modo que tem balanços desiguais nas pontas. Está disposta no sentido transversal do lote de 50x80m. A articulação entre os pilares e a cobertura é feita através de "aparelhos de apoio", muito utilizados no Japão, que permitem a movimentação da estrutura.

O terreno, coberto por uma camada de asfalto, é construído de modo a conformar uma topografia ondulada que se eleva no encontro dos pontos de apoio da cobertura, de modo a engolir três dos pilares. 0 quarto pilar é desenhado como a intersecção de dois arcos, definindo a sua volta uma área plana para a qual os "morrinhos" se voltam, denominada no projeto como "Largo do café", aludindo ao relevo de um anfiteatro natural.

Complementando esta área aberta principal do Pavilhão, há duas áreas em subsolo, uma sob a projeção da cobertura, e a outra em uma das extremidades do lote. A primeira, destinada aos espetáculos e as exposições temporárias, acessível por duas rampas ${ }^{48}$, concentra também as áreas de apoio ao púbico e sanitários. A segunda, localizada no limites posterior do lote, denominada de "anexo do Itamaraty", se destina aos escritórios e tem acesso mais reservado, por uma rampa na lateral do lote, sendo iluminada através de uma janela inclinada em toda a sua extensão. A partir da rua, através da topografia artificial, o terreno se inclina em direção ao fundo, de modo que o "anexo do Itamaraty" não está em subsolo, mas a meio-nível em relação ao chão no seu exterior, assim, de dentro do anexo, vê-se o Pavilhão.

O material apresentado no concurso era composto por algumas fotos da maquete, 0 conjunto das quatro elevações do pavilhão, as plantas e cortes e o memorial descritivo. A maquete mostrava o essencial: apenas o chão e a cobertura, elementos que definem o projeto do Pavilhão. 0 material apresentado no concurso também foi publicado na Acrópole 361, junto aos outros projetos premiados. Alguns meses depois, a Acrópole publicou o pavilhão na fase final da obra, apresentando a versão definitiva do projeto - com pequenas modificações em relação aquela apresentada no concurso - acompanhadas de um texto de Flavio Motta sobre o Pavilhão.

O material apresentado no concurso, e especialmente os desenhos, podem ser entendidos também como um modo de ler o projeto, a medida em que realçam as características que a equipe considera mais relevantes. É o caso, por exemplo, das elevações apresentadas: prevalecem em cada uma delas uma grande área de entorno, que segundo 


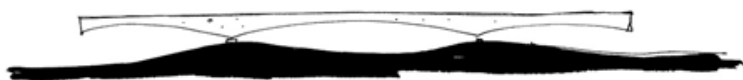

1. Fachada do paViLHäo, uma das frentes DE ACESSO.

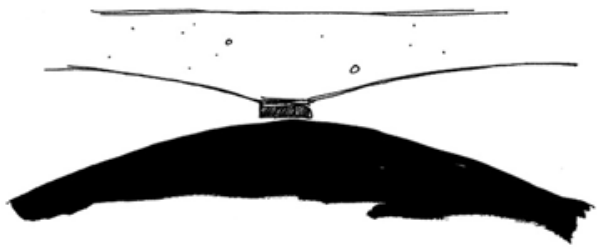

2- ARTICULDCEDO NOS APOIOS. SD̈O APARELHOS

DE ARTICULACSAOO DE LINHA INDUSTRIAL

COMUMENTE USADOS EM PONTES E VIDDUTOS

NO UAPÖO.

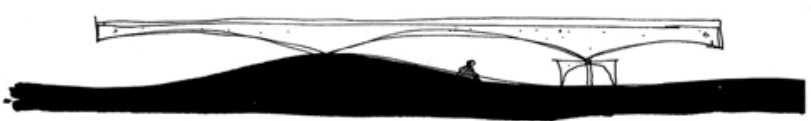

$3-$

OUTRA FACHADA DO PAVILHĀO E TAMBEM

FRENTE DE ACESSO. OOB A CALCSADA

RSTA O ANEXO DO ITAMARATY.

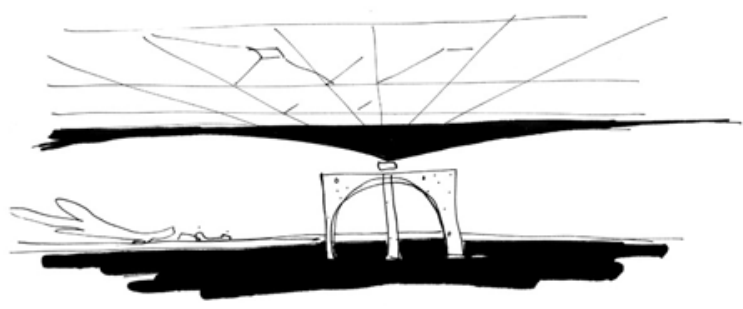

$-4-$

resinto interno, lugar que no projeto FICOU SE CHAMANDO 'LARGO dO CAFE'".

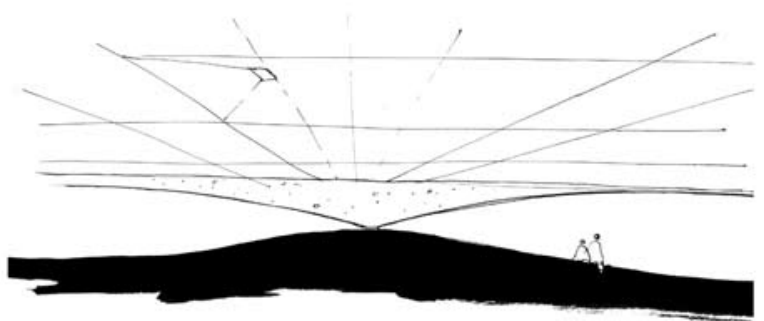

$-5-$

outra vista intRrana. os DESNIVEIS

NO CHÄO FAZEM CRSCER o ESPACO INTERNO

E. TAMEEM ORGANIZAM UM POUCO AS

E.NTR $\triangle D \Delta S$. 


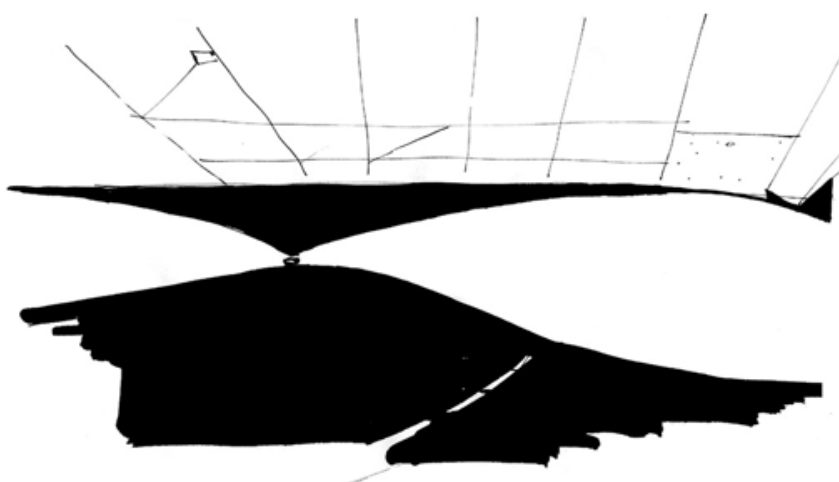

AS FDCHADAS LDTERDIS ESTD̄O REBOTIDAS NA COBRRTURA JA QUE NäO HA RECUOS nOS LADOS.

PLANO dA coBrRturA tANGENCIA OS ARCOG DAS DUAS VIGAS PRINCI PAIS ASSIM $\triangle$ LUZ $\triangle$ JUDA A FUN' DIR MELHOR DOHS SOSEMAS $\triangle$

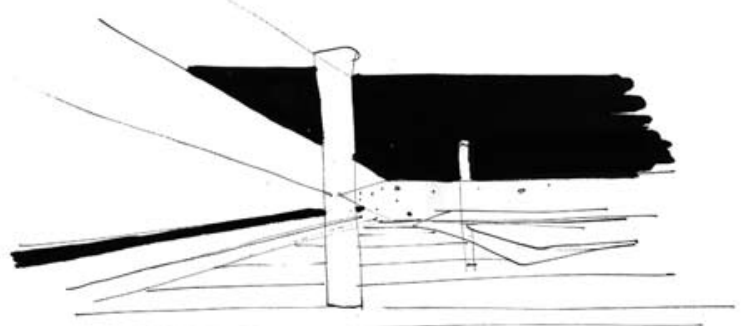

7. INTERIOR DO ANRXO DO ITAMARDTY

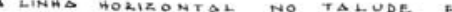

UMA JANELA DE DISTRIBUIĢ̄̃O DO AR CONDICIONADO.

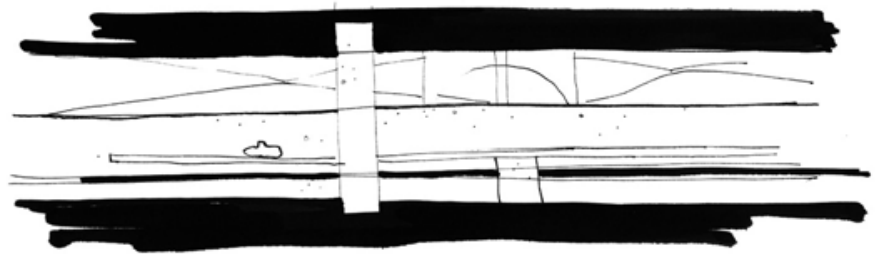

8- INTERIOR DO ANE.XO DO ITAMARATY

1 a 8. croquis e legendas de Paulo Mendes da Rocha para apresentação sobre o Pavilhão. 

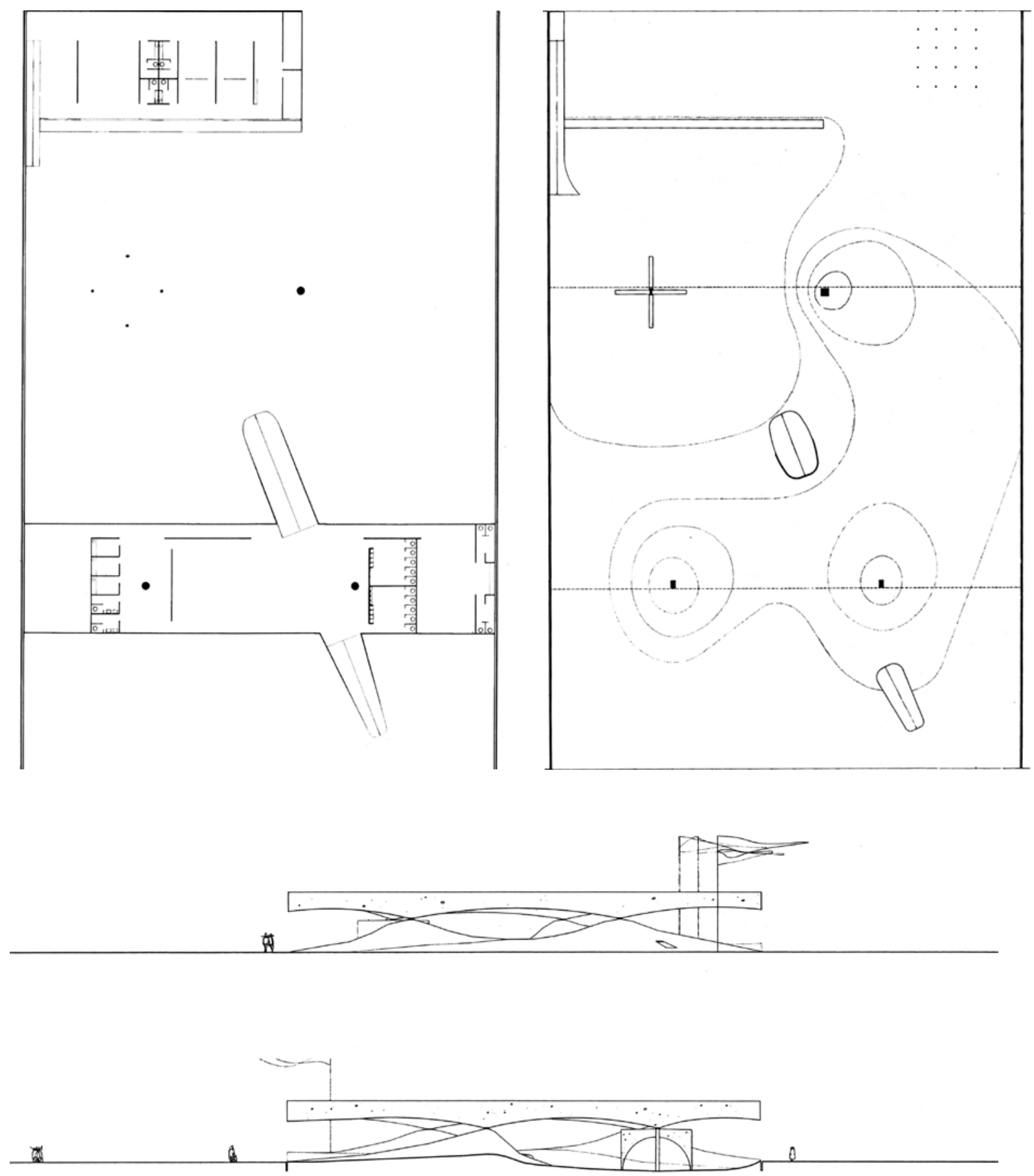

1 a 5. PAVILHÃO DO BRASIL

versão do projeto apresentada no concurso PLANTA DO SUBSOLO / PLANTA DO TÉRREO ELEVAÇÕES

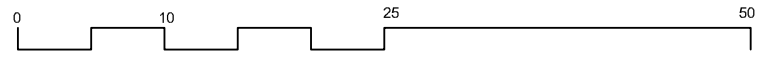



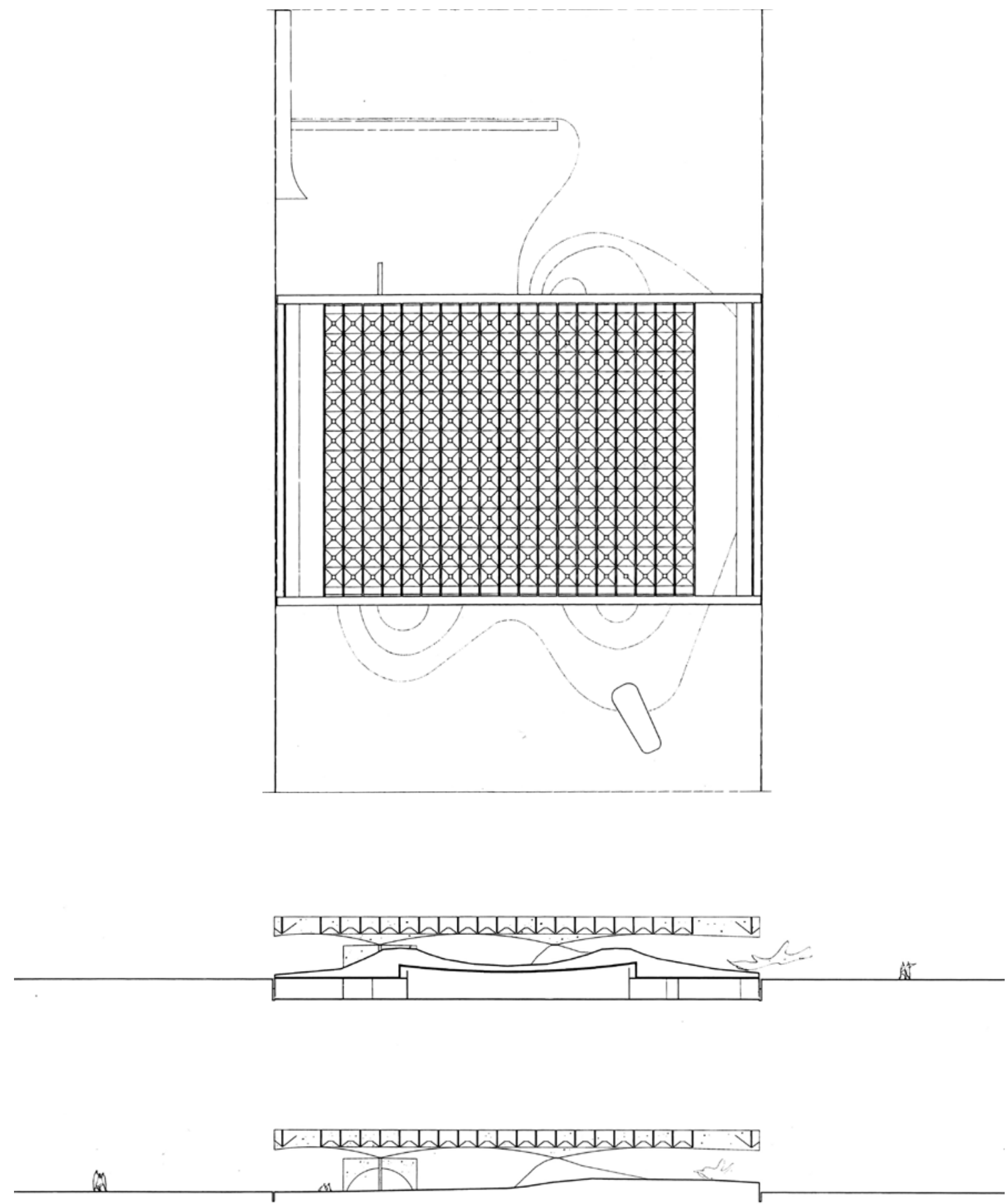

1 a 3.

PLANTA DA COBERTURA CORTES TRANSVERSAIS

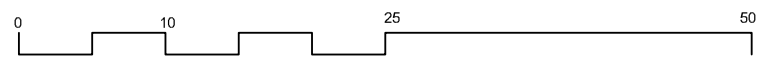


Valeria Fialho, enfatizam que o espaço que envolve o pavilhão é essencial ao projeto ${ }^{49}$. Além disso, essa opção pelas elevações com "amplitude" reforça o caráter do Pavilhão como um espaço essencialmente aberto às edificações vizinhas e à rua, sem qualquer barreira entre ele $\mathrm{e}$ o resto da Feira. Além disso, nas quatro elevações um terceiro elemento ganha importância: os mastros das bandeiras, "um contraponto vertical" 50 que reforça a horizontalidade do conjunto. Além dos desenhos, o memorial apresentado ao concurso é bastante sucinto, e se diferencia dos textos apresentados pelos outros projetos por descrever a construção através de imagens poéticas, utilizando referências que vão explicando cada espaço do projeto sem descrições literais nem argumentos técnicos:

"A feira internacional de Osaka é um encontro de grande significado humanístico; um projeto para o mundo em que vivemos.

O Pavilhão do Brasil une a Praça da Amizade com o Grande Parque, num gesto de confraternização, onde mostrará o trabalho de seu povo como contribuição para esse Projeto. É aberto para os pavilhões vizinhos - Checoslováquia e Etiópia.

o chão será o mesmo que o de Osaka.

Uma sombra como a das árvores cobre parte do recinto.

Chão de estrelas.

O piso terá ondulações suaves como o das ruas de uma cidade onde o passeio e o encontro se dão naturalmente. $O$ anfiteatro natural no recinto, permite o espetáculo que, com a localização dos camarins e salas de montagens, poderá criar situações imprevistas.

A praça do café, sob os arcos, será o descanso, ponto de parada e reunião. 0 anexo do Itamaraty é fecho natural do recinto, sem prejuízo da visão para o Grande Parque.

As comunicações, com os recursos que a ciência moderna dispõe, nos igualam e propõe esse encontro em Osaka. A luta por essa conquista será contada através da obra dos nossos cientistas e artistas. Nesse sentido o Brasil fixa com Brasília e as novas cidades essa busca de um espaço e um tempo de constante significação humana. Esse trabalho traz a história para o presente e se afirma como projeto. "51

O memorial, elaborado por Flavio Motta, apresenta a Feira de Osaka como "um encontro de grande significado humanístico; um projeto para o mundo em que vivemos". Essa

49 Valéria Fialho, op. cit., p.154.

50 Idem, ibidem, p.155.

51 Memorial Descritivo para o Pavilhão de Osaka, publicado na revista Acropole, n. 361, 1969, p.15. Ainda que o memorial seja de autoria "da equipe" [assim como todo o material encaminhado], segundo depoimento de Paulo Mendes da Rocha a autora, o memorial foi escrito por Flavio Motta, sintetizando as idéias coletivas que nortearam o projeto. 

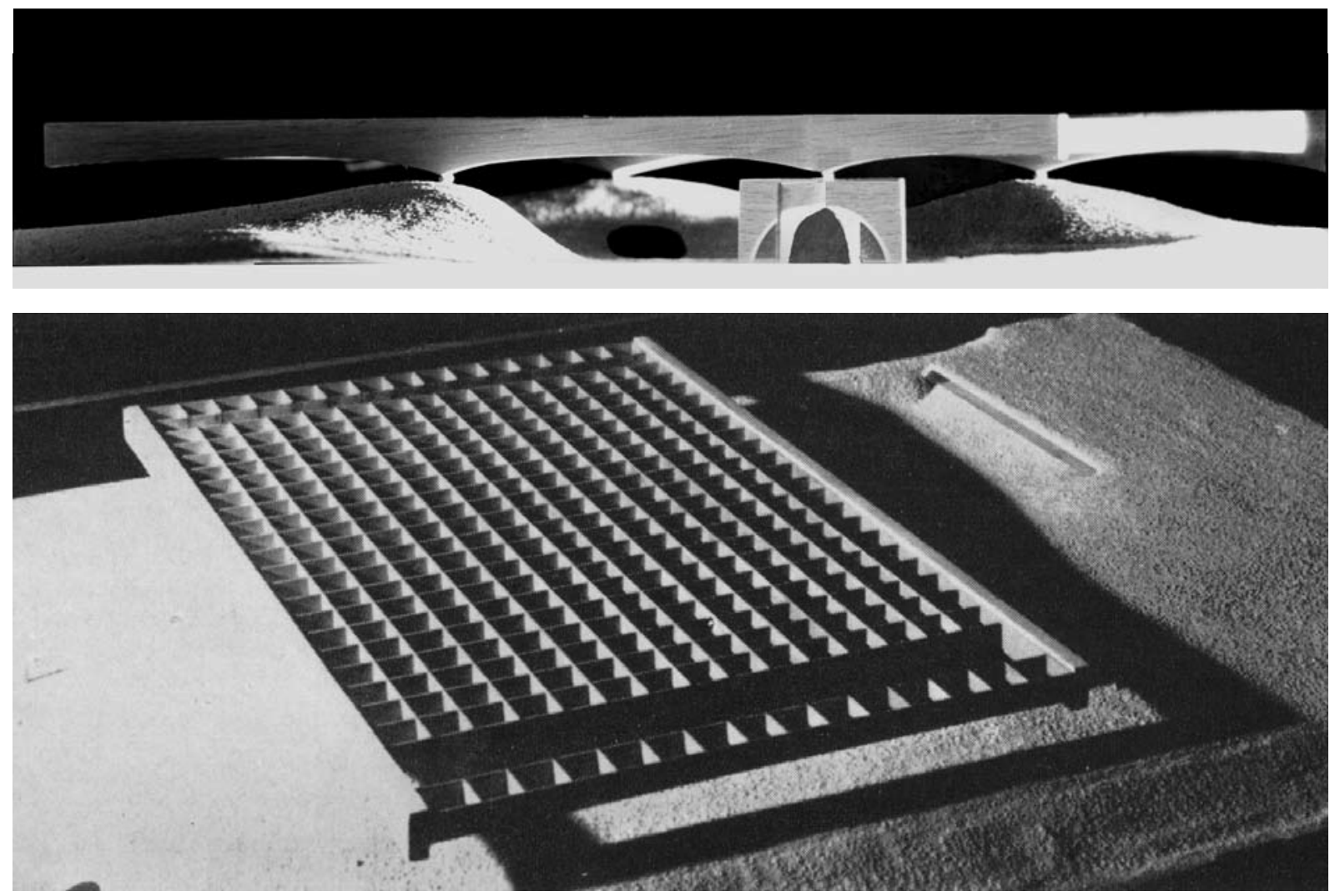

1 e 2. Maquete confeccionada pela equipe vencedora para o concurso.

3. A equipe definiu a topografia do projeto inicialmente na própria maquete e a transferiu para os desenhos utilizando um instrumento para aferir os níveis [par de "réguas" à direita]. Na foto, Marcelo Nitsche e Carmela Gross.

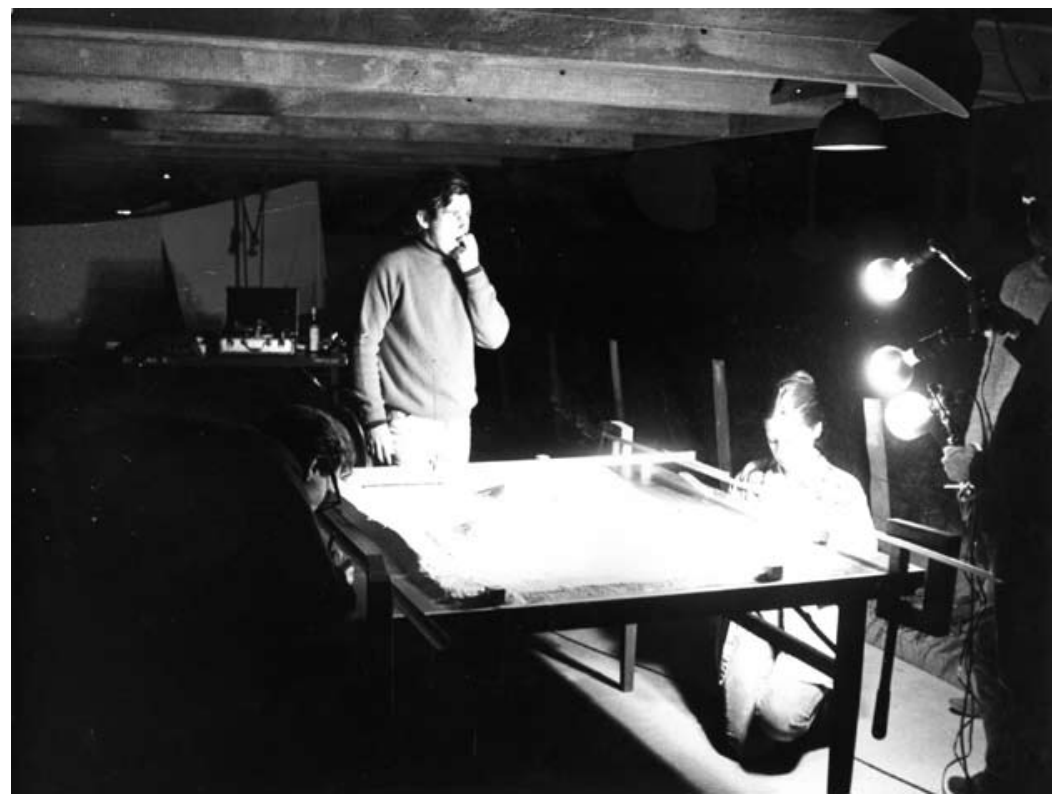


certeza, além de dignificar o propósito de se fazer um projeto para essa ocasião $0^{52}$, de certo modo também contém as justificativas do partido, na medida em que agrega todos os valores simbólicos contidos no projeto, e ao mesmo tempo não se perde em tentativas de discutir as possibilidades tecnológicas nem comparar-se aos outros países. Em outras palavras, o propósito de estar na Feira não é demonstrar nosso estágio de desenvolvimento, mas sim estar presente na confraternização universal dos povos.

E no mesmo sentido, não há nenhuma descrição do projeto em termos "técnicos": não se apresenta o sistema estrutural, construtivo, etc. Por um lado, esse recurso só é possível pela concisão do projeto, que pode ser facilmente compreendido com três ou quatro desenhos, e muito enfaticamente, através das fotos da maquete. Por outro lado, fica claro também que o propósito do memorial, é evidentemente afirmar o sentido poético, simbólico e "humanístico" das decisões projetuais.

Nesse sentido, o que se diz da cobertura é que ela é uma "sombra", e que projeta "um chão de estrelas". Toda a operação topográfica do térreo, que organiza os acontecimentos e engloba os apoios, é descrita como "ondulações suaves como o das ruas de uma cidade", e do mesmo modo, a livre circulação, a ausência de barreiras e a continuidade espacial com os vizinhos são descritos com a bela imagem de que "o chão será o mesmo que o de Osaka".

A medida em que o pavilhão é aberto a todos e aos encontros que "se dão naturalmente", os percursos possíveis no seu interior são muitos; não há caminhos definidos e as situações se definem a partir do uso, como o do espetáculo que se monta a qualquer momento nessa rua que é também um anfiteatro natural. Esse sentido encontra-se também na possibilidade dos eventos se realizarem imprevistamente e em qualquer lugar, como as apresentações mambembes em qualquer feira de uma cidade. A praça do café, o maior recinto plano sob a cobertura, é demarcada pelo pilar em duplo arco, de claro sentido simbólico e urbano, como um contraponto à topografia "natural" dos outros apoios, marcando o lugar de encontro e estar do Pavilhão. 0 arco representa, em si mesmo, o conhecimento técnico do homem.

No processo de elaboração do projeto, no entanto, a forma em arco do pilar surgiu num momento posterior, depois de a equipe ter realizado estudos com pilares de outros formatos. Por sua força simbólica e pelo modo como estrutura o discurso de projeto contrapondo à paisagem da topografia ao seu recinto, referindo-se a idéia de urbanidade - parece-nos difícil imaginar a idéia do projeto sem o arco, entretanto, é natural que tenha sido o resultado de um processo de maturação das questões mais importantes ao projeto. Ao mesmo tempo, a imagem o projeto com um pilar que não é o duplo arco, enfatiza a 

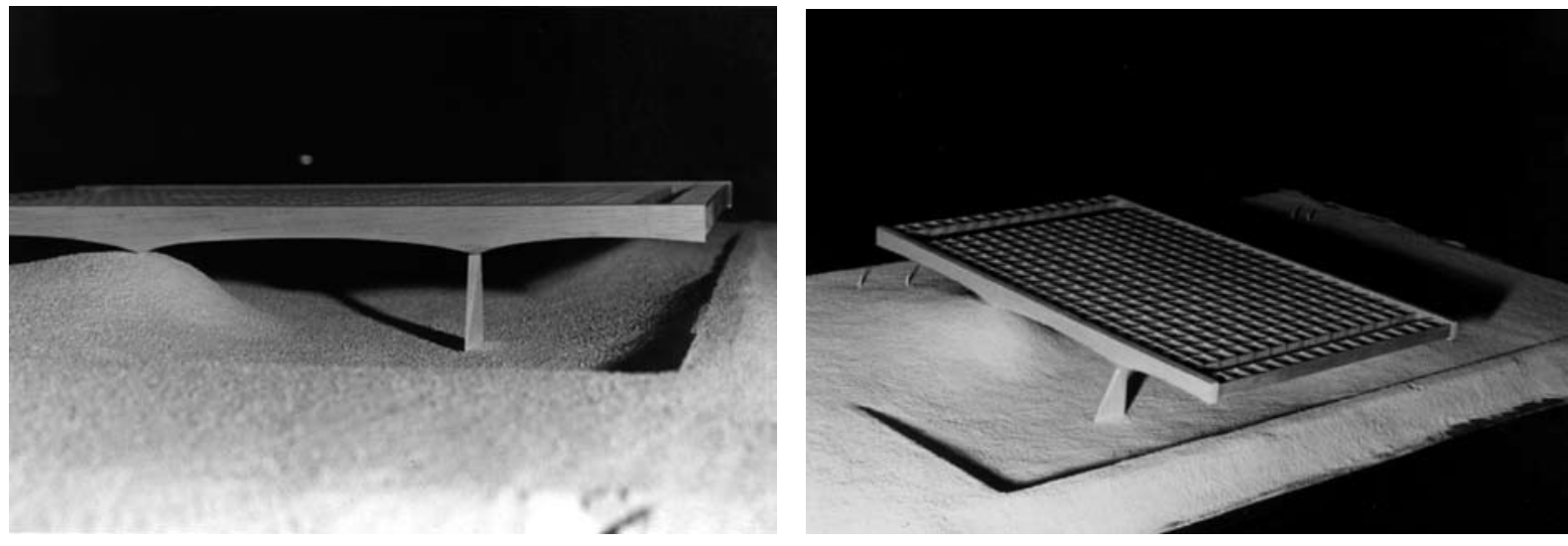

1 e 2. Maquete do Pavilhão - estudo para o pilar da Praça do Café, anterior à solução em arco.

relevância dessa escolha e o papel fundamental desta decisão no conjunto do projeto.

Ao mesmo tempo em que entender as decisões tomadas pela própria equipe, através do material de apresentação do projeto, nos permite delinear algumas questões relevantes ao estudo do projeto de Pavilhão de Osaka, é necessário também compreender de que modo foi considerado nas diversos leituras críticas realizadas ao longo dos últimos anos em que seu projeto é apresentado. Ao nos depararmos com essas análises, é possível identificar certas recorrências nas abordagens e certas premissas que compartilham. De um modo geral, a maior parte dos trabalhos que se referem criticamente ao Pavilhão ${ }^{53}$ são estudos acadêmicos de caráter historiográfico, que acabam por inserir o projeto nas construções de suas narrativas acerca da história da arquitetura moderna brasileira. Tratado freqüentemente como obra exemplar, tem nessa diversidade de registros um documento de sua qualidade como obra e de sua relevância para a história da arquitetura.

Se nos anos que sucederam a sua realização o Pavilhão do Brasil não encontrou muita ressonância entre a crítica especializada, no escopo das pesquisas acadêmicas contemporâneas, é freqüentemente destacado naqueles trabalhos que se dedicam a estudar a história recente da arquitetura moderna brasileira, e mais enfaticamente nos que têm como foco sua vertente de São Paulo. Com efeito, uma das leituras recorrentes do projeto do pavilhão é justamente na perspectiva de sua inserção numa linhagem "paulista", sua representatividade e seu caráter exemplar nesta vertente. De um modo geral, são trabalhos que investigam um estudos nos quais há análise crítica acerca do projeto, no sentido de auxiliar a nossa leitura. 

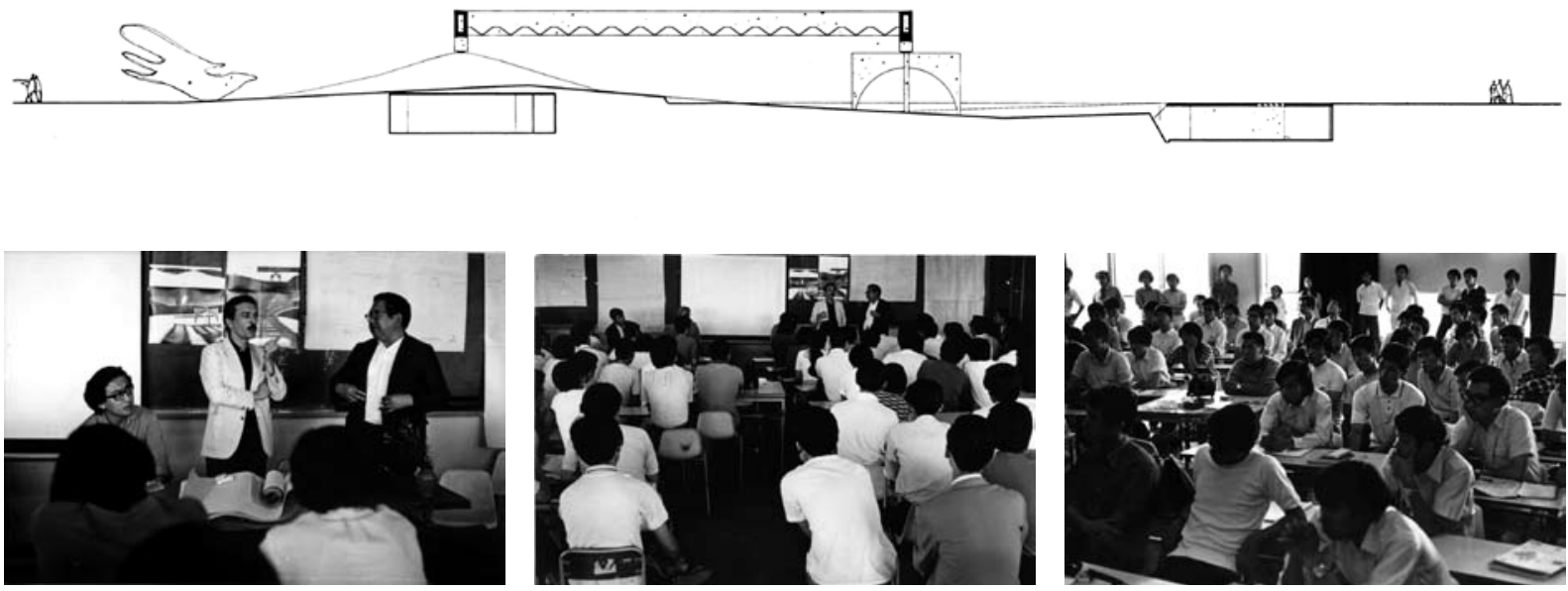

1. CORTE LONGITUDINAL, versão do projeto apresentada no concurso, mostrando o Anexo do Itamary a direita.

2. Ruy Othake, Paulo Mendes da Rocha e o calculista Siguero Mitsutani apresentam o projeto do pavilhão para os estudantes da Universidade de Kyoto.

amplo leque de projetos e obras, numa leitura mais panorâmica interessada em compreender movimentos mais abrangentes da história recente da arquitetura brasileira, do que se deter em um projeto especificamente. Nos interessa percorrer alguns desses trabalhos para melhor inserirmos nosso estudo acerca do Pavilhão.

Entre aqueles trabalhos que têm como foco o estudo da arquitetura produzida em São Paulo a partir da constituição de uma "escola" e analisam o pavilhão inserido nesta linhagem, um exemplo é a tese de doutorado de Ruth Verde Zein ${ }^{54}$. Tendo como ponto de partida um vasto levantamento de obras, a autora pretende verificar a pertinência em classificar as obras realizadas em São Paulo em determinado período como exemplares de uma "escola paulista brutalista", categorias que são descritas e demarcadas logo no início de seu estudo.

O Pavilhão de Osaka é analisado num conjunto de edifícios culturais e num recorte temporal que, segundo ela, corresponde ao período das "obras exemplares do brutalismo paulista", de 1961 a $1973^{55}$. Nesse conjunto, a autora destaca o Pavilhão pela qualidade e

54 Ruth Verde Zein, A arquitetura da escola paulista brutalista: 1953-1973. Porto Alegre, UFRGS, 2007, (Tese de Doutorado).

55 Ruth Verde Zein, cap. 7.4.6. "Edifícios culturais e museus: cultura como representação". op. cit., p.170-203. 0 item 7.4 do trabalho de Ruth Verde Zein trata desse período. 
originalidade de seu projeto: "trata-se de uma obra que exemplifica com galhardia um dos melhores momentos da arquitetura paulista" ${ }^{26}$, e analisa a ocasião do concurso como um "evento extremamente significativo", num contexto em que, para ela, a arquitetura paulista já poderia ser considerada como um movimento consolidado, após ter percorrido uma década de "experimentações e realizações fecundas e inovadoras", firmando-se a partir daí como a vertente predominante no país ${ }^{57}$.

Segundo a autora, tratava-se de um momento em que o "brutalismo paulista" estava em expansão pelo território nacional, pois era possível identificar suas tipologias mais características sendo desenvolvidas em diversas regiões. Nesse sentido, a escolha do projeto de Paulo Mendes da Rocha para representar o país na Feira de Osaka assumia ares de oficialização de seu caráter "nacional", ocupando o lugar que outrora havia sido do grupo carioca ${ }^{58}$. Assim, para ela, o pavilhão representa a disseminação da "arquitetura paulista brutalista" no país e sua celebração como expressão nacional e representativa do que seria uma "nova tradição brasileira", um "marco simbólico da mudança de paradigma da arquitetura nacional". E segundo a autora, o pavilhão é justamente o momento inaugural de uma "década de expansão [...] e exacerbação das pautas brutalistas, já então presentes não apenas em São Paulo, mas com ampla disseminação em todo o Brasil." ${ }^{59}$ Para a autora, a partir de 1970 os programas, as tipologias, e mais precisamente o ideário da "escola paulista brutalista" se difundem pelo país, conduzindo esse movimento ao seu auge ${ }^{60}$, que coincide também com 0 auge do chamado "milagre econômico".

Na contra-mão desta visão do pavilhão como "momento alto" de uma vertente, está outro trabalho que estuda o pavilhão dentro de um amplo conjunto de obras, o livro Arquiteturas no Brasil 1900-1990, de Hugo Segawa61. Nele, o autor considera o pavilhão como o último trabalho da "escola paulista", que se encerraria a partir desse momento, frente ao desgaste e banalização de sua proposta e os desdobramentos da situação política do país:

"O marco simbólico de enceramento desse ensaio de vanguarda arquitetônica foi, sem dúvida, o Pavilhão do Brasil na Feira Mundial de 1970 em Osaka, Japão. [...] Síntese dos aspectos morfológicos mais caros à linha paulista: uma grande cobertura retangular, com iluminação zenital em toda sua extensão, apoiada em apenas quatro

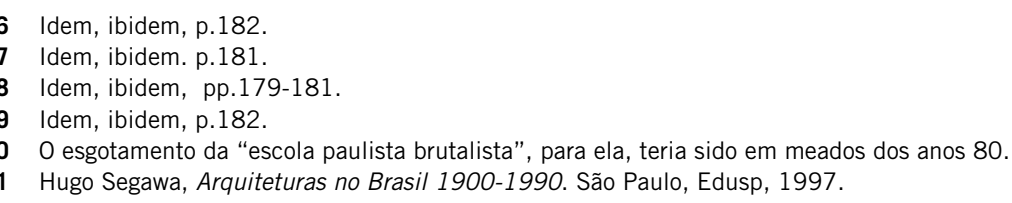


pontos. Espaço coberto, livre: pavilhão que não tem portas, barreiras físicas, o piso "interno" em uma continuidade do chão comum de toda a feira." 62

Segawa analisa o projeto do pavilhão inserido na linhagem do grupo de Artigas, e menciona também as aproximações entre algumas obras da arquitetura deste grupo e 0 'brutalismo', no entanto afirma que denominar esta produção de "brutalista" tem um efeito redutor, que "minimiza as demais influências ou condicionantes significativas na formação desse pensamento"63. Além disso, procura elencar características que aproximem os arquitetos desse grupo, compreender quais as condições que propiciaram o desenvolvimento dessa vertente e mais do que isso, estabelecer sua proximidade com a produção do grupo carioca ${ }^{64}$. Segawa considera a produção paulista muito mais como uma continuidade da "linha carioca" do que efetivamente uma proposta alternativa; nesse sentido, remete a Niemeyer "o caráter mais marcante da arquitetura paulista - a estrutura como arquitetura", e também a Reidy e as outras experiências de construção em concreto armado dos arquitetos cariocas durante a década de 50.

Por fim, não compartilha da idéia de que a década de 70 signifique um momento importante de disseminação dessa arquitetura e sua expansão. Ao contrário, para ele o traço principal dessa produção, a "clareza e a força ideológica em torno dos conceitos de desenho e projeto" perderam o sentido à medida em que começaram a ser repetidos:

"Os anos de 'milagre econômico' burocratizaram as formas originalmente instauradoras de inovações e plenas de conteúdos ideológicos de forte coerência interna. Essas formas foram estampadas indistintamente aos mais diversos programas arquitetônicos, nas mais disparatadas escalas [...] A generalização do modelo banalizou a inovação, a ruptura. Diluía-se e degenerava-se uma visão de arquitetura'65.

Á parte das tentativas de classificação empreendidas por esses dois trabalhos ("escola", "paulista", "brutalista"), é difícil concordar com a idéia de que o Pavilhão de Osaka represente o esgotamento de uma vertente, pois certamente muitos desdobramentos e mesmo continuidades dentro da produção deste grupo podem ser reconhecidas durante os anos que

62 Idem, ibidem, p.157.

63 Idem, ibidem, p.150.

64 Idem, ibidem, pp.147-149.

65 Idem, ibidem, p.157. 
sucedem o projeto do Pavilhão. Pode-se tomar como exemplo a própria produção de Paulo Mendes da Rocha ou mesmo Vilanova Artigas, que desenvolveram diversos trabalhos ao longo dos anos 70 que certamente são possíveis de ser compreendidos inseridos no debate desta "escola"66.

Alguns outros trabalhos se dedicam especificamente ao estudo da continuidade da produção dessa arquitetura na década de 70 , como é o caso da tese de Francisco Spadoni ${ }^{67}$. Ele considera que a década de 70 é justamente o período de transformação das premissas e experiências construtivas que vinham se desenvolvendo desde a inauguração de Brasília, sem que, no entanto, estas sejam abandonadas ou totalmente renegadas ${ }^{68}$. Para ele, tratamse de desdobramentos, que ainda que tenham demonstrado em certos casos o "desgaste do moderno", "a continuidade acrítica das modalidades espaciais sacralizadas", "o ranço de um nacionalismo ainda renitente", foram capazes de gerar uma "sedimentação de uma cultura técnica de grande sofisticação, o amadurecimento de um projeto de origem notável e uma renovação com tópicos também locais. Em síntese: houve uma reconstrução da invenção". ${ }^{69}$

Spadoni procura, em seu trabalho, identificar justamente a permanência dos dilemas do projeto moderno brasileiro na produção que se desenvolve nos anos 70 e o modo como a produção desta década organiza os novos caminhos que se desenvolvem a partir dos anos 80 e 90; em outras palavras, considera a década de 70 um período de transição entre o "moderno" e o "contemporâneo", freqüentemente considerado como um período marcado por um "impasse inventivo" na situação da arquitetura brasileira. Neste quadro, o projeto do Pavilhão de Osaka tem papel importante em sua análise, tanto que dedica uma parte expressiva de seu trabalho a apresentação do Pavilhão e do concurso, utilizando além das fontes já citadas da Acrópole, também uma entrevista com Paulo Mendes da Rocha.

Para ele, a marca mais significativa da década de 70 é justamente a "valorização do sistema portante como definidor de uma idéia de arquitetura" ${ }^{70}$, que muito mais do que "uma ação eminentemente técnica"; era a "sedimentação de uma atitude de projeto", que já podia ser reconhecida em diversos trabalhos de Oscar Niemeyer e Reidy, ou seja, ele era também uma continuidade do que poderia ser considerado uma "tradição" brasileira e da própria arquitetura carioca.

66 No caso de Artigas, podemos citar como exemplo a Rodoviária de Jaú (1973), alguns conjuntos para o CECAP, o Balneário de Jaú (1975), e diversas residências. Já em relação a Paulo Mendes da Rocha, os projetos da Escola do Jardim Calux (1972), o Estádio Serra Dourada (1973) e o projeto para o MAC-USP (1975) são bons exemplos de obras que podem ser inseridas nas discussões da arquitetuta "paulista".

67 Francisco Spadoni, A transição do moderno: Arquitetura Brasileira nos anos 1970. São Paulo: FAUUSP, 2003 (Tese de Doutoramento), p.271.

68 Francisco Spadoni, op. cit., p.276.

69 Idem, ibidem, p.276.

70 Idem, ibidem, p.174. 

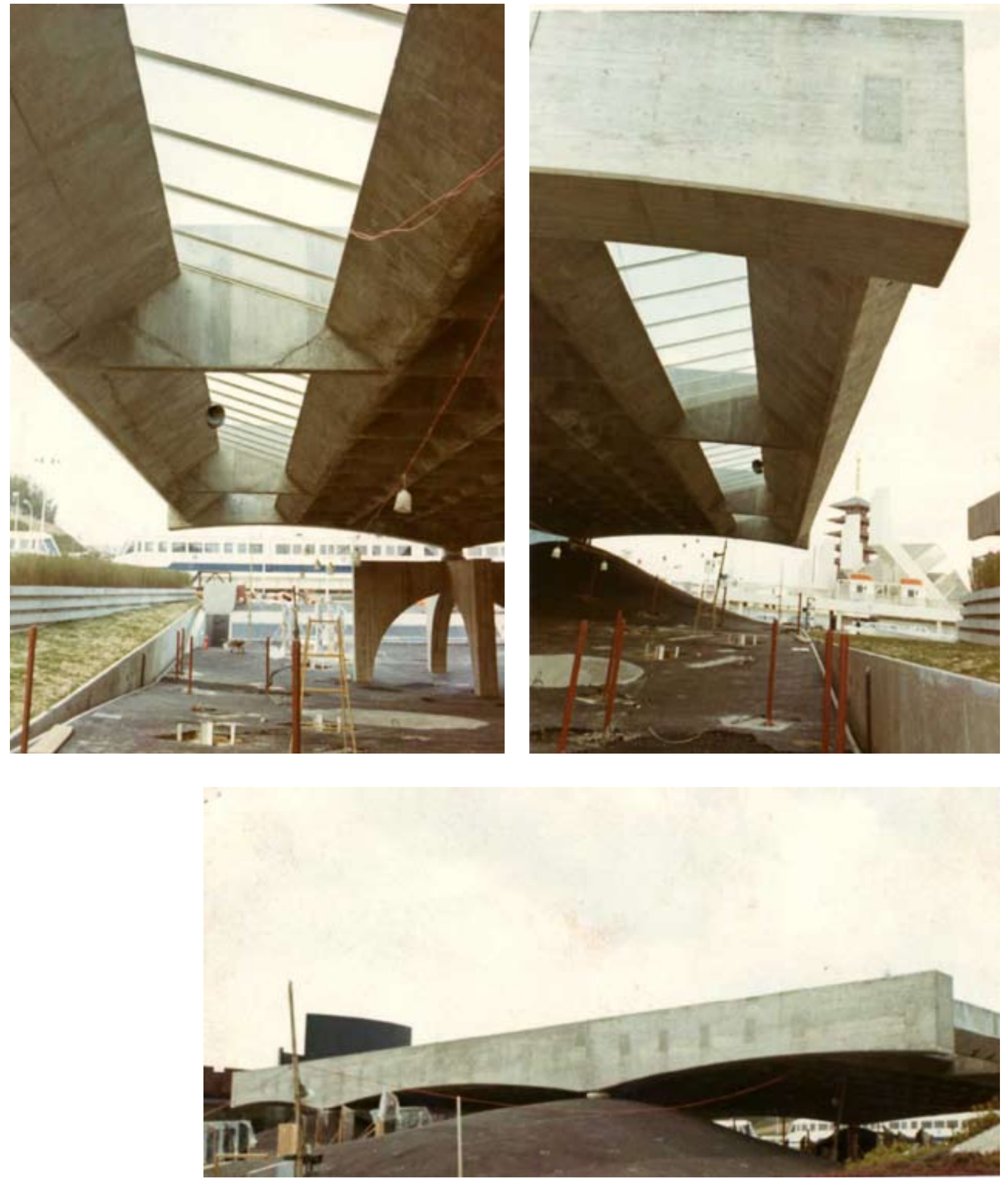
Neste quadro, Spadoni localiza o pavilhão como um episódio singular que dá início a este período, e preconiza um conjunto de dilemas que serão cruciais para o desdobramento da década:

"O pavilhão de Osaka assume-se como uma figura completa do ideário moderno brasileiro, pois pode espelhar suas duas versões mais significativas. Recupera soluções sedimentadas e simbólicas, como a cobertura e o grande vazio, e elabora um discurso técnico com os vãos. Mantém-se, no entanto (como não poderia deixar de ser), dentro da poética particular de um arquiteto de brilho próprio, com matiz equivalente ao de seus predecessores. $O$ desenvolvimento desse procedimento ao longo da década que se iniciava é que viria a sedimentar um repertório figurado dessa arquitetura, pois se disseminava em programas distintos - sobretudo na arquitetura bancária e doméstica - esse saber fazer que, de tão rarefeito, perdeu o vigor. ${ }^{n 1}$

Além do debate acerca do significado do Pavilhão como marco dentro da produção específica da linha "paulista", uma outra vertente de que o analisa o projeto do Pavilhão inserido no conjunto da obra de Paulo Mendes da Rocha, em textos críticos que acompanham as publicações de projetos no Brasil e no exterior e em alguns trabalhos acadêmicos que tratam especificamente de sua obra. O número de trabalhos sobre sua obra vem aumentando consideravelmente desde meados dos anos 90, e principalmente após o projeto de reforma da Pinacoteca do Estado ter ganho projeção internacional ao receber o prêmio Mies Van der Rohe para arquitetura Latino-americana em 2000, e Paulo Mendes da Rocha receber o prêmio Pritzker em 2006, o que o tornou alvo de uma série de artigos recentes em publicações nacionais e estrangeiras, e impulsionou a publicação de monografias e coletâneas de projetos.

De um modo geral os trabalhos monográficos são muito semelhantes em termos de recortes historiográficos, e notoriamente concentram-se nos mesmos projetos - há um certo conjunto de projetos que invariavelmente é apresentado ${ }^{72}$, em outras palavras, há um determinado conjunto de trabalhos - no qual se inclui o Pavilhão de Osaka - que são considerados as peças-chave, ou os exemplos principais para a compreensão do pensamento e da produção do arquiteto.

Um exemplo recente entre esses trabalhos é o número especial da revista $2 \mathrm{G}$ sobre Paulo Mendes da Rocha, que traz um ensaio do arquiteto Guilherme Wisnik ${ }^{73}$ acompanhando 
a apresentação de um conjunto de projetos recentes e uma entrevista com os colaboradores do arquiteto. Neste ensaio, Wisnik identifica alguns temas principais que, em sua opinião, sempre percorreram a produção do arquiteto, e relaciona alguns dos projetos a esses temas, criando aproximações que transcendem os recortes e as organizações dos projetos em ordem cronológica, que são o modelo de apresentação constante neste tipo de coletânea.

Neste recorte, o Pavilhão de Osaka é apresentado como um dos projetos em que a característica principal é justamente um "enfoque urbanístico", ou seja, projetos que procuram recompor metaforicamente a cidade dentro de seus lotes, estabelecendo relações com seu entorno que reforçam seu sentido urbano. Neste grupo, segundo o autor, estão também os projetos para o Ginásio do Clube Paulistano (1958), o MUBE (1988), a Biblioteca Pública do Rio de Janeiro (1984) e a Praça do Patriarca. Ao reconhecer essas aproximações, e principalmente, certas recorrências em projetos realizados ao longo de períodos tão distintos, Wisnik acaba chamando a atenção para uma coerência na produção do arquiteto, que se mantém a partir de uma postura de pesquisa constante, como se o arquiteto buscasse recuperar um certo ideário a cada projeto. E deste ponto de vista, reafirma um sentido contemporâneo de cada um desses projetos, à medida em que as questões fundamentais que os guiam não envelhecem, e permitem que sejam considerados à parte dos períodos específicos de sua realização.

No caso do Pavilhão, essa possibilidade é bastante enriquecedora de sua leitura, já que permite repensar uma série de associações imediatas entre decisões de projeto e circunstâncias específicas a cada período. Nesse sentido, se é possível reconhecer no projeto características que "sempre existiram" na obra de Paulo Mendes da Rocha e que se mantém íntegras de modo independente da condição imediata, pode-se relativizar as análises que, por exemplo, associam o projeto a uma resposta ao regime ditatorial, como é o caso do trabalho de Maria Isabel Villac ${ }^{74}$, que enxerga no fato do pavilhão "ser aberto para todos os lados", uma oposição direta a uma situação política de restrições.

O estudo empreendido por Villac, apresentado como a tese de doutorado "La Construcción de la mirada", a Universidade Politécnica da Cataluña no ano 2000, também analisa a trajetória de Paulo Mendes da Rocha. Em sua tese, a autora desenvolve uma análise do Pavilhão repleta de imagens abstratas e poéticas, a partir de algumas chaves de estudo que se baseiam em experiências sensoriais e referências filosóficas ${ }^{75}$. Concentra-se em discutir a relação da obra com a natureza e sua representação, o caráter sintético da construção e o

74 Maria Isabel Villac, La construcción de la mirada : naturaleza, discurso y ciudad en la arquitectura de Paulo Mendes da Rocha. Barcelona, 2000, p.120.

75 Idem, ibidem, p.118-131. 
modo como se apropria do lote como um "território". Assim, detém-se especialmente no pilar em arco e seu significado simbólico:

"O pilar revela que a universalidade do pensamento é um elemento que domina a paisagem, embora esteja acolhido e reconciliado com ela, dominado por ela. Por estar na natureza e só por isso, a razão configura uma relação de igualdade e diferença entre o saber erudito e a experiência da circunstância. [...] Na paisagem contínua, de profundidade "infinita", o pilar estabelece a ordem construtiva - a outra face, um complemento à natureza -, a referência humana como valor de lugar - encontro- e como valor de marco - escala. O pilar se opõe a naturalidade da superfície, e se define, por sua artificialidade duas vezes confirmada, expondo sua dimensão corporal e fundadora, emoldurando, no interior dos arcos, um espaço de vocação humana que se irradia nas quatro direções cardeais." 76

Além disso, a autora é uma das poucas que considera em sua análise, ainda que sucintamente, a Exposição proposta para o pavilhão. Para ela, a Exposição traria uma possibilidade de resposta no plano político: se é possível supor que um país sob um regime ditatorial numa exposição universal poderia causar um certo constrangimento, por outro lado, a Exposição permitia "afirmar negativamente" a realidade repressora, marcar posição através da "ilustração da inteligência brasileira"77. Para ela, através da mostra o Pavilhão do Brasil também manifestava sua oposição ao sistema político, respondendo ao tema mais geral da Expo70 com uma visão que aproximava a "articulação social" da "uma atividade criativa":

"A partir de uma proposição construtiva ampla, a temática reúne indústria e tecnologia, história e projeto. A projeção de um tempo contemporâneo, ancorada na evolução antropológica da história, expõe a necessidade de expansão do território habitável. Articulado sobre os avanços da ciência, os sistemas de comunicação, e a reorganização e criação de novas cidades, o projeto da mostra pensa o "progresso" sob a ótica do trabalho e da contribuição não segregada de nativos e estrangeiros"78.

Assim, através de uma apresentação dos temas mais gerais presentes nos painéis, a autora percebe sua relação com algumas das idéias principais do projeto do Pavilhão; sendo assim, é o único trabalho dentre os que analisamos que se preocupa em tentar reconhecer 
aproximações entre o projeto e a exposição, no sentido de uma complementaridade de discursos entre o projeto e a proposta de Flavio Motta:

"Quando esse historiador se pronuncia, está revelando que a configuração do projeto apresenta a hipótese da integração do Brasil a um mundo mais aberto, igualitário, socializado. O pavilhão tem, portanto, como compromisso, criar um espaço social amplo considerado no tempo histórico"79

Por fim, dentre os estudos acerca da produção de Paulo Mendes da Rocha, é especialmente significativo o trabalho desenvolvido por Sophia da Silva Telles ao longo dos últimos anos. Entre 1989 e 1991, junto à Faculdade de Arquitetura da PUC de Campinas, Sophia empreendeu uma vasta compilação dos artigos publicados sobre os arquitetos Paulo Mendes da Rocha, Joaquim Guedes e Lina Bo Bardi. Como ressalta a pesquisadora Catherine Otondo80, que vem se dedicando recentemente ao estudo da obra de Paulo Mendes da Rocha, este trabalho teve enorme importância num período de escassez de publicações específicas, e foi de grande serventia a uma série de pesquisas acadêmicas, permanecendo durante um longo período como a mais completa fonte de documentação disponível sobre estes arquitetos.

Num artigo específico publicado no caderno especial sobre Paulo Mendes da Rocha na revista AU em 1995¹, ainda que não se refira especificamente ao Pavilhão de Osaka mas sim ao conjunto da obra do arquiteto, Sophia apresenta algumas considerações que são fundamentais para a compreensão do projeto do Pavilhão.

Para ela, a obra de Paulo Mendes da Rocha é resultado de um "processo de síntese" no qual todos os elementos do projeto tornam-se "cada um, o sentido de todos os outros". Nessa síntese, "os procedimentos não são reduções, mas condensações máximas das variáveis de um projeto em uma única situação, quase sempre exposta de uma só vez, no raciocínio do corte"82, que tem como operação central na obra de Paulo Mendes da Rocha uma

"atitude técnica: a manifestação do dispositivo inconsciente que preside o nosso desejo de transformar e inventar o nosso habitat., [...] vontade individual que carrega consigo todo o engenho humano, a história de suas formas e construções. [...] a

Idem, ibidem, p.121.

Catherine Othondo, Memorial de Qualificação, FAUUSP, 2009, p.46.

81 Sophia da Silva Telles. "A casa no Atlântico", AU / Arquitetura e Urbanismo, n60, 1995, pp. 70-72.

82 Sophia Telles, op. cit., p.70. 


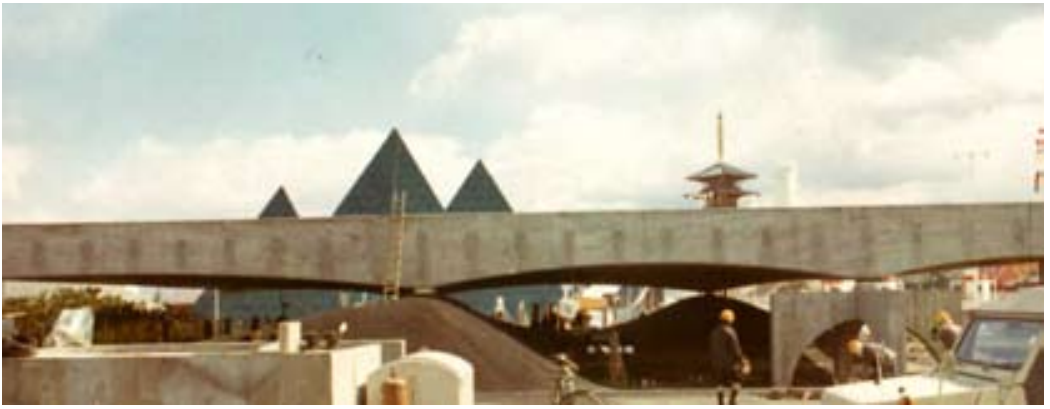

1. Vista a partir da rua "de trás" do Pavilhão onde passa o monorail. A esquerda vemos parte da escada de acesso ao Anexo do Itamaraty (ver versão final do projeto em anexo).

2. Vista aérea da Expo70. Em primeiro plano, Pavilhão da URSS, e a direita dele, o Pavilhão do Brasil.

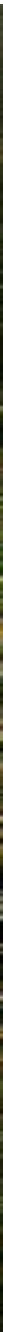


racionalidade construtiva nunca será uma simples função; ela terá sido sempre 'um discurso sobre nós mesmos" ${ }^{83}$.

Assim, para Sophia Telles, é possível identificar na obra de Paulo Mendes da Rocha um 'projeto' num sentido genérico, como um ideário recorrente. Neste projeto,

"a estrutura não se pensa como um puro desenho, atento ao detalhamento de suas articulações, como se fosse objeto armado no espaço. O projeto não é uma estrutura transparente, mas uma relação transparente entre dois planos paralelos: a projeção da cobertura - uma figura geométrica íntegra, estática portanto, e a linha solta de uma superfície em movimento. A chave de seu partido é a implantação, uma delicada operação de escalas que mantém uma proximidade quase física entre os dois planos: a construção e o terreno'84.

Essa definição do que seria um projeto "genérico" constantemente reelaborado na obra de Paulo Mendes da Rocha poderia ser lida como uma descrição do Pavilhão de Osaka. Nesse sentido, o Pavilhão representa um modelo de pensamento, um conjunto de questões recorrentes num sentido de na pesquisa individual de Paulo Mendes da Rocha. E ainda que as questões que norteiam essa pesquisa possam ser reconhecidas em outros trabalhos, seu rebatimento no Pavilhão é tão imediato que seu partido de confunde com esta proposição teórica.

Por esta razão, as leituras que analisam o pavilhão como de sua inserção numa linhagem "paulista" e sua representatividade como produto desta vertente, não são capazes de esgotar as possibilidades de compreensão desta obra. Assim, a tentativa de relacionar sua tipologia a um partido recorrente do grupo "paulista" (no caso, a cobertura única apoiada sobre quatro pilares), ou mesmo as discussões a respeito das continuidades ou desvirtuamentos desse movimento a partir do projeto do Pavilhão não são capazes de encerrar o interesse neste projeto, pois não totalizam seu sentido enquanto obra de arte e conhecimento. A interpretação do pavilhão ultrapassa a sua compreensão como exemplar característico da arquitetura brasileira ou de alguma de suas vertentes. Ao contrário, seu valor maior está nos elementos que transcendem esse modo de olhar, nesse sentido é que propomos entendê-lo a partir da coerência discursiva e poética que o articula ao projeto expositivo que pretende

83 Idem, Ibidem, p.71.

84 Idem, Ibidem, p.72. 
abrigar, assim como a partir da profunda relação intelectual que se estabelece entre Flavio Motta e Paulo Mendes da Rocha. Reconhecer como um discurso - o do projeto ou o da exposição - se alimenta do outro, o completa e dá sentido é, portanto, fundamental para o seu entendimento.

Do mesmo modo que a exposição, o texto de Flavio Motta escrito para a segunda apresentação do projeto na Acrópole ${ }^{85}$, alguns meses depois do concurso, traz também outros elementos para uma compreensão do Pavilhão num sentido mais abrangente. Como se fosse um desdobramento do sucinto memorial que havia sido apresentado na época do concurso, é esse texto o que mais esclarece o sentido pretendido no projeto. Neste segundo texto, logo no início, Flavio insere o projeto do pavilhão no "processo de desenvolvimento histórico da arquitetura brasileira", ressaltando o fato de que este processo teve início com o pavilhão de Nova York:

"não deixa de ser também significativo o fato de um outro pavilhão brasileiro-aquele realizado por Oscar Niemeyer, Lucio Costa e Paul L. Wiener para a Feira de New York, em 1938, ter sido o primeiro marco exterior da capacidade do Brasil em criar uma arquitetura moderna de reconhecido interesse universal. Desde então, Lucio Costa, Niemeyer e seus companheiros do Movimento da Arquitetura Moderna no Brasil, demonstraram um empenho poético de tamanha amplitude, de tão simples e generosa visão espacial, que acabaram por se confraternizar com os mais elaborados propósitos artísticos daqui e de outros países. "186

Em seguida, faz uma breve apresentação de algumas das principais realizações da arquitetura brasileira no contexto internacional desde então, protagonizadas por Lucio Costa e Oscar Niemeyer, passando pela sede da ONU, o edifício da UNESCO em Paris e a Casa do Brasil. Pontuando esta filiação, mais uma vez, Flavio Motta estabelece uma relação muito mais de continuidade da arquitetura carioca do que de oposição. No entanto, a possível contribuição brasileira ao panorama internacional refere-se não as manifestações próprias e peculiares, reconhecidas como características estritamente nacionais, mas sim à sua capacidade de corresponder aos propósitos humanos mais universais, num sentido de igualdade de condições, posto que "é também o resultado de uma visão moderna da vida urbana e do viver em geral do nosso tempo" ${ }^{87}$. Segundo a apresentação de Flavio, o que caracterizava o modo de projetar da arquitetura brasileira era um "denso sentido de síntese", que para poderia 
ser reconhecido através da "simplicidade e beleza" das obras. E essa capacidade sintética assumia a forma de um "procedimento" no fazer, no qual sobressaía uma "peculiar situação da inteligência artística: ela procurava se desembaraçar do supérfluo, e de tudo o que pudesse diminuir o esforço em ampliar e adensar as relações sociais." 88

No Pavilhão, tratava-se de "ir além" daquilo que seria uma expressão simplesmente brasileira, e, portanto, de confrontar a sua leitura como expressão de uma visão particular de mundo, nacional, regional ou de escola. O pavilhão deveria ser compreendido como "obra de arte universal", isto é, contemporânea, válida independentemente de sua origem nacional, aproximando-se, enquanto arquitetura, das "convicções básicas e também transcendentais de um viver humano socialmente afirmado" 89 . Assumindo essa possibilidade como pressuposto, fazia sentido pensar o pavilhão nacional a partir do referencial universal da Feira, como espaço de aproximação entre os países independentemente de suas hierarquias convencionais. Afinal de contas, o Pavilhão representava

"uma arquitetura em Osaka, projetada para Osaka, onde o homem do Brasil estaria presente de maneira íntegra, dentro desse íntimo e direto compromisso com os homens vindos de todo o mundo, presentes e trabalhando em Osaka". ${ }^{90}$

E para ele, esse "aprofundamento cultural" era tanto mais representativo quando se considerava a proximidade que se criara entre o Brasil e o Japão ao longo do século XX. 0 empenho do projeto remetia-se, portanto, também a um "esforço de comunicação com uma arquitetura que, produzida dentro da específica condição brasileira, também se mostrava possível, em Osaka, como aproximação humana de interesse universal." O projeto do pavilhão era possível porque compreensível a qualquer um, independentemente de se conhecer ou não o Brasil. Nesse sentido, o que se pretendia era justamente contrapor as representações exóticas do país, tão recorrentes nas exposições universais desde o século XIX. Não se propunha, pois, qualquer distanciamento cultural que remetesse o edifício ao pitoresco, ao regional ou ao folclórico ${ }^{91}$. 0 conhecimento necessário para se compreender as questões levantadas pelo pavilhão era o conhecimento humano de modo mais geral.

0 passado a que o projeto se remetia não podia ser restrito ao passado nacional, mas

\footnotetext{
Idem, Ibidem, p.25.

Idem, ibidem, p.26

Idem, ibidem, p.26.

91 Uma característica do pavilhão bastante particular, nesse sentido, é a ausência de um jardim. Presente em todas as representações brasileiras anteriores a de Osaka, a idéia de transpor uma parte da exuberância da flora tropical como demonstração da diversidade brasileira, no caso do pavilhão é substituída por uma paisagem no sentido oposto, simbólica, e que ao mesmo tempo, nos fala sobre uma idéia universal de paisagem e natureza.
} 
o ultrapassava, abarcando o esforço humano mais geral de conhecimento. Se por um lado o projeto do pavilhão não se furtava a mostrar as especificidades nacionais, ele também mantinha o sentido maior que se fazia presente na obra de arquitetura.

\subsection{A exposição de Flavio Motta para o pavilhão}

Quando a equipe coordenada por Paulo Mendes da Rocha foi contratada pelo governo brasileiro para o desenvolvimento do projeto vencedor, constava em seu escopo de trabalho a apresentação de uma proposta de exposição e o programa das atividades culturais que seriam apresentadas no Pavilhão durante o período da Expo70.

Em paralelo ao início das obras, Flavio Motta elaborou a proposta para o conteúdo do pavilhão, segundo Paulo Mendes da Rocha, escrita e desenhada de uma só vez, organizando os temas e as imagens de memória, como se a idéia já houvesse sido definida previamente ${ }^{92}$. Ainda que possa haver certo romantismo nessa evocação, e por mais que a experiência anterior com exposições didáticas viesse ao seu auxilio, parece-nos que os temas da exposição e seus conteúdos vinham sendo expressos ao longo da década de 1960 em todo um projeto coletivo, desenvolvido junto a um grupo de arquitetos ligados a Artigas entre os quais o próprio Paulo Mendes da Rocha. Esta é a idéia central que pretendemos discutir neste capítulo. Sendo assim, a análise do material produzido por Flavio Motta para a exposição é nosso principal objeto de estudo.

Não se sabe se havia alguma solicitação no edital do concurso quanto à realização de uma proposta de exposição, mas dentre o material que conhecemos a respeito dos outros projetos premiados ${ }^{93}$ há também, em alguns deles, indicações do que seria exibido em cada edifício proposto. Dos sete projetos apresentados, quatro deles, além do vencedor, mencionam em seus textos o que poderiam ser os seus conteúdos expositivos. Mesmo sendo bastante preliminares, talvez a solicitação, se é que havia, fosse justamente a de uma apresentação

92 Depoimento de Paulo Mendes da Rocha concedido à autora, em 16/10/09.

93 Publicados na revista Acropole, n.361,op.cit. Devido ao caráter sucinto do material publicado na revista, é possível supor que as equipes, no momento em que selecionaram o material para a publicação, editaram seus conteúdos e, neste caso, haviam deixado de mencionar o projeto do conteúdo do pavilhão. Entretanto, se este foi o ocorrido em alguns casos, pode-se concluir que as equipes que optaram por não mencionar a mostra decidiram que esta não era importante ou significativa para a compreensão do projeto. 
apenas esboçada. Mas de um modo geral, através desta amostra, pode-se observar duas tendências recorrentes, que se distanciam da idéia de exposição apresentada pela equipe vencedora.

A primeira delas é que a referência à exposição restrinja-se apenas a conteúdos que viessem a justificar ou requeressem espaços próprios no projeto arquitetônico. Em outras palavras, uma tendência expositiva inteiramente submetida às determinações do próprio projeto, onde não se reconhece uma intenção clara em eleger conteúdos para a exposição como se ela servisse tão somente ao propósito de definir ou setorizar os espaços nos projetos de pavilhão. É esta aliás outra diferença em relação ao projeto arquitetônico vencedor, onde os espaços propostos não tem funções e percursos rígidos, como tal não se arriscando perder o seu sentido se a mostra não fosse realizada, como de resto foi o caso.

0 melhor exemplo dessa postura é um dos projetos que recebeu o $4^{\circ}$ prêmio, da equipe coordenada por Artur Lício Pontual. Nele, a equipe apresenta sua proposta apoiada explicitamente na idéia de "uma perfeita integração entre a mostra e os aspectos arquitetônicos internos ou externos", na qual o pavilhão praticamente se transforma em uma cenografia, em uma "embalagem" para usar a expressão do próprio Flavio Motta. O fato é que os arquitetos explicam claramento quais os elementos que deveriam compor o cenário pensado - "projetores, espelhos, telas" - sem qualquer preocupação em descrever os conteúdos da mostra.

A outra tendência que pode ser observada entre os projetos premiados é a de uma certa tendência a uma visão da cultura brasileira partindo de estereótipos e clichês, o que causa uma certa estranheza se pensarmos que os arquitetos brasileiros representavam há muito tempo posições de vanguarda e engajamento no campo cultural. É possível constatar em todos os projetos que sugerem uma programação para o pavilhão, uma visão do país que mistura manifestações culturais contemporâneas com as imagens dos trópicos, da "miscigenação das raças" ou do caráter nacional, características de um discurso conservador ou exoticizante, que nos remete diretamente aos pavilhões do final do século XIX, quando países como o Brasil compareciam nas feiras internacionais para frequentemente figurar o pitoresco.

Um exemplo é a equipe coordenada por Siegbert Zanetini, que propõe uma escola de samba que recepcione os visitantes na entrada e percorra com o público o espaço do pavilhão, no qual estará sendo servido caipirinha, feijoada e churrasco. Outro exemplo aparece também no projeto de Artur Lício Pontual, que organiza a mostra [e também o edifício] através dos núcleos "a terra", "o homem" e "a cultura", propondo uma mostra de objetos brasileiros primitivos junto aos novos objetos de desenho industrial. Já o projeto classificado em segundo lugar no concurso apresenta a proposta de exibir "o espírito do povo brasileiro nas suas mais representativas formas de expressão: música, dança, folclore, teatro, cinema e artes 
plásticas, assim como as grandes manifestações de massa, como o carnaval, o futebol e toda a espontaneidade do povo". A apresentação feita pela equipe de Edgar Dente, um pouco mais intrigante, apresenta um memorial na forma de um poema, no qual aparecem a "mulata de Caymi”, o samba, Pelé, Caetano e Chico ao lado de Oscar Niemeyer e Villa-Lobos.

Como no caso dos outros projetos concorrentes, o pavilhão vencedor também havia feito, durante o concurso, uma proposta preliminar de conteúdos que poderiam fazer parte dessa programação, e que foi incluída no memorial descritivo apresentado na ocasião. Escrita por Flavio Motta, quando foi desenvolvida em sua versão definitiva, de certo modo, a exposição manteve os eixos dessa organização inicial:

"A exposição se organiza assim:

1. História e Projeto:

Brasília

Novas cidades. Negev - Argel - Gras

Cidades em transformação - Novo Rio, Nova São Paulo...

2. Indústria - História e Projeto:

Índio escravo (Debret)

Índio como homem

Imigrantes (Portinari, Segall)

Belém-Brasília

Ligação Amazônia-Prata

Itaboraí - TV

Plano brasileiro para o desenvolvimento da ciência

3. Espetáculos:

Serão organizados, para o tempo que durar a Expo 70, apresentações de música, teatro, cinema, mostras de artistas plásticos, dança e toda manifestação de cultura - contribuição a esse encontro que desejamos."

Nos parece que este é um ponto de partida significativo: ainda que só tenha sido detalhada na segunda etapa de projeto, o pavilhão já nasceu atrelado a uma idéia de seu conteúdo, em outras palavras, a idéia do projeto sempre esteve ligada a um diálogo entre a obra arquitetônica e um conteúdo que ela trazia. Ao contrário dos outros projetos premiados, o que se apresenta sobre a exposição são seus temas [as novas cidades, o processo de urbanização, a ocupação do território, o desenvolvimento científico, o trabalho] e não o modo como se organiza no espaço. O que interessa é a narrativa, e neste caso trata-se de uma narrativa própria, na qual a equipe vencedora do concurso não apresentava simplesmente um 
projeto, mas um discurso sobre a arquitetura e o Brasil.

Do mesmo modo, ao contrário das outras equipes, esse discurso teria bastante independência em relação ao espaço proposto. Assim como o projeto do pavilhão não precisava da organização da exposição para sustentar as suas características principais, a exposição também tinha sua autonomia, até porque partia de uma matriz de pensamento comum ao projeto do edifício e não se afirmava com base em um projeto expográfico rígido mas era concebido a partir de seus conteúdos e de suas relações recíprocas. Ou seja, porque edifício e exposição se complementavam de um modo muito particular, um fornecendo elementos para o entendimento do outro.

A equipe deveria apresentar ao governo brasileiro um programa de atividades, incluindo também o conteúdo dos painéis expositivos. Flavio Motta desenhou então um rascunho desse programa, composto por 37 folhas formato A2, com desenhos e textos, intitulado "Plano básico para os trabalhos complementares do pavilhão do Brasil"94. Nesse conjunto estão os textos explicativos acerca do conteúdo da programação, os projetos dos painéis propriamente ditos, e as propostas dos eventos que poderiam ocorrer simultaneamente à exposição, durante o período da Expo'70. A partir desse rascunho, a equipe produziu sua versão definitiva, cujo conteúdo é exatamente o mesmo e no lugar dos desenhos de Flavio Motta aparecem as fotografias das obras e objetos, e o texto, antes escrito à mão, foi carimbado nas pranchas. Para esta versão, os artistas Carmela Gross e Marcelo Nitsche percorreram os museus e as instituições e fotografaram as obras que Flavio Motta havia desenhado, que foram utilizadas na composição de negativos fotográficos afixados no caderno com as pranchas definitivas,

Enquanto esteve no Japão para a realização do projeto executivo, Paulo Mendes da Rocha teve contato com uma empresa de tecnologia que acabara de desenvolver uma máquina capaz de imprimir e reproduzir imagens com uma precisão jamais vista, e que estava sendo oferecida aos países participantes da Expo como uma alternativa a ser usada para realizar os trabalhos impressos relativos à sua participação. Quando regressou ao Brasil, em junho de 1969, apresentou essa possibilidade a Flavio Motta e à equipe, que prontamente consideraram utilizá-la para realizar os próprios painéis da exposição.

Não se tratava, portanto, de uma exposição de originais. 0 que interessava não era propriamente o valor das obras em si como "obras-de-arte", mas a narrativa que se tecia na relação entre as imagens. Em paralelo à exposição, a equipe também propunha a impressão de posters que poderiam ser vendidos como souvenires aos visitantes, impressos na mesma máquina que os painéis a serem expostos, sendo assim reproduções exatas do conteúdo da 

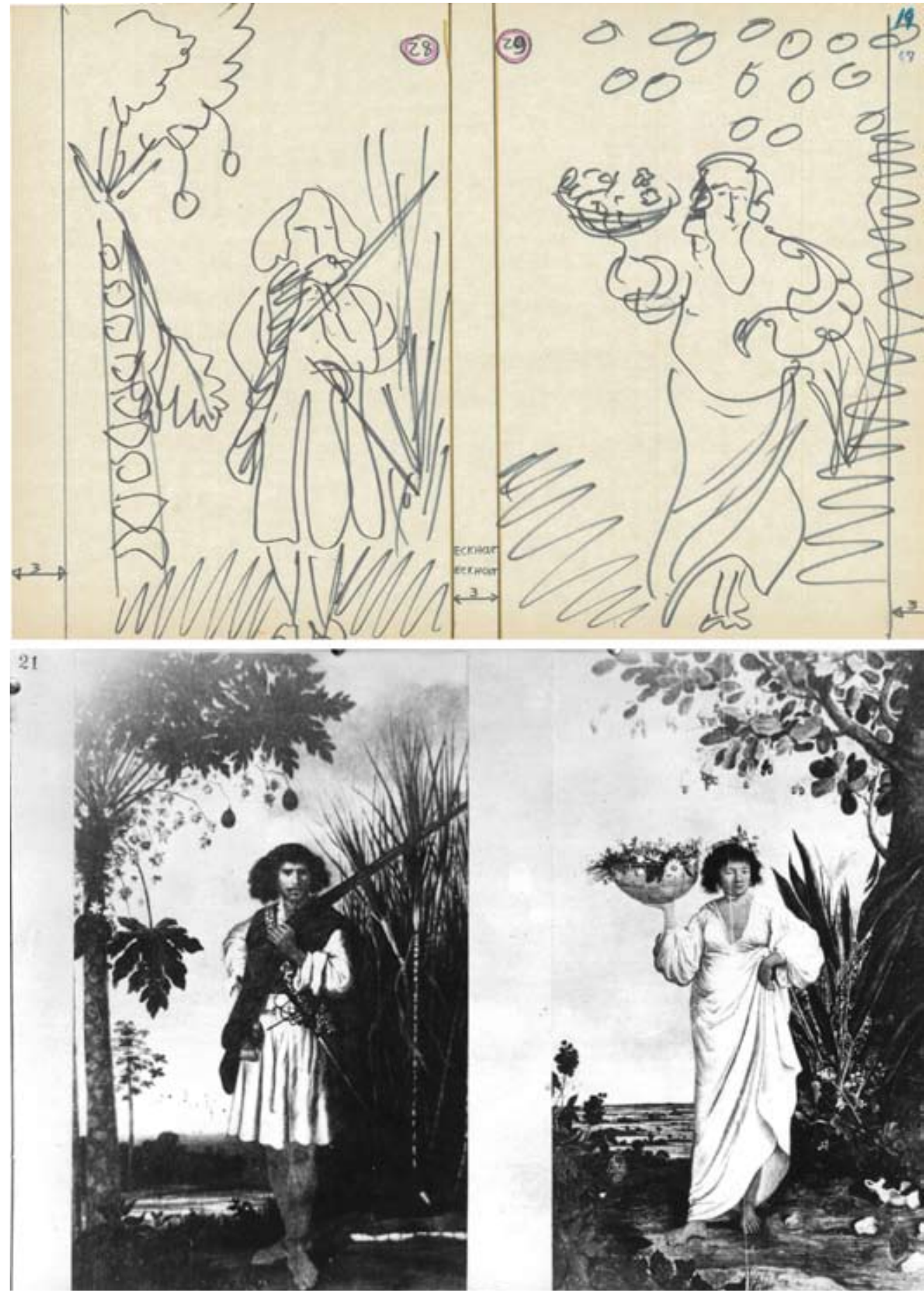

Exposição projetada para o Pavilhão

1 a 10. Comparação entre os estudos de Flavio Motta para os painéis e os painéis fotográficos que a equipe confeccionou para a apresentação, nais quais se nota a precisão dos desenhos (realizados "de memória") em relação às obras originais. 

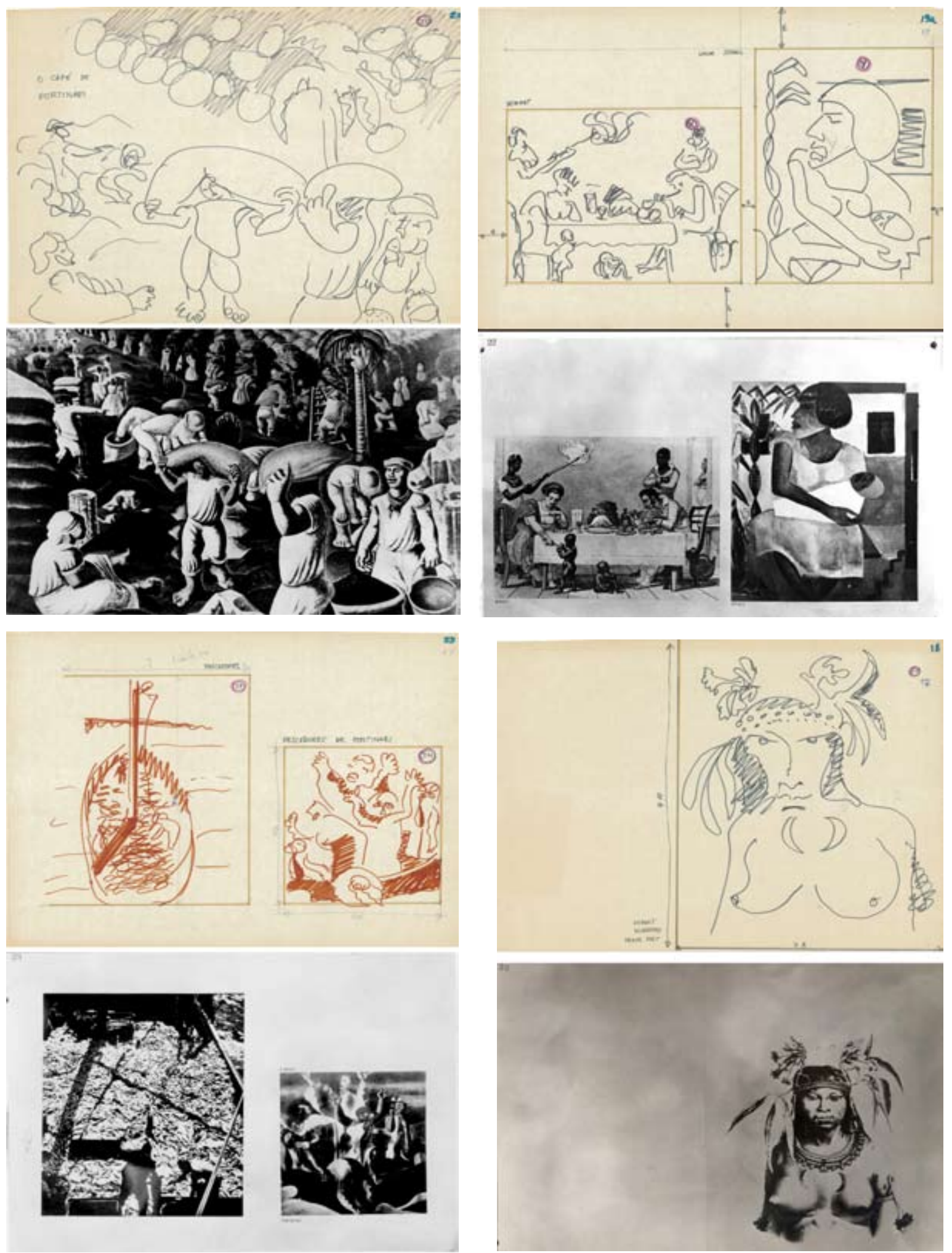
exposição, e com a mesma qualidade de impressão. Desse modo, o visitante poderia levar consigo a exposição, idêntica àquela que havia visto no pavilhão.

Esse despojamento, que privilegia o discurso mais do que a obra em si, remete-nos diretamente aos programas educativos em que Flavio Motta atuou em seus anos de formação, especialmente à Exposição Didática do MASP, na qual iniciou sua aproximação ao ensino de história da arte, também composta a partir de um discurso narrado por meio de reproduções.

Mas olhemos diretamente o conteúdo das pranchas. Talvez seja possível compreender esse discurso a medida em que reunirmos de modo mais esquemático o conteúdo da sequência dos painéis e os temas mencionados no projeto. 0 tema geral apresentado na proposta é o "projeto da cidade". É a partir da cidade que se revelam todas as esferas de que trata a proposta. É através dela que é possível entender o que é o desenvolvimento na modernidade do Brasil. Assim, logo de início se apresenta o projeto:

"O Brasil comparecerá em Osaka com uma contribuição própria ao viver contemporâneo, procurando alinhar-se a uma visão de conjunto, de harmonia, com outros países presentes à mostra. Exibirá um projeto para o seu desenvolvimento, uma visão de 'habitat' contemporâneo, fruto da riqueza e do avanço da humanidade. - cidade como forma de viver - urbanização como fenômeno social - o desejo do homem moderno, qual seja: a convivência no trabalho, na pesquisa científica, na indústria e na arte. É desejável também que se conte desse povo a experiência, que não Ihe é privilégio, mas o faz na história, aliado de todos os outros povos. Assim se chega à cidade pela história',95.

O tema do projeto da cidade se desdobra em outros dois:

1. "a visão no Brasil do desenvolvimento a partir da cidade moderna"96

A primeira cidade que o projeto da exposição mostra, através da qual se pretende apresentar um exemplo particular de desenvolvimento na história, é o Rio de Janeiro, "desde os caminhos primeiros até aqueles que, por extremo contraste, levam ao projeto de Jacarepaguá". Além do Rio de Janeiro, haveria ainda "o sentido interiorano de Brasília com suas estradas" e "a posição do pensamento brasileiro, em harmonia com um outro desejo universal - visto no projeto para um deserto - o plano de Neguev"97. 
1. estudo de lay-out para a exposição no pavilhão, mostrando os painéis contínuos e as esculturas soltas no espaço.

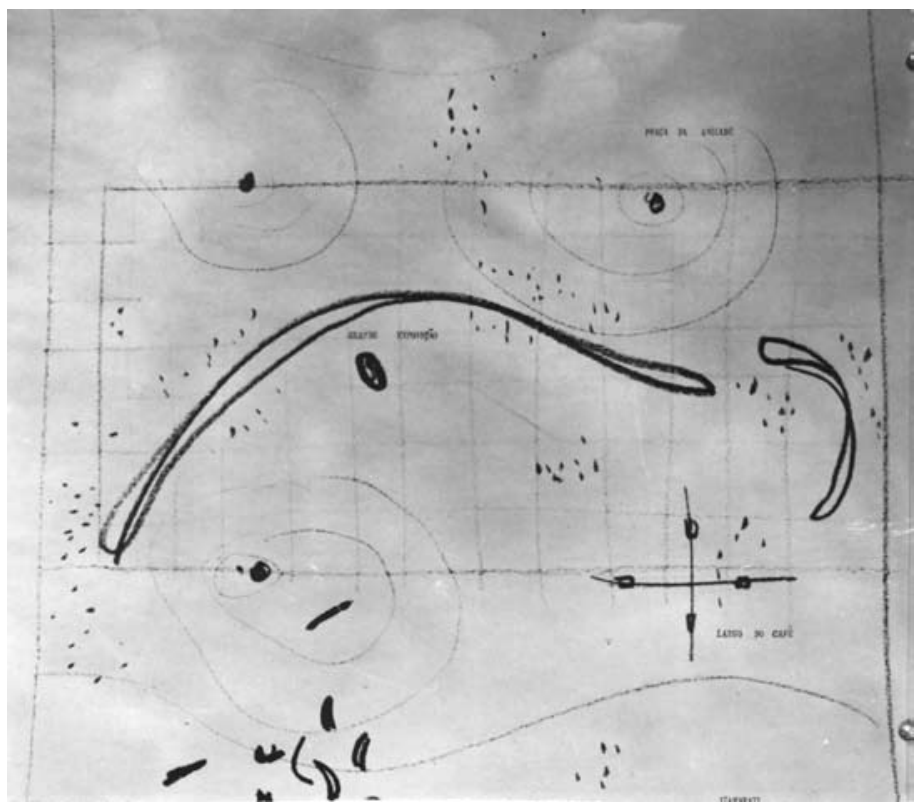

O tema central nesta primeira parte da exposição é a urbanização como processo de ocupação do território, e em particular, do território americano. Pretende-se mostrar ao público estrangeiro quais são as nossas questões em relação ao território, de que modo essas questões sugerem projetos, e como esse modo de agir através de projetos corresponde a uma contribuição particular ao conhecimento.

Assim, a exposição mostra um percurso dessa ocupação que tem como referência inicial os índios, e o modo como estabelecem "uma situação de convivência e defesa de sua cultura, que constituiu um viver singular em confronto com o humanismo europeu, na mesma época dos projetos de cidade de Filarete e Da Vinci" ${ }^{98}$. Com este painel, a exposição propõe uma visão do encontro entre a cultura indígena e os povos europeus, a partir de modos diferentes de ocupar o território, apresentando imagens de artistas que retratam a configuração espacial das aglomerações indígenas (Hans Staden, Frans Post), e ressaltando, neste discurso aos estrangeiros, que no mesmo momento em que na Europa o arquiteto florentino Filarete pensava o plano de uma cidade ideal do Renascimento, os índios americanos estavam estabelecidos em suas formas de organização peculiares. Nesse sentido, partimos de um olhar sobre o 
território que leva em conta esse encontro ou embate.

Outra questão fundamental que está no centro da idéia de ocupação do território é uma relação muito particular com a natureza, que também aparece nos primeiros painéis. Flavio Motta apresenta uma visão da natureza que é associada a uma idéia de monumentalidade, que ele explica através de Lucio Costa: "aquilo que respeitamos comovidos, não o que nos atordôa"99, uma monumentalidade que, segundo ele, responde aos "amplos interesses da vida coletiva". Como ilustração dessa idéia, ele propõe duas vistas do Rio de Janeiro a partir do mar, uma da cidade antiga e a outra do projeto de Lucio Costa para Jacarepaguá. O projeto de Jacarepaguá é ainda apresentado de modo mais detalhado, pois justamente é o ponto de chegada dos "caminhos primeiros" mencionados anteriormente.

Nesta relação entre projeto e natureza desponta o desejo de "abrir caminhos", "vencer distâncias de toda ordem", de aproximar as relações, promover encontros, e promover contato humano a partir do estabelecimento das cidades, "cidades para novos caminhos". Note-se nas imagens a presença de referências mais gerais que remetem ao sentido da cidade como lugar de encontro: a praça, a feira, etc. E junto a ela, Brasília, como "um sinal, um encontro", na referência rodoviária ao cruzamento dos eixos, que justifica o estabelecimento: "a cidade busca contato humano, desenvolvimento econômico. Deslocando a capital para o interior do país, cria as condições para uma nova forma de trabalho e circulação da riqueza" ${ }^{100}$.

0 discurso da cidade como lugar do encontro, da circulação e do desenvolvimento na referência aos caminhos que se cruzam conduz ao arco: "o arco assinala, com os elementos da arquitetura, novas possibilidades do encontro de pessoas na cidade". Ele é ilustrado pela perspectiva de Oscar Niemeyer para Neguev, com as arcadas de uma praça ${ }^{101}$, seguida das arcadas de um engenho colonial e de uma casa suburbana, pintadas por Franz Post e Alfredo Volpi respectivamente, e finalmente pelos arcos cruzados projetados por Paulo Mendes da Rocha para a Praça do Café no Pavilhão. Nesse sentido, a narrativa visual insere o pavilhão neste percurso histórico que trata da ocupação do território.

0 projeto de Neguev é apresentado no sentido de mostrar "a posição do pensamento brasileiro, em harmonia com um outro desejo universal - visto no projeto para um deserto - 0 plano de Neguev"102. Um outro tema que aparece nesse primeiro recorte é o do desenvolvimento das cidades, "compreendido como o vencer distâncias de toda ordem: geográficas, físicas, raciais, sociais, psicológicas, econômicas, históricas..."103. Dois projetos que aproximam 
distâncias, de caráter distintos, são então apresentados: o satélite Itaboraí e a rodovia BelémBrasília. E além deles, tem início uma seqüência de reproduções de obras de arte: "será possível compreender que o esforço de desenvolvimento, em toda a história brasileira, contou com o trabalho do índio da terra, do negro da áfrica, do imigrante europeu e asiático", trabalho figurado em obras que de modo geral retratam diferentes grupos em situações de trabalho. Ao mesmo tempo, em alguns painéis, ele aproxima imagens consagradas da história da arte com fotos de algumas cenas contemporâneas que remetem ao "desenvolvimento pelo trabalho", como no painel 25, onde estão lado a lado uma natureza morta de Eckhout e uma foto da Central de Abastecimento do Ceasa em São Paulo.

2. "a convivência no trabalho: econômico-social / científico / artístico".

Os temas que aparecem neste segundo bloco de assuntos propostos na mostra remetem ao desenvolvimento tecnológico e aos avanços técnicos e científicos do país, demonstrados através da apresentação de uma série de projetos que, partindo de áreas distintas, apresentam aos estrangeiros uma visão de desenvolvimento tecnológico também muito particular.

O primeiro desses projetos é uma idéia muito cara aos engenheiros, de uma interligação entre as bacias do Rio da Prata e do Amazonas, cortando o interior do continente e abrindo uma "nova costa", que transformaria as relações econômicas internas e também internacionais. Essa solução representava um

"projeto de grande envergadura, afirmação da capacidade de utilização dos mais avançados recursos técnicos, abre ao país uma segunda costa sobre uma paisagem rica em todos os aspectos da produtividade nacional.demonstra que o país se afirma com amplas propostas, em relação ao comércio e ao investimento. Põe a descoberto vários setores de atividade - comunicação, planejamento, saúde, agricultura, energia atômica - e consolida as noções das possibilidades de uma relação humanística no trabalho. A diversificação da estrutura industrial se amplia visando setores de bens de produção (químico, metalúrgico, máquinas e equipamentos) exige obras dessa amplitude. Coloca as reservas de matérias primas e a possibilidade de distribuição do produto mais acessíveis, numa escala humana e brasileira, em comunicação direta com os portos de mar. Liga os principais centros mundiais, diretamente, à área continental do país. Este projeto concretiza uma forma de "projetar" a industrialização, até agora insulada no centro-sul litorâneo, levando-a para o interior. Ampliará e tornará solidário o espaço econômico"104.

104 Idem, ibidem, painel nº 30. 


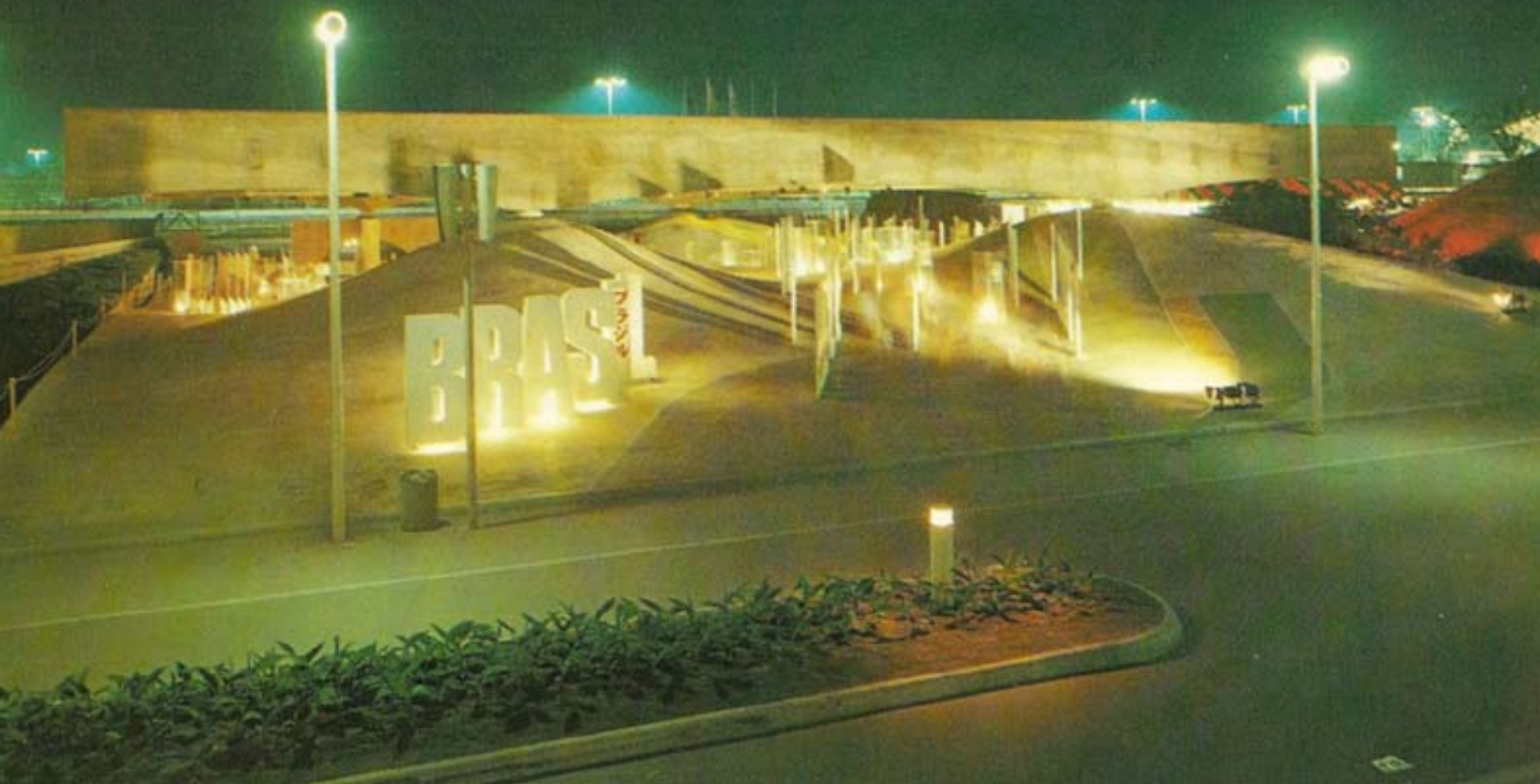

1. Vista externa da exposição que foi realizada pelo Itamaraty no lugar daquela proposta por Flavio Motta e a equipe. É possível perceber nesta imagem o piso de asfalto pintado com as faixas "verde e amarela" que indicavam o percurso a ser feito no Pavilhão.

2. Vista interna da exposição realizada.

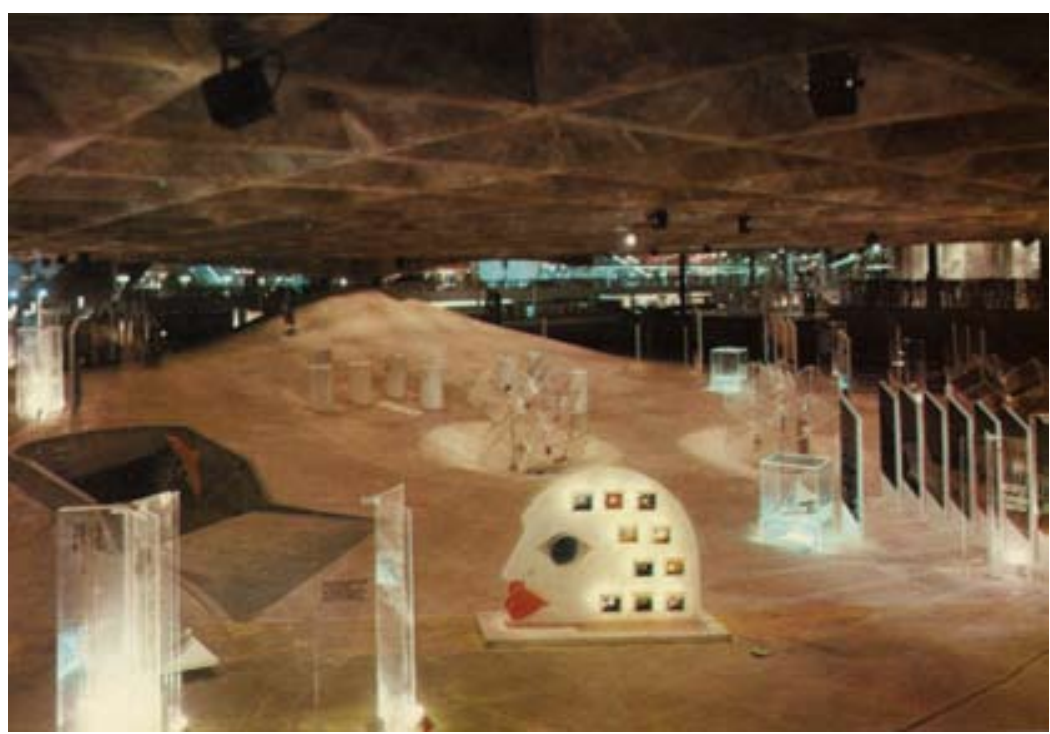


Num contexto de uma feira internacional na qual os países estavam disputando a liderança no desenvolvimento tecnológico, ostentando uma imagem "high-tech" em seus pavilhões, no auge da corrida espacial, o projeto que pretendia demonstrar a situação do desenvolvimento tecnológico brasileiro tinha, acima de tudo, um sentido humanístico de racionalização da natureza através da ciência, da técnica e do trabalho. "Trabalho cientifico criador" a demonstrar "que a ciência floresce com a cidade, na universidade, na indústria, e responde a todo um esforço de construção da vida moderna". A proposta sugere que a mostra inclua a "bola de fogo", projeto de cooperação entre brasileiros e japoneses coordenado por Cesar Lattes que descobriu as partículas atômicas méson-pi, em um dos painéis: "é a demonstração, também, das equivalências entre cálculo, experiência e a perspectiva científica, fruto de uma nova visão do universo. Assinala ainda como o trabalho científico criou novas situações de criatividade"105.

Junto à proposta da integração dos rios, havia também a idéia de apresentar no Pavilhão um modelo em escala de um navio, voltado especialmente à navegação no Rio São Francisco - "projeto de produto e maquinário que assinala a preocupação com o avanço tecnológico apropriado às condições do país [...] é um exemplo de beleza e consciência da significação dos produtos industrializados".

O programa de atividades proposto foi recusado pelo Itamaraty, que em seu lugar, contratou uma empresa que montou a exposição que efetivamente foi realizada. Para Paulo Mendes da Rocha, a recusa da exposição inicial era, evidentemente, uma decorrência das intenções do governo militar, mais interessado em reafirmar certos estereótipos do país, que não comprometessem uma imagem de desenvolvimento e crescimento econômico, aliados a uma convivência pacífica da população composta por "imigrantes de todas as raças"106 em harmonia. Através do catálogo da exposição que foi realizada podemos atestar o caráter descrito por Paulo Mendes da Rocha no depoimento a seguir:

"Bloquearam o propósito da mostra interna, que era justamente o ensaio sobre a idéia da consciência, sobre ocupação dos espaços na América pela civilização de um modo geral, e coisas do tipo. Para nós, [o Pavilhão] não era uma intenção de confronto, era simplesmente um exercício da liberdade. Eles praticamente interditaram o Pavilhão [...] mandaram contratar uma empresa para fazer uma exposiçãozinha mambembe como sempre se fez, de "berimbau", "rede" e "tendas de índios", essas coisas." 107

105 Idem, ibidem, painel n.14.

106 Segundo descreve o Catálogo da exposição realizada.

107 Entrevista de Paulo Mendes da Rocha à Andrea Macadar, em julho de 2004, publicada no portal Vitruvius em maio de 2006. <http://www.vitruvius.com.br/entrevista/mendesrocha/mendesrocha.asp> 
Além da mostra, a programação que Flavio Motta propunha para acontecer ao longo da Expo combinava diversas frentes. Uma delas propunha a realização de exposições coletivas que se alternariam durante o período de programação com alguns dos artistas mais importantes do período: Pisa, Antonio Dias, Wesley Duke Lee, Antonio Henrique Amaral, Manabu Mabe, Carlos Vergara, Hélio Oiticica, José Rezende, Maria Bonomi, Franz Waissmann, Marcelo Nitsche, Nelson Leirner, entre outros]. Estava programada também exposição de três escultores: Lygia Clark, Bruno Giorgi e Mario Cravo, que alternariam mostras individuais junto à Praça do Café. Por fim, era proposta também uma exposição de projetos de paisagismo de Burle Marx.

Além disso estavam programadas apresentações musicais e um ciclo de cinema. Flavio propunha que se realizasse uma série de espetáculos ao vivo, "desde as escolas de samba à "música de pesquisa'" e que a programação musical ficasse sob responsabilidade do Museu da Imagem e do Som. Já para a programação de cinema, ele indicava que fosse organizada pela Cinemateca Brasileira, e contasse com a assessoria de Almeida Salles, Paulo Emílio Salles Gomes e Joaquim Pedro de Andrade.

Haveria também uma exposição de fotografias, com trabalho de José Medeiros, Marcel Gautherot, Pierre Verger, Fulvio Reuter e Emil Schultheiss, e por último, pretendia-se programar uma série de publicações, "dentro de um plano de normalização que thes assegure qualidade gráfica e racional divulgação".

Essa programa abrangente, que reuniria nessas atividades algumas das figuras mais atuantes do campo da cultura no país, nos remete a uma posição de Flavio Motta como agregador de colaboradores e instituições, no sentido de inserir o projeto para o Pavilhão de Osaka num projeto coletivo, engajado na construção do conhecimento e da cultura. A reunião de todos esses artistas e intelectuais em torno do pavilhão, não tem o sentido da "apresentação de um panorama", como uma colagem de obras, filmes, músicas. Ao contrário, sua abrangência nada tem de superficial, ela nos dá a dimensão da coletividade, do "ver que vem de muitos"108, e remete aos conceitos presentes no próprio edifício do pavilhão. Compreender o pavilhão junto a esta programação traz a possibilidade de transformar as referências que são recorrentes nos discursos dos arquitetos - a geografia, o território, a inserção do projeto na história - em imagens concretas, em uma narrativa coerente, que insere o projeto em seu tempo, e simultaneamente, em um projeto maior.

108 Flavio Motta, "O olho", Textos Informes, op. cit., p.48. 
"Desde a conformação do piso até a cobertura, todo o funcionamento do pavilhão pressupõe um ritmo de relacionamento com sentido próprio, isto é, várias faixas de informação e comunicação de densidades diferentes, como se fossem planos harmônicos que fazem valer cada parte ou o todo simultânea e sucessivamente. O freqüentador do pavilhão perceberá essas relações sem perder a nitidez dos elementos visuais, espaciais, auditivos e mesmo de seus companheiros de caminhada." 109

109 Flavio Motta, op. cit., painel n 37. 


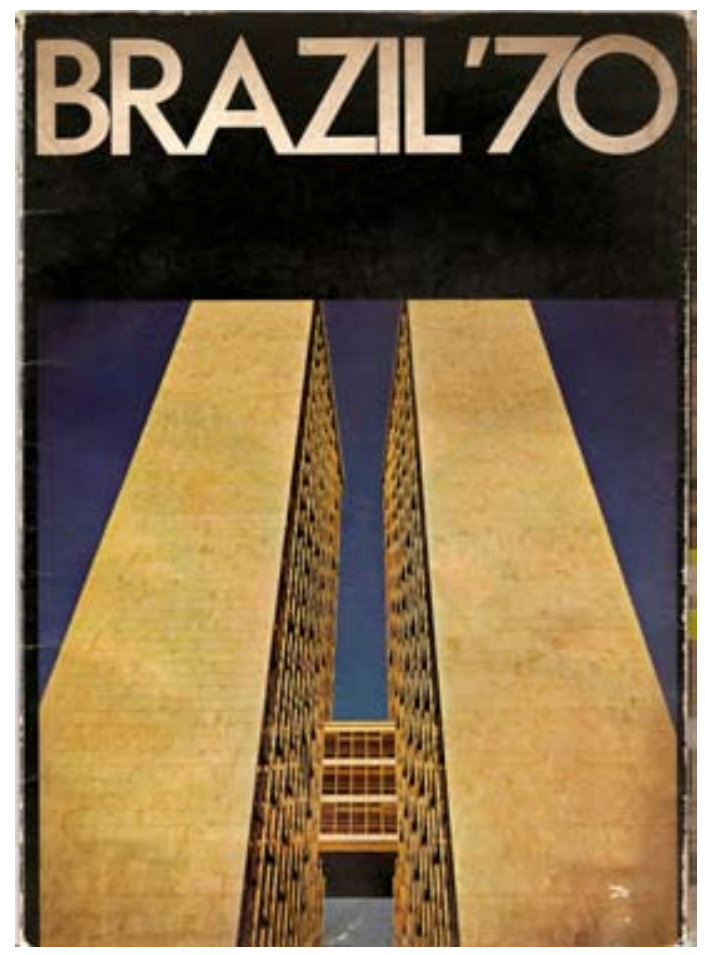

1. Capa do catálogo da exposição realizado pelo Itamaraty.

2, 3 e 4. Páginas internas do catálogo do Itamaraty.

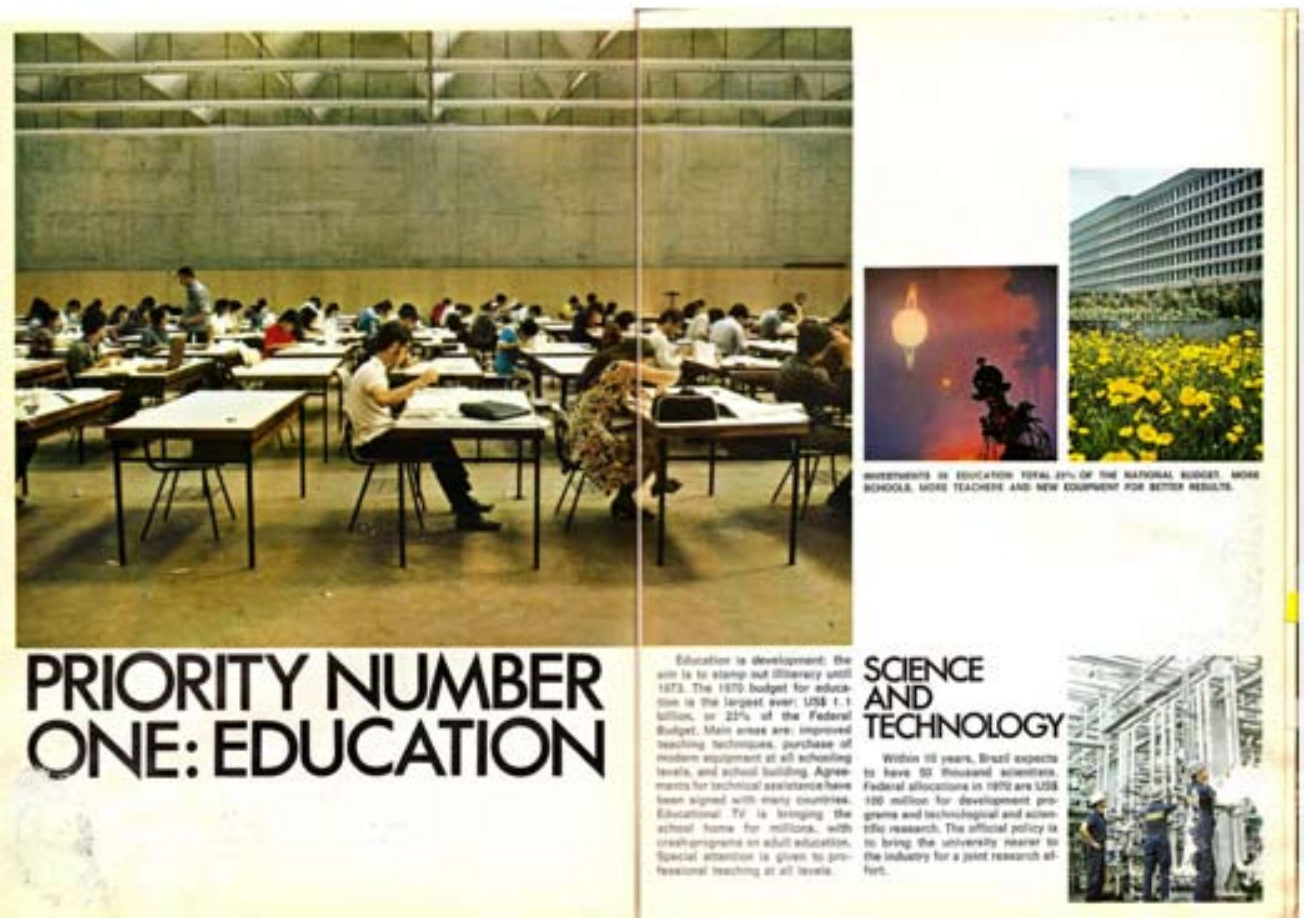



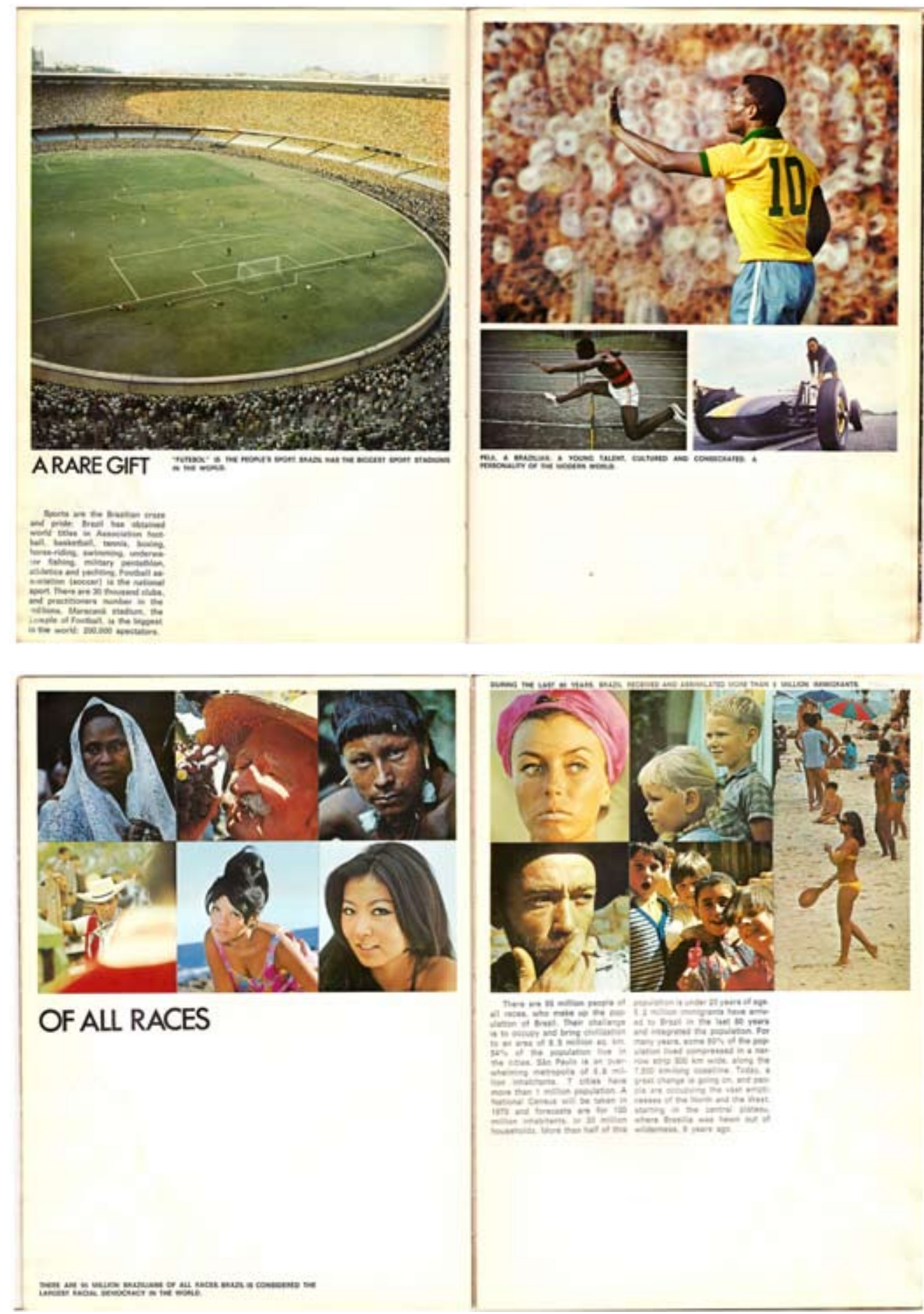



\section{considerações finais}

Os dez anos que separam o artigo Introduzione al Brasile da exposição para o Pavilhão de Osaka correspondem a uma intensa movimentação cultural no país. A década de 60 foi sem dúvida um período crucial na cultura nacional, que se por um lado se definiu a partir de uma produção inquietante e abrangente, por outro, sofreu a desagregação e os descompassos resultantes do regime militar. 0 campo da arquitetura, neste contexto, passava por uma série de transformações,

"de um lado a partir da exacerbação do viés produtivista da arquitetura moderna em favor da construção estatal e especulativa pesada; de outro, a partir da denuncia de sua face aparatosa e autoritária em meio à crise das promessas de desenvolvimento social e autonomia nacional"1.

Nesse sentido, tentar estabelecer uma ponte entre os dois estudos que nos propusemos desenvolver nesta dissertação, significaria empreender um novo trabalho, possivelmente de maior fôlego do que este que apresentamos aqui. No entanto, a partir da chave de leitura que nos propusemos a investigar, é possível traçar alguns questionamentos, e reconhecer tanto algumas aproximações quanto diferenças entre esses dois trabalhos de Flavio Motta, separados por dez anos, no sentido de recuperar algumas de nossas questões iniciais.

Os dois trabalhos têm em comum o fato de não se concentrarem num tema específico, ao contrário, seu objetivo é apresentar uma visão abrangente do país, passando por diferentes períodos e assuntos. Tendo, em ambos os casos, como destinatário o olhar 
estrangeiro, não focalizam a multiplicidade de obras arquitetônicas, realizações culturais ou circunstâncias históricas especificas, mas as organiza no interior de um esquema de formação, suficientemente sintético para fornecer a um público remoto um fio de entendimento do país e sua arquitetura sem o recurso ao panorama simplificado ou à caricatura convencional. Nesse sentido, organizam a narrativa à medida em que selecionam os acontecimentos e personagens que compõem essa interpretação. Quais seriam então as narrativas empreendidas por cada um desses trabalhos?

A estrutura narrativa de Introduzione al Brasile privilegia uma explicação das origens da arquitetura contemporânea, a qual insere numa ampla apresentação de um quadro histórico, privilegiando as características políticas e econômicas, e sua relação com a produção cultural no desenvolvimento do campo artístico. De um modo geral, pode-se dizer que é uma narrativa do passado, que recapitula os passos e tem na arquitetura contemporânea um ponto de chegada, e por essa razão, tem um sentido eminentemente historiográfico. Aí está uma de suas diferenças principais de nosso segundo objeto de estud, a exposição do Pavilhão. Ainda que este retome alguns acontecimentos históricos, e algumas experiências desenvolvidas num passado mais recente, ela é uma narrativa essencialmente propositiva, no sentido de que naquele discurso, que incorpora os avanços técnicos, a arte, a ciência, etc., reside uma visão de futuro: ali estão apresentadas propostas que representam possibilidades de desenvolvimento, não só de desenvolvimento econômico e tecnológico do país, mas também de um desenvolvimento humano e cultural, um projeto de ação.

Introduzione al Brasile apresenta uma possibilidade de entender o desenvolvimento da arquitetura moderna brasileira a partir de uma narrativa diferente daquela consagrada durante o começo dos anos 50, representando uma visão que busca constituir um quadro mais complexo do que aquele que é constantemente reiterado. Por sua vez, a exposição para - Pavilhão de Osaka emerge de um movimento já estabelecido, com premissas e pontos de partida claros, com um discurso afinado entre projeto e teoria, e entre o projeto arquitetônico e um projeto de desenvolvimento do país. Em comum, as duas leituras inserem o campo arquitetônico em contextos mais abrangentes, são narrativas que incorporam a arquitetura a considerações mais gerais acerca da cultura, da economia, das artes, etc. E ao mesmo tempo, em ambos os trabalhos, a arquitetura e os outros campos estabelecem entre si relações de rebatimento e reciprocidade, nem de autonomia nem de determinação, mas que impede que a arquitetura seja entendida de outro modo a não ser inserida nesse todo orgânico.

De um modo geral, pode-se dizer que os dois trabalhos são testemunhos de dois momentos de entrosamento de Flavio Motta com os arquitetos. Se em comum eles alertam para um dialogo mais estreito entre a produção e a critica, ao mesmo tempo assinalam 
momentos diversos desse processo, inicialmente marcado pela tomada de consciência e afirmação de um projeto alternativo, e posteriormente assinalando uma fusão de princípios e propósitos, idéias e formas.

No processo de estudo, também muitas outras questões foram surgindo e nos acompanharam durante o desenvolvimento do trabalho, algumas das quais, como de costume, acabaram sendo deixadas pra trás à medida em que nos concentramos em nossa matéria mais específica. Como enunciamos no início do primeiro capítulo, entre as muitas lacunas que podem ser identificadas no trabalho, a principal delas diz respeito à própria trajetória artística e intelectual de Flavio Motta, que continua a necessitar de trabalhos de maior fôlego, capazes de efetivamente trazerem à público toda a relevância de sua produção. Se nunca foi nosso objetivo tentar abarcar sua produção de um ponto de vista biográfico, foi necessário nos acercarmos do personagem de modo a nos aproximarmos de nossas questões iniciais.

Mas há muitos outros pontos de partida possíveis para trabalhos futuros que emergiram dessa aproximação a Flavio Motta. No mesmo sentido dos "estudos" que ele propõe, que não procuram respostas nem conclusões, mas ao contrário, buscam identificar em cada tema os desdobramentos que possam ser transformados em novas frentes de investigação, aqui também elencamos algumas questões que poderiam ser desmembradas em novas pesquisas.

Uma das questões que mereceria uma abordagem específica, e que foi apenas brevemente enunciada em nosso primeiro estudo, diz respeito às relações entre a crítica internacional, a crítica nacional e a arquitetura brasileira ao final dos anos 50. Conforme mostramos a partir do levantamento dos números especiais sobre o Brasil, se nos anos iniciais nesta década, a arquitetura brasileira havia ocupado um papel central nas pautas editoriais internacionais, o silêncio das revistas após Brasília nos deixa muitos questionamentos. É preciso compreender esse desinteresse pelo Brasil frente aos debates correntes no plano internacional naquele momento, e mais especificamente, frente à crise do movimento moderno que desponta na Europa em meados dos anos 50. No entanto, não deixa de ser intrigante o fato de a crítica internacional se desinteressar pela produção local quase ao mesmo tempo em que os mais renomados críticos internacionais se reúnem no país para o Congresso Internacional Extraordinário de Críticos de Arte em 1959. Não só pela oportunidade que tiveram de conhecer de perto a produção contemporânea, mas também pelo fato de assim como lá fora, o período ter sido marcado por novos alinhamentos teóricos, políticos e projetuais dos arquitetos brasileiros, o que produziria entre outras coisas trabalhos como os de Vilanova Artigas, Lina Bo Bardi, Paulo Mendes da Rocha, o grupo Arquitetura Nova, Sérgio Bernardes, curiosamente ausentes das resenhas e editoriais, da critica e da historiografia contemporâneas. 
Uma outra questão importante que se delineou neste trabalho, mas que não foi suficientemente investigada, é aquela que diz respeito às relações possíveis de serem traçadas entre o que é constantemente denominado um "brutalismo paulista" e as produções italiana, inglesa e japonesa do final da década de 50. Esta questão foi brevemente enunciada em nosso primeiro estudo, a partir da verificação de que a revista Zodiac, nos artigos de Flavio Motta e principalmente naquele de Bruno Alfieri, o movimento arquitetônico que vinha se desenvolvendo em São Paulo naquele período é pela primeira vez relacionado ao Brutalismo. As aproximações que Alfieri estabelece em seu artigo, entre Vilanova Artigas e o brutalismo, não se referem diretamente à produção dos Smithson, e sendo assim, permitem que pensemos que o contexto a que ele se reporta é outro. Nesse sentido, um estudo que se proponha a considerar a pertinência da designação "brutalista" para a arquitetura do grupo de São Paulo, poderia ter como questão de investigação essa "filiação" italiana da designação paulista, partindo da análise das obras e da produção contemporânea na Itália. Afinal, como bem notou Reyner Banham, em texto de $1961^{2}$, a designação genérica de brutalismo não diz nada, impedindo inclusive que a produção italiana sob essa rubrica pudesse ser identificada àquela que designa a sua contraparte inglesa.

Mais ainda, uma questão em aberto, que mereceria um olhar mais cuidadoso e que não foi mencionada com a devida importância neste trabalho, é a da proximidade e afinidade intelectual entre Flavio Motta e Lina Bo Bardi. Sabemos que Lina e Flavio compartilharam uma série de interesses e desenvolveram alguns trabalhos juntos, tanto no MASP, quanto na revista Habitat. Mais do que isso, podemos apreender nos depoimentos de Flavio Motta que Lina era um de seus principais interlocutores e que compartilhavam diversos interesses, especialmente aqueles relacionados às pesquisas de arte popular ${ }^{3}$. Esse diálogo por si só já justificaria um trabalho especifico. Inclusive para relativizarmos as aproximações aqui focalizadas entre ele e Paulo Mendes da Rocha, como se a arquitetura do segundo esgotasse o projeto critico do primeiro, ou suas interpretações esgotassem a obra do arquiteto.

Finalmente, cabe dizer que o convívio com Flavio Motta que este trabalho diretamente proporcionou, acabou por nos revelar uma série de lições e possibilidades, que permearam este trabalho em todo o seu processo de realização. Algumas delas, um pouco mais concretas, podem ser apreendidas através de seus textos, do exame de seu método de trabalho, da aproximação de sua produção como artista. Outras talvez sejam mais subjetivas, só capazes

Reyner Banham, " The history of immediate future", RIBA Journal, maio, 1961, pp.252-369.

3 Esse interesse específico compartilhado fica claro, por exemplo, se lembrarmos que Lina Bo Bardi publicou o texto "Arte e vida Urbana no Brasil", de Flavio Motta, em seu livro Tempos de grossura: o design no impasse, entre um conjunto de contribuições dos colaboradores que haviam participado de seus estudos. 
de ser compreendidas a medida em que adentramos mais sistematicamente em seu universo de ação e criação. Entre tantas lições possíveis, acreditamos que aquela que escolhemos como título deste trabalho talvez concretize, em sua amplitude, muito de seu modo de ver o mundo: ver não é só ver, no sentido de que qualquer coisa que se vê é capaz de nos remeter a muitos desdobramentos, dinâmicas e possibilidades. E ao mesmo tempo, aquele que vê o faz com os olhos do conhecimento e também da memória, uma memória que para Flavio, é sempre maior do que aquela individual - uma memória cultural, histórica e afetiva, que mobilizamos no simples ato de olhar. É através desse olhar, que ele nos mostra ser "um ver que vem de muitos", que "aquilo que parecia isolado, se encontra": encontra seu lugar no mundo, na história e num projeto coletivo criador. 



\section{bibliografia e fontes}

\section{livros e teses}

ALAMBERT, Francisco. As Bienais de São Paulo: da era do Museu à era dos curadores (19512001). São Paulo: Boitempo, 2004.

ALBUQUERQUE, Roberto Portugal. Uma escola de arquitetura - FAUUSP: edifícios e ensino. São Paulo: FAUUSP, 2004 (dissertação de mestrado).

ALMEIDA, Paulo Mendes de. De Anita ao Museu. São Paulo: Perspectiva, 1976.

ALVES, André Augusto de Almeida. Arquitetura e sociedade em São Paulo 1956-1968: projetos de Brasil moderno. São Paulo: FAUUSP, 2003 (Dissertação de mestrado).

AMARAL, Aracy. Arte para quê? A Preocupação social na arte brasileira 1930-1970. São Paulo: Nobel, 1984.

Projeto construtivo brasileiro na arte: 1950-1962. Rio de Janeiro: MAM, 1977.

ANELLI, Renato, GUERRA, Abilio e KON, Nelson. Rino Levi - Arquitetura e Cidade. São Paulo: Romano Guerra, 2003.

ANELLI, Renato. Interlocução com a arquitetura Italiana na constituição da arquitetura moderna em São Paulo. São Paulo: EESC-USP, 2001 (Tese de livre-docência).

Anistia na FAUUSP: A Reintegração dos Professores Cassados pelo Al5. São Paulo: FUPAM/FAU, 1998.

ARANTES, Otília Beatriz Fiori. Mário Pedrosa: itinerário Crítico. São Paulo: Scrita Editorial, 1991.

ARANTES, Pedro. Arquitetura Nova: Sérgio Ferro, Flávio Império e Rodrigo Lefèvre: de Artigas aos Mutirões. São Paulo: Editora 34, 2002.

ARGAN, Giulio Carlo. Arte e crítica de arte. Lisboa: Estampa, 1995.

Historia da arte como historia da cidade. São Paulo: Martins Fontes, 1992.

ARRUDA, Maria Arminda. Metrópole e Cultura: São Paulo no meio século XX. Bauru: EDUSC, 2001.

ARTIGAS, J. B. Vilanova. Caminhos da Arquitetura. São Paulo: Cosac \& Naify, 2004.

ASSOCIAÇÃO dos Docentes da USP. O controle ideológico na USP, 1964-1978. São Paulo: ADUSP, 2004.

Avery Index to architectural periodicals. New York: Columbia University Libraries.

AZEVEDO, Fernando de. A cultura brasileira. São Paulo: Melhoramentos, 1964.

BARDI, P. M. História do MASP. São Paulo: Empresa das Artes, 1992. p.38.

BASTOS, Maria Alice Junqueira. Arquitetura contemporânea brasileira após Brasília: discurso, prática e pensamento. São Paulo: FAUUSP, 2000 (Tese de Doutorado).

BAYEUX, Gloria Maria. Debate da arquitetura moderna brasileira nos anos 50. São Paulo: 
FAUUSP, 1991 (Tese de Doutorado).

BELLUZZO, Ana Maria de Moraes. Carmela Gross. São PAulo: Cosac Naify, 2000. Modernidade: Vanguardas artísticas na América Latina. São PAulo: Memorial /

Unesp, 1990.

BRAGA, Milton. O concurso de Brasília: os sete projetos premiados. São Paulo: FAUUSP, 1999 (Dissertação de mestrado).

BRUAND, Yves. "À margem do racionalismo: a corrente Orgânica e o Brutalismo paulista", in Arquitetura Contemporânea no Brasil. São Paulo: Editora Perspectiva, 1981.

BUZZAR, M. João Batista Vilanova Artigas: elementos para a compreensão de um caminho da arquitetura brasileira, 1938-1967. São Paulo: FAUUSP, 1996. (Dissertação de Mestrado).

CANDIDO, A. A revolução de 30 e a cultura. In A educação pela noite e outros ensaios. São Paulo: Ática, 1987

. Literatura e cultura de 1900 a 1945. In Literatura e Sociedade: estudos de teoria e história literária. 6a. ed. São Paulo: Companhia Editora Nacional, 1980.

CAPELLO, Maria Beatriz. Arquitetura em Revista: arquitetura moderna no Brasil e sua recepção nas revistas francesas, inglesas e italianas (1945-1960). São Paulo: FAUUSP, 2006 (Tese de doutorado).

COMAS, Carlos E. Dias. Precisões brasileiras: sobre um estado passado na arquitetura e urbanismo modernos a partir dos projetos e obras de Lucio Costa, Oscar Niemeyer, MMM Roberto, Affonso Reidy, Jorge Moreira \& Cia, 1936-1945. Paris: Universidade de Paris VIII, 2002. (Tese de doutorado).

COSTA, Eduardo. Brazil Builds e a construção de um moderno na arquitetura brasileira. Campinas: IFCH-UNICAMP, 2009 (Dissertação de mestrado).

COSTA, Lucio. Lucio Costa: registro de uma vivência. São Paulo: Empresa das Artes, 1995.

DEDECCA, Paula. Crítica paulista de arquitetura carioca. São Paulo: FAUUSP/CNPq, 2006 (Relatório final de iniciação científica).

DURAND, José Carlos. Arte, privilégio e distinção: artes plásticas, arquitetura e classe dirigente no Brasil, 1855/1985. São Paulo: Perspectiva, 1989.

FERRAZ, Geraldo. Warchavchik e a Introdução da Nova Arquitetura no Brasil: 1925-1940. São Paulo: Museu de Arte, 1965.

FIALHO, Valéria dos Santos. Arquitetura, texto e imagem: a retórica da representação nos concursos de arquitetura. São Paulo: FAUUSP, 2007 (Tese de Doutorado).

FICHER, Sylvia. Os arquitetos da Poli: ensino e profissão em São Paulo. São Paulo: EDUSP, 2005.

Histórico Brasileiro e a Faculdade de Arquitetura e Urbanismo da Universidade de São Paulo. São Paulo: FAUUSP, 1964.

GIMENEZ, Luis Espallargas. Arquitetura paulistana da década de 1960: técnica e forma. São Paulo: FAUUSP, 2004 (Tese de Doutorado). 
GOODWIN, Phillip. Brazil Builds, architecture new and old, 1652-1942. New York: The Museum of Modern Art, 1943.

GORELIK, Adrian. Das vanguardas a Brasília: cultura urbana e arquitetura na América Latina. Belo Horizonte: Editora UFMG, 2005.

HERBST, Helio. Promessas e conquistas: arquitetura e modernidade nas Bienais. São Paulo: FAU-USP, 2002.

JUNQUEIRA, Mônica. Brazilian presence in the historiography of Twentieth Century architecture. Paris: Docomomo, $n^{\circ}$ 34, março, 2006.

KAMITA, J.M. Vilanova Artigas. São Paulo: Cosac \& Naify, 2000.

KOURY, Ana Paula. Grupo arquitetura nova: Flávio Império, Rodrigo Lefrève e Sérgio Ferro. São Paulo: Romano Guerra /EDUSP, 2003.

LEON, Ethel. IAC Instituto de Arte Contemporânea, Escola de Desenho Industrial do MASP (1951-1953) - Primeiros estudos. São Paulo: FAUUSP, 2006. (Dissertação de mestrado).

LEONÍDIO, Otavio. Carradas de razões: Lucio Costa e a arquitetura moderna brasileira (1924-1951). São Paulo: Loyola / Ed. PUC Rio, 2007.

LIERNUR, Jorge Francisco. "Un nuevo mundo para el espiritu nuevo: los descubrimientos de América Latina por la cultura arquitectonica del siglo XX". In: Zodiac, n. 8, set. 1992fev. 1993, pp. 85-121.

LIRA, José Correia Tavares de. Fraturas da vanguarda em Gregori Warchavchik. São Paulo: FAUUSP, 2008. (Tese de livre-docência).

"Ruptura e construção: Gregori Warchavchik, 1917-1927", Novos Estudos n.78, jul. 2007.

. "Critica modernista e urbanismo: Geraldo Ferraz em São Paulo, da Semana a Brasilia". Anais do XI Encontro Nacional da ANPUR. Salvador: 23 a 27 de maio de 2005. LOURENÇO, Maria Cecília França. Operários da modernidade. São Paulo: Hucitec/EDUSP, 1995. . Maioridade do moderno em São Paulo, anos 30/40. São Paulo, FAUUSP, 1990. (Tese de doutorado).

MACADAR, Andrea. Uma trajetória brasileira na arquitetura das exposições universais dos anos 1939-1992. Porto Alegre, UFRGS, 2005 (Dissertação de mestrado).

MACHADO, Lourival Gomes. Retrato da Arte Moderna no Brasil. São Paulo: Departamento de Cultura, 1947.

MARTINS, Carlos. Arquitetura e Estado no Brasil - Elementos para uma investigação sobre a constituição do discurso moderno no Brasil: a obra de Lucio Costa 1924-52. São Paulo: FFLCH-USP, 1987. (Dissertação de Mestrado).

MINDLIN, Henrique. Modern Architecture in Brazil. Rio de Janeiro/Amsterdam: Colibri, 1956.

MIRANDA, Clara Luiza. Crítica nas revistas de arquitetura nos anos 50: a expressão plástica e a síntese das artes. São Carlos: EESC-USP, 1998. (Dissertação de Mestrado).

MORTEO, Enrico (org). Roberto Sambonet, designer, grafico, artista (1924-1995). Milão: Officina Libraria, 2008 
MOTTA, Renata Vieira da. O MASP em Exposição: mostras periódicas na Sete de Abril. São Paulo, FAUUSP, 2003 (Dissertação de mestrado).

NEVES, Juliana. Geraldo Ferraz e Patrícia Galvão: a experiência do Suplemento Literário do "Diário de São Paulo" nos anos 40. São Paulo: Annablume, 2005.

NOBRE, A.L. et alli. Lúcio Costa: um modo de ser moderno. São Paulo: CosacNaify, 2004.

NOBRE, Ana Luiza. Fios cortantes: projeto e produto, arquitetura e design no Rio de Janeiro (1950-1970). Rio de Janeiro: PPGHSC / PUC-Rio, 2008 (Tese de Doutorado).

PEDROSA, Mário. Dos murais de Portinari aos espaços de Brasília. São Paulo: Perspectiva, 1981. . Política das Artes. São Paulo: EDUSP, 1995.

PEIXOTO, Fernanda. Estrangeiros no Brasil: a missão francesa na Universidade de São Paulo. Campinas: UNICAMP, 1991 (Dissertação de mestrado).

PESAVENTO, Sandra. Exposições universais: espetáculos da moderninade no século XIX. São Paulo: Hucitec, 1997.

PONTES, Heloisa. Destinos mistos: os críticos do grupo Clima em São Paulo, 1940-1968. São Paulo: Companhia das Letras, 1998.

PONTUAL, Roberto. Dicionário das artes plásticas no Brasil. São Paulo: Civilização Brasileira, 1969.

REIS FILHO, Nestor Goulart. 100 anos de ensino de arquitetura e urbanismo em São Paulo. São Paulo: FAU-USP, 1996. . Quadro da Arquitetura no Brasil. São Paulo: Perspectiva, 1970.

SCHERER, Fabiano. Expondo os planos: as exposições universais do século XX e seus planos urbanísticos. Porto Alegre: UFRGS, 2002 (Dissertação de mestrado).

SEGAWA, Hugo. Arquiteturas no Brasil 1900-1990. São Paulo: EDUSP, 1997.

SODRÉ, João C. de Abreu. Viagens pelo Brasil a partir da FAU-USP, 1948-1962. São Paulo: FAUUSP, 2009 (Trabalho Programado).

SOUZA, Gilda de Mello. Exercícios de Leitura. São Paulo: Duas Cidades, 1980.

SOUZA, Ricardo Christiano. "Mário, crítico da atualidade arquitetônica". In: Revista do Patrimônio Histórico e Artístico Nacional - Mário de Andrade. Brasília, IPHAN, n³0, 2002, p.24-47.

SPADONI, Francisco. A transição do moderno: Arquitetura Brasileira nos anos 1970. São Paulo: FAUUSP, 2003 (Tese de Doutoramento).

SPERLING, David. "Arquitetura como discurso: o Pavilhão brasileiro em Osaka de Paulo Mendes da Rocha" in "Arquitextos 38", Portal Vitruvius, acessado em 03/08/09.

STUCHI, Fabiana Terenzi. Revista Habitat: um olhar moderno sobre os anos 50 em São Paulo. São Paulo: FAUUSP, 2007 (Dissertação de mestrado).

TAFURI, Manfredo. Storia dell'architettura italiana 1944-1985. Torino: Einaudi, 1982.

TAFURI, M. e DAL CO, F. Modern Architecture. Milão: Electa/Rizzoli, 1986.

TELLES, Sophia da Silva. Arquitetura Moderna no Brasil: o desenho da superfície. São Paulo: 
FFLCHUSP, 1988 (Dissertação de mestrado).

."A casa no Atlântico" In "Documento: Paulo Mendes da Rocha". AU, n60, 1995, pp. 70-72.

THOMAZ, D. E. Um Olhar sobre Vilanova Artigas e sua contribuição à arquitetura brasileira. São Paulo: FAUUSP, 1997 (Dissertação de Mestrado).

TINEM, Nelci. O Alvo do Olhar Estrangeiro: o Brasil na Historiografia da arquitetura moderna. João Pessoa: Manufatura, 2002.

WISNIK, Guilherme. "Arquitectura del territorio". In: Revista $2 G$ n॰ 45, Barcelona, Editorial Gustavo Gilli, 2008.

Formalismo e Tradição: a arquitetura moderna brasileira e sua recepção crítica. São Paulo: FFLCHUSP, 2003 (Dissertação de Mestrado).

XAVIER, A. F. Depoimentos de uma Geração. São Paulo: PINI, 1986.

ZANINI, Walter. História geral da arte no Brasil. 20 volume. São Paulo: Instituto Walter Moreira Salles, 1983.

ZEIN, Ruth Verde. A arquitetura da escola paulista brutalista: 1953-1973. Porto Alegre: UFRGS, 2007 (Tese de Doutorado).

\section{periódicos}

Acrópole, n.361, maio, 1969.

ANDRADE, Mario de. "Esta paulista família", O Estado de São Paulo, 02/07/1939

Architectural Record, n.1, v.93, janeiro, 1943.

Arte em Revista, n.4, 1980.

Arquitectura Mexico, n.64, v.14, dezembro, 1958.

BARR, Margaret Scolari. "Our Campaigns: Alfred H. Barr, Jr., and the Museum of Modern Art: A Biographical Chronicle of the Years 1930-1944." The New Criterion, 1987, pp. 23-74.

Caramelo, n.6, 1993.

FERRAZ, Geraldo. "Quem é o pioneiro da arquitetura moderna brasileira? Falta o depoimento de Lucio Costa". Diário de São Paulo, 01/02/ 1948.

Habitat, n.1, v. 01, 1950.

Habitat, n.2, v. 01, 1951.

Habitat, n.7, v. 03, 1952.

L'Architecture D'Aujourd'Hui, n.13-14, v. 18, setembro, 1947.

L'Architecture d'aujourd'hui, v.23, agosto, 1952.

MACHADO, Lourival Gomes. "Três notas sobre Itu", in Suplemento Literário, O Estado de São Paulo, 18/02/1962.

Módulo, n.42, mar/abr/maio, 1976.

New Pencil Points, janeiro, 1943. 
Proa, n.11, abril, 1948.

Sinopses, "Edição especial: memória". São Paulo: FAUUSP, 2993.

The Architectural Forum, n.5, v. 87, novembro, 1947.

The Architectural Review, n.567, v. 95, março, 1944.

The Architectural Review, n.646, v.108, dezembro, 1950.

The Architectural Review, n.679, v.114, julho, 1953.

The Architectural Review, n.694, v.116, outubro, 1954.

The Studio, n.607, v.126, outubro, 1943.

Zodiac, n.1, novembro, 1957.

Zodiac, n.2, maio, 1958.

Zodiac, n.3, novembro, 1958.

Zodiac, n.4, maio, 1959.

Zodiac, n.5, novembro, 1959.

Zodiac, n.6, maio, 1960.

\section{de Flavio Motta}

\section{trabalhos acadêmicos e textos de aulas}

Contribuição ao Estudo do Art-Noveau no Brasil. Tese para concurso de cátedra. São Paulo: FAUUSP, 1957.

Exposição Victor Brecheret. São Paulo, FAUUSP, 1962.

Apontamentos de história da arte: o sorriso da Gioconda. São Paulo: FAUUSP, 1963.

Apontamentos de história da arte: milagre da fonte. São Paulo: FAUUSP, 1963.

Arte cinética e pop art. São Paulo: FAUUSP, 1969.

"Desenho e Emancipação", in Desenho industrial e comunicação visual. São Paulo: FAUUSP, 1970.

Subsídios para um relatório sobre ensino de arquitetura (UIA-UNESCO). São Paulo, FAUUSP, s.d.

Textos informes. São Paulo, FAUUSP, 1973.

\section{livros e capítulos}

"400 anos de pré-história das artes". São Paulo, Gráfica Municipal, 1954. [Separata do volume: IV Centenário da Fundação da Cidade de São Paulo]

"Visconti e o início do século XX", in PONTUAL, Roberto. Dicionário das artes plásticas no

Brasil. Rio de Janeiro, Civilização Brasileira, 1969.

"Trabalho de um pintor: Portinari", in Revista de História. São Paulo, 1972.

Tudo novo. São Paulo: Fernando Millan / Gráfica Martinez, 1974.

Love story. São Paulo: FAUUSP, 1974.

"Art-nouveau, modernismo, ecletismo e industrialismo", [pp.453-484] in ZANINI, Walter (org.).

História geral da arte no Brasil. São Paulo: Instituto Moreira Salles, 1983.

Roberto Burle Marx e a nova visão da paisagem. São Paulo, Nobel, 1938. 
artigos em periódicos

"Verde em São Paulo", Habitat, n. 6, p.72-3, 1952.

"Saul Steinberg no Brasil". Habitat, São Paulo, v.9, p.17, 1952.

"São Paulo e o Art-Noveau". Habitat, São Paulo, v.10, p. 3-18, 1953.

"A primeira turma da escola de propaganda". Habitat n.11, p.81, 1953.

"Intercâmbio com Pellizzri". Habitat, n. 11, p.61, 1953.

"A época do SPAM". Habitat, São Paulo, v.11, p.49-60, jun. 1953.

"Prédio em Campinas" Habitat, n. 12, p.9, 1953.

"Prédio Nações Unidas" Habitat, n. 12, p.10, 1953.

"O arquiteto Milton Roberto" Habitat, n. 12, p.12, 1953.

"Um lift para Paris". Habitat, n. 12, p.1, 1953.

"Floreal", Habitat, n. 12, p.58, 1953

"O antigo e o novo Itamarati". Habitat, n. 13, p.31, 1953.

"Gravuras: David Perlow". Habitat, n. 13, p.67, 1953.

"Afrescos: Penacchi". Habitat, n. 13, p.68, 1953.

"Pintor Solitário: Mercier". Habitat, n. 13, p.70, 1953.

"Gravuras: Giselda". Habitat, n. 13, p.72, 1953.

"Inéditos de Brecheret". Habitat, n. 13, p.74, 1953.

"Escultura: Karl Hansen". Habitat, n. 13, p.75, 1953.

"Escultura nova" Habitat, n. 13, p.76, 1953.

"Zélia Salgado". Habitat, n. 13, p.77, 1953.

"O museu num álbum". Habitat, n. 13, p.78, 1953.

"Introduzione al Brasile". Zodiac, n.6, p.61-67, 1960.

"As artes plásticas em São Paulo", São Paulo: Terra e Povo. Porto Alegre: Globo, 1966, pp.209-227.

"Paulo Mendes da Rocha". Acrópole, São Paulo, n. 343, p.17-18, set. 1967.

“Arquitetura brasileira para a Expo'70”. Acrópole, São Paulo, n. 372, p.25-26, abr. 1970.

"A família artística paulista". Revista do Instituto de Estudos Brasileiros, São Paulo, n.10, 1971, pp.137-154.

"Superfícies Habitáveis: memorial 3". Módulo, n. 42, mar, 1976, p.48.

"Sérgio Ferro". Projeto, São Paulo, v.32, ago, 1981. p.21.

“João Vilanova Artigas e a escola de São Paulo". Módulo especial Vilanova Artigas, 1985, p.23.

\section{anais de congressos}

Anais do Congresso Internacional Extraordinário de Críticos de Arte. Rio de Janeiro, Brasília e São Paulo, setembro de 1959.

Anais do Congresso Internacional de Críticos de Arte. Rimini e Verucchio, 1965.

"Convênio internacional de artistas, críticos e estudiosos de arte", Rimini e Verucchio, Itália, 1965. Separata da Revista de História, n.67, São Paulo, 1967. 


\section{acervos pesquisados}

Acervo pessoal de Flavio Motta

Acervo pessoal de Paulo Mendes da Rocha

Acervo pessoal de Domingos Theodoro Azevedo

Arquivo do Departamento de História da FAUUSP

Arquivo do Estado de São Paulo

Avery Library, Columbia University

Biblioteca da FAUUSP

Museu de Arte de São Paulo

\section{depoimentos}

Flavio Motta - entre dezembro de 2007 e novembro de 2009.

Paulo Mendes da Rocha - 07/04/2008, 02/04/2009, 14/11/2009.

entrevista com Julio Roberto Katinsky, 21/08/2009. 


\section{lista de imagens}

\section{Flavio Motta, entre a arte e o ensino}

$\begin{array}{ll}\text { p.43 } & \text { 1. P.M. Bardi, História do MASP, op.cit., p.67. Foto de Peter Scheier } \\ \text { p.44 } & \text { 1. Idem, ibidem, p.59. } \\ \text { p.51 } & \text { 1. Idem, ibidem, p.69. } \\ & \text { 2. Idem, ibidem, p.77. } \\ \text { p.58 } & \text { 1 e 2. João Xavier, acervo pessoal. } \\ \text { p.63-64 } & \text { 1 a 5. João Xavier, acervo pessoal. } \\ \text { p.66 } & \text { 1. BRAGA, Milton. O concurso de Brasília: os sete projetos premiados. São Paulo, } \\ & \text { FAUUSP, Dissertação de mestrado, 1999, p.89. } \\ \text { p.73 } & \text { 1. Flavio Motta, Contribuição ao estudo do art-noveau. São Paulo, FAUUSP, Tese de } \\ \text { p.75 } & \text { cátedra, 1957. } \\ \text { p.77-78 } & \text { 1 a 3. Revista Módulo, n.42. março/abril, 1976, p.48. } \\ \text { p.79 } & 1 \text { e 2. convite de exposição. Acervo da autora } \\ \text { p.80 } & 1 \text { a 4. Flavio Motta, Tudo novo. São Paulo, FAUUSP, 1974. } \\ \text { p.81-82 } & 1 . \text { Vilanova Artigas, A função social do arquiteto. São Paulo: Nobel, 1989, p.73. }\end{array}$

\section{Do cânone a Zodiac}

\begin{tabular}{|c|c|}
\hline \multirow[t]{6}{*}{ p.82-83 } & 1. Revista Zodiac, n.1, 1957 \\
\hline & 2. Revista Zodiac, n.2, 1958 \\
\hline & 3. Revista Zodiac, n.3, 1958 \\
\hline & 4. Revista Zodiac, n.4, 1959 \\
\hline & 5. Revista Zodiac, n.5, 1959 \\
\hline & 6. Revista Zodiac, n.6, 1960 \\
\hline \multirow[t]{8}{*}{ p.90-91 } & 1. New Pencil Points, janeiro, 1943. \\
\hline & 2. Architectural Record, n.1, v.93, janeiro, 1943. \\
\hline & 3. The Studio, n.607, v.126, outubro, 1943. \\
\hline & 4. The Architectural Review, n.567, v. 95, março, 1944. \\
\hline & 5. L'Architecture D'Aujourd'Hui, n.13-14, v. 18, setembro, 1947. \\
\hline & 6. The Architectural Forum, n.5, v. 87, novembro, 1947. \\
\hline & 7. Proa, n.11, abril, 1948. \\
\hline & 8. The Architectural Review, n.646, v.108, dezembro, 1950. \\
\hline
\end{tabular}


9. L' Architecture d'aujourd'hui, n.xx, v.23, agosto, 1952.

10. The Architectural Review, n.679, v.114, julho, 1953.

11. The Architectural Review, n.694, v.116, outubro, 1954.

12. Arquitectura Mexico, n.64, v.14, dezembro, 1958.

p.110-113 1. Revista Zodiac, n.6, maio 1960. capa.

2. Idem, ibidem, índice.

3 a 6. Idem, ibidem, pp. 60-67.

\section{O pavilhão de Osaka, feito até de arquitetura}

$\begin{array}{ll}\text { p.125 } & \text { 1. Revista JA, n.4-151, v.44, abril, 1969, p.13-14. } \\ \text { p.127 } & \text { 1. idem, ibidem, p.41. } \\ & \text { 2. idem, ibidem, p.41. } \\ & \text { 3. idem, ibidem, p.34. } \\ \text { p.128 } & \text { 1 e 2. Acervo de Paulo Mendes da Rocha. } \\ \text { p.130 } & \text { 1. cartão-postal. Acervo de Domingos Theodoro Azevedo. } \\ \text { p.131 } & \text { 1. mapa da Expo70. Acervo de Domingos Theodoro Azevedo. } \\ \text { p.136 } & \text { Revista Acrópole, n.361, 1969, p. } 18 . \\ \text { p.138 } & \text { Revista Acrópole, n.361, 1969, p. } 21 . \\ \text { p.140 } & \text { Revista Acrópole, n.361, 1969, p. } 23 . \\ \text { p.141 } & \text { Revista Acrópole, n.361, 1969, p. } 24 . \\ \text { p.146-147 } & \text { 1 a 8. acervo de Paulo Mendes da Rocha. } \\ \text { p.149 } & \text { revista Acrópole, n.361, 1969, p. } 15 . \\ \text { p.149 } & \text { revista Acrópole, n.361, 1969, p. } 16 . \\ \text { p.151 } & \text { acervo de Paulo Mendes da Rocha } \\ \text { p.153 } & \text { acervo de Paulo Mendes da Rocha } \\ \text { p.154 } & \text { acervo de Paulo Mendes da Rocha } \\ \text { p.158-159 } & \text { 1 a 5. acervo de Paulo Mendes da Rocha } \\ \text { p.164 } & \text { 1. acervo de Paulo Mendes da Rocha } \\ \text { p.172-173 } & \text { 2. cartão-postal, acervo de Domingos Theodoro Azevedo } \\ \text { p.178 } & \text { 1 a 10. acervo de Paulo Mendes da Rocha } \\ \text { p.182-183 } & \text { 1 e 2. cartões-postais, acervo de Domingos Theodoro Azevedo } \\ & 1 \text { a 4. catálogo, acervo de Domingos Theodoro Azevedo } \\ \end{array}$

\section{Anexos}




\section{anexo 1}

\section{tradução do artigo Introduzione al Brasile,}

Flavio Motta, Revista Zodiac n.6, 1960.

\section{Introdução ao Brasil}

Para falar de arquitetura brasileira sem cair nos costumeiros juízos formalistas, e tentando apontar as novas possibilidades expressivas, é indispensável situar antes algumas rápidas considerações sobre a formação histórica do país.

A valorização do potencial humano e territorial, o significativo aumento da população, o intenso desenvolvimento industrial e urbano (a população urbana de 1940 a 1950 aumentou 49\%), são aspectos que requerem a formação de arquitetos com uma ampla visão dos problemas sociais. A exigência de planejamento tornou-se fator decisivo para a obtenção de uma forma plena da nação. São problemas caracteristicamente políticos.

Basta recordarmos o que dizia Euclides da Cunha em seu livro "À margem da História"1, ao início do século: "Somos o único caso histórico de uma nação feita a partir de uma teoria política. Passamos de um só golpe da homogeneidade da colônia ao regime constitucional, dos beneplácitos reais às leis. E entrando de improviso na órbita dos nossos destinos, o fizemos com o único equilíbrio possível naquela época: o equilíbrio dinâmico entre aspirações populares e tradições dinásticas". É necessário compreender que foram estas tradições dinásticas os principais determinantes da unidade nacional. As aspirações populares, inicialmente identificadas com a causa da independência e do Imperador, tiveram que, por outro lado, se desenvolver através de formas liberais até a República.

A gradual autonomia das forças populares acompanhou a marcha do desenvolvimento econômico. É curioso observar que o Brasil, no tempo do governo do Visconde de Rio Branco (1871-1875), lançava as bases da educação pública, profissional e superior; criava algumas escolas politécnicas; construía ferrovias; realizava as primeiras pesquisas estatísticas; quadruplicava a imigração que chegava a 
30.500 trabalhadores ao ano e, em 1874, com a instalação do telégrafo, recebia o primeiro telegrama da Europa. Um pouco mais tarde Ruy Barbosa, em 1882, no seu "Parecer sobre o ensino primário" deu as novas condições para a educação no Brasil, frente à indústria nascente. Afirmava Barbosa: "criar uma consciência industrial: eis a fórmula racional do único estímulo eficaz à industrialização do país". E acrescentava: "Se este ensinamento atinge tais resultados, isto é principalmente devido ao culto racional, metódico, ramificado em numerosas instituições, do desenho industrial."2 Propunha também a criação de um "Instituto superior de artes aplicadas que não tenha nada a ver com as Academias".

Foi nesse clima de interesse na força produtiva e cultural que a república se instalou pacificamente no Brasil. Poder-seia afirmar que o Império foi a grande fase política e a república a fase econômica da unidade nacional. O significado substancial dessa nova etapa corresponde aquilo que enunciava Euclides da Cunha: "A nossa evolução, por ser estritamente política, era problemática. Pelo menos ilusória. Estava numa minoria educada à européia. $\mathrm{O}$ resto permanecia nas mesmas condições nas quais a metrópole o havia deixado: obscuro e incerto amalgama proteiforme de brancos, negros e indígenas, uns e outros praticamente e moralmente prejudicados pela escravidão crescente por causa do tráfico que não queria extinguir-se".
As estradas deste desenvolvimento econômico se tornaram tortuosas. Entre outras coisas, a monocultura do café foi um grande obstáculo a industrialização, mesmo quando ela parecia irrefreável. Se não fosse pela identificação entre as exigências econômicas gerais e a maior parte da população, desejosa de consolidar uma atmosfera criativa, seria ainda hoje problemático este desenvolvimento. Não se trata aqui portanto, no caso do Brasil, de traçar um esboço do perfil nacional, como reflexo de uma demonstração de força, prestígio e poder econômico, mas sobretudo, como uma tentativa de salvaguardar um "modus vivendi", um tipo de civilização, uma organização isenta de preconceitos raciais; uma civilização atada aos problemas humanísticos da latinidade; uma civilização que tem tanto da européia, como da indígena, asiática, africana, norte-americana e católica. É nesta ebulição, nesta fermentação de impulsos tão contraditórios, que se aguça a sensibilidade política do homem brasileiro, desejoso de encontrar uma formula superior de integração cultural. O fenômeno da industrialização, as conquistas da técnica e da ciência, são aqui destinadas a diluirse nos interesses por esse tipo de unidade civilizadora. Ontem, na simbologia de um Império; hoje, na realidade contingente de um povo, para chegar a uma fisionomia própria no quadro da civilização.

O traço dominante da marcha para uma maior caracterização cultural do Brasil 
já se define na época colonial, quando as manifestações artísticas e em particular a arquitetura - por quanto sob influência portuguesa -já têm uma linguagem própria, seja no emprego de novas técnicas construtivas, na organização do espaço ou nas peculiares formas barrocas de sua ornamentação. As características regionais permitem falar de uma arquitetura colonial baiana, pernambucana, mineira ou paulista - condicionada pelos grandes ciclos "bandeirantes", por exemplo, que nos séculos XVII e XVIII organizaram expedições de brancos, negros e índios, destinadas a procurar riquezas no interior do continente, representam o primeiro esforço de auto-colonização e de "paz étnica" de um organismo social que gerou formas arquitetônicas particulares. O despertar deste espírito nacional adquiriu um novo impulso com a vinda de D. João VI, expulso pela invasão napoleônica em Portugal. "O despertar de uma voz do seio de um novo Império" - como dizia o manifesto de 1808, criou, além de novas condições de mercado com a abertura dos portos, novas possibilidades para a vida artística e literária: era o florescimento da imprensa brasileira e a chegada da "Missão Francesa" (1816) com a conseqüente fundação da Academia de Belas Artes, onde pontificou o arquiteto neo-clássico Grandjean de Montegny. O neoclassicismo se afirmou, através da Academia, colocando urgentemente o problema do ensino artístico. Impôs “cânones", que mesmo não correspondendo às exigências latentes das formas espontâneas de expressão brasileira, provocaram um progresso qualitativo. Centralizando a vida cultural do país, a cidade do Rio de Janeiro, e com ela a Academia com todos os seus rigores formais, serviam aos ideais de unidade do Império.

As crescentes trocas com outros países, o incremento da imigração, as premissas do movimento industrial, as novas forças produtivas da república - todos esses fatores criavam a necessidade de uma nova revisão fundamental. A academia, por exemplo, se sustentou, em grande parte, graças ao paternalismo de D. Pedro II; para, em seguida, vacilar com o novo regime. Em um artigo intitulado "É preciso animar a arte nacional”, Ernesto da Cunha Araújo Viana observava, em 1900: "O Imperador encorajou a arte, deu prestígio aos artistas, e a república os conduziu a decadência”. Acrescentava em seguida, num verdadeiro balanço da época: "O século morre sem a herança de uma arquitetura exclusiva. Será considerado pelos arquitetos como uma época de transição, dedicada ao estudo da obra de todos os tempos e todos os países, caracterizado pela imitação eclética ou cosmopolita, adaptada as condições climáticas das várias regiões, segundo o progresso da ciência e da indústria." Essa dupla visão - de um lado preocupada com o desenvolvimento da arte nacional, e de outro reagindo ao ecletismo dos "neo"- se dizia apresentar como novo 
fator positivo ao início da República.

Este esforço de revisão correspondia ao esquema federalista da República, animador das forças econômicas regionais. A autonomia crescente descobria as peculiaridades das províncias. São Paulo, entre elas, graças ao café, à imigração e a industrialização, recebeu um impulso particular. Aqui os liberais propunham soluções fisiocráticas para a industrialização. Ampliava-se o ensinamento técnico e profissional, onde a arquitetura era apêndice da engenharia. No Rio de Janeiro, ao contrário, o ensinamento da arquitetura era integrado às “belas artes”. Mas, ainda em São Paulo, o ensinamento das outras artes plásticas girou na órbita do "Liceu de artes e ofícios", onde proliferavam as primeiras manifestações do art-noveau brasileiro. No Rio, a academia retardava este processo. Será em São Paulo, um arquiteto como Victor Dubugras, evoluindo do "neo-gótico" ao "art-noveau", revalorizava os valores de origem, se tornando o porta-bandeira do "neocolonial brasileiro", que nasce na época da primeira guerra mundial, durante um período no qual a industrialização insuficiente não correspondia mais à exigência do desenvolvimento total da nação. No caso específico, Victor Dubugras terminará seus dias construindo segundo o estilo "neocolonial brasileiro" para famílias abastadas do Rio. Se configura desta forma, nos primeiros anos da república, o caráter "doméstico" do movimento paulista, com o indispensável "artes e ofícios" seguindo a moda, a bem dizer, dos bons liberais britânicos. Era também o tempo no qual os empreendedores paulistas faziam a previsão orçamentária de suas empresas em liras esterlinas.

Em 1922, os intelectuais paulistas menos sujeitos ao paternalismo rigoroso e tenaz dos plantadores de café, davam vida a um movimento semi-anárquico que ecoava por todo o Brasil, como exigência de liberalização e convivência mutua. Surge a figura do escritor, poeta e crítico Mario de Andrade e inúmeros outros intelectuais preocupados em realizar uma cultura brasileira, e ao mesmo tempo inquietos investigadores das mais avançadas realizações da arte européia: amigos de Brancusi, Cendrars, Léger e Marinetti; colecionadores de obras de Lipchitz, Picasso. Dufy, Delaunay, De Chirico, Matisse e Modigliani. Todavia, no terreno da arquitetura, as manifestações são mais esporádicas. É só em 1925 que Gregori Warchavchik publica um "Manifesto da arquitetura funcional” e Rino Levi lança um apelo por uma política de urbanização. Em 1927, Flavio de Carvalho escandaliza o público com um projeto moderno para o palácio do governo e em 1928 Warchavchik constrói a primeira residência moderna em São Paulo. Porém essas novas propostas são apresentadas paralelamente ao Movimento Antropofágico. Oswald de Andrade e outros intelectuais do movimento de 22 buscam entre a lenda dos indígenas antropófagos uma visão grandiosa e sincretizante do 
país. Por isso o Brasil era como a gigantesca figura do "Abaporu antropófago" (pintado por Tarsila do Amaral) que tudo devora. Como os indígenas se alimentavam dos inimigos para apossar-se da sua força, assim também o Brasil possui esta divina capacidade digestiva. Neste mesmo ano o escritor Mario de Andrade cria a figura pantagruélica de "Macunaíma - o herói sem caráter", simbolizando a coexistência da mutabilidade indígena com a civilização. A partir deste momento o movimento de 22 passa da esfera local àquela nacional. Era, no âmbito da cultura, quase uma antecipação da Revolução de 30, que sacudiu as fundações da republica, em uma agitação provocada por aquilo que se chamou "o general café".

O Brasil mergulhou em direção aquela ditadura "iluminada" que durou até a segunda guerra mundial. Mas conquistou uma legislação social avançada e uma indústria de base. Reforçou o poder central. Sufocaram-se as agitações regionais. O Rio de Janeiro retoma o timão das principais manifestações culturais atraindo as novas personalidades formadas na região nordeste onde o Manifesto Regionalista de 1926 proclamou novos caminhos para a arte e a ciência. Foi lá no rio de janeiro que conquistaram fama os pintores Portinari e Lasar Segall; a música de Villa Lobos; os poemas de Manuel Bandeira e Carlos Drummond de Andrade; a obra literária de Jorge Amado, José Lins do Rego e Graciliano Ramos; a visão sociológica de Gilberto
Freire; a etnografia de Arthur Ramos; a poética de Mario de Andrade. O movimento da arquitetura moderna que tinha apenas se esboçado vinha rapidamente delineandose. Em São Paulo já havia se manifestado; e no Rio, as crescentes realizações antiacadêmicas, terminaram por transformar o gosto pelo "neo-colonial" no interesse por uma arquitetura brasileira, "brasileira" não tanto em seus aspectos formais $\mathrm{e}$ ornamentais, quanto em seus valores de estrutura, função e outros atributos que pareciam inerentes a tradição arquitetônica. É isto, em grande parte, mérito de Lucio Costa. Sua obra realizou-se na contínua meditação e confronto com os outros vertentes da arquitetura contemporânea.

Sob influência de intelectuais como o poeta e musicólogo Mario de Andrade, o escritor Rodrigo de Mello Franco, Carlos Drummond de Andrade e outros, vinham oficialmente acolhidos os novos valores, e isto trouxe o desenvolvimento das mais expressivas e concretas manifestações da arquitetura brasileira contemporânea.

A presença de Le Corbusier, no Rio de Janeiro, foi um fator determinante a esta orientação. Cumpria a missão de um perfeito propagandista, um mestre que entusiasmava a juventude com sua exuberante força criativa e doutrinária. Todas as características dessa nova arquitetura, num progressivo e ininterrupto desenvolvimento, vinham ao encontro da realidade social e econômica. Viviam, contudo, da vitalidade emocional de 
uma rebelião, através da qual fluía a fantasia generosa de Oscar Niemeyer, produzindo sobressaltos na trama diabólica do calculista de concreto armado Joaquim Cardoso. Era o estímulo, como se a visão poética fosse o momento primeiro das coisas. Era, enfim, o estímulo da "Corte", suscetível às rápidas deformações à causa do provincianismo. Sim, o provincianismo se tornava o maior parasita; o provincianismo que o poeta Fernando Pessoa classificou como mania do grande, mania do moderno e incapacidade para a ironia. O poético se particularizava, mas não se individualizava. Multiplicava os elementos, mas não criava formas. Ainda hoje, Oscar Niemeyer, em uma verdadeira autocrítica que publicamos nestas páginas de Zodiac 6, denuncia esse estado de coisas. O seu grande objetivo: conservar as conquistas qualitativas da arquitetura contemporânea brasileira. Mas, a bem dizer, isto é hoje uma espécie de palavra de ordem no Brasil, onde agora a profissão do arquiteto adquire maior significado, seja pela existência do Instituto de Arquitetos, seja com a fundação, depois da última guerra, das escolas de arquitetura, onde o espírito crítico e de equipe adquiriu um novo significado.

Os determinantes do Movimento Moderno, dia após dia subjugado a "corrida imobiliária” e aos fenômenos paralelos, são objeto de contínuas discussões e de reivindicações de âmbito coletivo. Não deveria passar despercebido que se agitou o processo de independência nacional, mesclando-se a iniciativa privada a estatal, onde a primeira absorve os lucros e a segunda estimula as empresas, em um processo nem sempre reversível em benefício da coletividade. Em um certo senso, é o estado mesmo que forma a burguesia; burguesia esta, que deve enfrentar responsavelmente os grandes problemas do planejamento nacional. Para que possa realizar este programa não deve, entre outras coisas, esquecer-se que em São Paulo (3.231.462 habitantes) e no Rio de Janeiro (2.984.988 habitantes) a ausência de um plano regulador é a causa do mal-estar social. O caráter de fechado individualismo que ameaça denegrir o papel civilizatório da burguesia brasileira, requer, sobretudo, uma revisão histórica. Quando Euclides da Cunha dizia que no Império o único equilíbrio possível era "o equilíbrio dinâmico entre as aspirações populares e as tradições dinásticas", estava atribuindo às tradições dinásticas um caráter simbólico no âmbito da unidade nacional. Hoje esta missão é, na maior parte, da burguesia. Contudo, se compete a burguesia grande parte desta atribuição de planificação econômica, é em última análise, tarefa dos intelectuais defender a fisionomia política do país, as suas exigências culturais, necessárias à atividade criativa, expressão do "equilíbrio dinâmico" que emana das aspirações populares.

Se coloca assim, na fase atual da vida brasileira, a figura do arquiteto como intelectual e como principal artífice da nação. Cabe ao arquiteto contribuir do melhor 
modo na orientação dessa burguesia em sua fase de planejamento. Ao enfrentar estes problemas, deve estar atento à continuidade e à harmonia da produção, naquilo que concerne à organização do espaço, ao adequado emprego dos materiais, e a individualidade expressiva de sua obra como fato de cultura. Por outro lado, a formação universitária do arquiteto representa um enriquecimento do quadros, cujo significado foi expresso no último encontro realizado em São Paulo entre arquitetos, professores e estudantes de arquitetura de todos os estados do Brasil. Aqui foram definidas as atribuições e reivindicações do arquiteto, seja buscando um modo de frear à especulação imobiliária, seja buscando uma maior diferenciação do engenheiro civil, com o qual ainda hoje é confundido em uma lei antiquada e absurda. Ainda hoje, no Brasil, foram profissionais sem formação humanística, os co-autores inconscientes das realizações do mais grosseiro "privativismo". Acrescentase que a contribuição dos novos arquitetos, formados em escolas de criação recente, já se faz sentir.

Não obstante não exista uma longa tradição no ensino da arquitetura, é hoje possível no Brasil instituir tal ensinamento com relativa organicidade, uma vez que as maiores preocupações são voltadas ao caráter formativo; aos imperativos metodológicos; ao sentido decrescente dos fatores instrumentais e informativos; ao estímulo das manifestações espontâneas em escala crescente de integração na consciência civilizadora. Por outro lado, se deve notar, ultimamente, entre os arquitetos em evidência, a procura de uma maior eficácia nas conquistas técnicas, como vemos na obra de Sergio Bernardes ${ }^{3}$, para a Feira da Indústria que está em construção no Rio de Janeiro, nas numerosas obras de Niemeyer em Brasília, no refinamento dos detalhes construtivos de Afonso Eduardo Reidy e Jorge Moreira, ou ainda na sintaxe disciplinada de Rino Levi.

Entretanto, se quisermos citar ainda um exemplo entre os nomes menos conhecidos da crítica estrangeira, encontramos aquele do arquiteto Vilanova Artigas que realiza em São Paulo uma intensa atividade doutrinária, seguindo o exemplo de Lucio Costa no que diz respeito às exigências de uma posição teórica. Seja a sua obra que o conteúdo irreverente da sua especulação, assume, algumas vezes, um caráter até brutal. Influenciado inicialmente por Frank Lloyd Wright, Artigas não deixou de observar o fenômeno "liberty" no Brasil, e teve a rápida intuição de que as premissas moderna deste movimento foram prejudicadas pelas condições sociais e econômicas do país. As suas realizações revelaram o esforço de alcançar novas formas através de processos construtivos independentes da instabilidade da indústria da construção nascente. As suas casas de moradia, projetadas para intelectuais $\mathrm{e}$ profissionais liberais, são caracterizadas pela economia de recursos da construção, onde, às vezes, $\mathrm{o}$ arquiteto se mistura intimamente 
à atividade do mestre-de-obra e do operário. Hoje as suas realizações vão amadurecendo em direção a um aparente "brutalismo". Deve-se notar que muitas vezes no "brutalismo", a agressividade é denunciada mas não se expressa como maturidade afetiva e emocional, ou seja, como fator de integração social. Aquilo que esse arquiteto brasileiro procura é a expressão da energia que penetra na matéria com o vigor e a obstinação de quem não impõe limite ao espaço, mas o escava procurando o vazio para o homem. Pensamos que isto e é um exemplo que ilustra uma das tendências mais significativas da arquitetura brasileira nesta fase onde a figura do arquiteto se assemelha ao lendário "bandeirante", que abatia a floresta e construía sólidas habitações.

Portanto, ainda que as tendências da arquitetura se multipliquem, parece mais apropriado definir a perspectiva para o urbanismo como um novo e absorvente capítulo na história da cultura brasileira. E nesse sentido se apresenta o projeto de urbanização de Cabo Frio, realizado pelos Irmãos Roberto e naturalmente o já conhecido exemplo de Brasília.

Brasília - a obra de Lucio Costa e Oscar Niemeyer - fora de qualquer consideração quanto a sua "funcionalidade", ou não, no futuro, como nova capital do Brasil, como visão introspectiva do país, exemplo de planificação, desejo de unidade nacional, é um dos mais estimulantes fatos culturais e políticos destes últimos anos da República e que amplia os horizontes da nova geração de arquitetos. Brasília demonstrará quanto seja necessário, na formação do arquiteto, uma consciência política, no sentido mais puro da palavra: isto é, político e civilizador, que acolha os anseios de uma cultura configurada pelas necessidades íntimas de um povo.

notas

1 À Margem da História. Porto, Livr. Chardron, de Lello \& Irmão, 1909 [ $1^{\text {a }}$ edição]

2 Reforma do ensino primário e várias instituições complementares de instrução pública. [X, II, 176] "Educar a indústria: Eis a fórmula racional da única proteção eficaz à produção industrial do país."

3 Pavilhão para a Exposição Internacional da Indústria e do Comércio, 1957-1960, no Campo de São Cristóvão, Rio de Janeiro 


\section{anexo 2}

\section{projeto de Flavio Motta para a exposição do Pavilhão de Osaka}

A sequência de pranchas que apresentamos a seguir corresponde ao conjunto original do plano de atividades proposto por Flavio Motta para o Pavilhão de Osaka. Trata-se de um "boneco" de um caderno para apresentação da proposta ao Itamaraty, originalmente no tamanho A2, contendo o esquema de organização dos textos e as imagens que explicam a organização das atividades no Pavilhão. A partir desse projeto, a equipe reproduziu as obras de arte e imagens escolhidas e produziu o caderno definitivo, utilizando as montadas segundo as indicações desse boneco e confeccionando os textos a partir de um conjunto de carimbos que Paulo Mendes da Rocha havia trazido do Japão.

As pranchas são organizadas da seguinte maneira:

> as 4 primeiras pranchas [I a IV] trazem um texto geral de apresentação dos temas que conduzem a programação

> a partir da $4^{a}$ prancha [número 1] - tem início a seqüência que corresponde aos painéis de exposição propriamente ditos, até a prancha número 31 .

> as 5 últimas pranchas descrevem as atividades complementares à exposição, que aconteceriam em paralelo. 

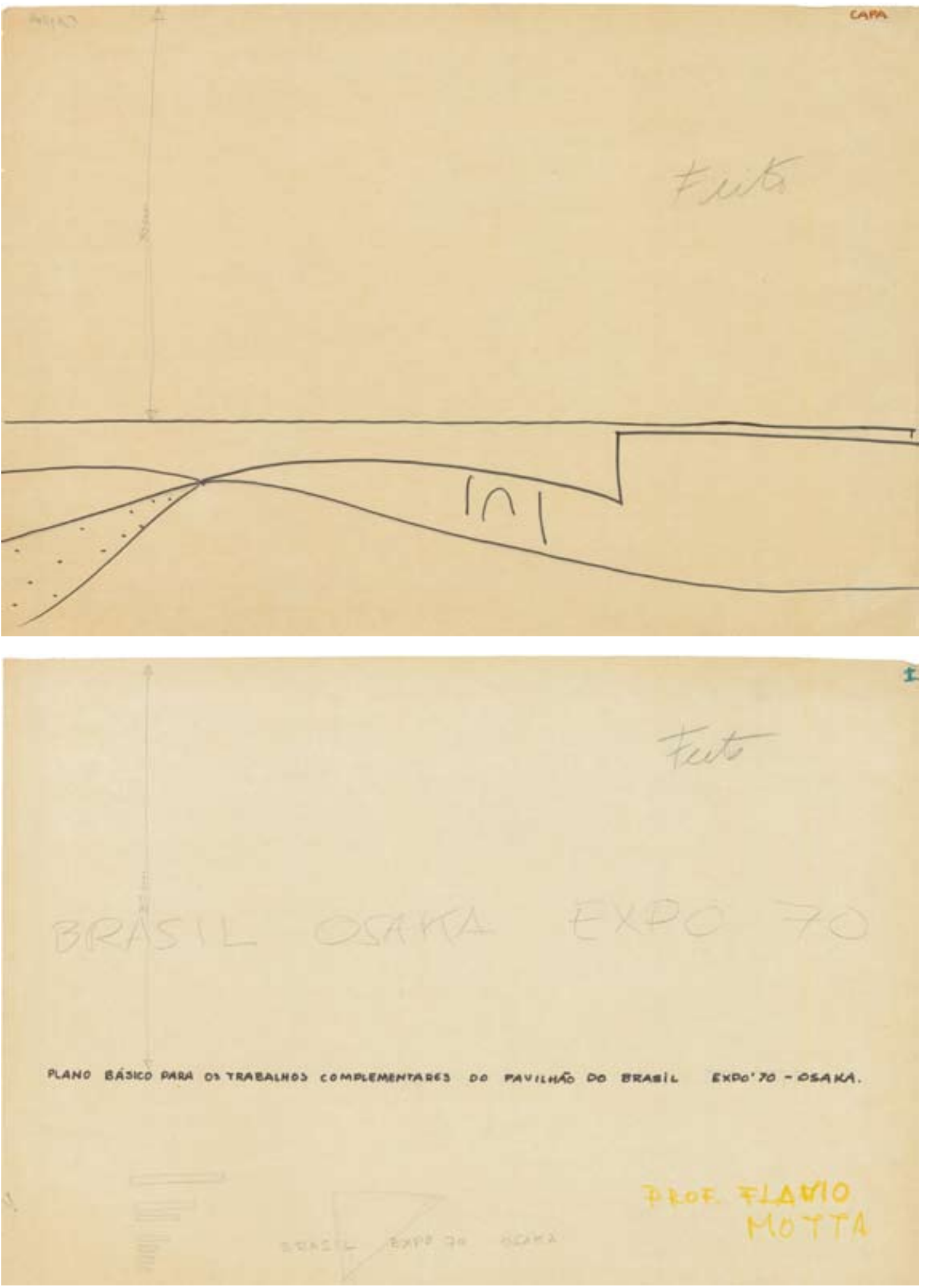
TEMA: DQOJETO DA CIOADE

A VISATO NO BRASIL DO DESENULUVIMENTO A DARTIR DA CIOADE MODERMA

A CONUIVÉNCIAA NO TRAAACNO:

ECONÖNICO-SOEIAC

CIENTIFICO

ARTISTICO.

- BRAsIL COMPARECERA' EM OSAKA EXPO'70 COM UMA CONTRIBUICATO DRÓLRLA AO UIVER CONTEMPORÃNEO, PROCURANDO ALINHAR-SE A UMA VISAÓ De coNJUNTO, DE H/RMONIA, COM OUTROS PAISES DRESENTES A AMOSTRA.

EXIBIRÁ UM PRONETO PARA O SEU OESEN. VOCUIMENTO, UMA VISĀ DE "MABITAT" CONTEMPORANEO, FRUTO DA RIQUEZAE DO AUANCO DA HUMANIOADE + vipe ciaAde como rorma de viUese. * URBANIZAFAó cOMO FENÖMENO SOCIAL

-O DESEJO DO HOMEM MODERNO, QUAC SEMA; A CONUIUÉNCIA NO TRABNLHO, NA DESOUISA CIENTÍFICA. NA INOVISTRIA.

NA convirioniancoming ARTE. E oesenailul tambe'm, que se conte DÉSG POVO A EXPERIËNCIA, QUGNAIO

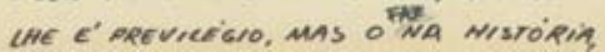



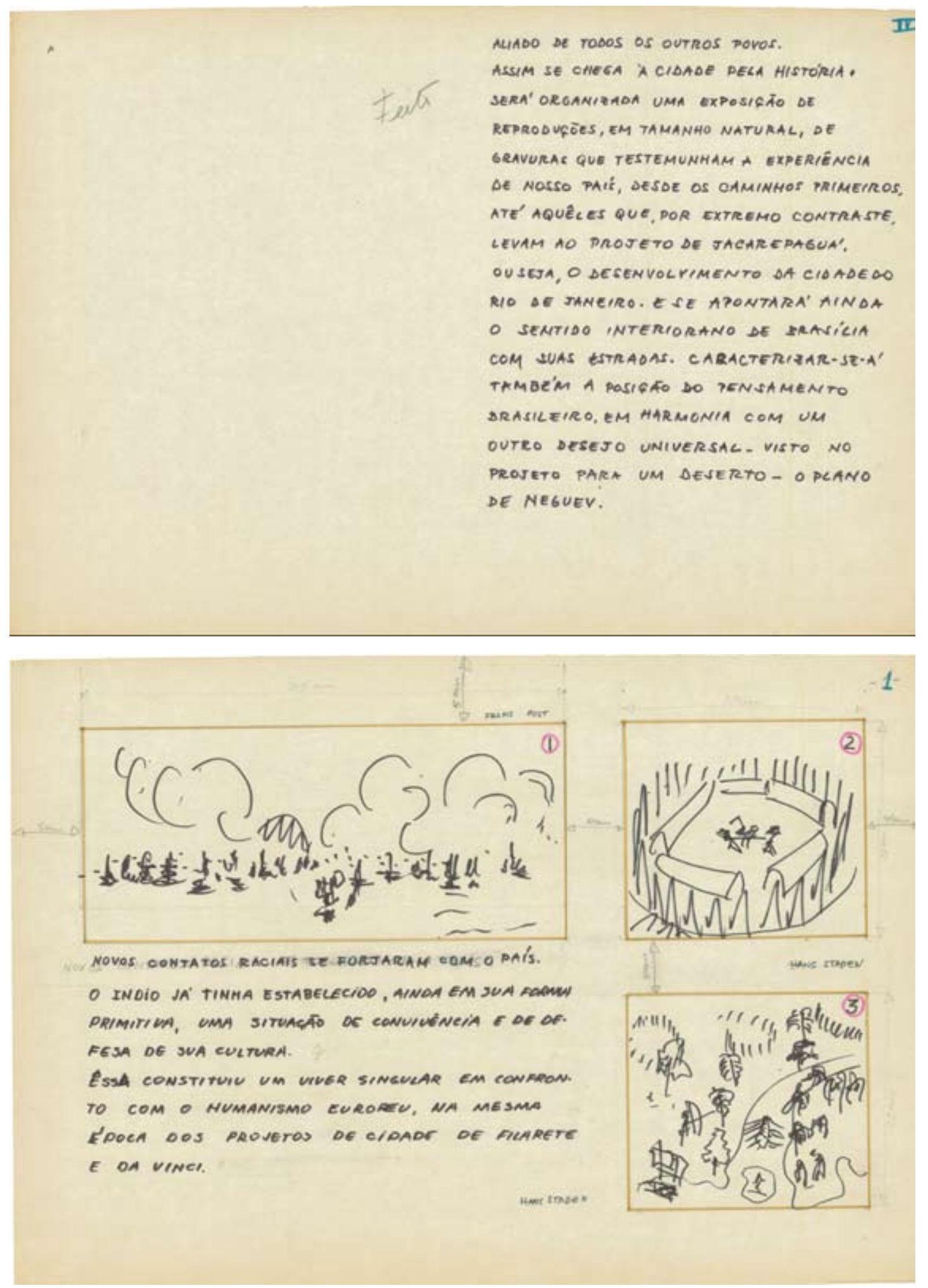


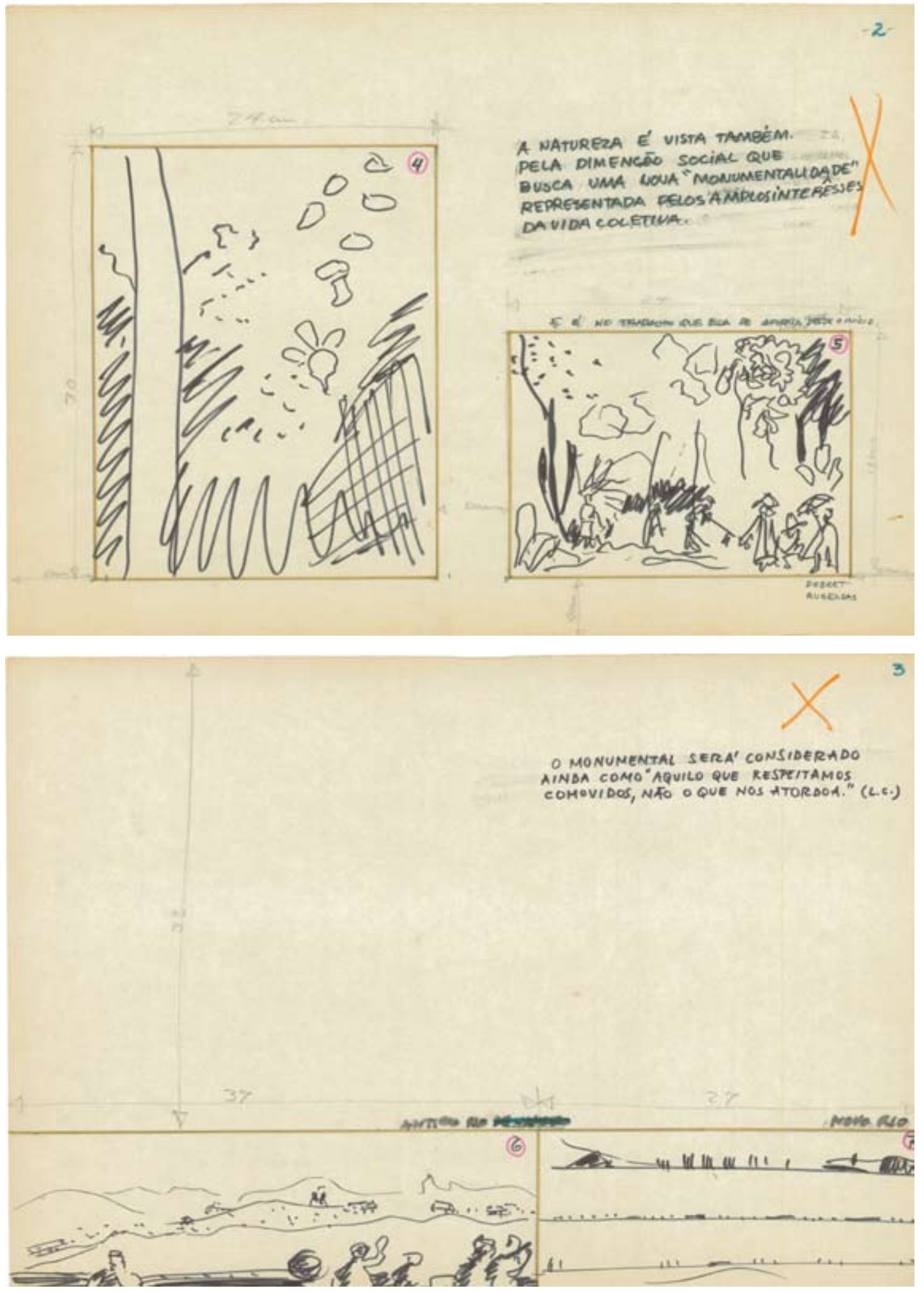



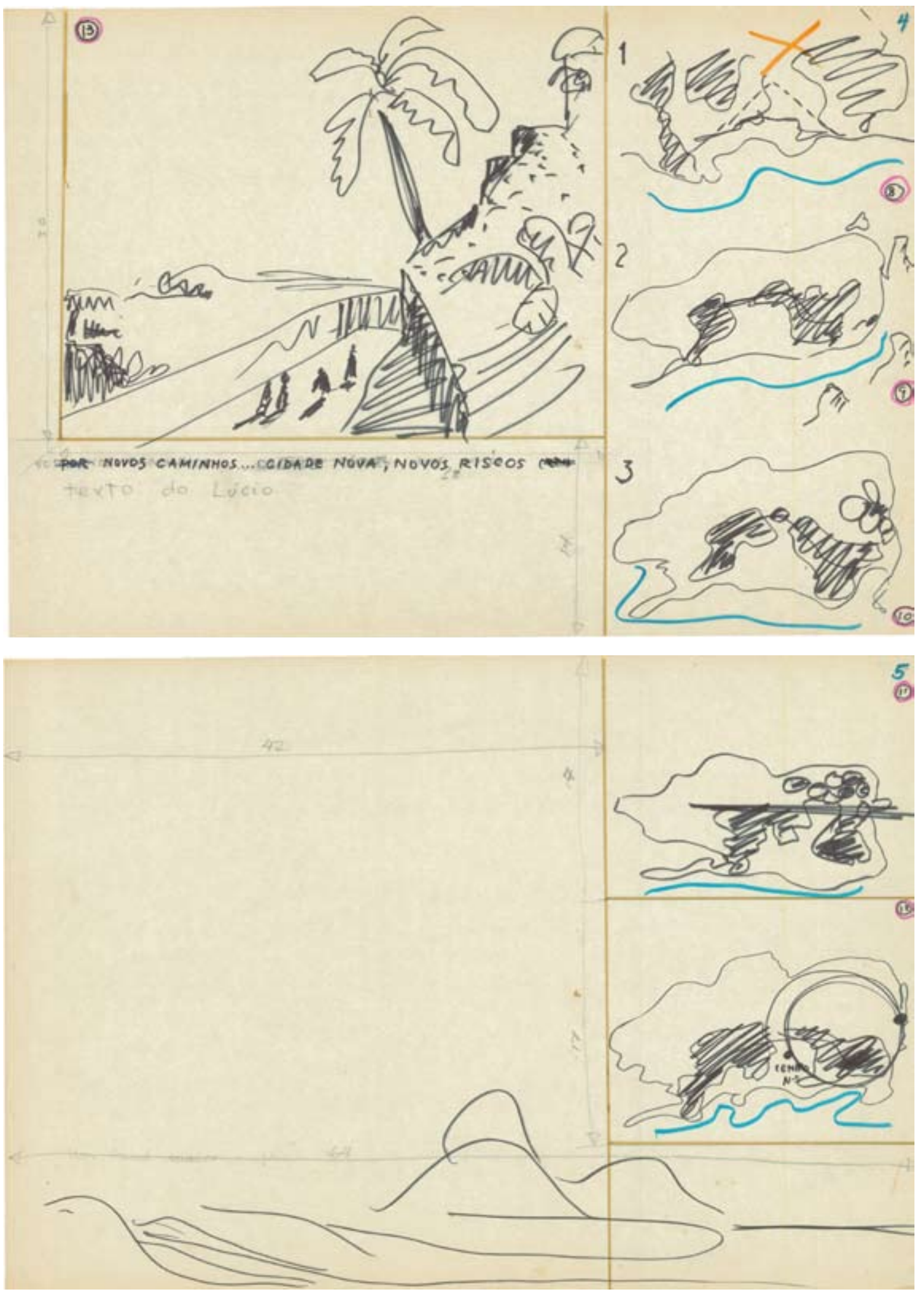

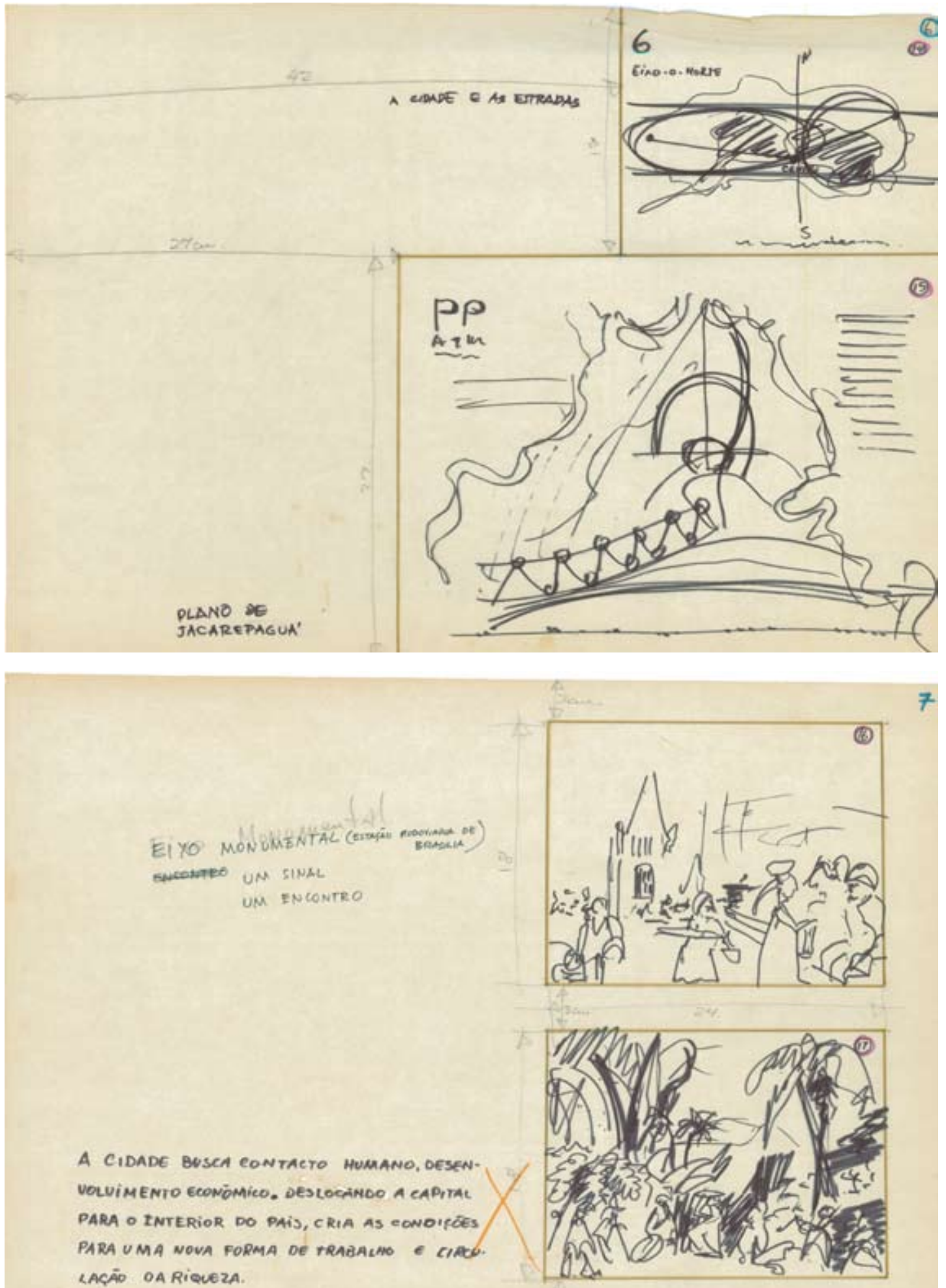

A CIDADE BUSCA CONTACTO HUMANO, DESENVOLVIMENTO ECONOMMICO. DESLOCHNDO A CAPITAC PARA O INTERIOR DO PATIS, CRIA AS CONOIFÓES PARA UMA NOVA FORMA DE TRABALMO C CIACO. ¿ACĀO OA RIQUEZA. 

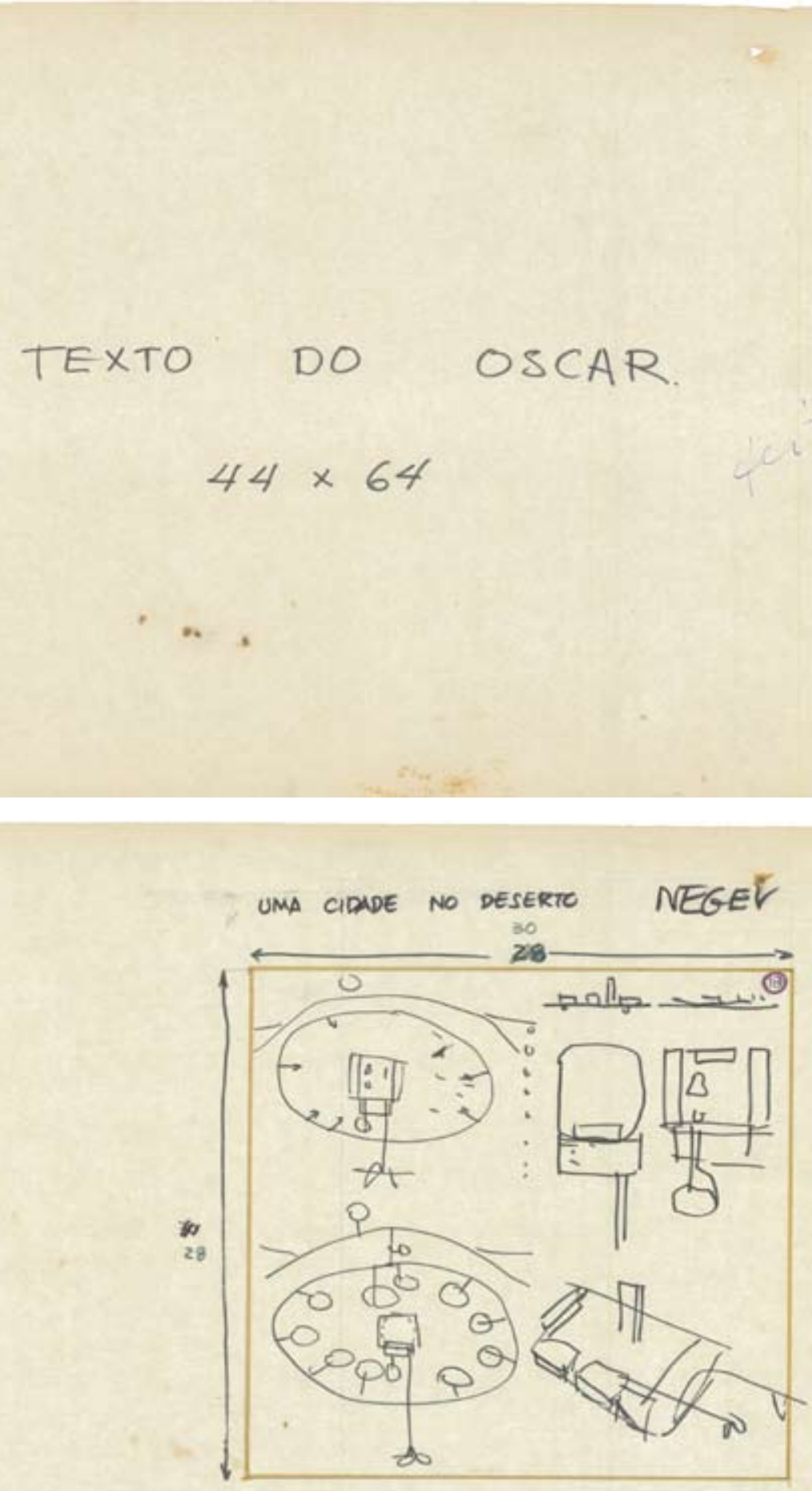

91 

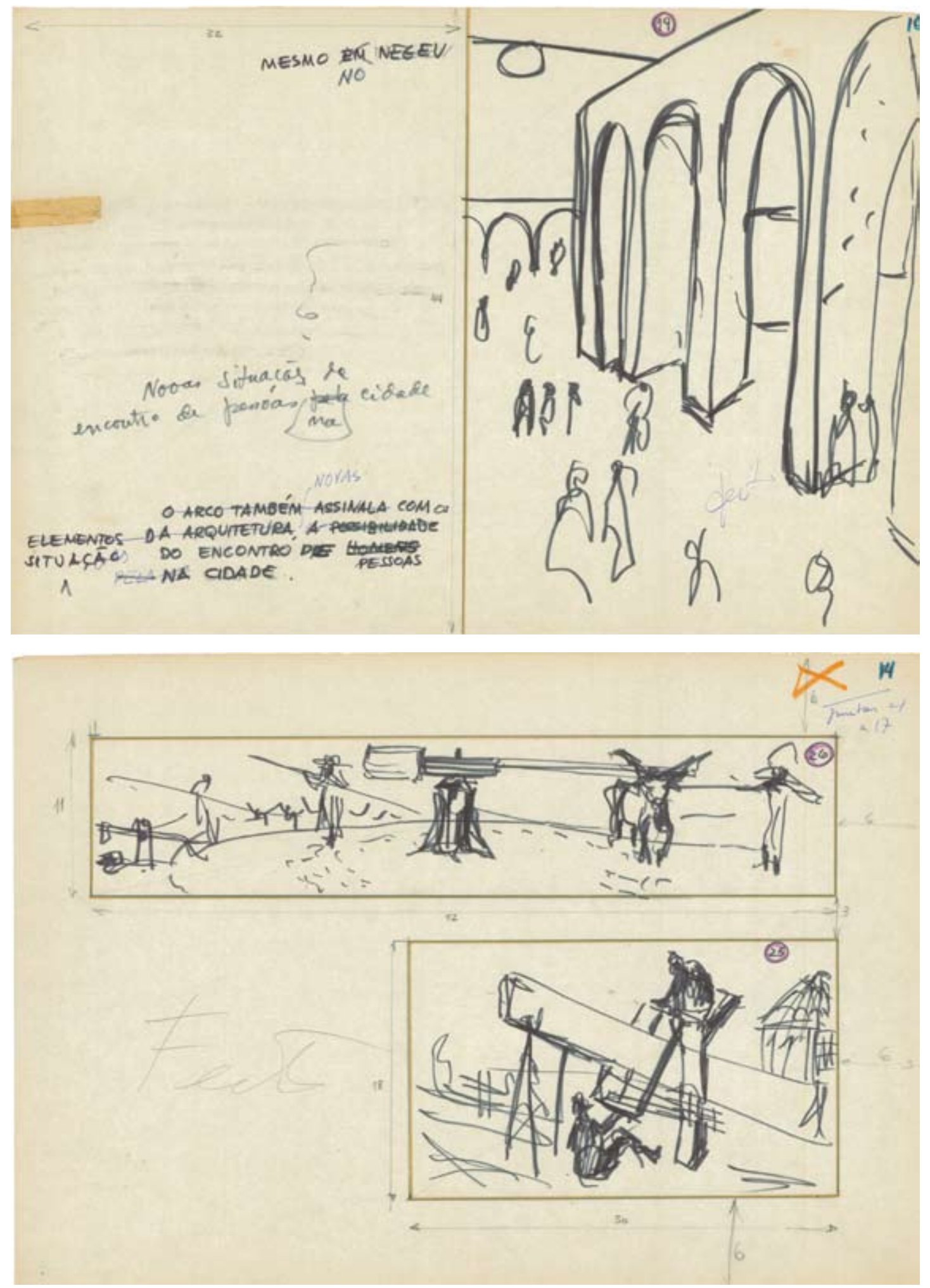


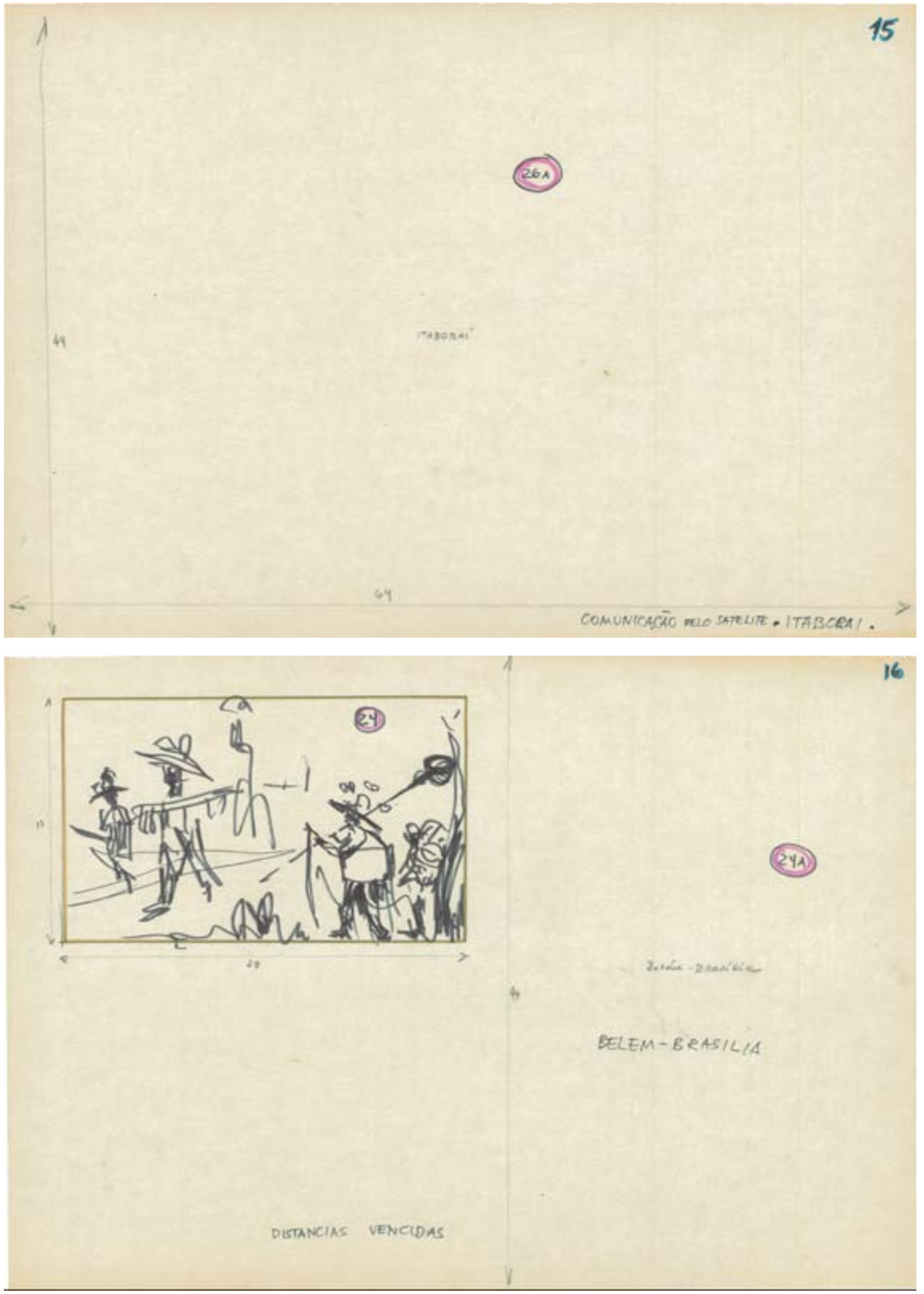



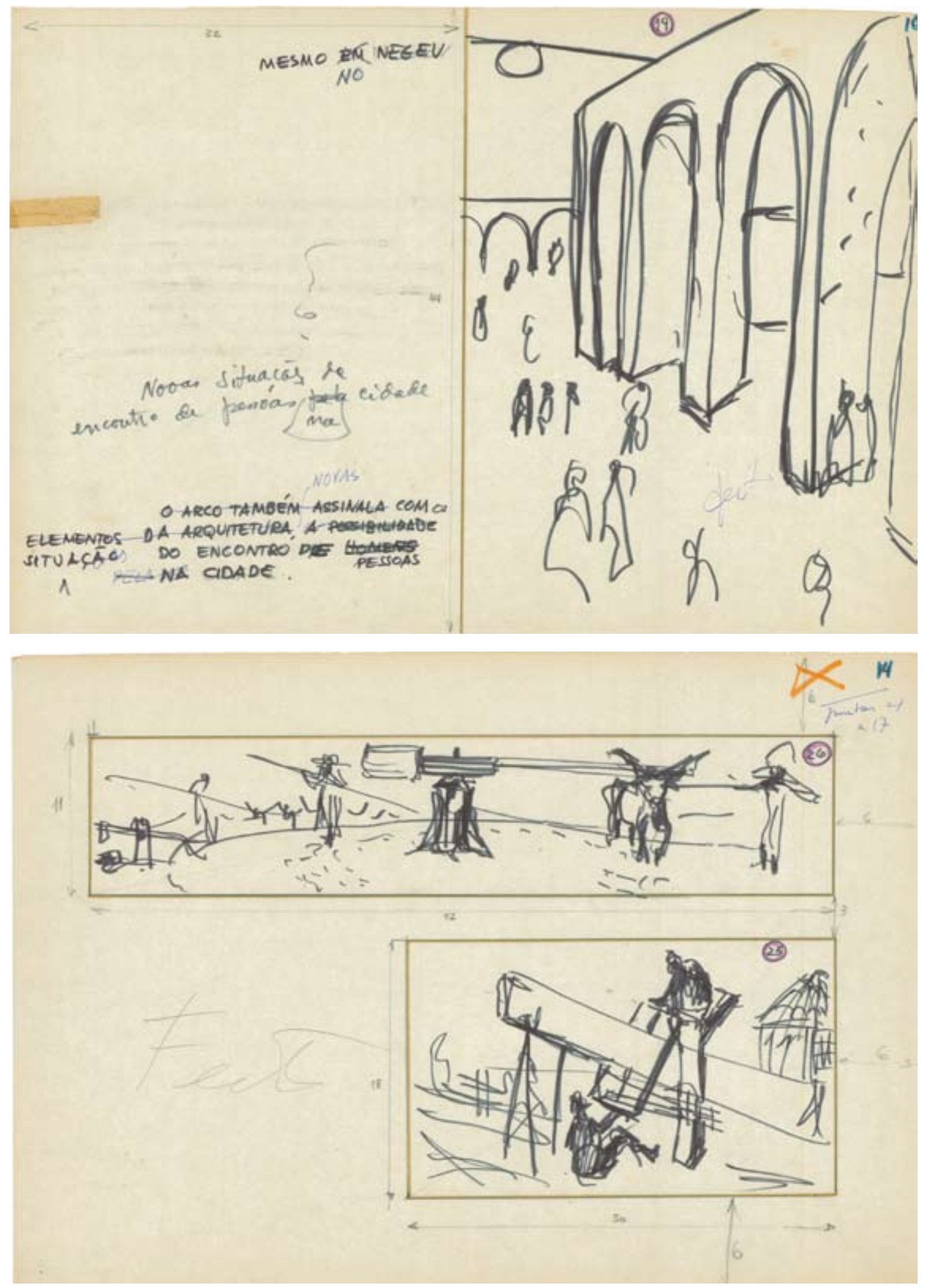

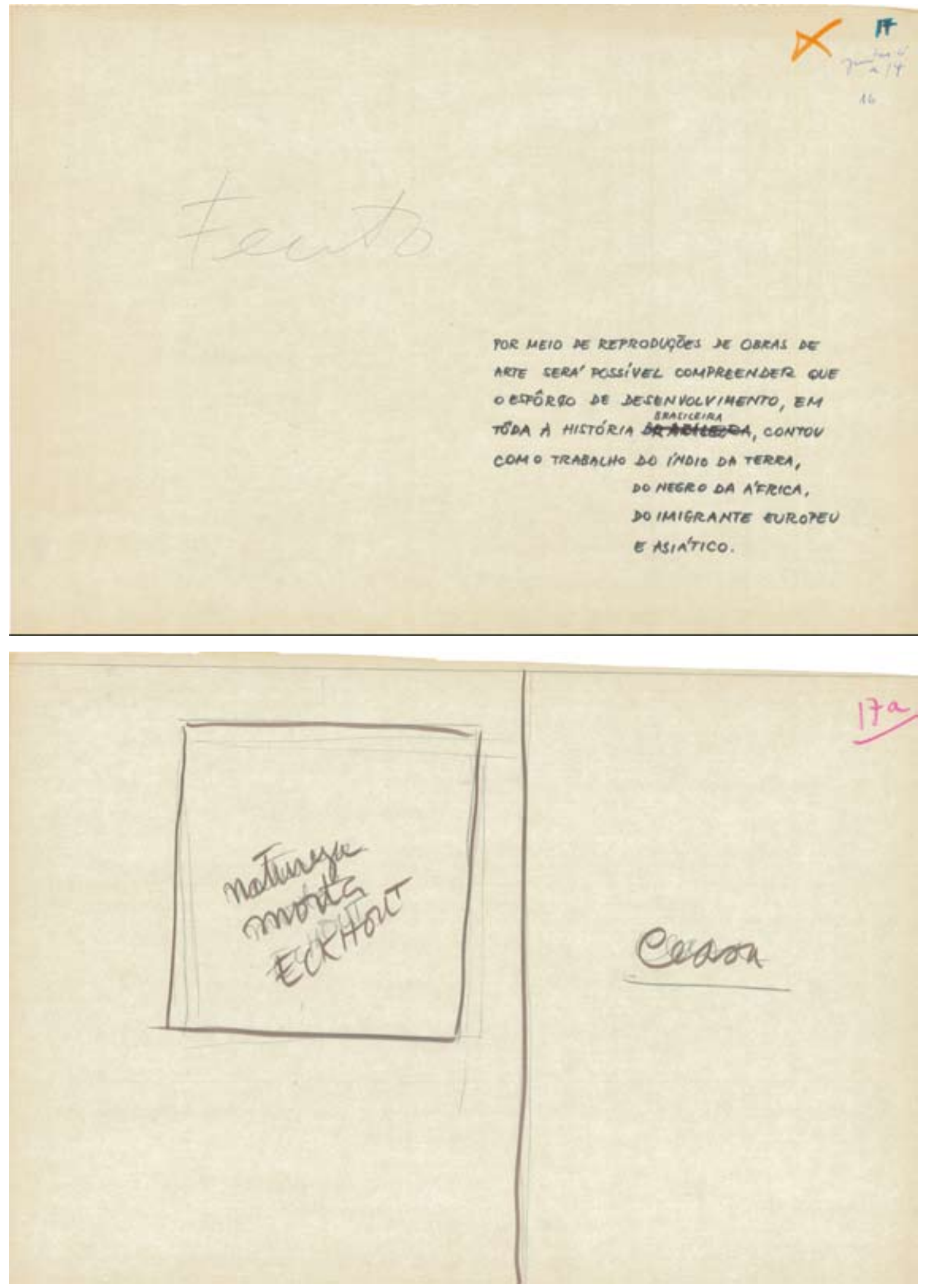


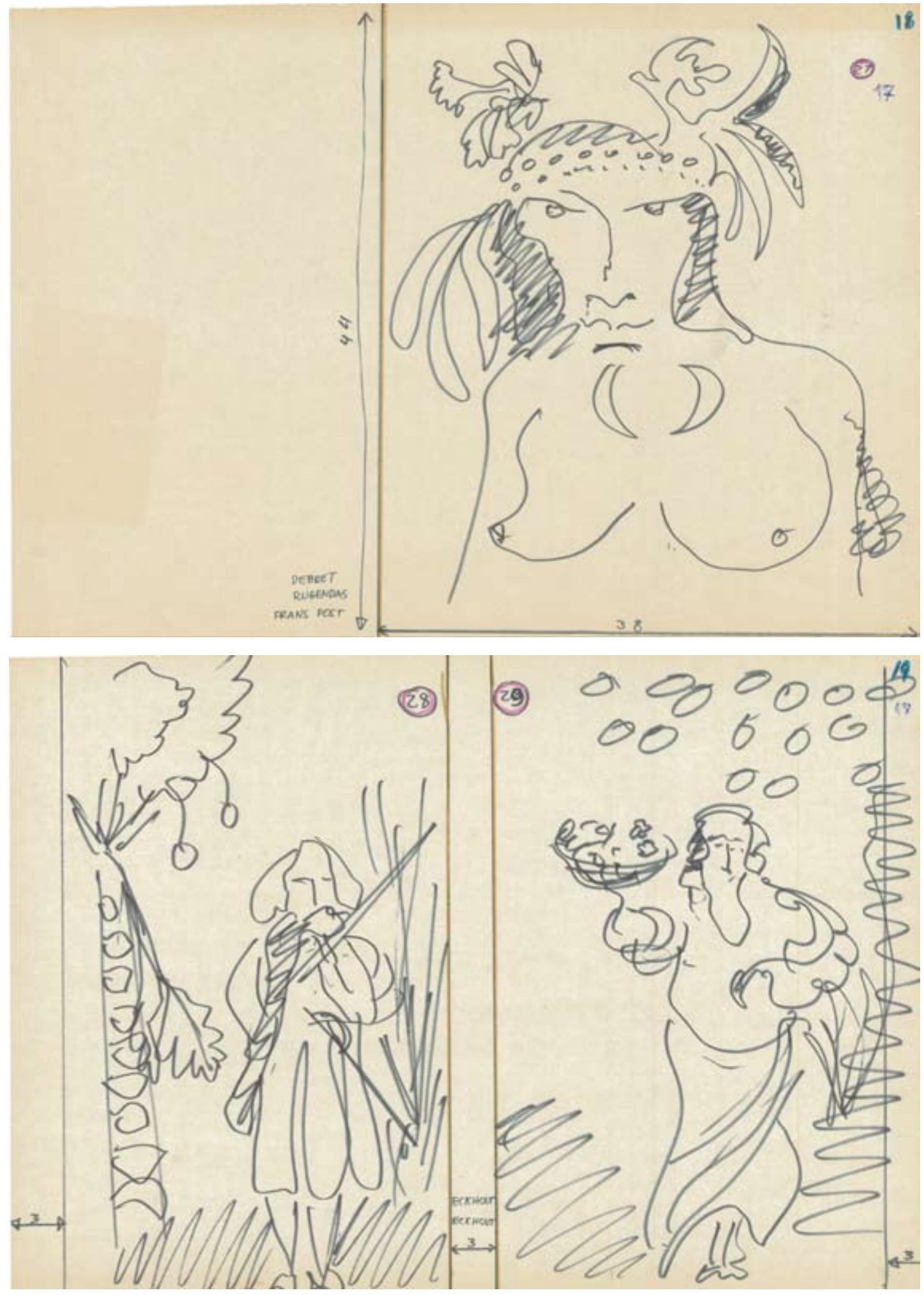



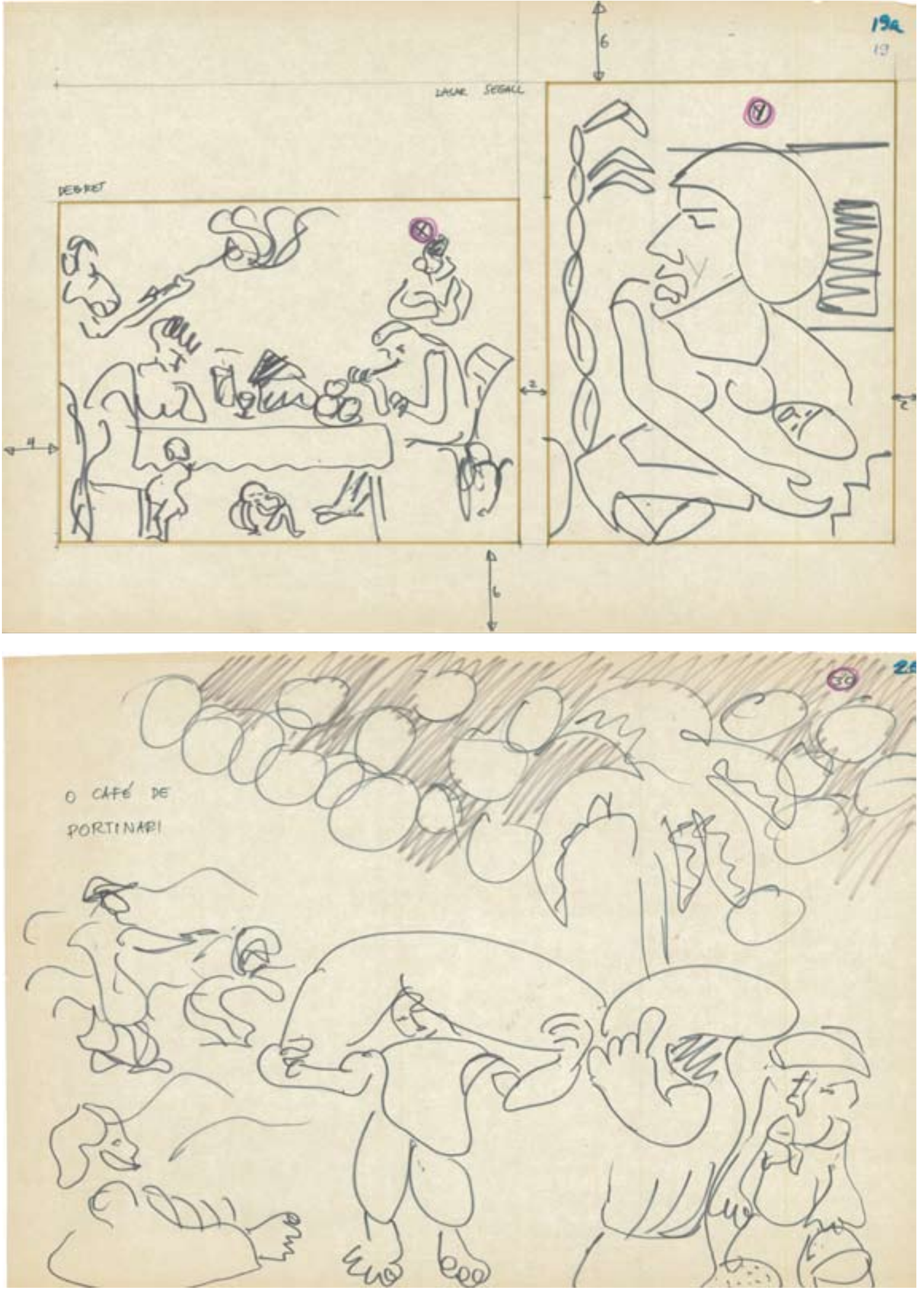

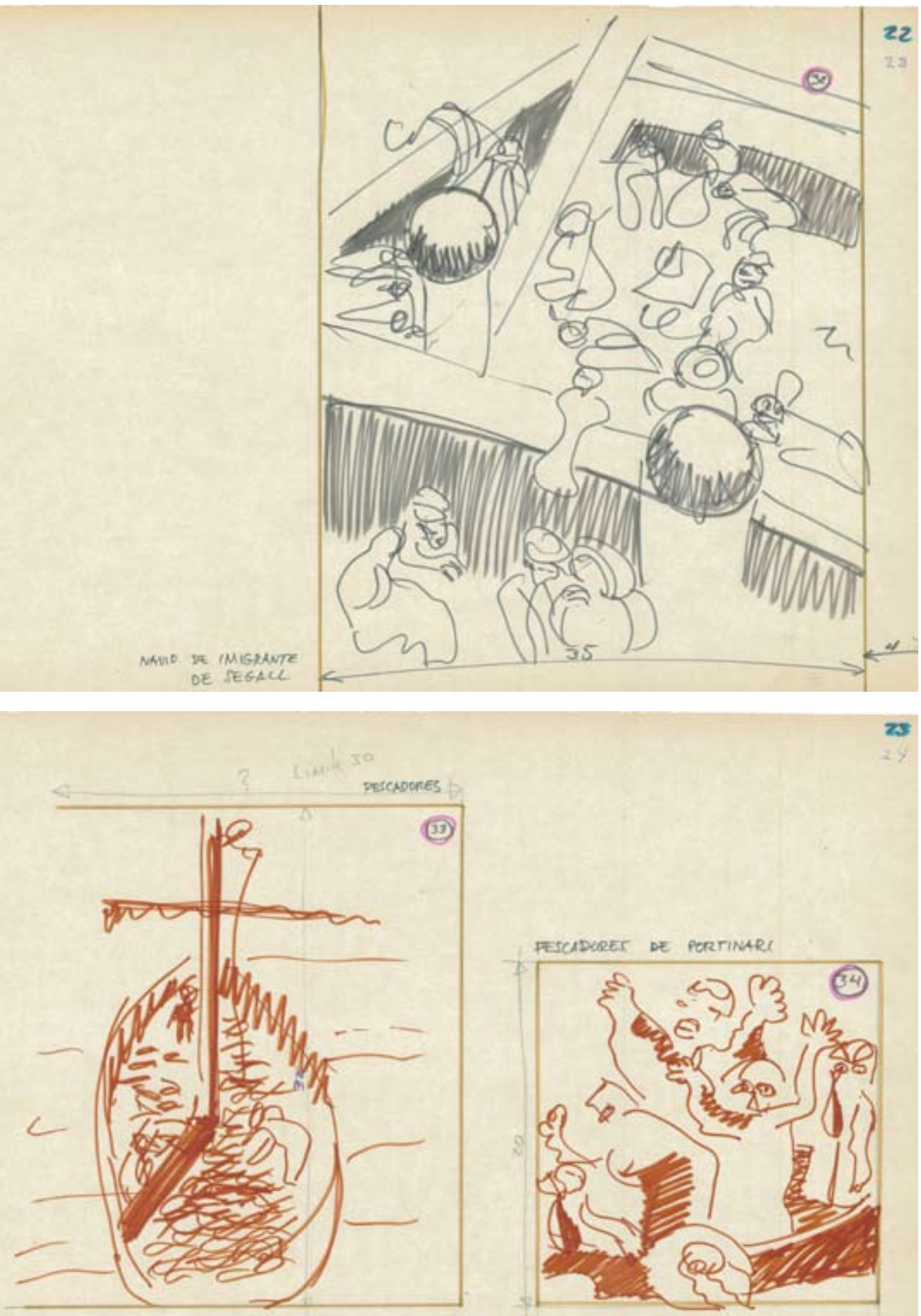

23

FESCIDURE DE PORTINART

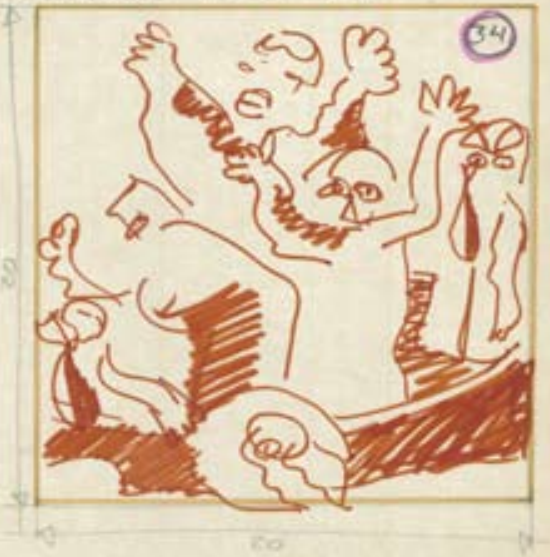




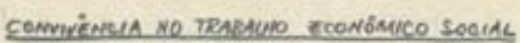

SERA'OREANIZADA WMA EXAOSIFTO DO PROTETO

SRASILEIEO DE INTERULAQT̃ DAS IACIAS

TRATA-AMAEONAS (MAAEIRA. GUAPORE'. ALEERE.

AGUAPEL PARA (UAA), COMO NOLUGT̃O SINGULAR

PARA A INTEERAEAOO DAS AKEEAS CONTINENTAM NO cOMÉRCIO MUNDIAL.

TROTETE DE GRANDE ENVEROADURA, HFIRMAGÁO DA CAPACIDADE DE UTICIEAET̃O DOS HAIS AVANGADOS RECURSOS TÉ́CNICOS, ADRE AO PAI's UMA SEGUNDA COSTA SOBORE UMA PAISAGEM RICA EM TOOOS or ASPECTOS DA PRODUTIVIAADE NACIONAL. AEMONSTRA QUE - pars se afirma com andias proportar.

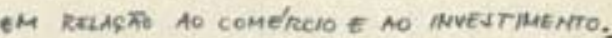
TÉ A DESCOBERTO VA'RIOS SETORES DE ATIVIDADE-COMUNICAERO, PLANESAMENTO, SAÚDE, AGRIOULTURA, ENEROIN ATEMMTC -

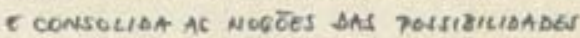
DE UMA RELAGT̃ HUMANISTICA NO TRABACHO.

A OVERSIFICAEĀO DA ESTRLTURA HOUSTRIAL SE ARATIA VISANDO SETDReS DE DENS AE PRODUETTO (QUIMICO, METALÚR GICO, MA OUINAS

E EqUIPAMENTOS) ERIGE OBRAS DESSA AMPLITUDE.

COCOCA AS RESERVAS DE MATERTIAS PRMAAS

C A POISIBLIAADE DE DISTRIBUIETO 20 PROOUTO Mas acessíveII, NUMA ESCACA JPASTLEIRA, IM COMONICAQT̈O DIRETA COM OS PORTOS DE MAR.

LEA OS PRINCIPAIS CENTROS MUNOIANS. DRETAMENTE, A ARREA CONTINEATAL DO PAIS.

ESTE MOTETO CONCRETIEM UMA FORMA DE "PROTETAR" A INDUSTRIALIZARÃO, ATE' AGORA INSCLADA NO CENTRO-SUL

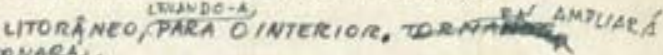
E TLENARS

SOLIDARIO E AMPLMRA O ESPAFO ECONÖMICQ 

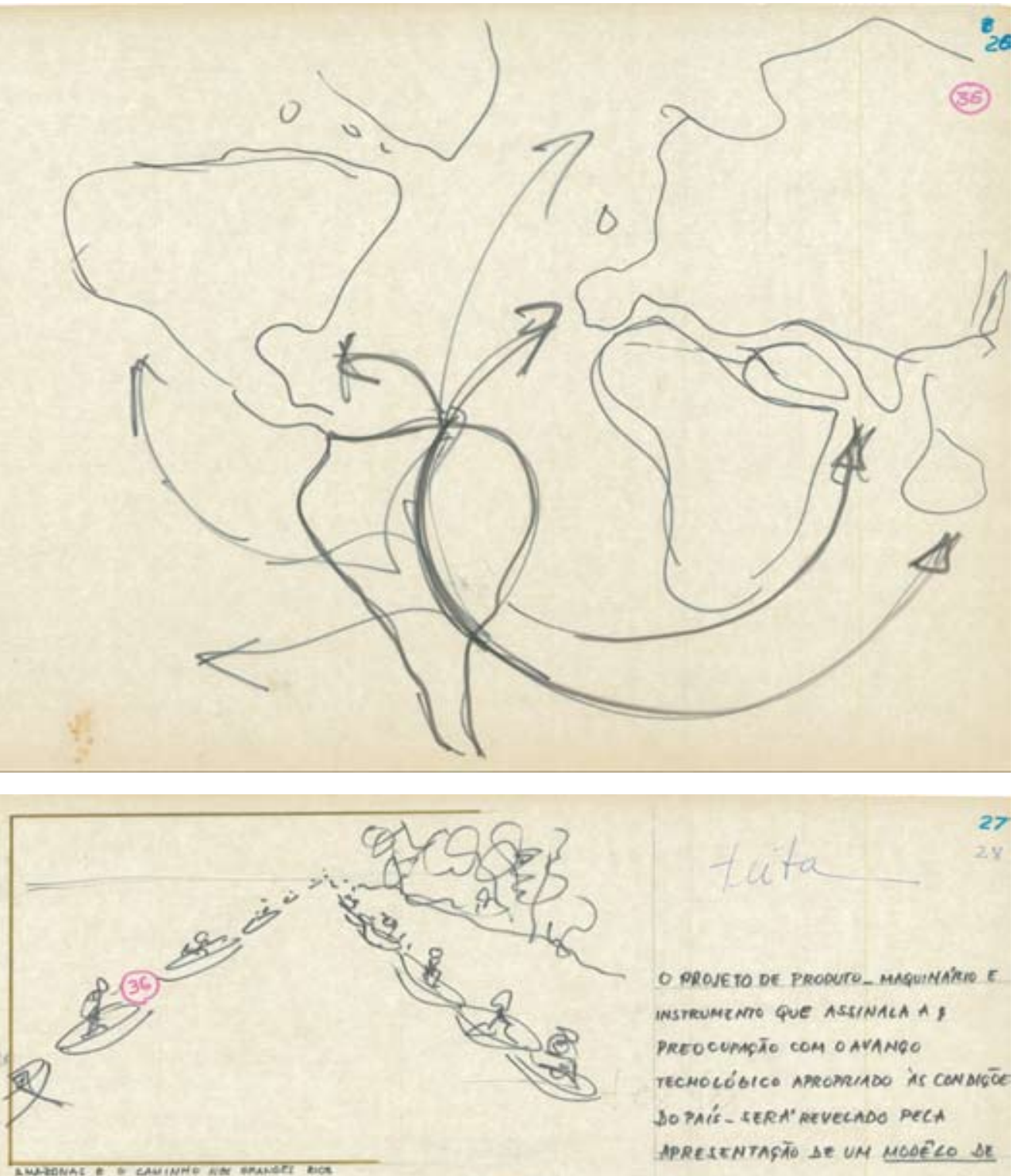

S.FANETSEO MAUTO

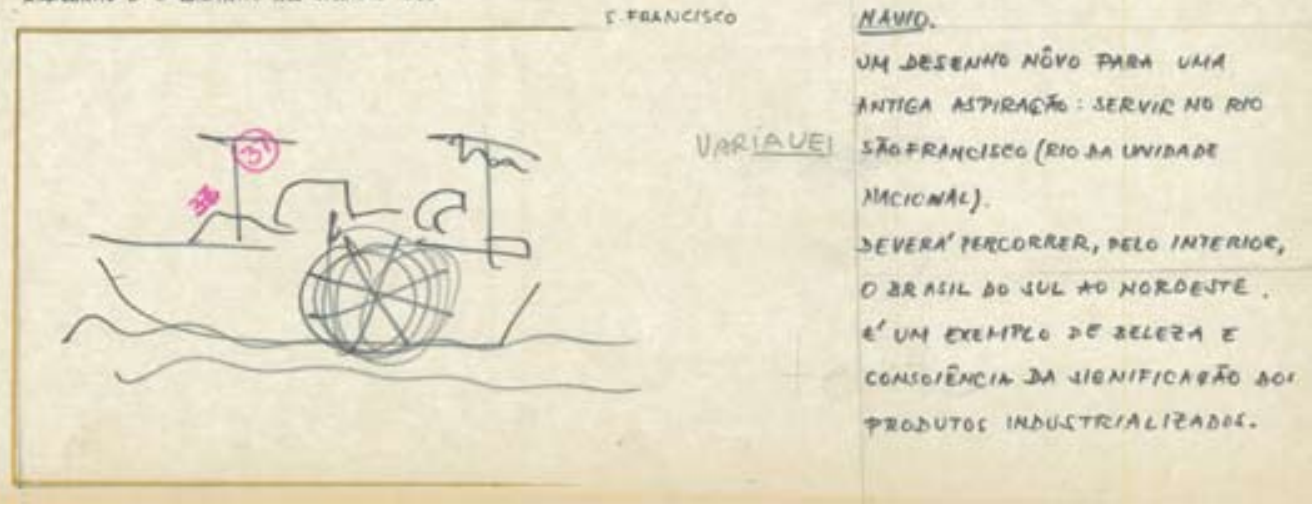

O PRONETO DE PROQUTO MNQUNARRO E instrumintro que AsSINACA A, PREOCUMATTO COM OAVANQO

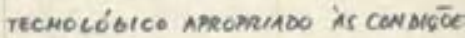
DO PAÍ́ - SERA' REVECADO PECA APRESENTAGT̃O DE UM MOQẼLO AE UM DeSento Nôvo Preat UMA ANTIGA ASPIRAGTO : SERVIC NO RMO STO FRANCISCO (RIO MA UNIAADE MACIONAC) SEVERA' PERCORRER, DELO INTERIOE, O ARASIL DO SUL to NORDESTE. E'UM ERHre se seLEZA E

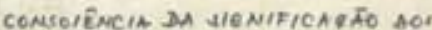
PTODUTOS INDUSTRIALIZADOS. 
O TRARALTO CIENTIEICE CRIAPER

DEMONSTRA QUE A CIÉNCIA FLORESEE COM A OLOADE, NA UNIVERSIDADE, NA INAÚSTRMA, E RESPONDE A TODO IM ESFBRPO DE CONATRUERO DA VIOA MODERNA.

SERA' EWIAIDA A 'BOLA DEFOEO" UM TROTETO QUE SE CUMPRE APC'S 22 ANOS DE COOPERAGÃO ENTRE SRASILEIROS E JANONESES, ATINEINDO RECONHECIMENTO UNIVERSAC.

A "BOLA DE FOEO" DESTACA A IMTORTÁNEIA DO ATOMO PARA OBEASIL, NOTABAMENTE NO DEVENVOLVIMEMTO INOUSTRIAL, DELO CONHECILENTO DA DINRMMICA DA PRÓPRIA MATE'R/A E SUAA POSSIBILIDADES DE TRAMSFORMAGFO PARA E PELO HOMEM. A CIÊNCIA ATÉMICA MOSTRA, INCWUSIVE, A SUA IMEDIATA APLICAEILIDADE DENTRO DE pROTETOR QUE DÄO UMA OUTRA DIMENSTO AS CONDIGÖES DA VIDA URTANA. SERIA O CASO DA AVALIAÇÃO DO REGIME DAL GACIAS HIDROGRA'FICAS, TELA DISSEMINARR̈O

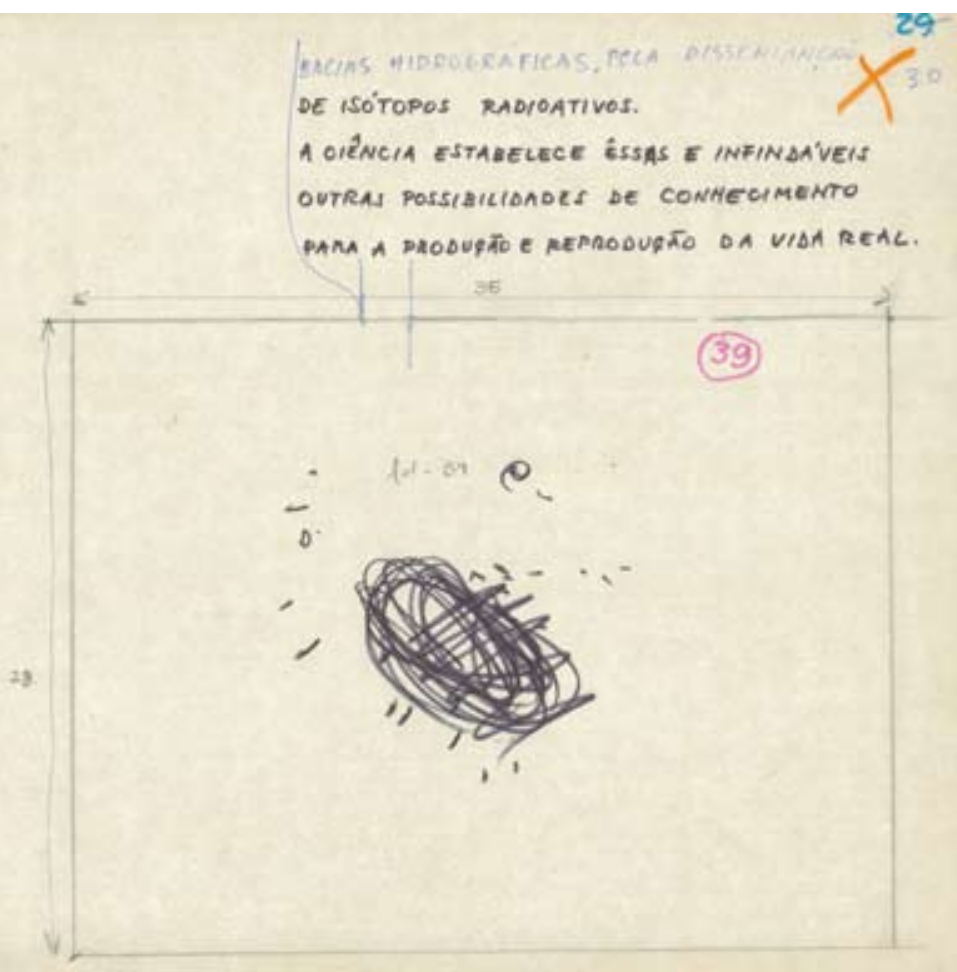


DO MESON

G' TOOA UMA HISTÓRIA DE HIPÓTESES DE TRABALHO, CÁLCULOS E EXPERIÉNCIAS FEITAS POR JATONESES E TRASILEIROS, TRABALHANDO JUNTOS DESOE 1947. ¿ A DEMONSTRAgÁ, tamá́m, Das EQUIVALENTEIAS ENTRE CALCULO, EXPEREMCIA E * PERIPECTIVA CIENTÍFICA, FRUTO DE UHA NOVA VIST̈O DO UNIVERSO.

AESINALA AINAA COMO O TRABALHO CIEATIFIFOO CRIOU NOVAS SITUAEOESS CRIATIVIDADE: EM CHACALTAYA A 5.200 METROS DE ALTUR A, nOS ANOES, (A PARTIR DE 4963 ) ENTRE INDICENASOS CIENTISTAS CATTES E FUTIMOTO -A CONSAGRAFÃ NO CONGRESSO DE RUDAPEST. UEU RECONAECIMENTO UNIVERSAL.
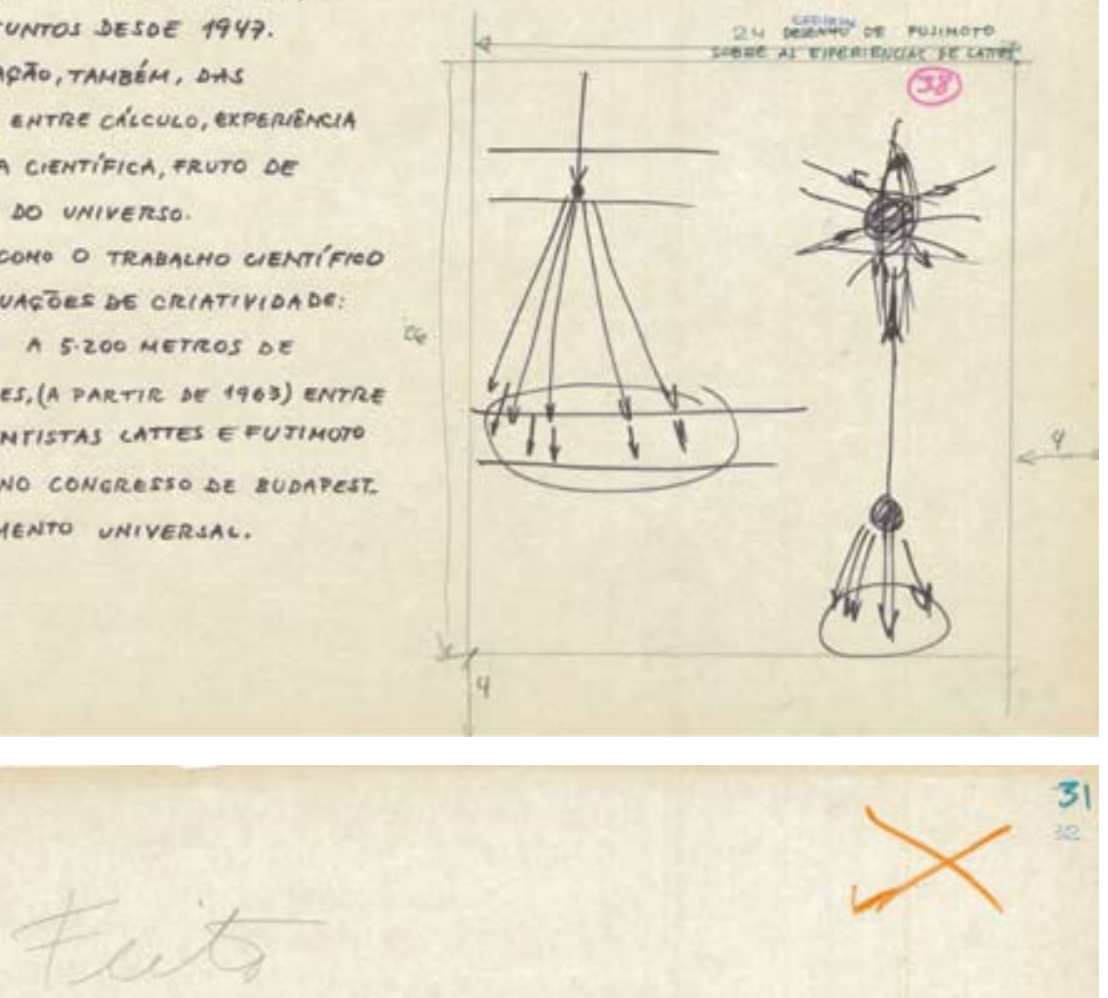

31

DESOE A CONFORMAEAO DO MISO ATE A COBERTURA, TODO O FUNCIONAMENTO DO PAVILHFO PRESSUPJE UM RITMO DE RELACIONAMENTO COM SENTIDO TRÓDRIO, ISTOE', UA'RIAS FAIXAS DE INFORMAGĀO E COMUNICAGFO DE DENSIOADES DIFERENTES, COMO SE FOSSEM PLAMOS HARMÔNICOS QUE FAZEM VALER CAOA PARTE OU O TODO SIMULTANEA E SUCESSIVAMEMTE. O FREQUENTADOR DO PAVILHÃO PERCEOERA ESTAS RELACOOES SEM PERDER A NITIDEF DOS ELEMENTOS VISUAIS, ESTACIAIS, HUDITIVOS E MESMO DE SEUS COMPANHEIROS DE CAMINHADA. 

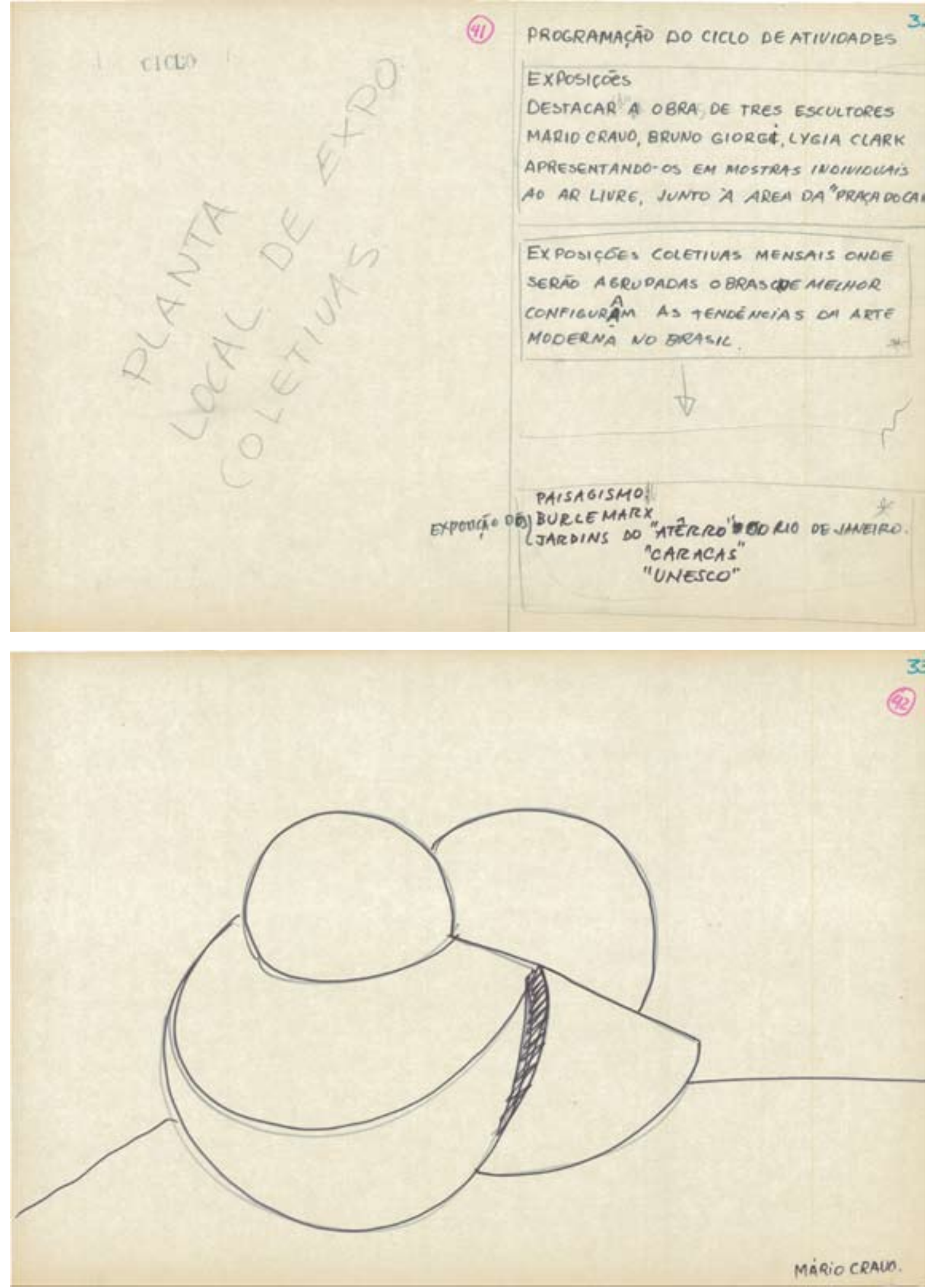


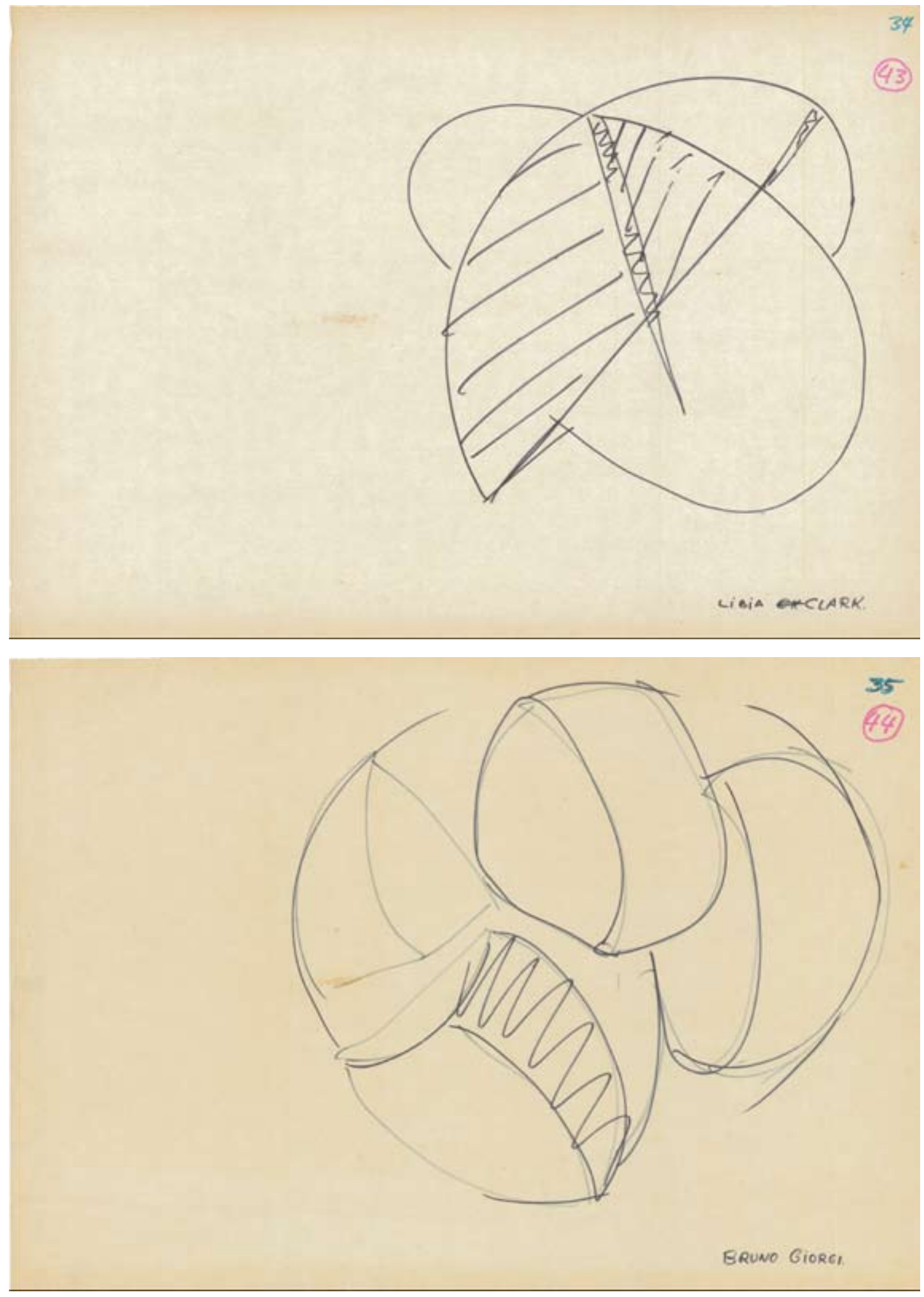


CINEMA E MÚSICA

$\rightarrow \rightarrow r$

as PROgRAMAGóes mUSTOAIS SERTO

OROANIZADAS COMO CONCURSO DO MUSEU

DA IMABEM E DO SOM, ABRANGENDO

A PARTICIPAFAO DO aRASIL NO" FESTIVAL LATINO AMERICANO DE MÚSICA POTULAR". DISCOS E"TARES" DE MÚSICA BRASILEIRA POPULAR E ERUDITA OOMPLETARÃO D AMBIENTEPS SONORO DO PAVILHXODURANTE TODO O PERIOODO DA EXPO.

SERTO AINAA PREVISTOR ESPETÁCULOS AO VIVO- DESDE AS ESCOLAS DE SAMAA A "MISICA DE PESQUISA".

a programagäo do setor de cinema PODERA' TAMAÉm CONTAR COMA.

ACESSORIA DA CINEMATECA E DOS Nano

ESTECIACISTAS COMO ALMEIDA SALLES,

PAULO EMILLO SALLES OOMES, JOAQUIM

PEDRO DE ANDRADE...

\section{noneswor LIVROS OEARTE}

APRESENTAR COLEPDES DOS OEH BIELIÓ́RLLS, DE JÚLIO PACIELLO E OUTROS WVREOS TIPO "AMARONIE" DE SCHULTHEISS, "ORASIL" DE

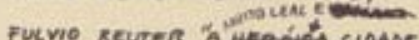

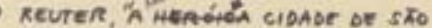
SEBAITI X OAstro maia, pue popereño ten consultanes NO CHeA ANEXO DO TTAMARATY OU NOAUOTO'R/O. FOTOGRAFIAS MARA EXPOR I

of TOSE' hedeIROS

Qquinerot

pierre VERGier

FULVIO REUTER

EMIL SCMULTHEIIS.

COMO CONSULTOR PARA A PARTE ICONOERAFICA DE MITOKRIA SERIA RECOMENOAVEL A CONTRIBUIGT̃ $\$ E S$ GILAERTO FERRAR-E rU ELIOAFÖES LYGIA MUETNS COSTA.

As PUDLICAGótes SERT̃O MROGAAMADAS DENTRO DE UM PLANO DE NORMALIZAGFO QUE LAES ASSE GUR QUALIDADE GRÁEICA ERACIONAL DIVULGA GFO. CAPAZ, INCLUSIVE, DE ABRANGER OS VA'RIOS ELOCOS 
anexo 3

documentação da obra do Pavilhão de Osaka

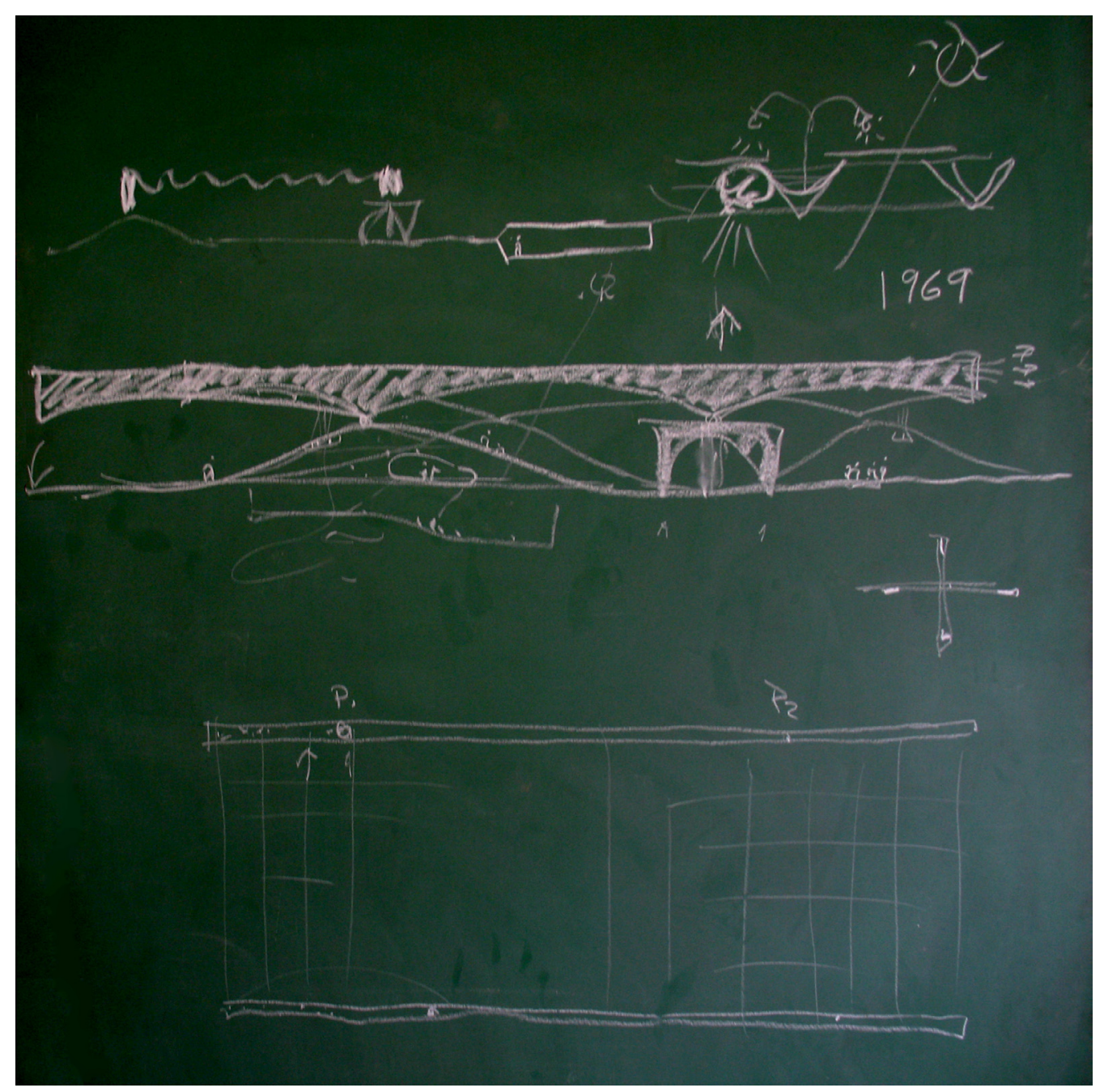



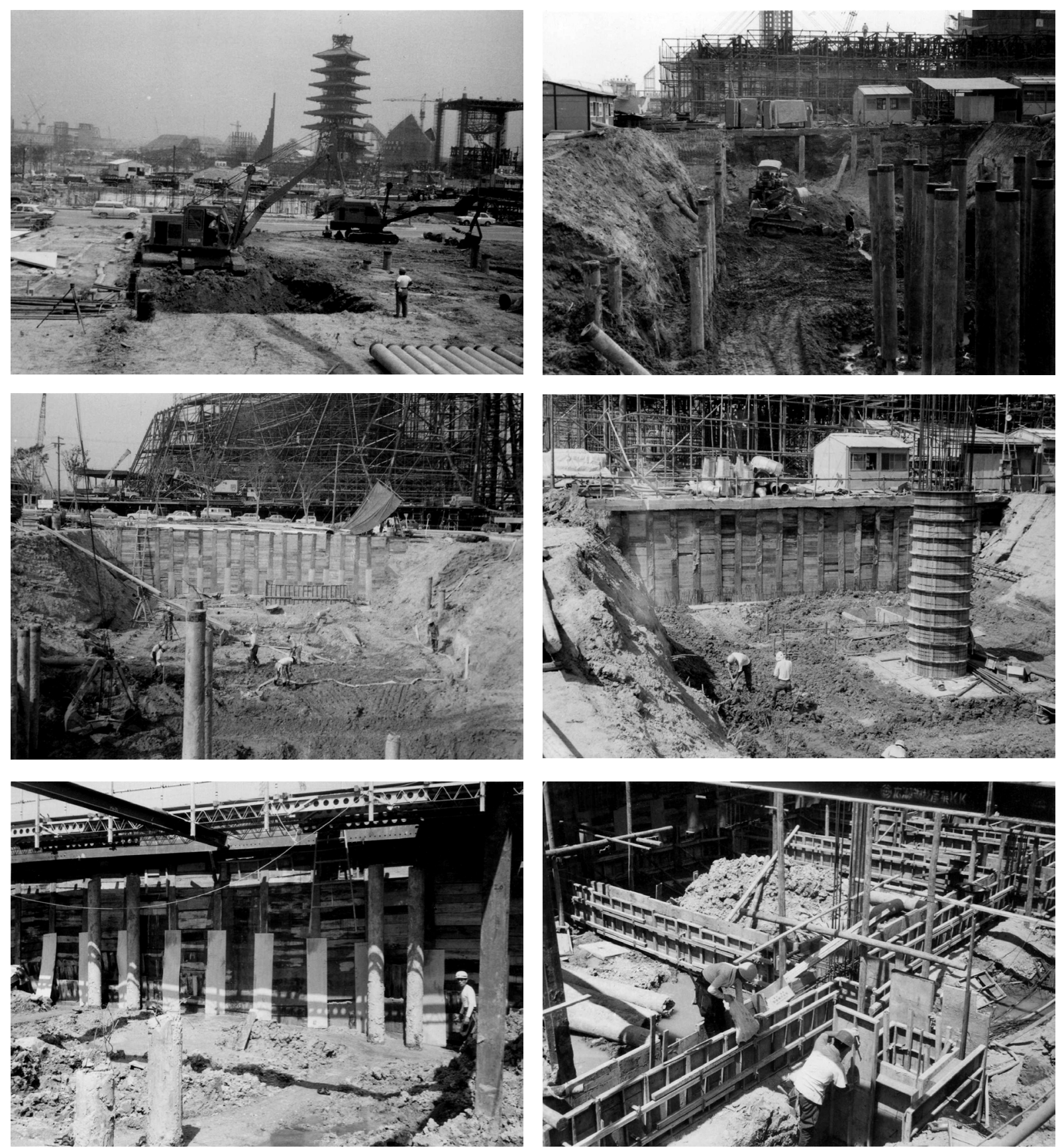

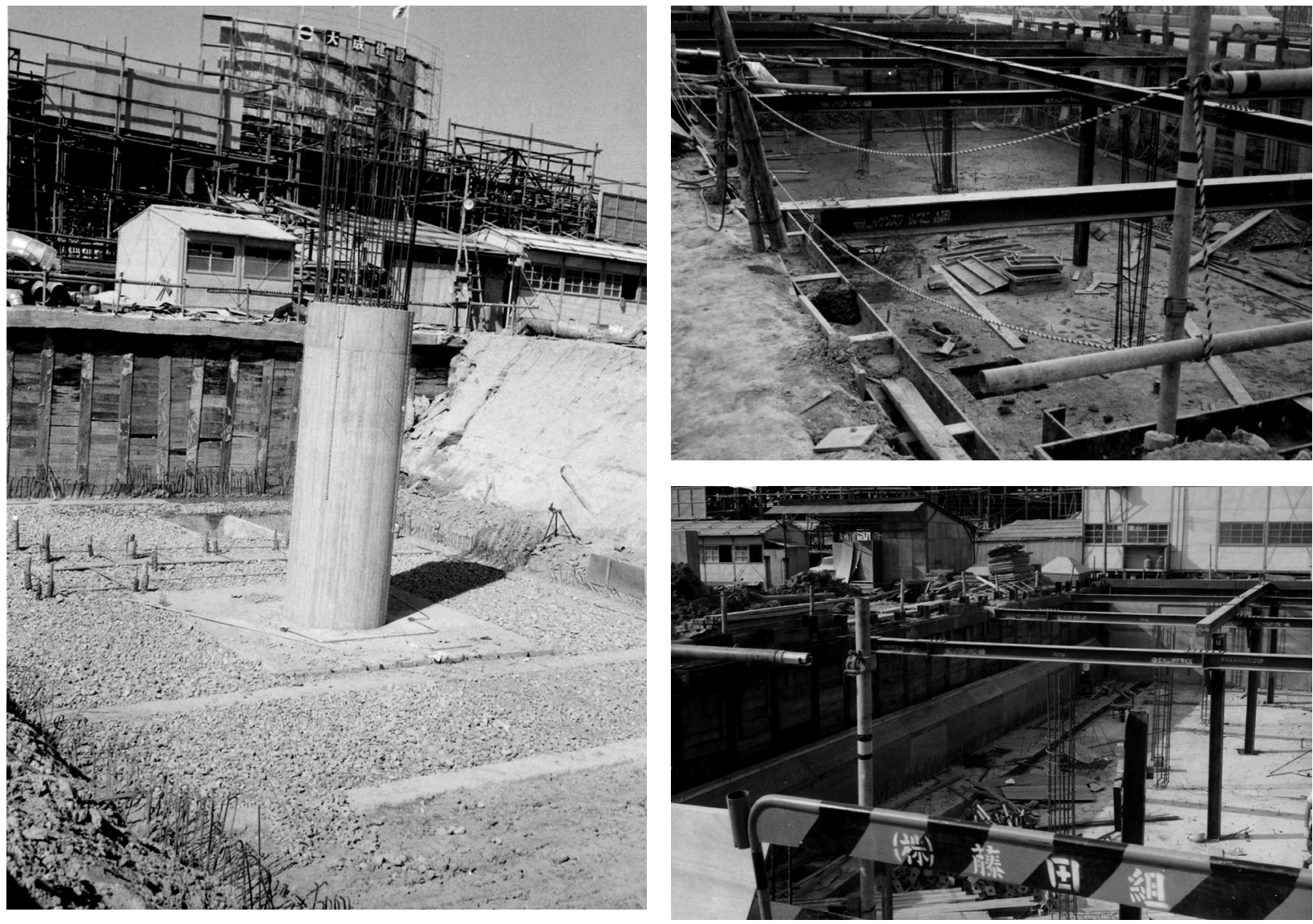

Início das obras

1. movimento de terra, início da escavação da área de espetáculos.

2. escavação e contenções da área de espetáculos, ao fundo construção do pavilhão da Checoslováquia.

3. formas dos muros de arrimo da área de espetáculos; ao fundo a construção do pavilhão da URSS.

4. formas do muro de arrimo e do pilar P3 na área de espetáculos.

5. escavação das fundações do Itamaraty.

6. formas das fundações do Itamaraty.

7. pilar P3 já desformado.

8. laje de piso do anexo do Itamaraty já concretada.

9. parte do arrimo inclinado do Itamary concretado

10. montagem da forma da laje de cobertura do Itamaraty.

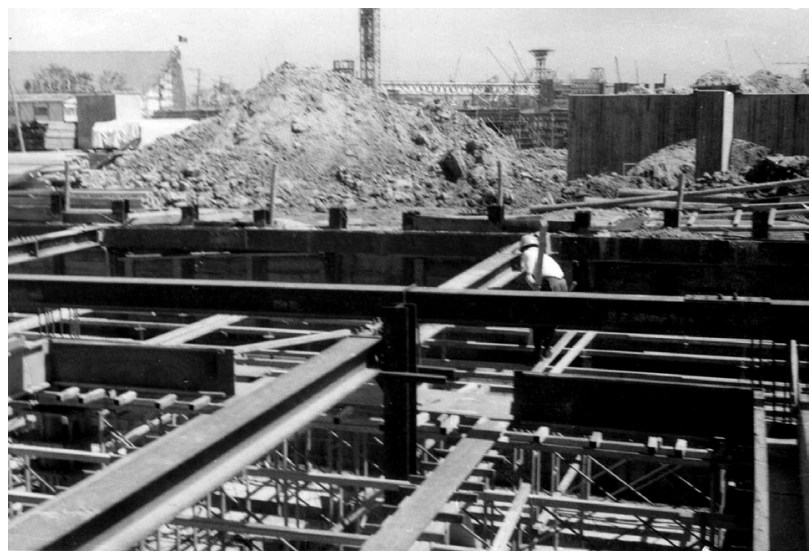



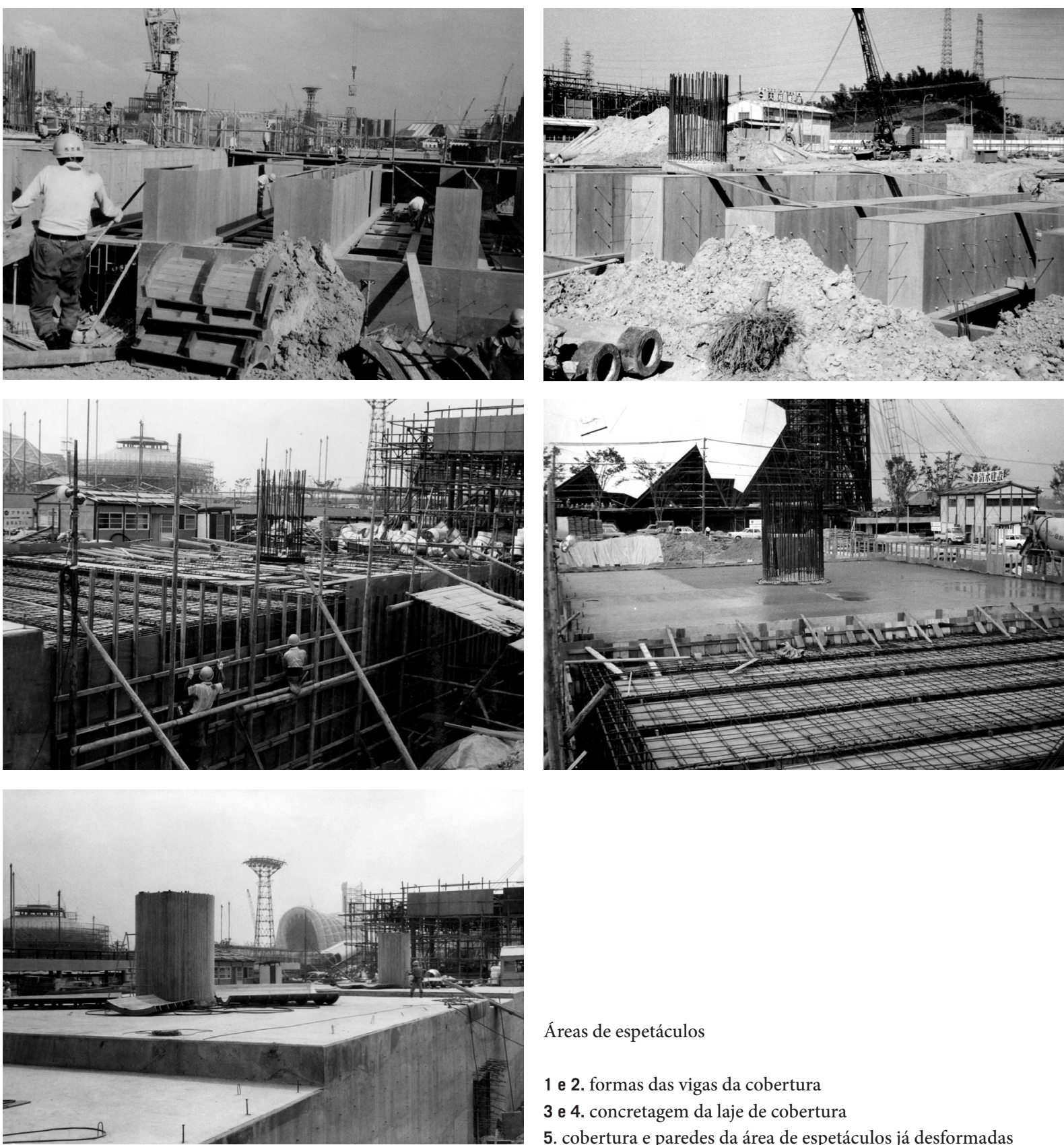

Áreas de espetáculos

1 e 2. formas das vigas da cobertura

3 e 4. concretagem da laje de cobertura

5. cobertura e paredes da área de espetáculos já desformadas 

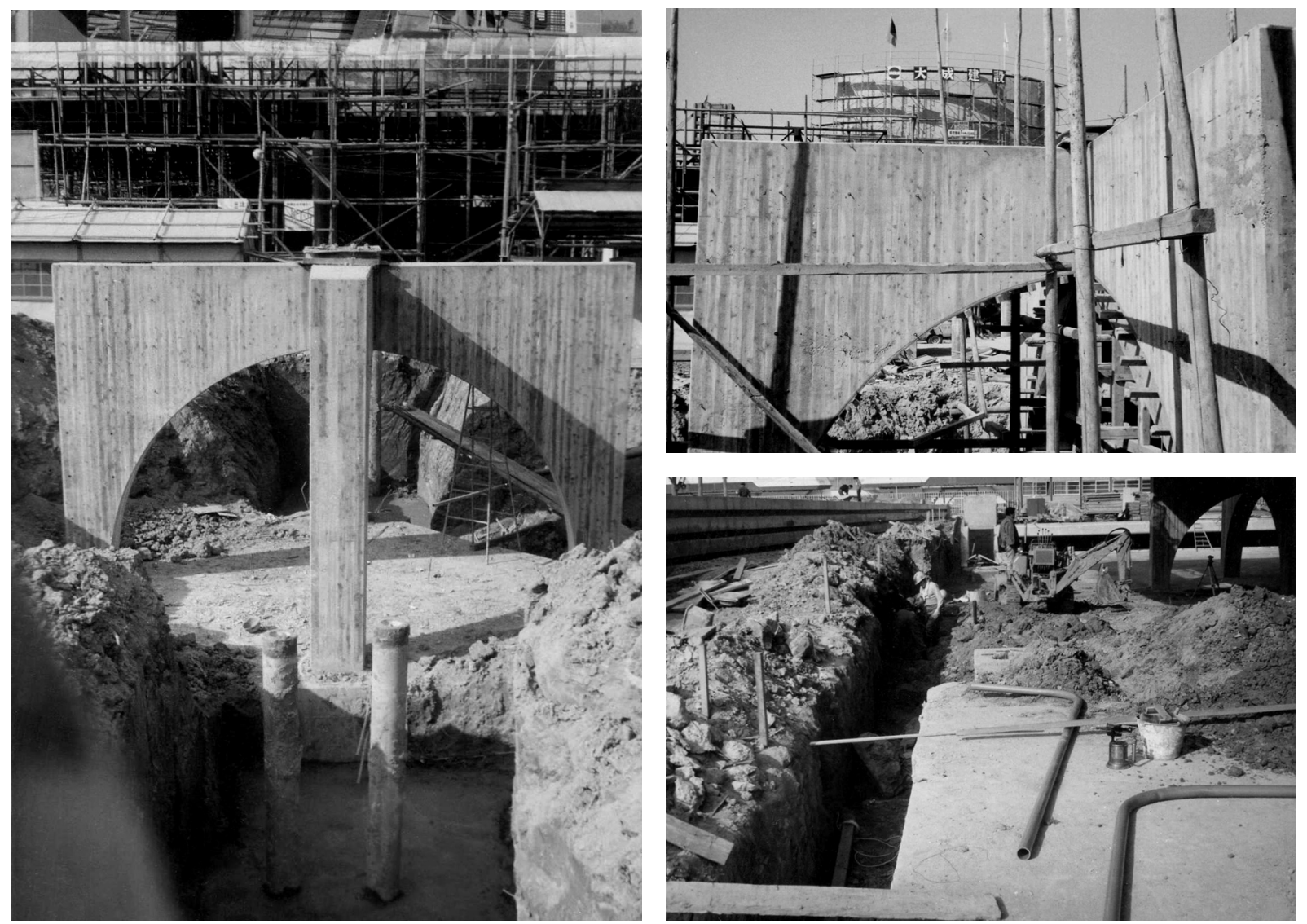

Largo do café

1 e 2. pilar em arco desenformado

3. escavação para ajuste de nível do Largo do Café e construção dos muros de divisa laterais 

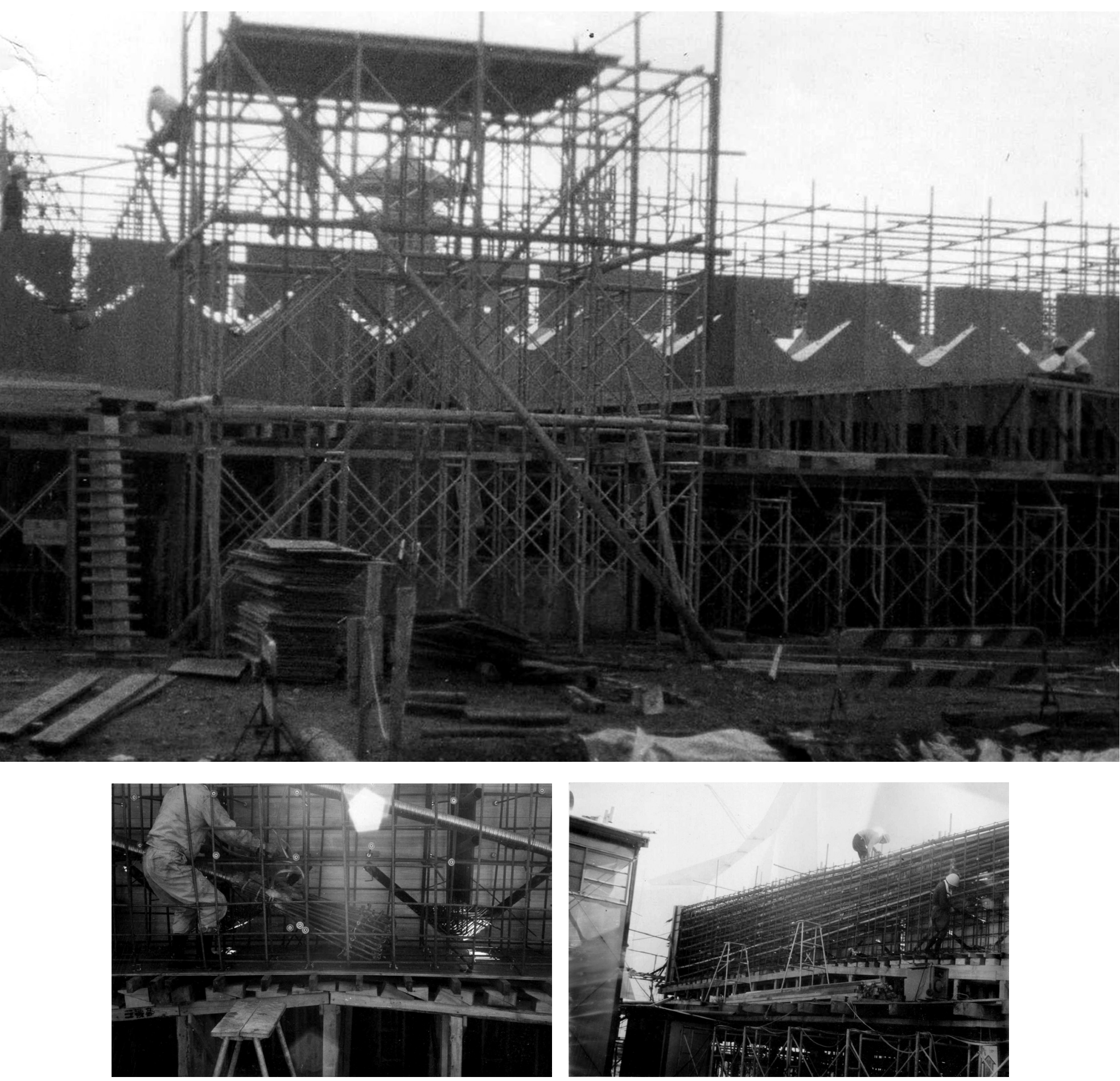

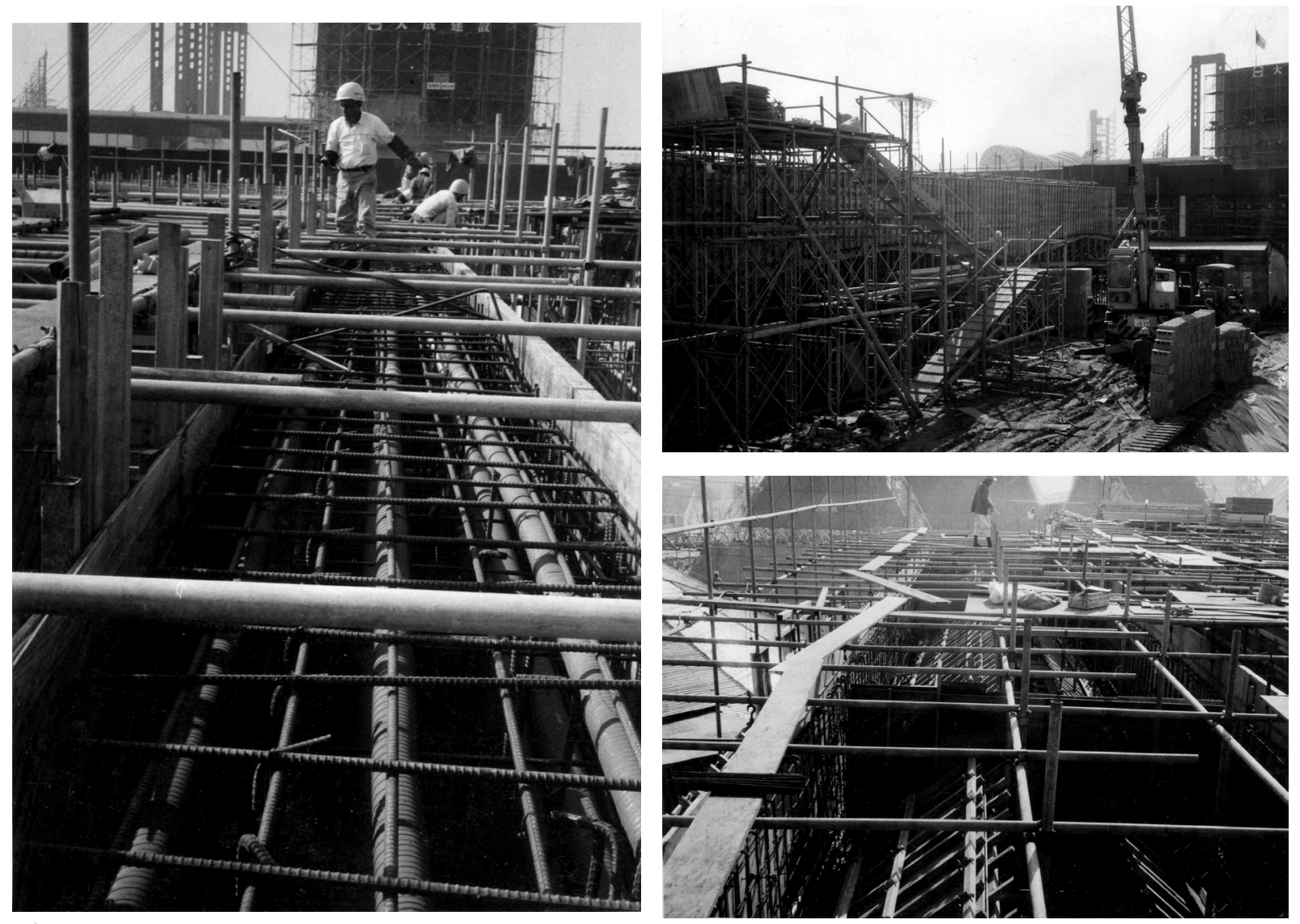

cobertura

1. montagem da forma da viga longitudinal

2. protensão da viga longitudinal

3, 4, 5 e 6. montagem da armação 

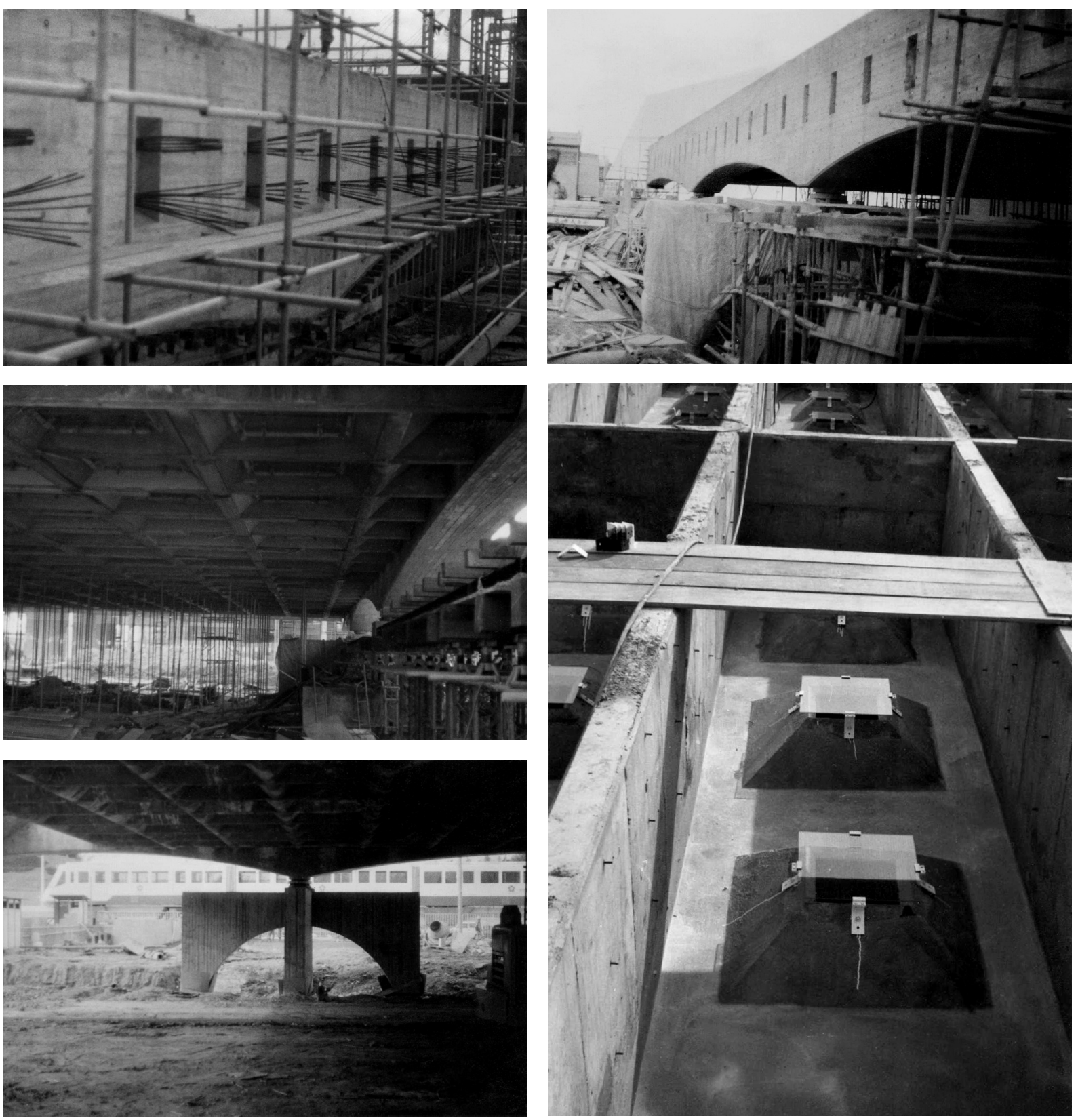

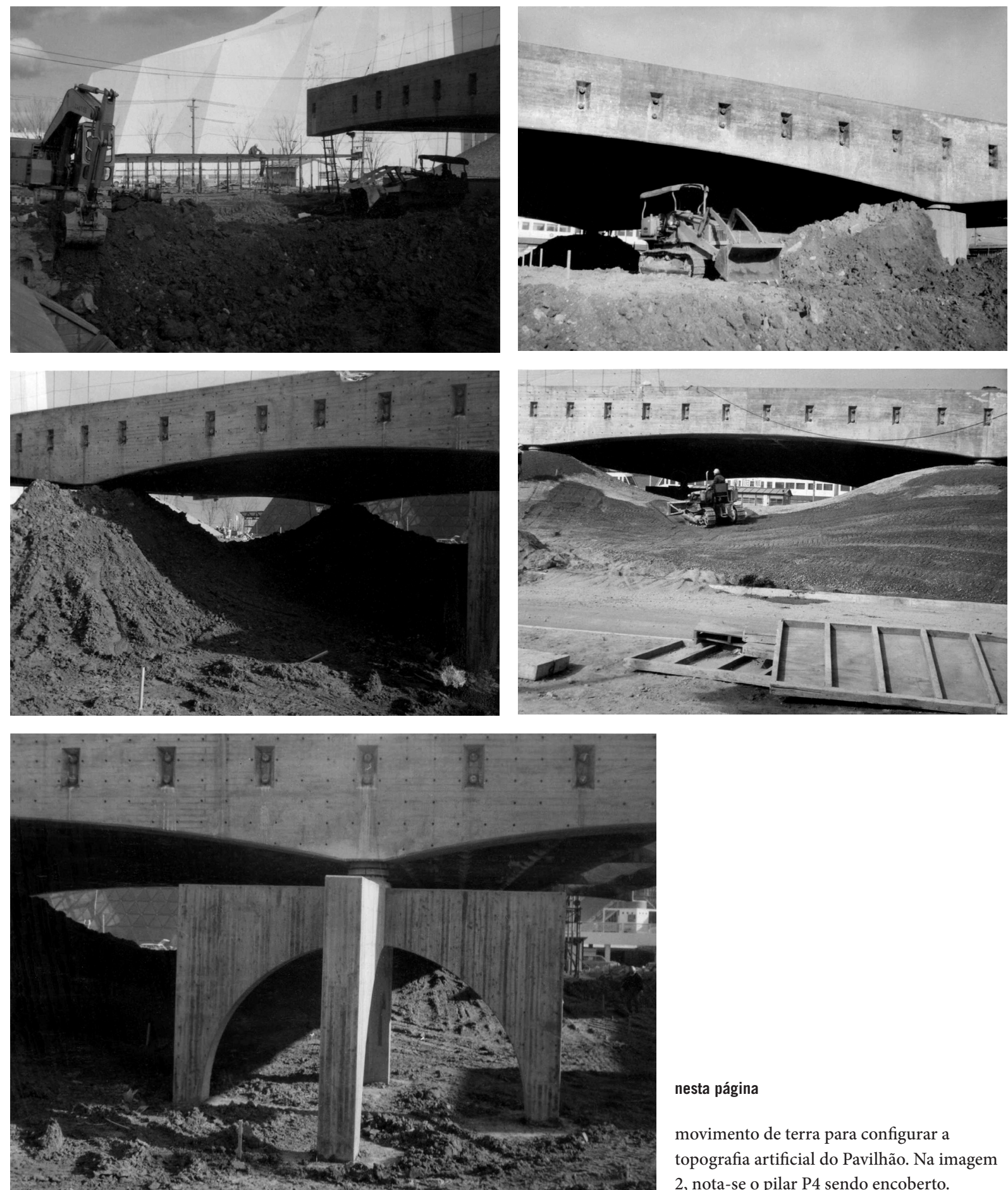

nesta página

movimento de terra para configurar a

topografia artificial do Pavilhão. Na imagem

2, nota-se o pilar P4 sendo encoberto. 


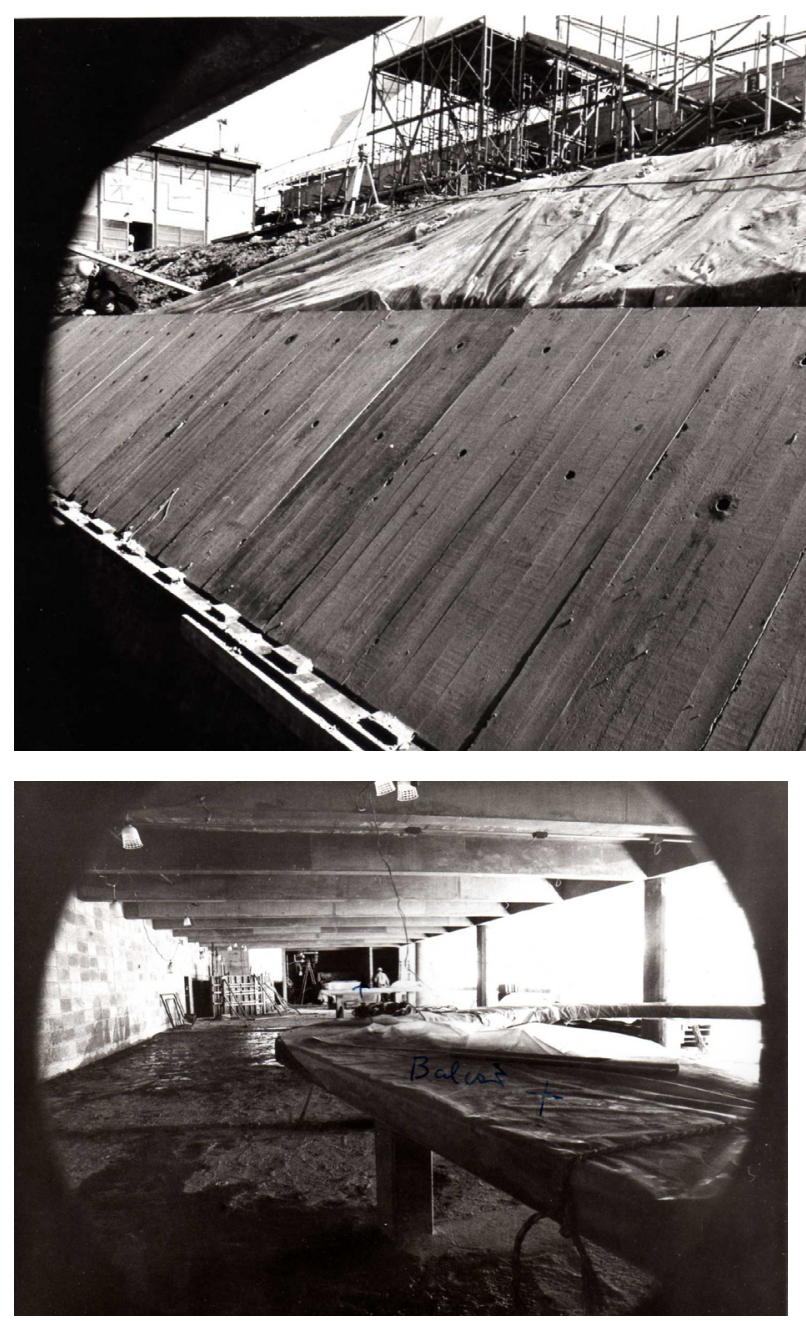

Anexo do Itamaraty

1. muro de arrimo inclinado. Vista de quem está no anexo vendo o Pavilhão, com o olhar na linha do chão como nos croquis

2 e 3. construção dos balcões de atendimento em concreto

4. cobertura e acesso ao anexo vistos de cima da cobertura do Pavilhão 5. instalação do piso em madeira
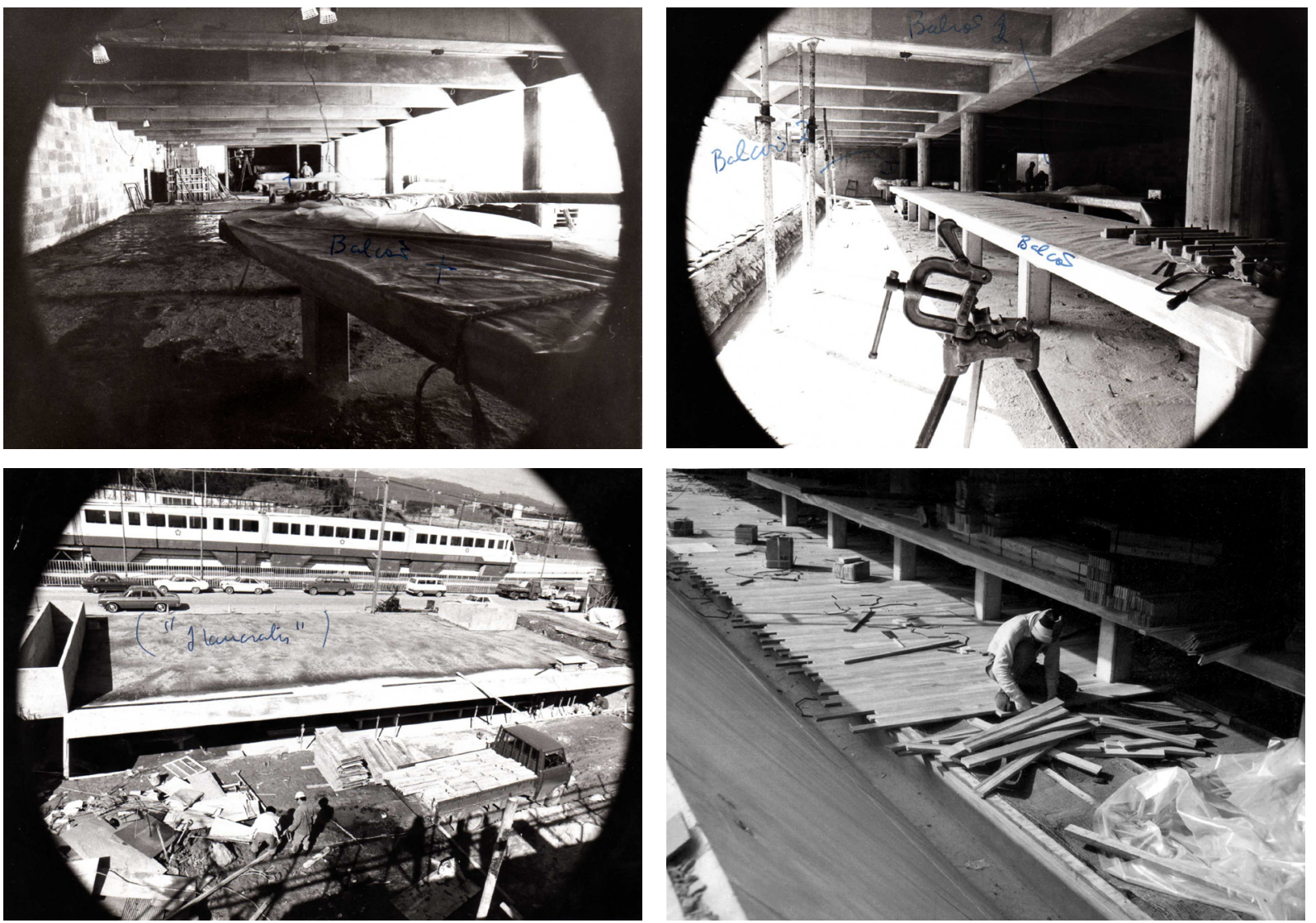

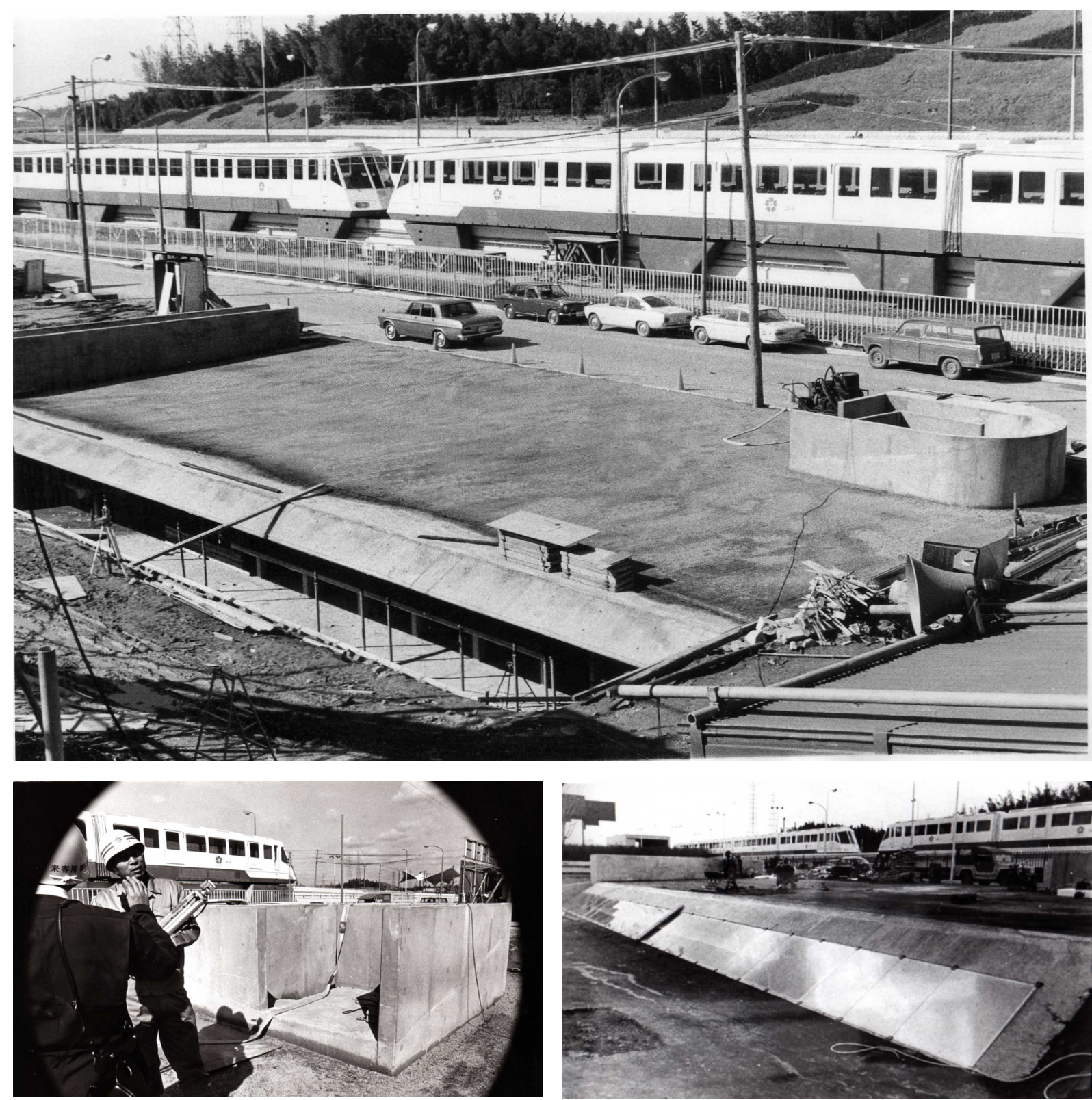

Anexo do Itamaraty

1. cobertura e acessos vistos da cobertura do Pavilhão

2. escada de acesso ao Anexo

3. fechamento sobre o arrimo inclinado, ao nível do piso do Largo do Café
4 a 7. balcões de atendimento em finalização

8. janela no arrimo inclinado, vista pelo lado de dentro do anexo; rebatedor de luz no teto. 

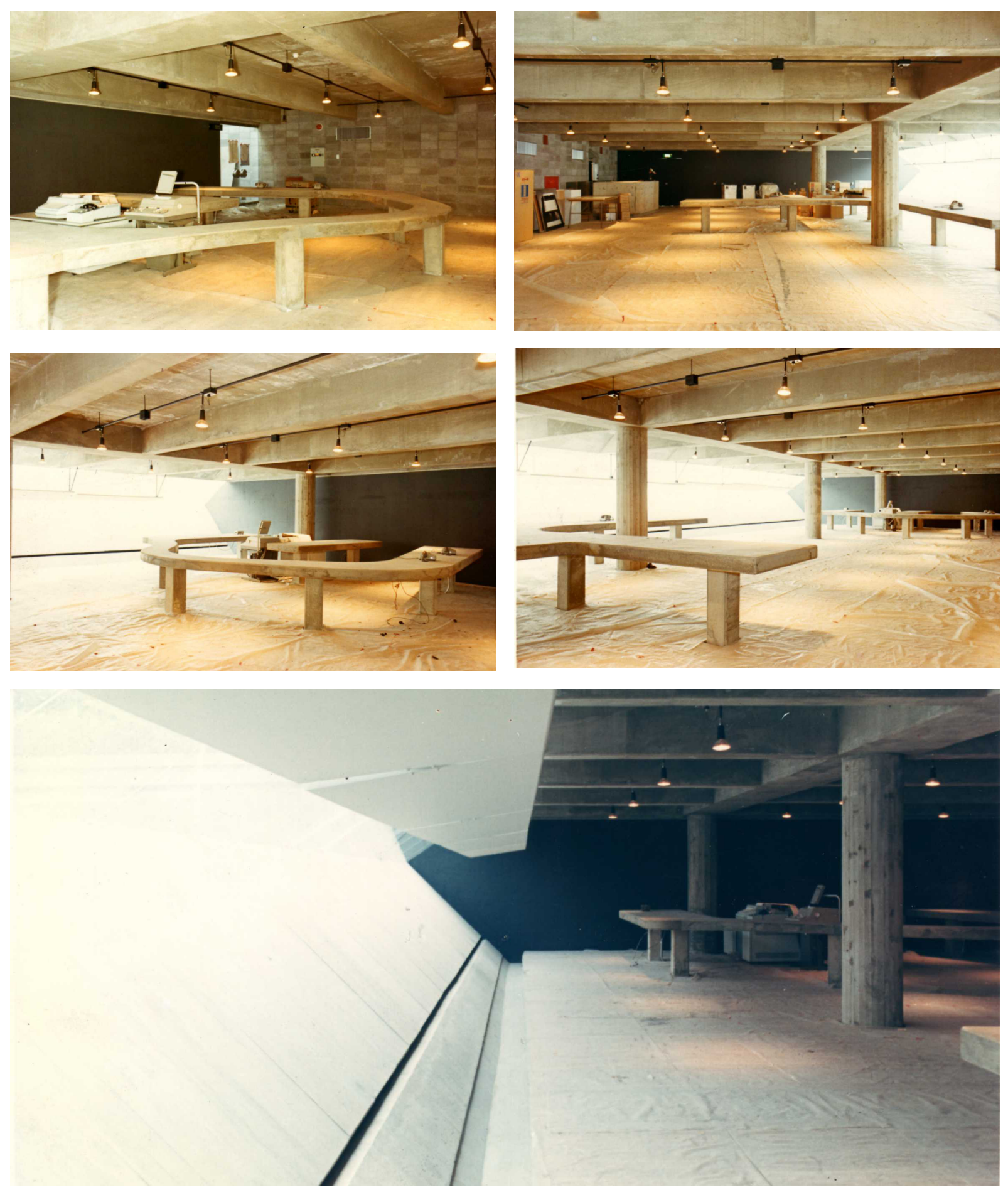


\section{Área de Espetáculos}

1 a 5. vistas da área de espetáculos na fase de finalização e acabamentos

6. escada para o espaço interno sob a cobertura do Pavilhão 7. pintura das vigas da área de espetáculos
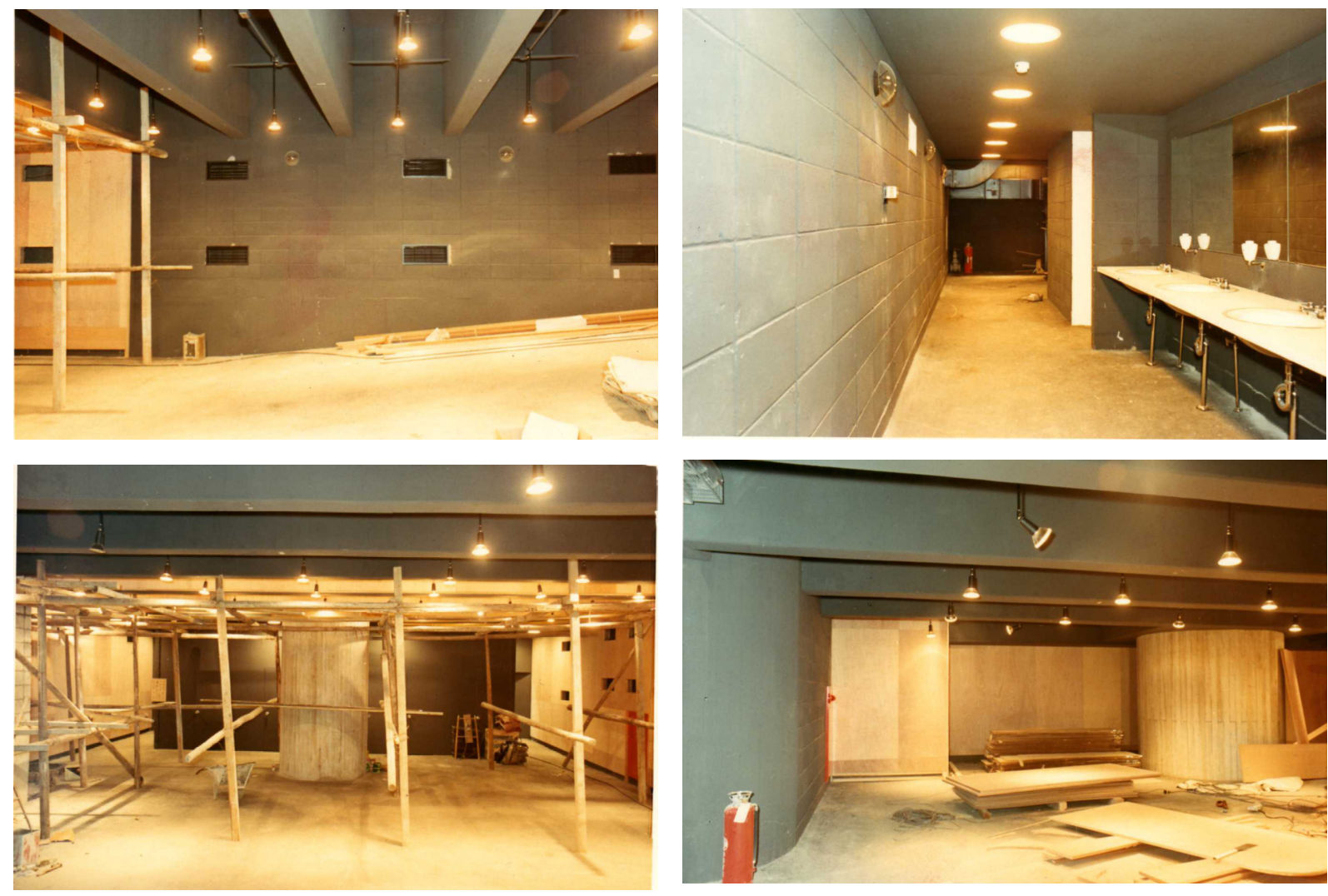


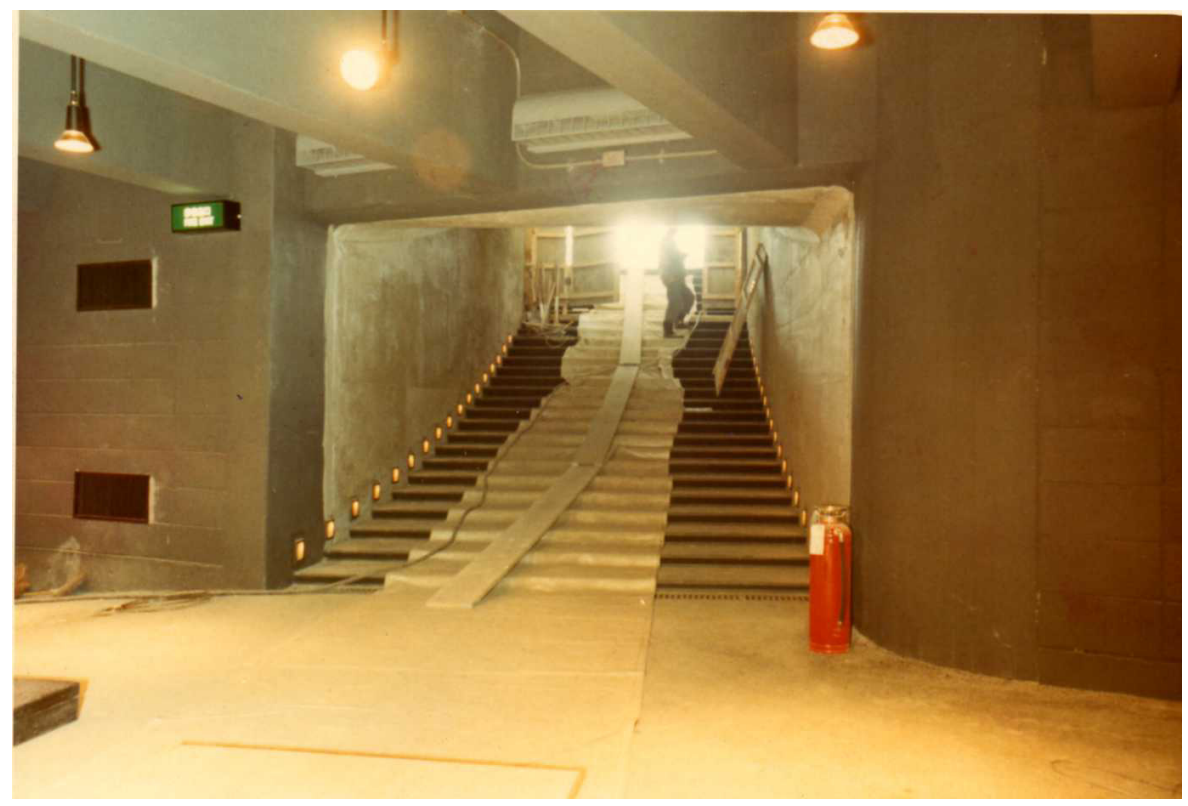

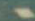
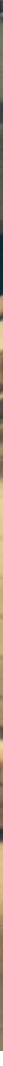

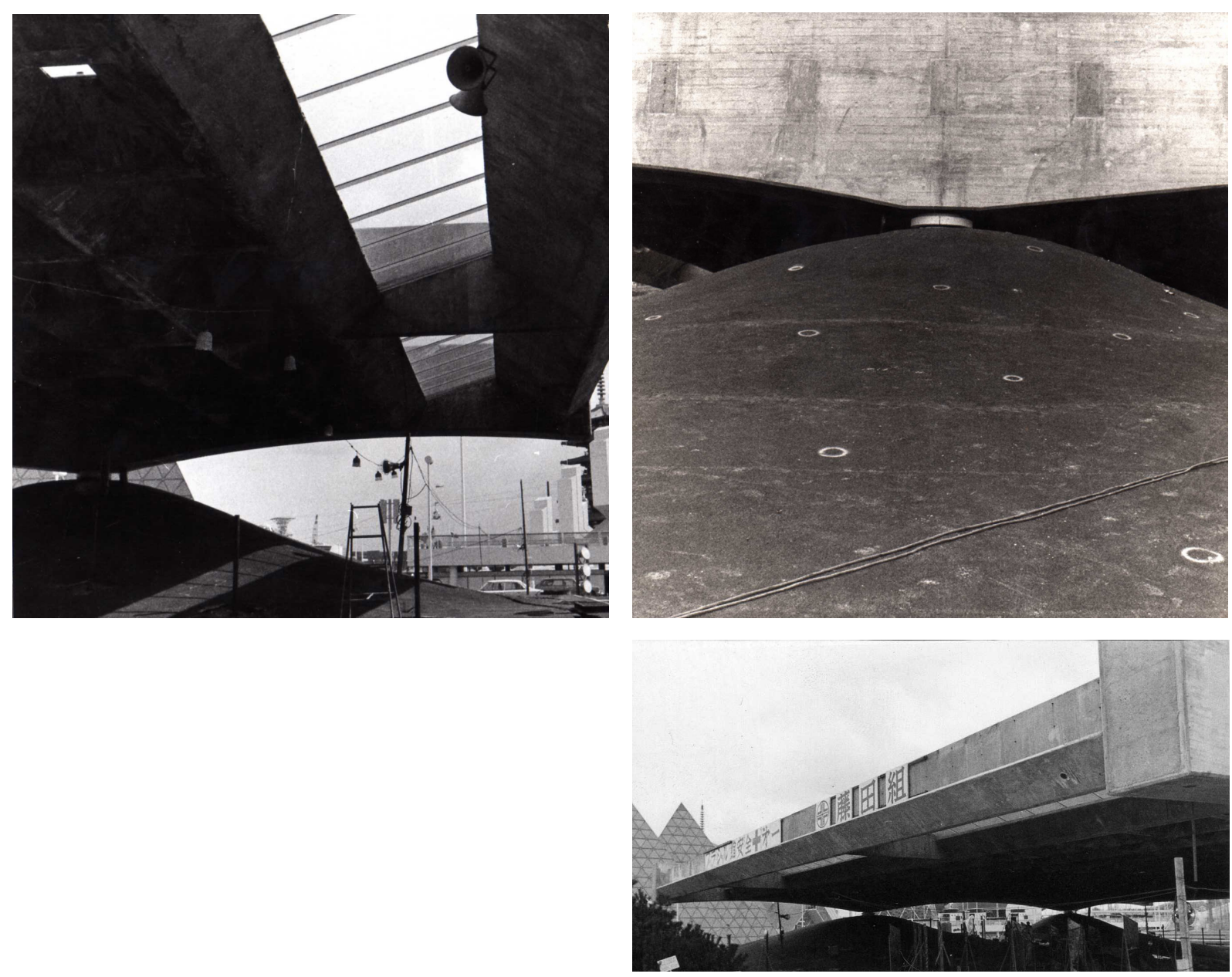

vistas do Pavilhão em finalização / montagem da exposição

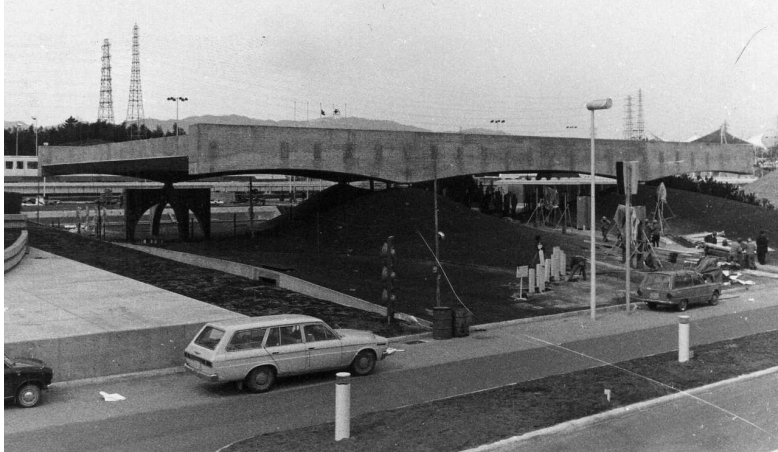




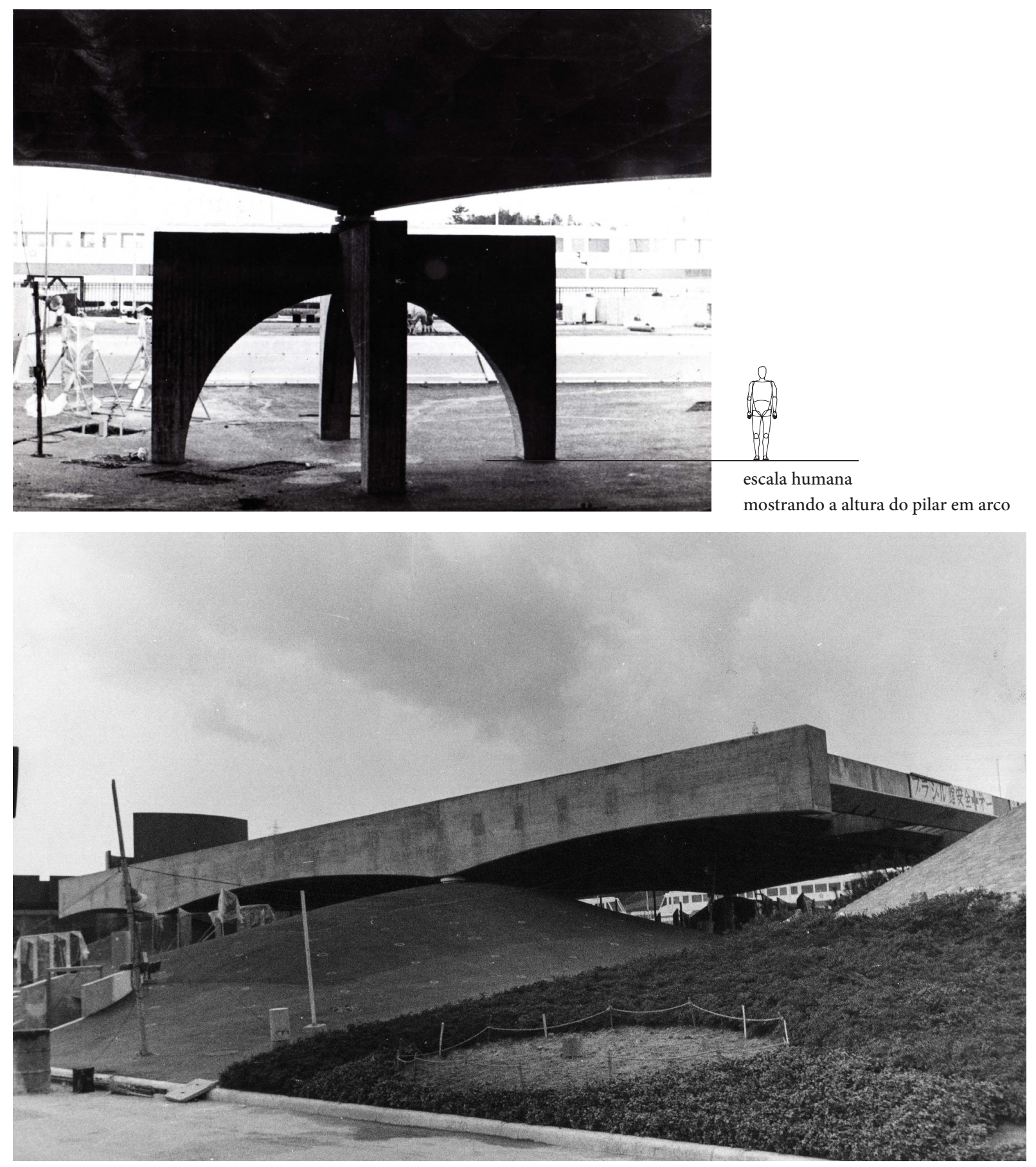




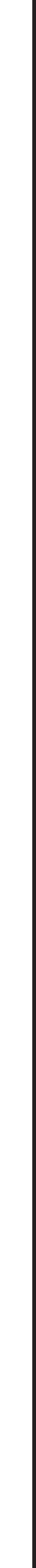

